Gabriela Prioli Della Vedova

A InfluênCia da Repressão Penal sobre o USUÁrio de Crack na busca Pelo Tratamento

DisSERTAÇão DE MESTRAdo

Orientadora: Professora Doutora Irene Batista Muakad

UNIVERSidade de SÃo PaUlo

FACUldade De Direito

São Paulo

2014 
Gabriela Prioli Della Vedova

Departamento de Direito Penal, Medicina Forense e Criminologia

Programa de Pós-GraduAÇÃo EM DiREITO

\section{A InfluênCia da Repressão Penal sobre o USuÁrio de Crack na busca Pelo Tratamento}

Dissertação de Mestrado apresentada à Comissão de Pós-Graduação da Faculdade de Direito da Universidade de São Paulo (CPG/FDUSP) como requisito final para a obtenção do título de mestre, nos termos das diretrizes normativas da Resolução $\mathrm{n}^{\circ} 6.542$, de 18 de abril de 2013.

ORIENTADORA:

Professora Doutora Irene Batista Muakad

Linha de Pesquisa:

Direito Penal e Medicina Forense

Universidade de SÃo PaUlo

FACULDADE DE Direito

São Paulo 


\section{A InfluênCIA da RePressão Penal sobre o USUÁrio de Crack na busca Pelo Tratamento}

Dissertação de Mestrado apresentada à Comissão de Pós-Graduação da Faculdade de Direito da Universidade de São Paulo (CPG/FDUSP) como requisito final para a obtenção do título de mestre, nos termos das diretrizes normativas da Resolução $n^{\circ} 6.542$, de 18 de abril de 2013, sob a orientação da Professora Doutora Irene Batista Muakad.

AUTORA:

Gabriela Prioli Della Vedova

BANCA EXAMINADORA:

Prof(A). Dr(A).

INSTITUIÇÃo:

Prof(A). Dr(A).

INSTITUIÇÃO:

Prof(A). Dr(A).

INSTITUIÇÃO:

São Paulo, 


\section{AgradeCiMENTOS}

Sempre achei que não escreveria agradecimentos. Achei que não escreveria agradecimentos porque não conseguiria produzir nada que não fosse, absolutamente, piegas. No entanto, após esses três anos de pós-graduação e tendo finalmente concluído a dissertação, não posso fazer outra coisa senão escrever agradecimentos e ser, no maior grau possível, piegas. Confesso, foi a minha parte preferida...

Agradeço à minha professora orientadora, a quem nesse momento vou me referir apenas pelo primeiro nome, Irene. Minha querida professora Irene que, na graduação, durante a apresentação de um trabalho sobre drogas, me fez um dos elogios mais bonitos e sinceros que eu já recebi, o que me encorajou a procurá-la para ser minha orientadora nessa nova etapa acadêmica. Professora, pela parceria, pelo companheirismo, por sempre ter me incentivado e acreditado em mim, obrigada.

Ao meu querido e eterno professor, Pedro Aurélio Maringolo, o responsável pela minha inscrição no processo seletivo dessa pós-graduação, meu hoje amigo e parceiro de tantos momentos. Espero ter correspondido às sempre grandes expectativas e espero que os chocolates tenham sido bons, embora obviamente insuficientes para agradecê-lo. Segue aqui o complemento.

Ao Thiago Fidalgo, que me acolheu tão bem e tão prontamente no PROAD, abrindo pra mim as portas da sua casa e viabilizando que esse trabalho fosse feito, revisando incessantemente o meu protocolo de pesquisa, agendando entrevistas, enfim... Thiago, muito obrigada! Além de um parceiro de pesquisa, eu ganhei um amigo.

Estendo os agradecimentos feitos ao Thiago a toda a equipe do PROAD que, como ele, me recebeu tão bem. Me furto a citar os nomes, em virtude do prometido sigilo das entrevistas, mas agradeço a todos vocês, imensamente.

Aos pacientes, os entrevistados e os não entrevistados, que me ensinaram tanto nesse período. O que eles me deram é, sem dúvida, muito inferior ao que eu recebi e engrandeci 
por essa experiência. Vocês me tornarem uma pessoa melhor e nenhuma palavra expressa em uma folha de papel seria capaz de exprimir o quanto eu sou e vou permanecer, pra sempre, grata. Se eu pudesse, como retribuição, entregaria a vocês a liberdade.

Agradeço aos meus amigos queridos, Nathália Perillo, Liliana Carrard, Fúlvia Bolsoni Grola (minha caloura!), Matheus Garcia, Marcela Guimarães, Giovanna Concilio, Luana Korossy, Guilherme Decaro, Eduardo Gomes, Guilherme Cremonesi, Rafael Guaraná, Renata Brandão e Heloisa Estellita. Giovanna, Nathalia, Luana e Lili, que tem mais orgulho do mestrado do que eu e me acham muito mais inteligente e competente do que eu vou conseguir ser na vida. Pela confiança e pelo carinho, sempre, obrigada.

Especialmente, ao meu amigo Giba, meu eterno veterano, sem o qual, sem nenhum resquício de dúvida, esse trabalho não existiria. Foi o Giba quem tomou comigo os cafés inspiradores e quem revisou meu projeto, meu protocolo de pesquisa, minha qualificação e todas (todas!) as versões dessa dissertação. Minuciosamente e com todo o amor e carinho, me ajudou do começo ao fim. Giba, esse trabalho também é seu!

À minha tia Mara, um exemplo de dedicação ao outro, um exemplo de serenidade. Às minhas primas irmãs, Karina, Vanessa e Maira que tornaram a jornada sempre mais fácil, graças aos meus presentes lindos: Felipe, Rodrigo, Alice e Ronney! Vanessa, obrigada pela melhor notícia de virada de ano!

À minha tia Ruth, por todo o amor e admiração incondicionais que ela sempre me dedicou, a vida toda.

Ao Antonio, que me acompanhou nessa jornada, do começo ao fim.

E por fim, às pessoas mais importantes da minha vida...

Ao Rafa, meu irmão amado e brilhante, que me ensina todos os dias, com seu jeito peculiar e evoluído de viver a vida, que tantas vezes discutiu comigo o tema desse trabalho, opinando, e, mesmo num domingo à tarde, revisando o último capítulo. 
Ao Paulo, meu querido Pailo, que sem concordar comigo, fortaleceu meus argumentos! A vida, generosa, me deu a oportunidade de ter dois pais, e eu, esperta que sou, tenho muito dos dois. Aproveito então, para, no mesmo parágrafo e imaginando que, de algum lugar, ele se orgulha de mim, agradecer ao meu pai.

O maior agradecimento só poderia ser para minha mãe, sem dúvida a mulher mais incrível, forte, batalhadora, inteligente, amorosa, parceira e generosa que existe. Pode parecer lugar comum, mas eu tenho a melhor mãe do mundo. A mãe que leu os livros chatos, para que eu nunca desgostasse da leitura; a mãe que me deu cobertura para dizer o que eu quisesse, pra quem eu quisesse, desde que eu nunca desrespeitasse ninguém; a mãe que me ensinou a questionar, sempre, mesmo que isso significasse questionamentos dirigidos a ela; a mãe que transformou em felicidade mesmo os momentos mais tristes; que me deu tudo que podia, até quando, eventualmente, não podia. À minha melhor amiga. Repito aqui o que sempre disse, desde criança: se algum dia eu for metade do que você é pra mim, eu serei plenamente satisfeita. Muito obrigada, mais do que por esse trabalho, por eu ser a pessoa que sou.

Muito obrigada a todos vocês! 


\title{
A InfluênCia da Repressão Penal sobre o Usuário de Crack na BUSCA PELO TRATAMENTO
}

\begin{abstract}
RESUMO
O presente trabalho analisa o impacto do exercício da repressão penal sobre os usuários de crack na busca pelo tratamento, avaliando a coerência entre os fins declarados pela atual política de drogas e os meios previstos em lei para sua consecução. O estudo se desenvolveu por meio de pesquisa qualitativa com seres humanos operada através de entrevistas com usuários e ex-usuários de crack em tratamento, bem como com os profissionais da equipe multidisciplinar do local de tratamento.
\end{abstract}

Palavras-chave: Direito Penal - Política de Drogas - Drogas - Crack. 


\title{
The Influence Of Criminal RePression On Crack USERS SeEking TREATMENT
}

\begin{abstract}
This paper analyzes the impact of criminal repression on crack users seeking treatment, evaluating the coherence between the purposes declared by the current drug policy and the means provided by law for its achievement. This paper was conducted by means of a qualitative research with humans beings, operated through interviews with crack users and former users in treatment, as well as with professionals in the multidisciplinary team from the treatment site.
\end{abstract}

Key words: Criminal Law - Drug Policy - Drugs - Crack. 
"O serviço dos narcóticos na luta pela felicidade e no afastamento da miséria é tão valorizado como benefício, que tanto indivíduos quanto povos lhes reservaram um sólido lugar na sua economia libidinal. A eles não se deve só o ganho imediato de prazer, mas também de parcela muito desejada de independência em relação ao mundo externo. Sabe-se que com a ajuda do "afasta tristeza" podemos nos subtrair à pressão da realidade a qualquer momento e encontrar refúgio num mundo próprio que tenha melhores condições de sensibilidade”

Sigmund Freud, em O Mal - Estar na Civilização ${ }^{1}$

${ }^{1}$ FREUD, Sigmund. O Mal-estar na civilização. São Paulo: Penguin e Companhia das Letras, 2011. p. 22. 


\section{SUMÁRIO}

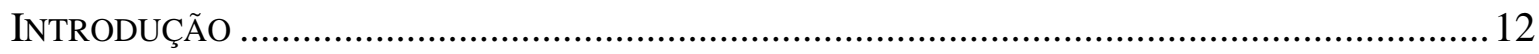

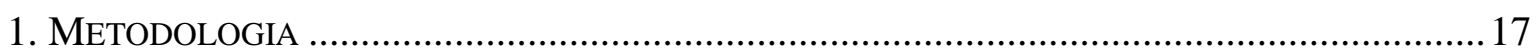

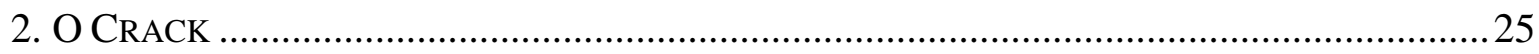

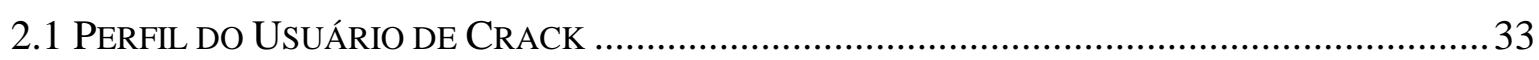

2.2 CRACK: O INIMIGO PÚBLICO NÚMERO UM ............................................................ 40

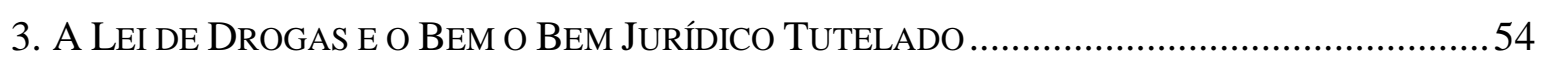

3.1 A EvoluÇÃo da CRIMINALIZAÇÃo do USUÁRIO DE DroGaS ......................................59

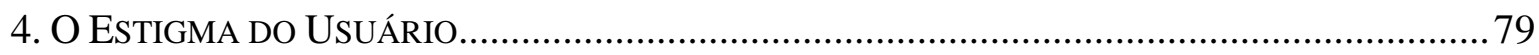

5. A Repressão Penal sobre o Usuário de Drogas como Fator de AproximaÇão/Afastamento do Tratamento. A CoerênCIA EnTRE os Fins Almejados PELA PolíticA DE Drogas E SUA APLICAÇão PRÁtiCA. .................................................. 102

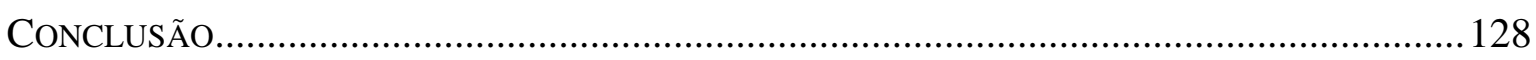

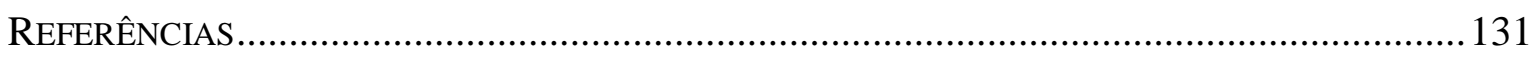

APÊNDICE 1 - ROTEIRO DAS ENTREVISTAS COM USUÁRIOS............................................... 143

APÊNDICE 2 - RotEIRO DAS ENTREVISTAS COM PROFISSIONAIS ....................................... 144

APÊNDICE 3 - TRANSCRIÇÃO DAS ENTREVISTAS COM USUÁRIOS ....................................... 145

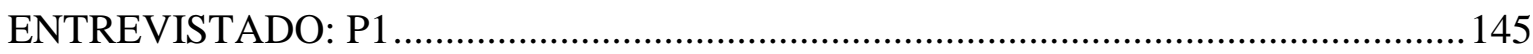

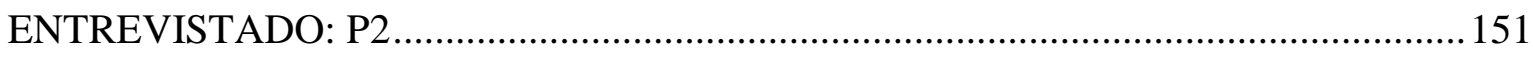

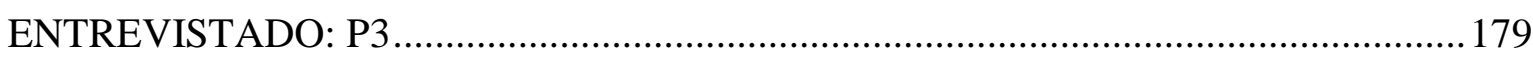

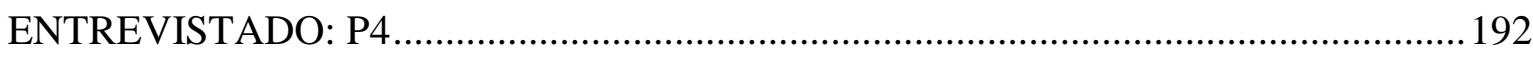

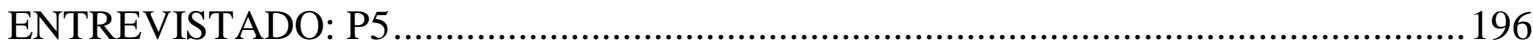

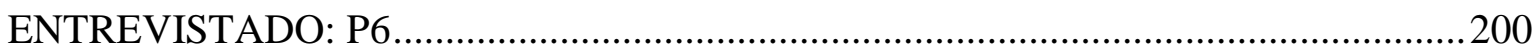

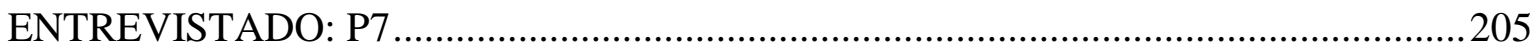

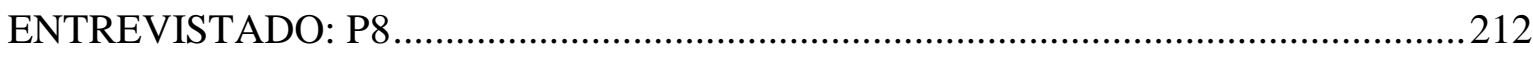

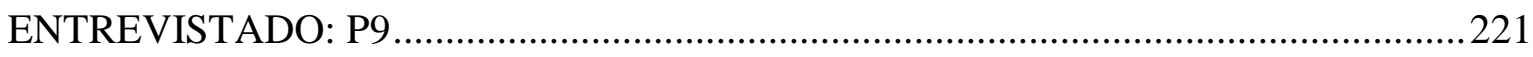

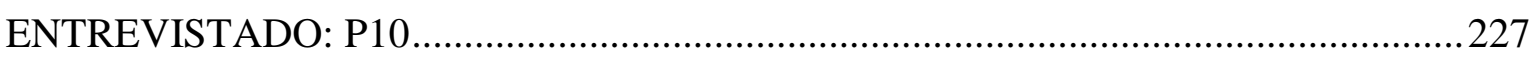

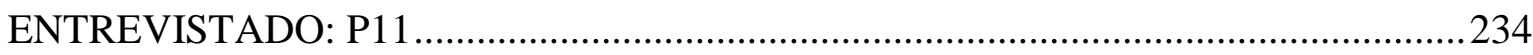

APÊNDICE 4 - TRANSCRIÇÃO DAS ENTREVISTAS COM PROFISSIONAIS DA EQUIPE FIXA ..... 246

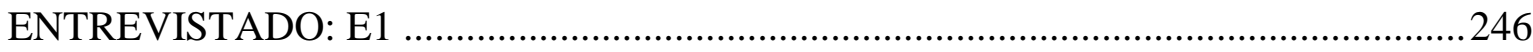

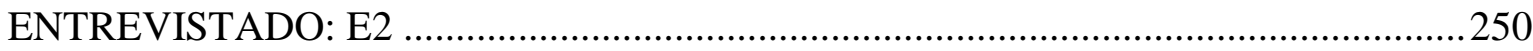

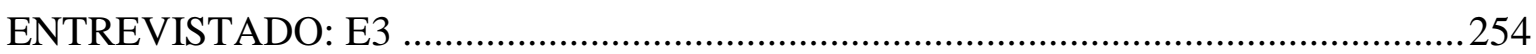




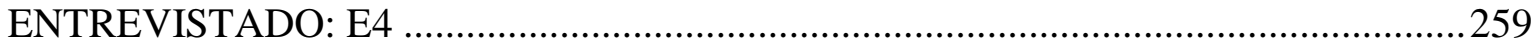

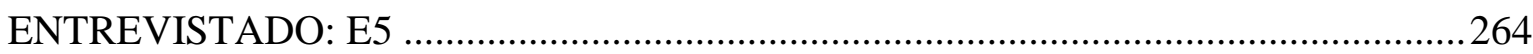

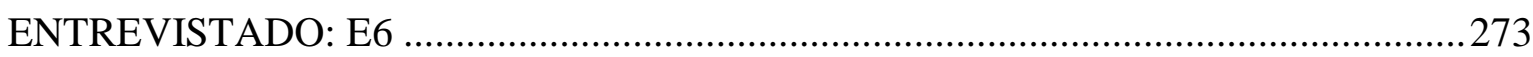

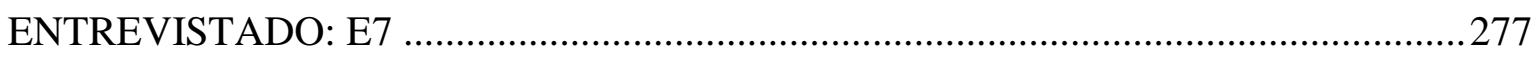

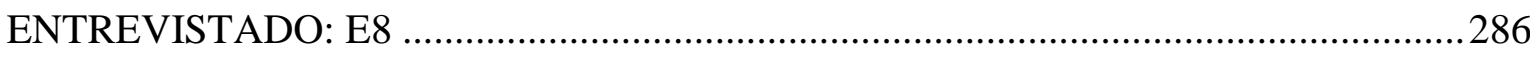

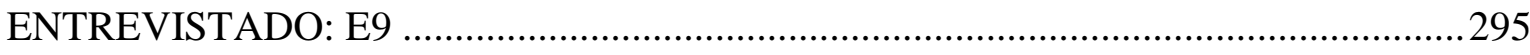

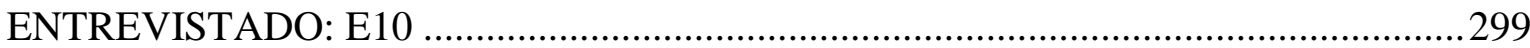

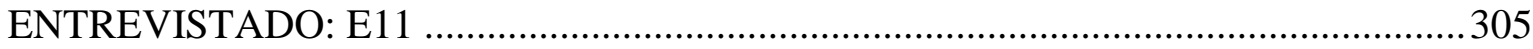

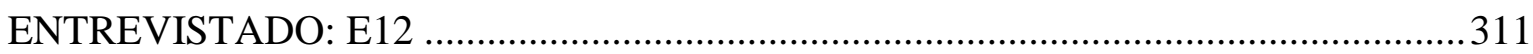

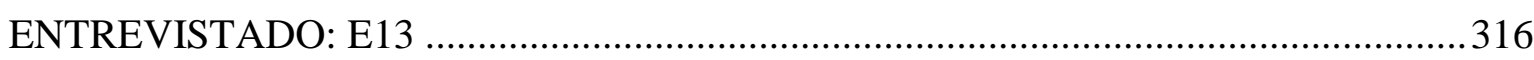

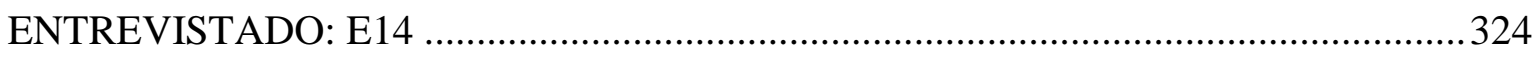

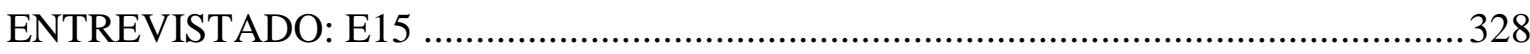

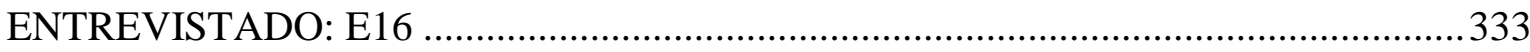

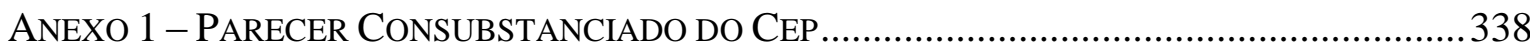




\section{INTRODUÇÃO}

Esta dissertação de mestrado apresenta-se como um dos requisitos para a obtenção do título de mestre e dá cumprimento à última fase das etapas da pesquisa stricto sensu no âmbito do programa de pós-graduação da Faculdade de Direito da Universidade de São Paulo - USP.

O tema de pesquisa é a influência exercida pela repressão penal sobre o usuário de crack na busca e adesão ao tratamento. Buscou-se compreender se a política criminal que mantém classificada como crime a conduta de portar drogas para seu consumo pessoal e, portanto, viabiliza o exercício da violência legal contra o usuário, é fator que enseja reflexão e/ou aproxima o usuário dos locais de tratamento ou se ao contrário, afasta o indivíduo das opções de tratamento, entendido como qualquer ação de cuidado que viabilize a melhora da qualidade na relação com a substância.

O tema do trabalho ganha relevância à medida que o discurso político criminal que vige atualmente no país traça como objetivos a) a prevenção do uso indevido, a atenção e a reinserção social de usuários e dependentes de drogas e, b) a repressão da produção não autorizada e do tráfico ilícito de drogas (artigo $3^{\circ}$ da Lei $n^{\circ} 11.343 / 2006$ ), mas mantém a criminalização dos usuários por meio do tipo penal inscrito no artigo 28 do mesmo diploma legal, ensejando também que ações repressivas sejam direcionadas a esses indivíduos.

Questiona-se: existe coerência entre uma política pública que dirija, aos mesmos indivíduos, ações de atenção e repressivas?

Nesse ponto, vale uma consideração sobre o porquê de terem sido objeto da pesquisa somente os usuários de crack, já que substância é tão ilícita quanto todas as outras previstas na Portaria do Ministério da Saúde que complementa os dispositivos inseridos na Lei $\mathrm{n}^{\circ}$ 11.343/06. O crack, por suas características de uso e potencial lesivo, tem sido tratado de forma absolutamente distinta das demais substâncias ilícitas pelos programas governamentais. É em relação a essa droga que fica cada vez mais patente o discurso da possibilidade de "cura" em contraponto a ações essencialmente violentas e segregacionistas que são dirigidas a esses usuários. Pela clareza do convívio entre as duas frentes de ação, 
saúde e direito penal ${ }^{2}$, é que os usuários dessa substância, em corte específico da região metropolitana da cidade de São Paulo, foram os indivíduos estudados pelo presente trabalho.

A escolha do tema da dissertação de mestrado sofreu alterações significativas durante o período de curso das disciplinas de créditos obrigatórios. As drogas sempre foram assunto principal e o usuário, como parte mais frágil da complexa realidade dessa relação, o foco principal da preocupação do estudo, mas num primeiro momento, o objetivo do trabalho se circunscrevia a uma análise teórica da política de drogas adotada pelo Brasil.

Considerando a formação exclusivamente jurídica da pesquisadora, muito embora houvesse o interesse pelos aspectos médicos relacionados ao uso das drogas, razão pela qual a busca de uma professora orientadora se deu na Medicina Legal, pretendia-se um trabalho que confrontasse os motivos médicos e sociais indicados como ensejadores da opção política e legislativa em matéria de drogas, com a realidade dos estudos recentes produzidos nas duas áreas. A ideia da pesquisa empírica ainda não havia surgido.

Após um primeiro semestre de disciplinas cursadas na Faculdade de Direito, a opção por disciplinas no Departamento de Psiquiatria da Faculdade de Medicina da Universidade de São Paulo deu novo rumo à pesquisa. Em contato com os profissionais da área especialmente interessados no tema, bem como com os estudos produzidos recentemente, um aspecto ficou particularmente claro: a distância entre os conhecimentos produzidos nas distintas áreas do conhecimento e a aparente comunicação ruidosa travada pelos profissionais debruçados na questão das drogas e, mais especificamente, do crack. Em termos menos formais, parece que os profissionais falam línguas diferentes. Questões absolutamente simples para um profissional da área jurídica são recebidas com espanto pelos profissionais da área da saúde.

Os profissionais da saúde, no geral, trabalham com um conhecimento superficial do direito, e os profissionais do direito, também generalizando, com um conhecimento superficial da saúde. É claro que é de se esperar que cada profissional trabalhe concentrado

\footnotetext{
2 Os vocábulos "direito penal" e "saúde" serão aplicados em sua ampla concepção, de modo que, com a utilização do termo direito penal se possa entender criminologia e política criminal, enquanto saúde compreenderá medicina, terapia ocupacional, psicologia, assistência social, redução de danos e todas as áreas relacionadas à atenção aos usuários de drogas.
} 
na sua área, mas, praticamente, parece proveitoso, senão necessário, que em assuntos cuja relação é intrínseca e interdisciplinar, como é o das drogas, exista um maior intercâmbio de informações.

É esse intercâmbio que parece fundamental na discussão das políticas públicas direcionadas ao usuário das substâncias psicoativas ao passo que a repressão penal não é ou não deveria ser -o único meio de contato entre o Estado e esses indivíduos. Em outras palavras, para que se possa concluir pela melhor abordagem do usuário, tendo em mente os objetivos a ele relacionados, os profissionais da área médica e os profissionais da área jurídica precisam conversar mais e conversar de uma forma que o discurso de cada um deles possa ser compreensível para a outra parte, para que assim possam propor soluções coerentes para as políticas públicas direcionadas ao tema.

Essa tendência de troca de informações já pôde ser verificada, por exemplo, no Curso de Extensão, em modalidade ensino a distância, realizado pela Secretaria Nacional Sobre Drogas - SENAD, em parceria com as Universidades de Direito e Medicina da USP, realizado no primeiro semestre de 2012. O curso, que reunia "tutores" de ambas as áreas do conhecimento, foi direcionado ao aperfeiçoamento dos operadores do direito nos Juizados Especiais Criminais, que cuidam da questão do usuário inserido no sistema penal pela aplicação das sanções previstas no artigo 28 da Lei n ${ }^{\circ} 11.343 / 06$ ou da transação penal.

O discurso ensejador da referida opção de ensino foi que de nada adianta que a Lei preveja para os usuários medidas diferentes da pena restritiva de liberdade e reconheça a redução de danos como um dos objetivos a serem alcançados pela nova política criminal se a totalidade dos operadores do direito não estiver preparada para entender a aplicação dessas medidas, bem como a sua utilidade.

Pois bem. Para responder à questão suscitada, o estudo foi desenvolvido de forma eminentemente empírica, através de entrevistas semiestruturadas realizadas com usuários de crack e profissionais do serviço de saúde no qual essas pessoas se encontravam em tratamento. As considerações sobre a formação da amostra, coleta e análise dos dados será abordada no capítulo destinado à metodologia. 
Essencialmente interdisciplinar, o trabalho apresenta em seus capítulos iniciais, aportes teóricos considerados relevantes para permitir a compreensão da pesquisa por profissionais distintos.

O primeiro capítulo é dedicado à metodologia. O segundo capítulo, permanecendo fiel à valorização dos dados empíricos sugerida pelo presente trabalho, analisa, através de dados coletados em pesquisas, o surgimento do crack no Brasil, a evolução do consumo, o perfil de seus usuários e os discursos específicos de combate a droga adotados recentemente pelo poder público.

O terceiro capítulo, mais ligado aos conceitos das ciências jurídicas, tece considerações sobre a Política de Drogas que vige atualmente no Brasil. A Lei nº 11.343/06 e seus avanços e retrocessos. A manutenção da lógica proibicionista aliada ao reconhecimento do usuário como sujeito de direitos que se traduz no objetivo declarado de sua reinserção social, afastando-o, em tese, de uma política que o relega a repressão pura e simples em contraposição.

No quarto capítulo terão lugar considerações de ordem criminológica sobre a seletividade do sistema penal e o estigma carregado pelos usuários que, além de suportarem o peso moral de serem drogados, permanecem detentores da pecha de criminoso.

Embora os assuntos formadores desse referencial teórico tenham sido definidos $a$ priori, a escolha não foi definitiva e sofreu alterações significativas pelo rumo tomado pela pesquisa após a finalização das entrevistas. Disso se pode depreender que o conhecimento prévio proporcionado pela teoria não guiou a pesquisadora apenas pelos caminhos já conhecidos e permitiu a descoberta de novas realidades, garantindo que o resultado da pesquisa reflita a visão dos entrevistados.

Por fim, o quinto capítulo conterá a análise das entrevistas, verificando a possibilidade de convívio coerente entre os objetivos declarados da Política de Drogas, quais sejam, a atenção e reinserção social do usuário e a manutenção da lógica punitiva que viabiliza o exercício da violência legal monopolizada pelo Estado contra esses cidadãos. 
Muito embora a análise maciça das entrevistas para solucionar a questão que serve de tema à presente pesquisa seja apresentada apenas no quinto capítulo, para ilustrar as questões postas nos capítulos introdutórios, trechos das entrevistas foram citados no decorrer do texto, garantindo que a opinião dos entrevistados servisse para corroborar ou negar a teoria.

Considerando que as conclusões obtidas por meio de pesquisa de natureza eminentemente qualitativa foi reservada a amostra significa apenas no universo em que foi realizada, qual seja, o serviço do qual faziam parte os pacientes e os profissionais entrevistados, seus resultados não comportam transposição para universos maiores, pelo que a presente análise pode servir de base para novas pesquisas relacionadas ao tema com amostras significativas que possam direcionar as opções de política criminal. 


\section{Metodologia}

Existiria uma possibilidade concreta de tratarmos de uma realidade da qual nós próprios, enquanto seres humanos, somos agentes? Essa ordem de conhecimento não escaparia radicalmente a toda possibilidade de objetivação?

$\mathrm{E}$, será que buscando a objetivação própria das ciências naturais, não estaríamos descaracterizando o que há de essencial nos fenômenos e processos sociais, ou seja, o profundo sentido dado pela subjetividade? ${ }^{3}$

A pesquisa científica caracteriza-se pelo esforço sistemático de - usando critérios claros, explícitos e estruturados, como teoria, método e linguagem adequada - explicar ou compreender os dados encontrados e, eventualmente, orientar a natureza ou as atividades humanas ${ }^{4}$. A cientificidade, portanto, tem que ser pensada como uma ideia reguladora de alta abstração, e não como sinônimo de modelos e normas a serem seguidos ${ }^{5}$.

A metodologia pode ser entendida como o caminho seguido pelo pensamento na abordagem da realidade ${ }^{6}$, "o método é a alma da teoria"”. Isso não significa dizer, no entanto, que as regras metodológicas devam ser, sempre, seguidas à risca. Não raras vezes, o mundo experimentado exige do observador que crie novas abordagens. "o endeusamento das técnicas produz um formalismo árido ou respostas estereotipadas. Seu desprezo, ao contrário, leva ao empirismo sempre ilusório em suas conclusões, ou a especulações abstratas e estéreis." 8

A metodologia de pesquisa qualitativa surge, historicamente, como uma reação das ciências sociais ao modelo positivista caracterizado por uma visão determinista da sociedade que a entendia como fenômeno externo ao ser humano, que poderia ser explicado através de leis universais e imutáveis às quais se pode chegar através dos métodos de pesquisa. $\mathrm{Na}$ pesquisa qualitativa, o que se pretende é estudar os significados atribuídos pelos indivíduos a determinadas situações.

\footnotetext{
${ }^{3}$ MINAYO, Maria Cecília de Souza (Org.). Pesquisa Social: Teoria, método e criatividade. 30 ed. Petrópolis/RJ: Vozes, 2011. p.15.

${ }^{4}$ CHIZZOTTI, Antonio. Pesquisa Qualitativa em Ciências Humanas e Sociais. 4 ed. Petrópolis/RJ: Editora Vozes, 2011. p.20.

${ }^{5}$ MINAYO, Maria Cecília de Souza (Org.). Op. Cit., p. 10.

${ }^{6}$ Ibidem, p.13

${ }^{7}$ Ibidem, p.14

${ }^{8}$ Ibidem, p. 15
} 


\begin{abstract}
Se o pesquisador supõe que o mundo deriva da compreensão que as pessoas constroem no contato com a realidade nas diferentes interações humanas e sociais, será necessário encontrar fundamentos para uma análise e para a interpretação do fato que revele o significado atribuído a esses fatos pelas pessoas que partilham dele. ${ }^{9}$
\end{abstract}

Como compreender os efeitos que a possibilidade de uma abordagem repressora e impositiva tem sobre os usuários de drogas sem o contato direto com esses sujeitos? Qualquer análise que pretendesse chegar à conclusão sobre o impacto da criminalização sobre o usuário na busca pelo tratamento - aí compreendidas todas as ações capazes de reduzir os custos de seu consumo - ignorando as impressões do usuário sobre as situações por ele vivenciadas, seria mera suposição.

Não obstante a pesquisa qualitativa tenha seu nascimento vinculado às ciências sociais, pela mudança significativa no modo de compreender o fenômeno estudado em suas várias faceta, esse método de pesquisa em que o pesquisador vai até o sujeito de investigação e busca suas percepções particulares acerca do fenômeno em estudo não é muito comum no Direito.

$\mathrm{Na}$ apresentação de sua tese de livre docência o professor Sérgio Salomão Shecaira declara já ter sido inovadora a inserção em sua dissertação de mestrado de um capítulo dedicado à pesquisa empírica ${ }^{10} \mathrm{e}$, de fato, até a conclusão desta dissertação não havia, na biblioteca da Faculdade de Direito da Universidade de São Paulo, qualquer título dedicado à pesquisa qualitativa.

Também não há um Comitê de Ética em Pesquisa na Faculdade de Direito da Universidade de São Paulo, pelo que, após o cadastro dessa universidade na "Plataforma Brasil", ${ }^{11}$ o protocolo de pesquisa deste estudo foi aprovado pelo Comitê de Ética da Secretaria Municipal de Saúde de São Paulo.

\footnotetext{
${ }^{9}$ CHIZZOTTI, Antonio. Pesquisa Qualitativa em Ciências Humanas e Sociais. 4 ed. Petrópolis/RJ: Editora Vozes, 2011. p. 28.

${ }^{10}$ SHECAIRA, Sérgio Salomão. Criminologia. São Paulo: Revista dos Tribunais, 2008.

${ }^{11}$ Plataforma on-line do Governo Federal responsável pela submissão de todos os protocolos de pesquisa com seres humanos aos respectivos Comitês de Ética. Disponível em:

<http://aplicacao.saude.gov.br/plataformabrasil/login.jsf>. Acesso em: 14 de janeiro de 2014.
} 
Não obstante a atividade de pesquisa seja uma prática teórica, vincula pensamento e ação. Nada pode ser intelectualmente um problema se não tiver sido, em primeiro lugar, um problema da vida prática. As questões de investigação estão, portanto, relacionadas a interesses e circunstâncias socialmente condicionadas. São frutos de determinada inserção na vida real, nela encontrando suas razões e seus objetivos. ${ }^{12}$

O problema da vida prática que motivou a realização deste trabalho foi a dúvida sobre a convivência harmoniosa entre a manutenção da lógica punitivo repressiva consubstanciada na criminalização do usuário de substâncias ilícitas e objetivo declarado da política pública respectiva, qual seja, a atenção e reinserção social do usuário.

Para responder essa questão, a pesquisa pretendeu uma análise da realidade que ultrapassasse os limites da teoria e, para tanto, utilizou-se do método qualitativo de pesquisa, que se ocupa com um nível de realidade "que não pode ou não deveria ser quantificado, vez que os seres humanos se caracterizam não só pela ação, mas pelos pensamentos acerca de seus atos, interpretando a realidade vivida"13.

Considerando que a manutenção da criminalização das condutas relacionadas ao uso de drogas viabiliza o exercício do poder repressivo do Estado contra os indivíduos usuários, ao menos num primeiro momento, a ideia de repreensão se afasta da ideia atenção integral para a reintegração do indivíduo e reencontro com as características socialmente aceitáveis para os padrões atuais (nos termos do discurso da política estatal). Nesta equação, temos que de um lado uma relação é hierárquica, impositiva, vertical, a outra, de outro lado, por essência, é baseada no consenso, autonomia, horizontal.

Para buscar essas conclusões era necessário compreender qual a relevância que criminalização e seus efeitos tem sobre os indivíduos a que ela se destina. Tratando-se de questão essencialmente subjetiva, era necessário que se discutisse a questão com os destinatários da referida política criminal/de saúde pública. O objeto do estudo, nesse caso "o criminoso" - compreendido como o usuário de uma substância considerada ilícita que

${ }^{12}$ MINAYO, Maria Cecília de Souza (Org.). Pesquisa Social: Teoria, método e criatividade. 30 ed. Petrópolis/RJ: Vozes, 2011, p.34.

${ }^{13}$ Ibidem, p. 21. 
tem a necessidade, em algum momento do uso, de portá-la para seu consumo- se insere no mundo real, não seria, pois, suficiente que a análise se circunscrevesse ao âmbito valorativo, como é tradicional às pesquisas acerca deste tema por profissionais com formação jurídica.

Assim, o método qualitativo de pesquisa foi escolhido por sua capacidade de fazer emergir aspectos novos, de ir ao fundo do significado e estar na perspectiva do sujeito, ajudando na construção do fenômeno, facilitando na descoberta de suas dimensões e, finalmente, permitindo a formulação e comprovação de novas hipóteses ${ }^{14}$.

\footnotetext{
[...] o debate qualitativo versus quantitativo revigora, de um lado, a contestação do modelo único de pesquisa, a crítica à hegemonia dos pressupostos experimentais, ao absolutismo da mensuração e à cristalização das pesquisas sociais em um modelo determinista, causal e hipotético dedutivo; adensam-se as críticas aos pressupostos ontológicos, epistemológicos e metodológicos do modelo convencional, reconhecendo-se a relevância do sujeito, dos valores dos significados e intenções da pesquisa, afirmando a interdependência entre a teoria e a prática, a importância da invenção criadora, do contexto dos dados e da inclusão da voz dos atores sociais.
}

Isso não significa dizer, no entanto, que a pesquisa deve, necessariamente, prescindir de dados de natureza quantitativa. Com efeito, os dois tipos de abordagem não necessariamente se excluem, podendo ser complementares de forma a elevar o grau de qualidade do estudo. O principal, com relação à metodologia, é que o pesquisador deixe claro qual o caminho seguido para que, enfim, fossem atingidas aquelas conclusões.

Ademais, muito embora o referencial teórico tenha sido brevemente exposto quando da submissão à banca de qualificação, a matéria que serviu de embasamento para compreensão dos dados colhidos empiricamente sofreu alterações significativas à medida que as respostas dos sujeitos entrevistados levaram a discussão para temas não imaginados no momento anterior à realização das entrevistas. A técnica é chamada de "atenção uniformemente suspensa" e, segundo Freud, permite que o pesquisador evite direcionar o estudo e, consequentemente, nunca descobrir nada além do que efetivamente já sabe.

\footnotetext{
14 OLIVEIRA, Lúcio Garcia. Avaliação da cultura do uso de crack após uma década de introdução da droga na cidade de São Paulo. - Crack cocaine culture evaluation a decade after its introduction in the city of São Paulo. São Paulo: s.n, 2007. 315fls. Tese (Doutorado em Ciências). Universidade Federal de São Paulo. Escola Paulista de Medicina, São Paulo, 2007.
} 
Em outras palavras, significa evitar que o pesquisador simplesmente direcione o resultado, posto que as questões que são apresentadas aos entrevistados já fazem com que o próprio entrevistado passe a refletir sobre uma questão que, talvez, não estivesse entre suas considerações, ou seja:

(...) assim que alguém, até certo ponto, concentra deliberadamente sua atenção, essa pessoa inicia uma seleção a partir do material à sua frente; um ponto estará fixado em sua mente com particular clareza, e outro será, igualmente, desconsiderado - ao fazer essa seleção, a pessoa estará seguindo suas expectativas ou propensões. Isso, no entanto, é precisamente o que não deve ser feito. Ao fazer essa seleção, se ela seguir suas expectativas, correrá o risco de nunca descobrir nada além do que já sabe ${ }^{15}$.

O estudo foi realizado junto ao PROAD - Programa de Orientação e Atendimento a Dependentes -, vinculado à Universidade Federal de São Paulo - UNIFESP. Para formação da amostra, foram consultados os prontuários de atendimento e selecionados os indivíduos que, no momento da triagem, relataram o uso de crack nos doze meses anteriores ao questionamento, resultando numa amostra de 36 (trinta e seis) pacientes. Destes, 4 (quatro) compareceram apenas para a triagem e 17 (dezessete) abandonaram o programa, ou após a triagem ou após algum tempo de tratamento, resultando em 17 (dezessete)pacientes que permaneciam frequentando o programa.

Desses, 2 (dois) estavam internados no período realização das entrevistas, 3 (três) negaram já ter consumido crack, embora constasse de seus prontuários e 1 (um) se negou a participar. A amostra, portanto, foi fechada em 11 (onze) pacientes em tratamento junto ao PROAD que relataram uso de crack no ano anterior à realização da triagem.

Em relação aos profissionais de saúde, foram entrevistados todos os profissionais integrantes da equipe fixa do PROAD, com exclusão apenas daqueles que tratavam de adolescentes ou de dependências não químicas, pois fugiam ao objeto de estudo. Também foi excluída uma profissional que se encontrava em licença maternidade. A amostra foi fechada em 16 (dezesseis) profissionais.

\footnotetext{
${ }^{15}$ FREUD, Sigmund apud FLICK, Uwe. Introdução à pesquisa Qualitativa. 3 ed. Porto Alegre: ArtMed,
} 2009. p.96. 
Antes da realização das entrevistas, esta pesquisadora compareceu por cerca de quatro meses ao grupo de acolhimento realizado todas as segundas-feiras na sede do PROAD como forma de conhecer o programa e viabilizar uma aproximação tanto dos pacientes quanto da equipe que facilitaria, num momento posterior, a realização das entrevistas. Dados dessa observação, apesar de não constituírem o método elegido como principal para a realização da pesquisa, serão comentados no decorrer do texto, haja vista ser impossível ignorar as experiências vivenciadas durante o período na formação da convicção sobre o tema e até na condução das entrevistas.

O convite para a participação na pesquisa foi feito diretamente por mim, na qualidade de pesquisadora e na forma verbal, pela leitura do Termo de Consentimento Livre e Esclarecido. Em alguns casos, os indivíduos eram convidados a participar da entrevista durante o grupo de acolhimento, após uma breve explanação sobre os objetivos da pesquisa, noutros casos, as entrevistas foram agendadas pela equipe do PROAD e o convite feito na forma verbal no horário designado. A única negativa de participação veio de um dos pacientes com horário agendado para entrevista. Todos os profissionais foram entrevistados com horário marcado em conversa comigo, na qualidade de pesquisadora.

Em todos os casos, foram explicados os objetivos do estudo, a necessidade de gravação da entrevista e a garantia de anonimato. Todas as entrevistas de pacientes foram realizadas nas dependências do PROAD. Em relação aos profissionais, alguns foram entrevistados nas dependências do PROAD e outros em seus consultórios particulares.

A coleta de dados foi realizada por meio de entrevistas semiestruturadas. As perguntas foram previamente estabelecidas, para tornar possível a comparação entre os dados colhidos, mas, no decorrer das entrevistas, conforme o entrevistado iniciasse a discussão de determinado assunto, questões eram inseridas ou suprimidas de modo que o sujeito tivesse liberdade para discorrer sobre os temas da forma que julgasse relevante, afastando, deste modo, aquele direcionamento que se pretendeu evitar.

Deste modo, na condução das entrevistas, cujo roteiro segue como apêndice, objetivou-se excluir ao máximo qualquer possibilidade de direcionamento dos resultados por uma tendência ideológica anterior à pesquisa. De fato, a presença próxima do investigador 
aos investigados tem aspectos extremamente positivos, pois permite uma melhor compreensão dos aspectos subjetivos pretendidos, mas pode, se não for bem cuidada, influenciar nos dados obtidos e resultados.

Conforme se afirmou, a pesquisa qualitativa não se encerra na simples análise de dados, senão numa participação direta com o objeto investigado a fim de entender todas as suas particularidades, natural, portanto, que tratando-se também de indivíduo que passa a interagir com o meio, o pesquisador deva se precaver contra eventuais direcionamentos. Isto porque:

\begin{abstract}
$\mathrm{Na}$ verdade não existe uma ciência neutra. Toda ciência - embora mais intensamente as ciências sociais - passa por interesses e visões de mundo historicamente criadas, embora suas contribuições e seus efeitos teóricos e técnicos ultrapassem as intenções de seus próprios autores. No entanto, as ciências físicas e biológicas participam de forma diferente da ideologia social [...] na investigação social, a relação entre o pesquisador e seu campo de estudos se estabelece definitivamente. A visão de mundo de ambos está implicada em todo processo de conhecimento, desde a concepção do objeto aos resultados do trabalho e à aplicação. Ou seja, a relação, nesse caso, entre conhecimento e interesse deve ser compreendida como critério da realidade e busca de objetivação ${ }^{16}$.
\end{abstract}

Não se ignora, no entanto, que todas as escolhas operadas desde a definição do tema da pesquisa, das bases teóricas e de como pesquisar são, mesmo em última instância, ideológicas. Não se trata de uma complacência com relação ao pesquisador que direciona seu estudo a uma ideia pré-concebida, mas a aceitação de que todo conhecimento científico é histórico e socialmente condicionado ${ }^{17}$.

Por lealdade científica, importa nesse momento salientar que o PROAD tem ideologia marcada, prezando a liberdade de escolha e a autonomia individual, bem como reconhecendo qualquer redução dos danos relacionados ao uso da droga como objetivos a serem perseguidos no tratamento. Dessa maneira, é natural que os pacientes ali submetidos a tratamento e, principalmente os profissionais que integram a equipe fixa do programa, tenham uma mentalidade que se distancia de uma visão autoritária.

\footnotetext{
${ }^{16}$ MINAYO, Maria Cecília de Souza (Org.). Pesquisa Social: Teoria, método e criatividade. 30 ed. Petrópolis/RJ: Vozes, 2011, p.34.

${ }^{17}$ Ibidem, p. 34.
} 
Realizadas as entrevistas, os depoimentos foram literalmente transcritos e utilizou-se a análise de conteúdo na modalidade temática, a qual se desdobrou em três etapas: préanálise, exploração do material, tratamento dos resultados obtidos e interpretação. $\mathrm{O}$ protocolo do projeto de pesquisa foi aprovado pelo Comitê de Ética em Pesquisa com Seres Humanos da Secretaria Municipal de Saúde de São Paulo, pelo Parecer n o 235.634. 


\section{O CRACK}

O crack é o pior do pior.

Entrevistado E3

O crack é um subproduto da cocaína, alcaloide natural extraído da planta Erythroxylon coca, estimulante do sistema nervoso central. Para obtenção do crack, o cloridrato de cocaína é dissolvido em água, adiciona-se bicarbonato de sódio, a mistura é aquecida e, ao secar, adquire a forma de pedras fumáveis. A cocaína em forma de crack, que tem seu surgimento atribuído aos Estados Unidos na década de 1980, recebeu esse nome muito provavelmente em virtude do barulho emitido pela combustão da pedra.

“E ela é um fenômeno... É a droga mesmo da marginalidade. É o resto da cocaína, que é a droga do capital. O cara cheira cocaína com todo um ritual. É cara e o cara cheira cocaína com a nota de um dólar e separa carreira com um cartão de crédito. E o crack é o subproduto disso e, por ser subproduto disso, é também utilizado pelos marginais”.

Entrevistado E11

Segundo o relatório da ONU sobre drogas de 2010, o Brasil é o maior mercado de cocaína na América do Sul com mais de 900 (novecentos) mil usuários ${ }^{18}$.O primeiro relato de uso de crack no Brasil ocorreu na cidade de São Paulo e faz referência ao ano de 1989. Apenas dois anos depois houve a primeira apreensão policial da droga ${ }^{19}$.

\footnotetext{
${ }^{18}$ UNODOC WORLD DRUG REPORT. Viena, 2010. Disponível em: <http://www.unodc.org/documents/wdr/WDR_2010/World_Drug_Report_2010_lo-res.pdf,>. Acesso em: 18 out. 2010. "A cocaína consumida no Brasil é uma das piores. Estima-se que em cada quilo de pasta base exportado, geralmente da Bolívia, os traficantes colocam 30 litros de derivados benzênicos; 20 litros de solventes orgânicos; um quilo de substâncias oxidantes e mais 4 quilos de produtos diversos, deixando a droga com apenas $30 \%$ de pureza. A pasta base que chega a São Paulo, é misturada com soda cáustica, solução de bateria de carro, água sanitária, cimento e manitol, um hormônio de engorda de gados. Além disso, são adicionados compostos inorgânicos, como o sulfato de magnésio, carbonato e bicarbonato de sódio, de cálcio e ácido bórico, carboidratos além de anestésicos, como a xilocaína, benzocaína e produtos antitérmicos e o analgésico fenacetina. Ao ser adicionado o enxofre e cloreto férrico, os traficantes passaram a produzir a cocaína amarela ou ocre e, para a obtenção das cores roxa e marrom o narcotráfico adiciona resina e pó-deserra”. (MUAKAD, Irene Batista. A cocaína e suas formas de consumo. São Paulo, 2009 Disponível em: <http://www.mackenzie.br/fileadmin/Graduacao/FDir/Artigos/artigos_2009/irene_04_09.pdf>. Acesso em: 20 out. 2010.

${ }^{19}$ OLIVEIRA, Lúcio Garcia; NAPPO, Solange Aparecida. Crack na cidade de São Paulo: acessibilidade, estratégias de mercado e formas de uso. Rev. psiquiatr. clín. - online, vol.35, n.6, pp. 212-218, 2008.
} 
Os primeiros estudos realizados em âmbito nacional sobre o uso de crack foram realizados alguns anos depois do primeiro episódio de uso relatado. O uso do crack ao longo da vida, estimado por dois levantamentos domiciliares realizados em âmbito nacional, aumentou de 0,4\%, em 2001, para 0,7\%, em 2005 (porcentagem calculada frente à população geral). Especificamente na Região Sudeste, o uso de crack na vida aumentou de 0,4 para $0,9 \%{ }^{2021}$.

Estudo mais recente no tema, promovido pela Fundação Oswaldo Cruz, apesar do alarde de seus resultados pela mídia, não encontrou situação muito diferente daquela constatada em 2005, muito embora tenha estudado amostra que inclui também indivíduos em situação de rua, população inacessível para os referidos estudos domiciliares. A estimativa encontrada nas capitais do país e Distrito Federal é na proporção de, aproximadamente, $0,81 \%^{22}$.

O surgimento e expansão do crack no Brasil são atribuídos à diversos fatores, dentre os quais, em estudos mais antigos: (a) a preocupação com a infecção pelo HIV, que fez com que os usuários passassem a temer o uso de drogas injetáveis e, consequentemente, o risco de infecção, (b) a aparente comercialização da droga por um custo menor, (c) à maior facilidade na fabricação, e (d) a promessa de efeitos mais intensos ${ }^{23}$. Em estudo mais recente, os fatores citados como ensejadores do consumo foram (a) vontade/curiosidade de sentir o efeito da droga - relatado por mais da metade dos entrevistados, (f) pressão dos amigos foi -

${ }^{20}$ CARLINI, E.A. et al. I Levantamento domiciliar nacional sobre uso de drogas psicotrópicas no Brasil (2001). São Paulo: Secretaria Nacional Antidrogas/Centro Brasileiro de Informações sobre Drogas Psicotrópicas, 2002.

${ }^{21}$ Idem. II Levantamento domiciliar sobre o uso de drogas psicotrópicas no Brasil: estudo envolvendo as 108 maiores cidades do país: 2005. São Paulo: CEBRID- Centro Brasileiro de Informação sobre Drogas Psicotrópicas: UNIFESP - Universidade Federal de São Paulo, 2006.

22 FUNDAÇÃO OSWALDO CRUZ. Estimativa do número de usuários de crack e/ou similares nas Capitais do País. Livreto epidemiológico. São Paulo, 2013. Disponível em: <http://portal.fiocruz.br/ptbr/content/maior-pesquisa-sobre-crack-j\%C3\%A1-feita-no-mundo-mostra-o-perfil-do-consumo-no-brasil>. Acesso em: 14 de janeiro de 2014.

${ }^{23}$ MUAKAD, Irene Batista. A cocaína e suas formas de consumo. São Paulo, 2009. Disponível em: <http://www.mackenzie.br/fileadmin/Graduacao/FDir/Artigos/artigos_2009/irene_04_09.pdf>. Acesso em: 20 out. 2010. 
relatada por $26,7 \%$ dos usuários, e (g) problemas familiares ou perdas afetivas - relatado por $29,2 \%$ dos usuários ${ }^{24}$.

Muito embora substituição do consumo de droga na forma intravenosa pelo risco de contágio pelo HIV seja relatado na realidade brasileira, recente pesquisa realizada pela fundação Oswaldo Cruz constatou que, diferentemente do encontrado em estudos internacionais, os usuários brasileiros de crack não são ex-usuários de drogas injetáveis, sugerindo a menor representatividade desse fator. Dentre os usuários de crack/similares no Brasil, apenas 9,2\% referiram ter feito uso anterior de droga injetável ${ }^{25}$.

Aliás, a fuga da possibilidade de contágio pelo HIV através da alteração na via de administração da droga seria fantasiosa. Isso porque o uso de crack vem associado, comumente, a comportamento sexual de risco. Nos dados coletados pela FIOCRUZ, mais de um terço dos usuários de crack/similares no Brasil (39,5\%), informaram não ter usado o preservativo em nenhuma das relações sexuais vaginais no mês anterior à entrevista relatando, inclusive, troca de sexo por droga ou dinheiro para conseguir a droga ${ }^{2627}$.

Além disso, na cidade de São Paulo, o uso de crack dá-se comumente mediante o emprego de cachimbos, e, embora esses cachimbos sejam confeccionados por uma infinidade de materiais, o certo é que a lata de alumínio é a principal "matéria-prima" dos aparatos para se fumar a pedra ${ }^{28}$. O alumínio aquecido a temperaturas altas acaba lesando o tecido dos lábios, rosto e dedos o que, além de ser um problema por si, viabiliza o contágio por doenças infectocontagiosas em virtude da troca de cachimbos - relatada por cerca de

${ }^{24}$ FUNDAÇÃO OSWALDO CRUZ. Estimativa do número de usuários de crack e/ou similares nas Capitais do País. Livreto epidemiológico. São Paulo, 2013, p. 22. Disponível em: <http://portal.fiocruz.br/pt$\mathrm{br} /$ content/maior-pesquisa-sobre-crack-j\%C3\%A1-feita-no-mundo-mostra-o-perfil-do-consumo-no-brasil>.

Acesso em: 14 de janeiro de 2014.

${ }^{25}$ Ibidem.

${ }^{26}$ OLIVEIRA, Lúcio Garcia; NAPPO, Solange Aparecida. Caracterização da cultura de crack na cidade de São Paulo: padrão de uso controlado. Revista de Saúde Pública, 2008.

27 "Importante notar a frequência elevada do relato de sexo em troca de dinheiro/drogas - 7,5\% (IC95\%: 5,6$9,9)$, quando comparada à população geral onde a proporção de profissionais do sexo é inferior a $1 \%$ (PCAP, 2008) (...) Em relação ao recebimento de dinheiro ou drogas em troca por sexo, dadas as assimetrias estruturais de gênero na sociedade brasileira, foram observadas diferenças importantes com relação ao engajamento de homens e mulheres. Dentre as mulheres, essa proporção foi de $29,9 \%$ e, entre os homens, 1,3\%". FUNDAÇÃO OSWALDO CRUZ. Op. Cit., p.. 22.

${ }^{28}$ Dentre os usuários de crack/similares, 28,3\% (IC95\%: 23,0-34,3) relataram usar a droga em copo plástico (com tampa de alumínio); 51,8\% (IC95\%: 47,8-55,7) em lata (cerveja/refrigerante) e 74,9\% (IC95\%: 70,379,1) em cachimbos. Ibidem, p. 18. 
$70 \%$ dos usuários ${ }^{29}$-, e aumenta a possibilidade de contágio por doenças sexualmente transmissíveis quando a prática é de sexo oral ${ }^{30}$ - a modalidade mais comumente identificável e praticada pelos homens e mulheres que trocam o sexo por droga ${ }^{31}$.

Com relação ao aparente menor custo da pedra em relação ao cloridrato de cocaína, estudos anteriores davam conta de que a cocaína comercializada na forma de crack parecia uma opção mais barata para o consumidor final e, por este motivo, teria atraído a atenção de uma parte mais vulnerável da população, ampliando o campo de abrangência da droga pra as camadas sociais desfavorecidas da população ${ }^{32}$. Os efeitos farmacológicos da substância aliados à população já vulnerável potencializaram a sua difusão de forma danosa e a associação com contextos de marginalidade, como se o crack fosse o responsável pela miséria social, e não o contrário.

Estudo mais recente, no entanto, demonstrou que o menor custo do crack em relação ao cloridrato de cocaína foi relatado como motivo central para o início do consumo da droga por menos de $2 \%$ dos usuários, sugerindo que o menor custo pode ensejar a manutenção do consumo, mas não foi considerado como determinante para a transição da via de administração da cocaína ${ }^{33}$.

Deve-se atentar, nesse ponto, que o referido "menor custo" do crack não passa de ilusão. Os subprodutos da cocaína consumidos na forma fumada geram efeitos mais intensos e menos duradouros no organismo, levando os usuários a um padrão de consumo compulsivo o que altera significativamente o "valor" da droga. Percebe-se que a vantagem econômica atribuída ao baixo custo não subsiste à medida que a necessidade da droga torna-se mais

${ }^{29}$ FUNDAÇÃO OSWALDO CRUZ. Estimativa do número de usuários de crack e/ou similares nas Capitais do País. Livreto epidemiológico. São Paulo, 2013. Disponível em: <http://portal.fiocruz.br/pt$\mathrm{br} /$ content/maior-pesquisa-sobre-crack-j\%C3\%A1-feita-no-mundo-mostra-o-perfil-do-consumo-no-brasil>. Acesso em: 14 de janeiro de 2014.

${ }^{30}$ OLIVEIRA, Lúcio Garcia de; NAPPO, Solange Aparecida. Crack na cidade de São Paulo: acessibilidade, estratégias de mercado e formas de uso. Rev. psiquiatr. clín. - online, v.35, n.6, pp. 212-218, 2008.

${ }^{31}$ Idem. Caracterização da cultura de crack na cidade de São Paulo: padrão de uso controlado. Revista de Saúde Pública, v., n., p., 2008.

${ }^{32}$ Em estudo qualitativo realizado pela professora Solange Nappo, o usuário perfil do usuário de crack foi definido como homem, jovem, solteiro, de baixa classe socioeconômica, baixo nível de escolaridade e sem vínculos empregatícios formais. Ibidem.

${ }^{33}$ FUNDAÇÃO OSWALDO CRUZ. Op. Cit., p. 15. 
intensa, o que faz com que o usuário tenha que despender maiores recursos para sustentar o uso.

Dependendo de como for consumida, a cocaína apresenta efeitos de duração e intensidade diferentes. Quando consumida por via intranasal, ou aspirada, boa parte do pó refinado prende-se à mucosa do nariz, onde é absorvido pela circulação local. O efeito da cocaína pode ser sentido minutos após a primeira administração e tem duração aproximada de 30 a 45 minutos. Quando fumada seus efeitos são sentidos em menos de 10 segundos e duram de 5 a 10 minutos $^{34}$, seguidos de uma fissura intensa por um novo episódio de consumo, caracterizando o uso compulsivo.

Aliás, a expectativa por efeitos mais rápidos e intensos do que os proporcionados pela cocaína aspirada é também descrita como motivo ensejador do início do consumo de $\operatorname{crack}^{35}$. Um estudo coordenado por Ronaldo Laranjeira ${ }^{36}$ a respeito da transição nas vias de administração da cocaína, concluiu que a primeira via de administração da cocaína é a aspirada $(88,5 \%)$ e a segunda via, o crack (82\%). Essa transição nas vias de administração não significa, necessariamente, o abandono da antecedente, sendo certo que há muitos indivíduos que consomem a cocaína em suas diferentes formas. O motivo alegado para a

${ }^{34}$ UNIDADE DE PESQUISAS EM ÁlCOOL E DROGAS (UNIAD), Departamento de Psiquiatria, Universidade Federal de São Paulo. Cocaína. Disponível em:

$\langle\mathrm{http}: / / \mathrm{www}$.uniad.org.br/index.php?option=com_content\&view=article\&id=84\&Itemid=96>. Acesso em 14 out. 2011.

${ }^{35}$ FUNDAÇÃO OSWALDO CRUZ. Estimativa do número de usuários de crack e/ou similares nas Capitais do País. Livreto epidemiológico. São Paulo, 2013, p. 15. Disponível em: <http://portal.fiocruz.br/pt$\mathrm{br} /$ content/maior-pesquisa-sobre-crack-j\%C3\% A1-feita-no-mundo-mostra-o-perfil-do-consumo-no-brasil>. Acesso em: 14 de janeiro de 2014..

${ }^{36}$ Graduação em Medicina pela Escola Paulista de Medicina (1982), Residência em Psiquiatria pela EPM (1984) e Phd em Psiquiatria pela Universidade de Londres(1994). Atualmente é Professor Titular do Departamento de Psiquiatria da Universidade Federal de São Paulo. Tem experiência na área de Psiquiatria, com ênfase em Alcoolismo e dependência de outras drogas. As principais áreas de pesquisa são: tratamento da dependência química, o impacto das políticas públicas do álcool e outras drogas, bases biológicas da dependência e avaliação epidemiológica do uso de substâncias. Na área de treinamento coordena vários cursos de pós graduação latu senso em dependência química (cursos de especialização presencial e virtual). Professor orientador do programa de pós-graduação do Departamento de Psiquiatria da UNIFESP. Coordenador da UNIAD (Unidade de Pesquisa em Álcool e Drogas) da UNIFESP. É o Investigador Principal do Instituto Nacional de Políticas do Álcool e Drogas, um dos recém criados INCTs (Instituto Nacional de Ciência e Tecnologia) do CNPq. Disponível em:

<http://buscatextual.cnpq.br/buscatextual/visualizacv.do?metodo=apresentar\&id=K4781161Z7〉. Acesso em: 25 dez. 2013. 
transição da primeira via (cocaína aspirada) para a segunda via (crack) foi a preferência pela intensidade dos efeitos em $51 \%$ dos $\operatorname{casos}^{37}$.

É essa combinação dos efeitos farmacológicos potencializados pelo padrão de uso é o que deixa os usuários mais suscetíveis à dependência. $\mathrm{O}$ uso pode se tornar rapidamente um uso compulsivo ${ }^{38}$.Um estudo conduzido nos Estados Unidos mostrou que $62 \%$ dos usuários de crack apresenta critérios positivos para dependência ao longo de sua carreira de consumo $^{39}$.

\begin{abstract}
A maioria da amostra, $62,8 \%$ experimentou dependência da cocaína em algum ponto de sua trajetória no uso da droga. Mesmo que o estudo sugira a possibilidade de se fumar crack por muitos anos sem se tornar dependente, ele mostra claramente que a dependência de cocaína é o resultado mais comum. Interessantemente, os grupos não diferiram em relação à idade de início de uso do crack ou da frequência de uso recente, sugerindo que a duração ou a quantidade de uso, embora sejam fatores inquestionavelmente importantes no desenvolvimento da cocaína, não são os únicos determinantes ${ }^{40}$.
\end{abstract}

Não obstante o estudo tenha concluído pelo desenvolvimento de dependência por mais da metade dos indivíduos que compunham a amostra, o fato é que a pesquisa afasta o senso comum de que toda pessoa que experimenta crack necessariamente tornar-se-á um viciado ou morrerá em poucos anos.

${ }^{37}$ LARANJEIRA, Ronaldo. Evolução do consumo de crack em coorte com histórico de tratamento. Revista de Saúde Pública. Disponível em:

$<$ http://www.uniad.org.br/index.php?option=com_content\&view=article\&id=10604:evolucao-do-consumode-crack-em-coorte-com-historico-de-tratamento\&catid=51:dependencia-quimica-artigos\&Itemid=93> . Acesso em: 14 out. 2011.

${ }^{38}$ INICIARDI apud RAUPP, Luciane; ADORNO, Rubens de Camargo Ferreira. Circuitos de uso de crack na região central da cidade de São Paulo (SP, Brasil). Ciênc. saúde coletiva - online, vol.16, n.5, pp. 26132622, 2011.

${ }^{39}$ FALCK RS, WANG J, CARLSON RG. Among long-term crack smokers, who avoids and who succumbs to cocaine addiction? Drug Alcohol Depend., v.98, p.24-29, 2008. Disponível em:

<http://www.ncbi.nlm.nih.gov/pmc/articles/PMC2564618/>. Acesso em: 14 de janeiro de 2014.

40 "The majority of the sample, $62.8 \%$, had experienced cocaine dependence at sometime during their drugusing careers. Although the results suggest it is possible to smoke crack for many years without becoming addicted to it, they clearly show that cocaine dependency is the most common outcome. Interestingly, the groups did not differ in the mean age of crack initiation or the frequency of recent crack use, suggesting that duration and amount of use, while unquestionably being critically important factors in the development of cocaine addiction, are not its sole determinants". FALCK RS, WANG J, CARLSON RG. Among long-term crack smokers, who avoids and who succumbs to cocaine addiction? Drug Alcohol Depend., v.98, p.2429, 2008. Disponível em: <http://www.ncbi.nlm.nih.gov/pmc/articles/PMC2564618/>. Acesso em: 14 de janeiro de 2014. 
A possibilidade de uso por longo período de tempo constatada no estudo referido acima vai ao encontro com os achados da recente pesquisa da Fundação Oswaldo Cruz, que constatou que, nas as capitais, o tempo médio de uso do crack e/ou similares foi de 91 meses (aproximadamente 8 anos), enquanto que nos demais municípios este tempo foi de, aproximadamente, 59 meses (5 anos). Nesse contexto, importa também dizer que já há relatos uso controlado de crack ocorridos na cidade de São Paulo ${ }^{41}$, o que possibilitaria a manutenção do uso por lapsos temporais maiores.

Há que se ter cuidado, portanto, com a ideia de que necessariamente os efeitos, ou alterações na atividade cerebral do indivíduo causadas pelo uso da droga, serão responsáveis por exacerbar comportamentos de natureza compulsiva, fazendo com que o usuário passe a direcionar as suas atividades diárias cada vez mais para a obtenção das substâncias, modificando significativamente seu desempenho no trabalho, nos estudos e no convívio com seus grupos sociais ${ }^{42}$. Como se viu, é o que acontece na maioria dos casos, mas não em todos eles.

De qualquer forma, quando comparado ao usuário de cocaína intranasal, o usuário de crack se expõe mais ao risco de dependência porque utiliza a droga com mais frequência, em maior quantidade e tem mais sensibilidade aos efeitos da substância ${ }^{43}$. Determinados tipos de drogas, cujo padrão de uso é classificado como compulsivo, também denominado a literatura como binge, dificultam o controle do indivíduo sobre a necessidade da substância, diminuindo sua capacidade de parar de usá-las, mesmo quando o efeito do uso já é menos gratificante, ou já interfere significativamente no funcionamento de outras áreas da sua vida.

O crack, quando consumido de modo compulsivo, leva o usuário a um esgotamento físico e psicológico após os episódios de uso. Como foi dito acima, muito embora seja um subproduto da cocaína, o crack, por sua constituição e modo de uso, traz para o indivíduo usuário diferenças consideráveis quanto à intensidade e duração dos efeitos provocados,

\footnotetext{
${ }^{41}$ OLIVEIRA, Lúcio Garcia; NAPPO, Solange Aparecida. Caracterização da cultura de crack na cidade de São Paulo. Padrão de uso controlado. Revista de Saúde Pública, 2008.

${ }^{42}$ RIBEIRO, Marcelo; LARANJEIRA, Ronaldo. O tratamento do usuário de crack. São Paulo: Artmed, 2012. p.23.

${ }^{43} \mathrm{CHEN}$ K, KANDEL D. Relationship between extent of cocaine use and dependence among adolescents and adults in the United States. Drug Alcohol Depend., v.68, p.65-85, 2002.
} 
levando à compulsão, à fissura ${ }^{44}$. Os usuários de crack, segundo pesquisa realizada por Feri, "tem mais episódios de fissura e perda do controle sobre o uso de droga do que os usuários de cocaína intranasal, levando-os a consumir grandes quantidades por diversas horas e dias consecutivos". 45

\begin{abstract}
Evidências científicas apontam para um maior potencial de uso nocivo e dependência quando a cocaína é fumada ou injetada em comparação com o uso intranasal. As principais características da via de administração relacionadas ao risco de uso nocivo ou dependência são a rapidez de início dos efeitos desejados e a intensidade e a duração desses efeitos, todos eles capazes de influenciar a frequência e a quantidade de cocaína consumida [...] Quanto mais instantâneos, intensos e efêmeros os efeitos, maior a probabilidade de a droga ser consumida novamente. A vida de administração, portanto, interfere diretamente no reforço positivo do uso compulsivo, aumentando a probabilidade do abuso e dependência ${ }^{46}$.
\end{abstract}

Um estudo qualitativo realizado em São Paulo com 40 (quarenta) usuários de crack constatou que além da fissura sentida na abstinência de crack e da fissura induzida de forma emocional, quando os usuários sentem o cheiro ou veem alguém usando a droga, existe outro tipo de fissura que faz parte do próprio efeito do crack. A última foi mencionada pelos usuários como importante fator de manutenção do uso compulsivo (binge), que foram os maiores responsáveis pelo rebaixamento de valores do usuário, sujeitando-o a práticas arriscadas para a obtenção da droga ${ }^{47}$.

Também em pesquisa recente foi possível constatar que cerca de 40\%dos usuários de crack no Brasil encontravam-se em situação de rua, o que não significa que necessariamente vivessem na rua, mas que lá permaneciam parte considerável de seu tempo. Ademais, é comum o relato de problemas familiares e a manutenção do uso através de

\footnotetext{
${ }^{44}$ Segundo o United Natios Office on Drugs and Crime (UNODOC) e a Organização Mundial de Saúde (OMS) a fissura pode ser caracterizada como um desejo intenso de usar novamente a substância para experimentar os efeitos provocados, sendo certo que esse desejo, por sua intensidade, vem acompanhado de oscilações de humor, do comportamento e da atividade cognitiva. A fissura seria "o reflexo de um estado subjetivo de motivação influenciado pelas expectativas positivas associadas ao consumo de uma dada substância". RIBEIRO, Marcelo; LARANJEIRA, Ronaldo. O tratamento do usuário de crack. São Paulo: Artmed, 2012. ${ }^{45} \mathrm{FERRI}$, Cleusa. Cocaína: Padrões de consumo e fatores associados à busca de tratamento. Tese: Universidade Federal de São Paulo: 1999.

${ }^{46}$ RIBEIRO, Marcelo; LARANJEIRA, Ronaldo. O tratamento do usuário de crack. São Paulo: Artmed, 2012. p.126 et. seq.

${ }^{47}$ CHAVES, Tharcila V. et al. Fissura por crack: comportamentos e estratégias de controle de usuários e ex-usuários. Rev. Saúde Pública - online, v.45, n.6, pp.1168-1175, 2011. Epub: 02 sep 2011.
} 
vínculos de emprego informais, o que sugere pouca inserção dessa população no tecido social $^{48}$.

Em outras palavras, muito embora o crack, numa observação puramente legalista, esteja classificado da mesma forma que todas as outras drogas - tendo, consequentemente, proibida qualquer forma de armazenamento, transporte, comercialização, uso - seu potencial lesivo e as características peculiares de seus dependentes acabam incitando a criação de políticas específicas, voltadas exclusivamente para essa droga ${ }^{49}$. "O usuário de crack geralmente tem efeitos negativos no status geral da saúde física, uma vez que seus pensamentos e comportamentos concentram-se em tornar possível o uso da droga, deixando de lado o autocuidado". 5051 Torna-se, portanto, improdutivo, custoso e visualmente incomodo, características quase impossíveis de coexistirem com a forma de organização da sociedade moderna.

Como relatado por quase todos os entrevistados, o crack é o "fundo do poço"!

\subsection{Perfil do Usuário de Crack}

Ser humano. Essa palavra "ser humano” me atrai, né? Eu preciso hoje, todos os dias, me ver como "um ser humano". Com sentimentos.

\section{Entrevistado P1}

O perfil recorrente do usuário de crack pouco mudou desde os primeiros estudos relacionados ao tema. Os usuários são, em sua maioria, indivíduos do sexo masculino, jovens

${ }^{48}$ FUNDAÇÃO OSWALDO CRUZ. Estimativa do número de usuários de crack e/ou similares nas Capitais do País. Livreto epidemiológico. São Paulo, 2013, p. 14. Disponível em: <http://portal.fiocruz.br/pt$\mathrm{br} /$ content/maior-pesquisa-sobre-crack-j\%C3\%A1-feita-no-mundo-mostra-o-perfil-do-consumo-no-brasil>. Acesso em: 14 de janeiro de 2014.

${ }^{49}$ Cf. Plano Nacional de Enfrentamento ao Crack. Disponível em:

<http://www.brasil.gov.br/enfrentandoocrack/plano-integrado/>. Acesso em: 14 de janeiro de 2014.

${ }^{50}$ RIBEIRO, L.A; SANCHEZ, Z.M; NAPPO, A.S. Surviving crack: a qualitative study of the strategies and tactics developed by Brazilian users to deal with the risks associated with the drug. BMC Public Health., v.10, n.671, 2010.

${ }^{51}$ Embora o consumo de crack ainda implique, frequentemente, padrões mais graves de dependência, alguns estudos de acompanhamento tem demonstrado que existem usuários que usam a droga de modo controlado, de forma menos frequente, até eventual. Há também relatos de pessoas que usam a droga há mais de dez anos e outros que foram diminuindo a intensidade do uso com o passar do tempo. RIBEIRO, Marcelo; LARANJEIRA, Ronaldo. O tratamento do usuário de crack. São Paulo: Artmed, 2012. p. 211. 
e adultos jovens, solteiros ${ }^{52}$, com baixa escolaridade, desempregados, provenientes de famílias desestruturadas e de baixa renda. ${ }^{53} 5455$

Estudo recente também constatou um predomínio significativo de usuários "nãobrancos" nas cenas de uso (aproximadamente apenas 20\% dos usuários de crack no Brasil eram de cor branca). Segundo o Censo 2010 realizado pelo Instituto Brasileiro de Geografia e Estatística (IBGE), os "não brancos" correspondiam a aproximadamente $52 \%$ da população brasileira, o que demonstra a sobrerrepresentação de pretos e pardos em contextos de vulnerabilidade social ${ }^{56}$.

No geral, os usuários de crack não relatam o uso único da substância, caracterizandose, na maior parte, em poliusuários. Recente pesquisa observou forte superposição do uso de crack e similares com o consumo de drogas lícitas $(80 \%)^{57}$.

Muito embora haja relatos de uso de crack por crianças, estudo recente da Fundação Oswaldo Cruz não observou uma quantidade expressiva de crianças e adolescentes nos locais visitados para a realização da pesquisa $^{58}$.

Em relação ao usuário de cocaína intranasal, os usuários de crack apresentam um padrão mais grave de consumo, maior envolvimento em atividades ilegais e prostituição, maior risco dos efeitos adversos da substância e maior chance de morar ou ter morado na

\footnotetext{
52 "A maioria dos usuários de crack declarou ser solteira - 60,6\% (IC95\%: 57,8-63,4). Segundo o Censo 2010, na população geral brasileira, a proporção de solteiros é de 55,3\%. Portanto, há uma sobrerrepresentação de solteiros nas cenas de crack, como costuma ser observado em diferentes situações de afrouxamento dos laços familiares". FUNDAÇÃO OSWALDO CRUZ. Estimativa do número de usuários de crack e/ou similares nas Capitais do País. Livreto epidemiológico. São Paulo, 2013, p. 10. Disponível em: $<$ http://portal.fiocruz.br/pt-br/content/maior-pesquisa-sobre-crack-j\%C3\%A1-feita-no-mundo-mostra-operfil-do-consumo-no-brasil>. Acesso em: 14 de janeiro de 2014.

${ }^{33}$ OLIVEIRA, Lúcio Garcia. Avaliação da cultura do uso de crack após uma década de introdução da droga na cidade de São Paulo. - Crack cocaine culture evaluation a decade after its introduction in the city of São Paulo. São Paulo: s.n, 2007. 315fls. Tese (Doutorado em Ciências). Universidade Federal de São Paulo. Escola Paulista de Medicina, 2007.

${ }^{54}$ Idem. Crack na cidade de São Paulo: acessibilidade, estratégias de mercado e formas de uso. Rev. psiquiatr. clín. - online, v.35, n.6, pp.212-218, 2008.

${ }^{55}$ FUNDAÇÃO OSWALDO CRUZ. Op. Cit.. Disponível em: <http://portal.fiocruz.br/pt-br/content/maiorpesquisa-sobre-crack-j\%C3\%A1-feita-no-mundo-mostra-o-perfil-do-consumo-no-brasil>. Acesso em: 14 de janeiro de 2014, p. 10.

${ }^{56}$ Ibidem, p. 9.

${ }^{57}$ Ibidem, p. 14.

${ }^{58}$ Ibidem, p. 14.
} 
rua $^{59}$. Esses fatores psicossociais como o isolamento social e a vulnerabilidade à violência urbana contribuem para a manutenção do consumo, enfatizando como os processos sociais e fatores contextuais tem participação determinante nos padrões de uso da droga ${ }^{60}$.

A marginalização, como já se viu, pode ser atribuída ao próprio uso da droga, mas, sendo possível constatar que, em sua maioria, os usuários provém de famílias desestruturadas ${ }^{61}$ e de baixa renda, é possível questionar se a exclusão não precede o início do uso do crack, uma vez que a maioria dos usuários já fazia parte de grupos excluídos da sociedade ${ }^{62}$.

Nesse ponto, estudo recente realizado na área central de São Paulo conhecida como "Cracolândia", verificou que muitas das pessoas entraram em contato com o crack quando já estavam em situação de rua, casos em que a droga não pode ser indicada como a causa da ida à rua, embora essa relação seja verdadeira para a maior parte dos casos observados ${ }^{63}$. Muito embora isso não signifique "morar na rua" aproximadamente $40 \%$ dos usuários no Brasil se encontravam em situação de rua, passando nelas parte expressiva do seu tempo ${ }^{64}$.

Ademais, não obstante haja relatos de uso de crack por cidadãos de situação econômica estável, que o desenvolvem em contextos protegidos, cerca de $80 \%$ dos usuários

\footnotetext{
${ }^{59}$ HATSUKAMI, DK, FISHMANN, MW apud RIBEIRO, Marcelo; LARANJEIRA, Ronaldo. O tratamento do usuário de crack. São Paulo: Artmed, 2012. p. 39.

${ }^{60}$ VALDEZ A, CEPEDA A, NEJI NJ, KAPLAN C apud RIBEIRO, Marcelo; LARANJEIRA, Ronaldo. O tratamento do usuário de crack. São Paulo: Artmed, 2012. p. 40.

${ }^{61}$ Estudo da Fundação Oswaldo Cruz constatou que 29,2\% dos entrevistados disseram que um dos motivos para início do uso da droga foram os problemas familiares ou perdas afetivas. FUNDAÇÃO OSWALDO CRUZ. Estimativa do número de usuários de crack e/ou similares nas Capitais do País. Livreto epidemiológico. São Paulo, 2013. Disponível em: <http://portal.fiocruz.br/pt-br/content/maior-pesquisasobre-crack-j\%C3\%A1-feita-no-mundo-mostra-o-perfil-do-consumo-no-brasil>. Acesso em: 14 de janeiro de 2014.

${ }^{62}$ Eugenio Raul Zaffaroni, discorrendo sobre a política criminal na globalização, declara que a principal consequência social deste fenômeno foi a substituição da lógica explorador-explorado, própria da sociedade industrial, para a lógica incluído-excluído, sendo certo que "o excluído não é o explorado: o último é necessário ao sistema; o primeiro está demais, sua existência mesma é desnecessária e molesta, é um descartável social". ZAFFARONI, Eugenio Raul; OLIVEIRA, Edmundo. Criminologia e Política Criminal. Rio de Janeiro: GZ Editora, 2010.

${ }^{63}$ RAUPP, Luciane; ADORNO, Rubens de Camargo Ferreira. Circuitos de uso de crack na região central da cidade de São Paulo (SP, Brasil). Ciênc. saúde coletiva - online, v.16, n.5, pp.2613-2622, 2011.

${ }^{64}$ FUNDAÇÃO OSWALDO CRUZ. Op. Cit., p. 12.
} 
de crack utiliza a droga espaços públicos ${ }^{65}$, ficando mais vulneráveis às situações de violência urbana que envolvem os circuitos de uso do crack.

Pesquisas também sugerem a existência de uma estreita relação entre a situação e o contexto social dos usuários e seu padrão de uso de crack. A grande maioria daqueles em situação de rua apresentavam um padrão de uso compulsivo no qual o autocuidado ou quaisquer outras atividades eram secundarizadas frente ao consumo frenético da droga ${ }^{66}$, ressaltando a importância de serviços de assistência social direcionados a essa parcela específica da sociedade.

Outro ponto que gera preocupação é a forma como os usuários custeiam o vício. Quando traçado o perfil do usuário, dificilmente se encontram relatos de vínculos empregatícios formais, sendo certo que a forma mais comum de obtenção de dinheiro compreende os trabalhos informais - esporádicos ou autônomos (65\%). Também é comum o relato de sexo em troca de dinheiro/drogas, relatada por cerca de 7,5\% dos usuários $(29,9 \%$ entre as mulheres e, entre os homens, $1,3 \%)^{67}$.

A prostituição aliada ao comportamento sexual de risco aumentam as chances de contaminação por doenças infecto contagiosas. Comparados com a população brasileira, os usuários de crack/similares apresentaram prevalência de HIV cerca de 8 (oito) vezes maior do que a da população geral $(5,0 \% \text { vs. } 0,6 \%)^{68}$.

Os usuários de crack, dentre os usuário de drogas ilícitas, são os que menos procuram tratamento, restringindo a busca à situações agudas e insustentáveis ${ }^{69}$. Ademais a falta de auto cuidado geral faz com que grande número dos usuários tenha a primeira aproximação com o sistema de saúde incitada por complicações clínicas relacionadas com o uso da droga,

${ }^{65}$ FUNDAÇÃO OSWALDO CRUZ. Estimativa do número de usuários de crack e/ou similares nas Capitais do País. Livreto epidemiológico. São Paulo, 2013, p. 12. Disponível em: <http://portal.fiocruz.br/ptbr/content/maior-pesquisa-sobre-crack-j\%C3\%A1-feita-no-mundo-mostra-o-perfil-do-consumo-no-brasil>. Acesso em: 14 de janeiro de 2014.

${ }^{66}$ RAUPP, Luciane; ADORNO, Rubens de Camargo Ferreira. Op. Cit. p. 5.

${ }^{67}$ FUNDAÇÃO OSWALDO CRUZ. Op. Cit, p. 22.

${ }^{68}$ Ibidem, p. 25.

${ }^{69}$ RIBEIRO, Marcelo; LARANJEIRA, Ronaldo. O tratamento do usuário de crack. São Paulo: Artmed, 2012. p. 90. 
mas não diretamente por essa situação ${ }^{70}$. Por fim, os usuários de cocaína como um todo são os pacientes que apresentam maior índice de abandono do tratamento, sendo certo que, dentre eles, os usuários de crack apresentam índices muito maiores do que o dos demais ${ }^{71}$.

Entre os motivos ensejadores da busca pelo tratamento, os pacientes, quando perguntados sobre as razões que os levaram ao tratamento, relataram infecção por HIV, perigo de overdose, síndrome do pânico, estado de depressão, entre outras condições indesejáveis decorrentes do uso da droga:

“(...)antes de eu descobrir que estava com HIV, eu levava uma vida... Me formei, estudei, trabalhava, então não me atrapalhava, entendeu? Aí a partir do momento que o alcoolismo, mais o alcoolismo, e a droga a começou a me atrapalhar, e tive o problema do HIV também, né? Que você tem que tá com o organismo bom, aí sim eu procurei tratamento.

(...) eu fiz exame no começo do ano. Eu tô com 700 de triglicerídeos. Isso para você desencalhar uma pancreatite ou uma... Porque quando passa da 500 você tem que entrar com medicação. porque o normal é 160. Então eu com 700; isso aí pode dar uma pancreatite, como posso vir a ficar diabético, que nem meu pai ficou; que foi alcoólatra. Tenho outro conhecido também que foi alcoólatra. Meи pai foi porque morreu, morreu bebendo. Esse conhecido ele parou, mas ficou diabético, então... E fora o figado, porque se você danificar muito ele e tiver que tomar a medicação... Olha, um exemplo muito clássico, quando eu tive essa infecção intestinal, que eu perdi 15 quilos, que eu fiquei doente, eu tive que fazer um exame de pâncreas, amilase e lipase, e os parâmetros de fígado, fora os hemogramas para ver a infecção, que eram TGP, TGO e Gama GT. O que acontece? Para ver se eu tinha condições de suportar o antibiótico que eu ia tomar; porque eu tomei um antibiótico muito forte, o Ciclofloxacina. Então se o meu fígado não estivesse em condição, então é por isso que eu preciso, tenho que estar atrás, né? de reduzir."

\footnotetext{
${ }^{70}$ RIBEIRO, Marcelo; LARANJEIRA, Ronaldo. O tratamento do usuário de crack. São Paulo: Artmed, 2012, p.193.

${ }^{71}$ Ibidem, p.197.
} 


\section{Entrevistado P3}

"Eu trabalhava em uma construtora, então peguei um dinheiro alto assim e aí tive quase dois começos de overdose. Só na cocaína. Aí me decidi internar porque tava [sic] sem controle. (...) Aí saí, aí voltei ao uso depois de dois meses. Isso tudo cocaína. Aí depois vim experimentar o crack. Sempre saía, mas às vezes dava umas afundadas de dois dias no crack. Me colocava [sic] em situação de risco porque eu ficava realmente com medo. Começou a me dar muita depressão após o uso do crack, que é uma coisa horrível. Depois eu decidimeu pai trabalha no Emílio Ribas - pedi uma ajuda para ele; consegui uma internação de 30 dias lá no Hospital das Clínicas, porque a melhor internação que eu tive foi aonde [sic] foi diagnosticada a bipolaridade."

\section{Entrevistado P4}

"Então... Antes disso eu tive um acidente de moto muito sério. Tive uma parada cardíaca e respiratória durante a cirurgia, devido à cocaína. E isso aí foi me despertando esse outro lado para buscar ajuda.,

\section{Entrevistado P8}

"E aí eu tive um AVC em 2005, janeiro de 2005, por motivo da cocaína. Não usava crack, nunca usei, nunca tinha usado. Aí, em 2004 eu saí da firma. Em 2005 eu tive o AVC e conheci aqui diretamente o Proad. Fiquei 4 anos me tratando aqui. Tive duas internações. Aí 4 anos atrás eu parei de vir aqui (...)Como eu trato desse AVC, dois meses atrás me alterou bastante. Aí eu caí na minha mãe por causa que eu tava [sic] drogado e começou a vir todos os problemas de novo. Aí eu fui pro médico. Tô [sic] aqui já há dois meses."

\section{Entrevistado P9}

"Foi quando eu tinha um problema no fígado, que eu fiz uns exames em São Paulo, fiz um checkup. No posto eu fiz. Com uma doutora. Ela me passou exame, pra mim fazer [sic] todos os exame [sic], né? Completo. Fazer um checkup e aí acusou Hepatite C. Aí eles me encaminharam parao Hospital São Paulo. Aí eu estava me tratando e eu fiz biópsia, tirei um pedaço do fígado. Eu tomei 
Ribaverina. Tomei Tejo. Depois de 6 meses me deram alta. E mais ou menos eu tô [sic] no Hospital São Paulo tem uns 12 a 13 ano [sic]. “

Entrevistado P10

Como já se afirmou, o comprometimento da saúde geral, o desinteresse por atividades não relacionadas à droga e a dificuldade na manutenção do tratamento podem ser associados à forma de uso do crack: "o padrão de consumo intenso, contínuo e repetitivo de crack, chamado de binge, é provocado pela fissura e pode durar dias até que o suprimento de droga termine, ou que haja a exaustão do usuário"72.

Essa realidade pode estar atrelada ainda ao fato de que o uso crônico da cocaína produz alterações cognitivas que tem sua reversibilidade controvertida. De modo geral, os estudos indicam que, iniciado o tratamento e mantida a abstinência, sempre há melhora. No entanto, outras pesquisas realizadas com pacientes abstinentes há mais de seis meses puderam constatar que os déficits permaneceram, sugerindo que o uso crônico pesado de cocaína e crack pode resultar em perdas cerebrais irreparáveis ${ }^{73}$.

O usuário é, sem sombra de dúvida, a parte mais frágil de toda a complexa cadeia que envolve o uso de drogas. Muito embora a Lei $\mathrm{n}^{\circ} 11.343 / 2006$ tenha operado um avanço legislativo no que se refere à abordagem do porte de drogas para uso pessoal, prevendo como objetivos a serem alcançados seu tratamento e reinserção social, o fato é que a cultura jurídica ainda reflete os valores característicos do sistema exclusivamente repressivo.

A cultura de guerra e de repressão, muito embora tenha sido superada pelo diploma legal é a postura política que ainda orienta os operadores do direito, o que prejudica imensamente a aplicação concreta da política de atenção que se pretendia dispensar aos usuários, mantendo-os desamparados.

\footnotetext{
72 CHAVES, Tharcila V. et al. Fissura por crack: comportamentos e estratégias de controle de usuários e ex-usuários. Rev. Saúde Pública - online, v.45, n.6, pp.1168-1175, 2011. Epub: 02 sep. 2011.

${ }^{73}$ RIBEIRO, Marcelo; LARANJEIRA, Ronaldo. O tratamento do usuário de crack. São Paulo: Artmed, 2012. p.259.
} 


\subsection{CRACK: O INIMIGO PÚBLICO NÚMERO UM}

Como se o crack fosse o grande câncer do mundo agora. Tipo, é o grande problema, a grande doença que a gente tem hoje é o crack. E é irreal, não é?

Entrevistado E10

Segundo Maurides de Melo Ribeiro, em sua dissertação de mestrado apresentada também nessa Universidade, as modernas políticas de drogas surgiram para:

Equacionar a nova realidade oriunda do consumo de substâncias psicoativas dentro do contexto sócio-cultural das nações ocidentais, uma vez que a utilização das substâncias de forma desenfreada e sem qualquer mecanismo informal de controle social, revelou-se problemática. ${ }^{74}$

É que, a partir do século XIX o consumo de drogas foi popularizado sem que se disseminassem, também, os lastros culturais que ensejam a prática, mas funcionavam também como limitadores do abuso das substâncias. Sem os mecanismos informais de controle, o uso de drogas passou a ser acompanhado de casos de intoxicação aguda, afrouxamento de vínculos sociais e complicações na saúde que geravam custos indesejáveis para o sistema de saúde. As políticas são, então, traçadas como tentativa de solucionar os problemas trazidos pelo uso desenfreado de algumas substâncias.

É quase - e em tese - uma relação matemática. Analisa-se o impacto atual e futuro gerado pelo uso da substância e então traçam-se políticas a fim de solucionar ou minimizar o referido custo social.

Deixando, por ora, de lado todas as críticas que se podem fazer a um política proibicionista que, durante sua vigência, demonstrou causar mais prejuízos do que vantagens, o fato é que, sob os fundamentos do controle da difusão do seu uso e dos complicadores a ele associados, a questão das drogas tem sido objeto de preocupação já há algum tempo.

\footnotetext{
${ }^{74}$ RIBEIRO, Maurides de Melo. Políticas públicas e a questão das drogas: o impacto da política de redução de danos na legislação brasileira de drogas. 2007. Dissertação (Mestrado em Direito). Universidade de São Paulo, 2007.
} 
Em relação ao crack, parece-me que, de uns tempos pra cá, os discursos políticos têm alçado a droga a um patamar diferenciado. Teríamos então, três situações problemáticas: o consumo de drogas lícitas, o consumo de drogas ilícitas e o consumo de crack.

Desde a constatação do primeiro episódio de uso de crack em São Paulo o número de usuários que procuram o sistema de saúde em virtude do crack aumentou ${ }^{75}$, fazendo com que o assunto tenha sido tratado por representantes do governo como epidemia ${ }^{76}$. Nesse sentido foi o discurso do então Ministro da Saúde, Exmo. Sr. Alexandre Padilha, proferido no final do ano de 2011, no lançamento da campanha "Crack, é possível vencer" do Governo Federal:

\footnotetext{
Em primeiro lugar reconhecermos, tecnicamente, que nós estamos diante sim de uma epidemia do crack no nosso país (...) Nós temos que dar para esse problema do crack um tratamento de surto epidêmico. Todo agravo a saúde que apresenta uma variação no número de casos que supera a série histórica, que muda o seu perfil regional, de localização dessa ocorrência e que ultrapassa os grupos tradicionais e começa a acometer outros grupos. E esse é o conceito que o Ministério da Saúde, o conjunto do governo e a sociedade assumem. ${ }^{77}$
}

Muito embora não se ignore o fato de que o número de usuários de crack aumentou desde que a droga surgiu no Brasil, o fato é que, segundo pesquisas realizadas, a situação está longe de configurar uma epidemia. Nos Levantamentos Domiciliares realizados pelo CEBRID, o número de usuários de crack em comparação com a população geral passou de $0,4 \%$ em $2001^{78}$ para $0,7 \%$ em $2005^{79}$. Na pesquisa mais recente realizada pela fundação Oswaldo Cruz que, ao contrário dos mencionados Levantamentos, analisou também população em situação de rua, não mais restringindo à análise a pessoas domiciliadas, constatou que estimativa encontrada para a população que consome crack e/ou similares de

\footnotetext{
${ }^{75}$ SILVA, Gilberto Lucio da (Org.). Drogas: Políticas e práticas. São Paulo: Roca, 2011. p. 77.

${ }^{76}$ OLIVEIRA, Lúcio Garcia. Avaliação da cultura do uso de crack após uma década de introdução da droga na cidade de São Paulo. - Crack cocaine culture evaluation a decade after its introduction in the city of São Paulo.São Paulo: s.n, 2007. 315fls. Tese (Doutorado em Ciências). Universidade Federal de São Paulo. Escola Paulista de Medicina, 2007.

${ }^{77}$ Disponível em: <http://www.youtube.com/watch?v=EZF8zE4leg4>. Acesso em: 07 nov. 2013.

78 SECRETARIA NACIONAL ANTIDROGAS (SENAD). GABINETE DE SEGURANÇA INSTITUCIONAL. I Levantamento Domiciliar Sobre o Uso de Drogas Psicotrópicas no Brasil. São Paulo, 2001.

${ }^{79}$ Ibidem.
} 
forma regular é na proporção de, aproximadamente, $0,81 \%^{80}$, resultado que não se distancia da realidade encontrada em 2005.

Os dados apontam que o uso do cloridrato de cocaína ainda é muito superior ao uso do crack, mas o governo tem se referido à essa modalidade de uso como se ela fosse prevalente sobre todas as outras drogas. Tarcísio Andrade ${ }^{81}$, professor da Universidade Federal da Bahia, em artigo publicado na Revista Poli, da fundação Oswaldo Cruz alerta para o fato de que, graças à criação desses programas específicos de combate a droga, o crack tem sido utilizado politicamente para garantir o acesso aos recursos disponibilizados pelo governo federal:

\begin{abstract}
Quando o governo anunciou $\mathrm{R} \$ 4$ bilhões para o crack, logo em seguida saiu uma pesquisa dizendo que a grande maioria dos municípios tinha problema com seu uso. Da maneira como a nossa política funciona, se a pessoa sabe que tem recurso disponível e você chega à cidade e pergunta se tem problema com o crack, é claro que ela vai dizer que tem. ${ }^{82}$
\end{abstract}

Além disso, a utilização do termo epidemia para referir o uso de crack no Brasil reforça ainda mais o estigma que pesa sobre o usuário, aumentando o distanciamento existente entre a população geral este extrato já marginalizado.

${ }^{80}$ FUNDAÇÃO OSWALDO CRUZ. Estimativa do número de usuários de crack e/ou similares nas Capitais do País. Livreto domiciliar. São Paulo, 2013. Disponível em: <http://portal.fiocruz.br/ptbr/content/maior-pesquisa-sobre-crack-j\%C3\%A1-feita-no-mundo-mostra-o-perfil-do-consumo-no-brasil >.

Acesso em: 14 de janeiro de 2014.

${ }^{80}$ Possui graduação em Medicina Universidade Federal da Bahia (1980), mestrado em Medicina Universidade Federal da Bahia (1988) e doutorado em Medicina pela Universidade Federal da Bahia (1996), título de Psicanalista pelo Círculo Psicanalítico da Bahia e Círculo Brasileiro de Psicanalise (1985), estágios de aperfeiçoamento em Pesquisa pela Universidade Califórnia, Berkely (1993, 1998 e 2003). Atualmente é professor associado IV do Departamento de Saúde da Família da Faculdade de Medicina da Bahia/UFBA, lecionando no Curso de Graduação em Medicina e no Programa de Pós-graduação em Medicina e Saúde; neste último é o professor responsável pela disciplina Psicologia Médica, e pela orientação de pós-graduandos a nível de mestrado e doutorado; é o Coordenador do Serviço de Extensão Permanente Aliança de Redução de Danos Fátima Cavalcanti da Faculdade de Medicina da Bahia da Universidade Federal da Bahia, voltado para prevenção, tratamento, ensino, pesquisa e formulação de Políticas Públicas relacionadas ao uso de drogas, na ótica da Redução de Danos; É coordenador do Centro de Atenção Psicossocial para pessoas que usam álcool e outras drogas - CAPSad Gregório de Matos, serviço docente e assitencial da Faculdade de Medicina da Bahia - FMB/UFBA. É membro do Conselho Acadêmico de Pesquisa e Extensão - CAPEX/UFBA; da Congregação da Faculdade de Medicina da Bahia - FMB/UFBA e membro do Conselho Editorial da revista Toxidependências Editada pelo Ministério da Saúde - Instituto da Droga e da Toxicodependência da Portugal. Disponível em:

<http://buscatextual.cnpq.br/buscatextual/visualizacv.do?metodo=apresentar\&id=K4785508T8>. Acesso em: 25 dez. 2013.

${ }^{82}$ FUNDAÇÃO OSWALDO CRUZ. Revista Poli: Saúde, Educação e Trabalho. Ano V, n.27, mar/abr-2013. p.19. 
A palavra epidemia é péssima, perigosa, inclusive, porque dá a ideia de uma coisa contagiosa. Vamos imaginar que eu seja usuário de crack e esteja junto de você? Você vai se contagiar e começar a fumar crack? Óbvio que não, mas epidemia é assim. Acredito que falar em epidemia de crack serve até para colocar uma questão que é social como uma doença. E aí os usuários de crack passam a ser vistos como perigosos, pessoas que podem contaminar a sociedade. ${ }^{83}$

Durante a realização das pesquisas, quando questionados se se sentiam diferentes das outras pessoas por serem usuários de drogas, a resposta dos entrevistados foi sempre positiva. Os trechos das entrevistas, bem como considerações mais profundas sobre o efeito prejudicial da estigmatização dessas indivíduos no abandono do uso serão tratados em capítulo próprio.

No mesmo sentido, os profissionais participantes das entrevistas afirmaram que o preconceito existe entre os próprios usuários de drogas, afirmando que aqueles que usam drogas lícitas, no geral, pensam que sofrem de um problema diferente dos usuários de drogas ilícitas e, dentre os usuários de drogas ilícitas, o usuário de crack é considerado ainda pior.

Mais razoável seria, portanto, pensar que o tratamento diferenciado decorre dos efeitos farmacológicos da substância, que influenciam no padrão de uso compulsivo e no afrouxamento dos laços sociais, retirando esses indivíduos da parcela produtiva da população. Para o senso comum, o crack marginaliza seus usuários.

Com o crack é diferente. Embora já haja pesquisas que demonstrem o uso controlado da droga ${ }^{84}$ o uso compulsivo ainda é o mais comum. A relação criada com a droga afrouxa os vínculos que até então subsistiam e o indivíduo passa a viver, basicamente, em função da droga. Não produzem, não consomem. São descartáveis. Na lógica do capitalismo globalizado, esse tipo de gente não interessa. São custo desnecessário. Daí a ideia de um muitíssimo maior custo social associado ao crack.

Eugenio Raul Zaffaroni, em brilhante artigo sobre a sociedade globalizada, explica que:

${ }^{83}$ FUNDAÇÃO OSWALDO CRUZ. Revista Poli: Saúde, Educação e Trabalho. Ano V, n.27, mar/abr2013,p. 18.

${ }^{84}$ OLIVEIRA, Lúcio Garcia; NAPPO, Solange Aparecida. Caracterização da cultura de crack na cidade de São Paulo: padrão de uso controlado. Revista de Saúde Pública, 2008. 
A principal consequência social deste fenômeno de poder é a geração de um amplo e crescente setor excluído da economia. A relação explorador - explorado foi substituída por uma não relação incluído - excluído (...) O excluído não é o explorado: o último é necessário ao sistema; o primeiro está demais, sua existência mesma é desnecessária e molesta, é um descartável social. ${ }^{85}$

Embora o autor não estivesse discorrendo especificamente sobre os usuários de droga é possível aplicar-lhes o raciocínio à medida que, ainda quando não proveem das classes já materialmente excluídas, acabam inviabilizando sua participação na sociedade de consumo à medida que direcionam suas atividades apenas para a obtenção da droga.

Deve-se atentar, no entanto, para o fato de que a miséria pode ser antecedente ao uso, e não consequência da relação indivíduo-droga:

Quando se diz que a pessoa que usa crack vai ficar na rua, na sarjeta, esquece-se que já existia rua e sarjeta antes do crack. E provavelmente, pra essas pessoas vivendo nas ruas em condições extremamente desfavoráveis, o crack dá um suporte, ao melhorar o estado de ânimo diante de uma realidade terrível. Ele é um estimulante, um antidepressivo, tira a fome do indivíduo mal alimentado. Há um ciclo vicioso, mas que não começou com a droga, ela chega em um segundo momento. $^{86}$

O próprio Ministro da Saúde, no discurso de apresentação daquele programa "Crack, é possível vencer", conforme supramencionado, reconhece essa realidade:

Pessoas usam o crack as vezes para enfrentar a exclusão no ambiente urbano, na situação de moradia na rua, e pessoas usam o crack como uma forma de inclusão, que são pessoas que usam o crack pra trabalhar mais, pra produzir mais, como no ambiente rural. ${ }^{87}$

Quase todos os usuários entrevistados relatam uma condição de vida e relacionamentos interpessoais absolutamente precários mesmo antes do início de consumo de drogas.

Não era muito chegado [no meu pai]. Porque ele batia na minha mãe quando eu era pequeno. Por nada. De graça. Sabe de graça? Ele tem problema mental também. Eu até entendo isso, entendeu? [...]Tenho poucas palavras disso aí

${ }^{85}$ ZAFFARONI, Eugenio Raul; OLIVEIRA, Edmundo. Criminologia e Política Criminal. Rio de Janeiro: GZ Editora, 2010. p.165.

${ }^{86}$ FUNDAÇÃO OSWALDO CRUZ. Revista Poli: Saúde, Educação e Trabalho. Ano V, n.27, mar/abr-2013. p. 20.

${ }^{87}$ Disponível em: <http://www.youtube.com/watch?v=EZF8zE4leg4>. Acesso em: 07 nov. 2013. 
agora e também não tô a fim de lembrar muito esse momento agora não. Mas ele batia na minha mãe de graça muitas das vezes. Não estava nem caindo, nem nada. De graça! De graça! Até que eu comecei... Eu fumei cigarro... Eu aprendi a fumar cigarro por ver lá só na rua, ele já fumava dentro de casa. Lembro até disso, que eu falava: "Pai, fuma dentro do quarto que eu vou acabar fumando. Você vai ver, eu vou fumar!’. E aí... Acabei fumando. [...] Aí eu peguei, comecei a fumar maconha. A gente fumava cigarro dentro de casa. Chegava bêbado às vezes, bêbado. Quando chegava bêbado, eu não tinha medo dele (risos). Eu perdi o medo dele quando ele chegava bêbado, caindo. Ele sempre foi aposentado, sempre aposentado ${ }^{88}$ [...]

Bom, seu eu, no meu ponto de vista, até o momento, hoje, até hoje onde eu me encontro, pra pedra então, eu me seguro. Porque não tô nem embalado aqui pra usar crack. O álcool eu acho um pouco difícil..."

Entrevistado P2

"Porque meu pai e mãe são falecidos. Minha mãe faleceu eu tinha seis anos, meu pai eu tinha nove. Meus pais também eram dependentes do back e eles

\footnotetext{
${ }^{88} \mathrm{Ah}$, me batia com razão, sim. Não lembro muito. Com razão. Muitas vezes batia sem nada. Ele batia na minha mãe, porque a minha mãe falava que... Minha mãe chegava do serviço, à noite em casa; e ele lá em casa - ele já era aposentado, desde quando eu me lembro, ele sempre foi aposentado e novo. Porque a gente, quando eu me lembro, com sete anos de idade, ele já era aposentado e ele pegava várias latas; o pessoal gostava de pegar ele pra trabalhar no serviço de pedreiro. Ele pegava concreto e tal. Um cara bem forte; disposição, assim. Mas até onde eu me lembro, era aposentado e era um cara forte. Aí a minha mãe chegava em casa... Eu lembro, foi uma vez só, sabe? Duas. Vamos falar duas. Uma que a minha mãe chegava em casa, e ele começava a brigar com ela. Sempre caçava assunto com ela ou alguma coisa assim. E ela pegava e falava: "Filho, ele está assim por causa de café. Está sem café e sem cigarro. Vai lá, compra cigarro pra ele, um maço de cigarros para ele". Aí eu acho que ela começou a falar isso aí duas vezes já antes. Aí teve um dia que eu me invoquei, eu tinha uns sete anos mais ou menos, sete para oito anos, aí ela chegou em casa para descansar e tal, cansadona porque ela saía de manhã, trabalhava de faxineira, diarista, saía de manhã e voltava à noite - sei lá. Ele começava a brigar por nada. Começava a caçar assunto. Começava a brigar mesmo. Começavam a falar merda e caçar assunto. E eu já ficava experto na porta, para correr, "qualquer coisa ela corre". Qualquer coisa ela corria, na porta, saía correndo. Ela já sabia que ele batia. Aí beleza, aí sumia e não falava pra ele. Às vezes dormia na casa do vizinho. Raramente na casa do vizinho. Às vezes esperava ele se acalmar. Ficava ela lá na rua, sentada na guia, até ele se acalmar, pra ela dormir, entrar, deitar, fazer comida, dormir, pra chegar no outro dia e ir trabalhar cedo. Levantar cedo pra ir trabalhar. E aí ela pegava e falava: "Vai filho, tá com certeza sem cigarro e sem café. Compra lá para ele; compra lá para ele", quando ela tinha o dinheiro. "Compra pra ele" e tal. Eu falei: "Não, mãe, o quê? Faz isso não. Não faz o gosto dele não", falava para ela. "Faz o gosto dele não". Não queria fazer o gosto dele. "Não faz o gosto dele não". Às vezes ele chegava em casa... Teve uma vez que ele chegou lá, ela desceu..., ela desceu o bairro correndo, ele jogou um bloco bem na cabeça dela, nas costas dela. Jogou assim: vupt. Por nada. De graça! Tudo! A maioria das coisas! Tudo de graça! Minha mãe não dava motivo pra ele. Tudo de graça! Todo mundo gostava dela, não conversava com ele. Não conversavam muito com ele não. Até que um dia, eu tinha uns doze anos, eu falava merda pra minha mãe pra não... Eu com doze anos. (Entrevistado P2).
} 
morreram por causa da AIDS. Porque usavam agulha, né? Eu comecei a usar droga com 17 anos. Comecei a fumar maconha e depois cocaína. Aí eu amiguei, tive meu filho Kevin e aí eu sosseguei um pouco. Aí depois eu terminei com ele, que ele me traiu, e eu tive uma depressão. Aí deixei meu filho com a mãe do meu ex-marido. Aí ela cuidou dele pra mim até agora, né? Aí eu comecei, de uns três anos pra cá a usar crack."

\section{Entrevistado P7}

"Mas eu já tinha histórico familiar de uso de drogas [quem usava?] Meu pai, meu irmão mais velho e tive também primos e tal [...] Eu comecei a usar depois que o mеu irmão morreu [...] Morreu com 22 anos [...] de HIV, por droga injetável."

\section{Entrevistado P8}

"Minha mãe era alcoólatra. Minha mãe bebia todo dia e aí depois eu comecei a falar: Pô, ela bebe eu também vou beber. Aí comecei já bebendo. Bebendo, fumando maconha na escola, matando aula e não me dava muito bem com ela. [...]

"Então, eu conheço gente que cheira até hoje e consegue se controlar. Eu já sou diferente. Se eu cheirar, eu já vou querer beber e eu bebo destilado para caramba. Se eu fumar pedra, vou querer beber. Então, é o efeito escadinha. Depois eu vou beber, depois vou usar química, depois vou querer fumar maconha para amenizar tudo e passar a brisa em todas e aí eu faço um coquetel completo."

Entrevistado P11

Nenhum dos usuários entrevistados iniciou a relação com as drogas ilícitas pelo cracke relatam o uso de álcool, droga lícita em nosso ordenamento, como primeira droga de uso ou como concomitante ao uso de todas as drogas ilícitas.

"Não foi, não foi minha primeira droga. Hoje estou com 29 anos; aos 16 anos de idade comecei a fumar maconha, e daí foi cinco anos só usando maconha; e depois teve a substituição por cocaína, cinco anos também direto..., a qual me 
deixou também numa degradação, desleixo, por fim a perca de controle e foi a noiva branca, a cocaína, não é? E daí teve essa perca de controle final da cocaína e... Como não fazia mais a cabeça essa droga, aí eu fui para o crack onde que eu fiz a cabeça e deu maior treta."

\section{Entrevistado P1}

"Eu comecei a usar droga tardiamente, não é? Geralmente na adolescência eu só bebia. Nunca fiz uso de drogas. Eu comecei a usar droga ... Experimentei uma vez só, cocaína, quando eu tinha uns 20 anos, que eu trabalhava no Aeroporto, que é um ambiente que não é muito..."

\section{Entrevistado P3}

“Comecei a fumar maconha com 18 anos. Experimentei. Aí o meu uso contínuo mesmo de maconha foi lá pelos 24 anos. Aí depois fui experimentar cocaína com uns 27 anos. E o uso mais frequente começou com uns 29/30. Com uns 33 já começaram os prejuízos do uso da cocaína com perda de trabalho, problemas familiares, sociais, financeiros, enfim. O crack eu vim usar foi há uns quatro anos atrás, entendeu?”

\section{Entrevistado P4}

"Eu comecei fumando cigarro com 16 anos. Já bebia, mas sempre, até hoje, socialmente. Do cigarro, com 16 anos, eu experimentei maconha. Daí eu experimentei a cocaína e nesse meio termo, com 16/17 anos na Faculdade eu usei lança, cocaína, menos o crack. Lá eu não usei o crack. E na mesma época da faculdade, mas fora da Faculdade com alguns amigos, eu experimentei o crack e daí em diante, com mais ou menos 18 até hoje os 26 anos, eu tô nessa."

\section{Entrevistado P5}

"Então, eu comecei a usar cigarro primeiro, com 11 anos de idade. Aí com álcool e depois com 12 anos comecei a tomar bebida alcóolica, comecei a tomar álcool e com 13 anos eu experimentei a maconha. Aí de lá foi só me matando. Aí com uns 15 anos eu comecei a usar cocaína, que era a pasta base que é cocaína e aí com 17/18 anos comecei a usar pedra até uns 40 dias atrás." 


\section{Entrevistado P6}

"Eu comecei a usar droga com 17 anos. Comecei a fumar maconha e depois cocaína."

Entrevistado P7

"Acho que foi em volta de 12 para 13 anos, com solventes, cola de sapateiro..."

Entrevistado P8

“Então, eu comecei... Eu não bebia, não fumava. Comecei a beber. Aí com 24 anos eu conheci a droga, a cocaína. Maconha eu nunca fumei."

Entrevistado P9

"Ah, eu sou dependente química desde os 13. Comecei fumando maconha com 13 para 14. Depois eu comecei a cheirar cocaína com 15. Depois eu conheci o crack com 17 e as outras drogas, LSD, balas essas coisas, com 18. [...]Aí comecei já bebendo. Bebendo, fumando maconha na escola..."

Entrevistado P11

Outro aspecto que não tem relação com as propriedades farmacológicas da substância, mas pode ser visto como ensejador das políticas específicas é o fato de que o uso do crack, em algumas grandes cidades, se desenvolveu em ambientes centrais e desprotegidos e não no contexto restrito às favelas.

Essa visibilidade, aliada ao padrão de uso compulsivo, que leva o indivíduo a um esgotamento físico e psicológico, gerando um descaso com cuidados básicos de saúde, 
alimentação, e higiene pessoal ${ }^{8990}$, despertou "na mídia, na sociedade em geral e nos políticos uma perplexidade que antes não existia" ${ }^{\prime 91}$.

Visualmente incômodos, os subgrupos de usuários que chamam a atenção do público em geral pelo estado de deterioração dos indivíduos usuários e o uso é constantemente relacionado à violência, geram pressões políticas para o combate duro e eficaz da droga.

"Por exemplo, você pega um usuário de crack. Você pergunta para qualquer pessoa na rua, o que ele vai pensar: "Deus me livre. Está quase em condição de uma pessoa excluída socialmente, a maior parte fica em situação de rua, fica naquelas casas abandonadas. Vem aquela imagem meio que parece caracterizada como mendigo. Se arrastando pela rua."

\section{Entrevistado E5}

Ademais, estudos relacionados ao papel da mídia em relação às drogas no geral $^{92}$, bem como especificamente em relação ao $\operatorname{crack}^{93}$ demonstram que a mídia seleciona acontecimentos que refletem o pensamento vigente, aprofundando pouco as considerações sobre o tema e, no geral, reforçando as relações de dominação e o preconceito estigmatizantes relacionado a essas substâncias.

“[...] a mídia faz com que a população associe o crack à situação de vulnerabilidade social, às cracolândias, à situação de indigência, à miséria social mesmo. Então fica muito associado o crack a essa situação, quando a gente sabe que tem pessoas de outro nível também que são dependentes de crack,

\footnotetext{
${ }^{89}$ RIBEIRO, LA; SANCHEZ, ZM; NAPPO, AS. Surviving crack: a qualitative study of the strategies and tactics developed by Brazilian users to deal with the risks associated with the drug. BMC Public Health, v.10, p.671, 2010.

${ }^{90}$ Embora o consumo de crack ainda implique, frequentemente, padrões mais graves de dependência, alguns estudos de acompanhamento tem demonstrado que existem usuários que usam a droga de modo controlado, de forma menos frequente, até eventual. Há também relatos de pessoas que usam a droga há mais de dez anos e outros que foram diminuindo a intensidade do uso com o passar do tempo. RIBEIRO, Marcelo; LARANJEIRA, Ronaldo. $O$ tratamento do usuário de crack. São Paulo: Artmed, 2012, p. 211.

${ }^{91}$ FUNDAÇÃO OSWALDO CRUZ. Revista Poli: Saúde, Educação e Trabalho. Ano V, n.24, jul/ago, 2012 p. 18.

${ }^{92}$ SILVA, Gilberto Lucio da (Org.). Drogas: Políticas e práticas. São Paulo: Roca, 2011.

93 ROMANINI, Moises; ROSO, Adriane. Mídia e crack: promovendo saúde ou reforçando relações de dominação?. Psicol. cienc. prof. - online, v.32, n.1, pp. 82-97, 2012.
} 
só atualmente tem 3 médicos aqui que são dependentes de crack, meus pacientes. E são pessoas que têm filhos, têm família, têm emprego. Não que eles estejam bem, eles não estão bem, mas não tem nada a ver com aquela situação da cracolândia. Então eu acho que é por conta de preconceito mesmo”.

Entrevistado P15

Essa tendência verificada na difusão da informação pela mídia leva também a outra associação que, embora não corresponda à realidade, acaba convencendo a população que, temerosa, clama por políticas incisivas em relação aos usuários de crack: a associação do uso da droga com a violência.

"Acho que a forma como o governo está fazendo está dando medo na gente. A gente está ficando cada vez com mais medo e o medo não é uma coisa positiva. Ter medo das coisas não faz a gente ficar mais atenta, mais alerta. A gente tem que estar conscientizado das coisas e não com medo das coisas. E a gente tem medo do crack e a gente não está conscientizado do crack, não é?"

Entrevistado E10

Deve-se atentar para o fato de que a violência está mais associada com o fenômeno sistêmico gerado pela proibição das drogas - o que viabiliza a existência do tráfico e a violência a ele associada - do que ao comportamento violento por parte dos usuários. No que toca à forma de manutenção do vício, diferentemente da propaganda midiática, atividades ilícitas, como o tráfico de drogas, furtos e roubos, são relatadas pela minoria dos usuários, cerca de $6,4 \%$ para o tráfico e $9,0 \%$ para os crimes patrimoniais ${ }^{94}$.

"Veja, a questão, assim, não é porque você usa crack que você vai ser mais violento. Esse comportamento de violência já tem em você. Então, não vamos dizer que todo usuário de crack é bandido. Não é essa a questão. Mas é claro

\footnotetext{
${ }^{94}$ FUNDAÇÃO OSWALDO CRUZ. Estimativa do número de usuários de crack e/ou similares nas Capitais do País. Livreto epidemiológico. Disponível em: <http://portal.fiocruz.br/pt-br/content/maiorpesquisa-sobre-crack-j\%C3\%A1-feita-no-mundo-mostra-o-perfil-do-consumo-no-brasil>. Acesso em: 14 de janeiro de 2014.
} 
que seus limites, seus bordos ficam um pouco mais abertos em função da premência do uso."

Entrevistado E3

Paul J. Goldstein ${ }^{95}$, em artigo sobre o nexo entre o uso de drogas no geral e a violência estabelece um conceito tripartido. Segundo o autor, o uso de drogas e a violência podem ser relacionados de três maneiras, quais sejam: (a) o efeito farmacológico das substâncias, (b) a motivação econômica relacionada à compulsão pelo uso da droga e, (c) a violência sistêmica.

A relação farmacológica é aquela que pode ser atribuída aos efeitos produzidos pela droga no organismo. Assim, uma pessoa que agride sexualmente a vítima em virtude de, embriagado, ter entendido mal os sinais de sedução e encontrar-se mais desinibido. Ainda, como exemplo clássico, podem ser citados os acidentes de trânsito cometidos por pessoas que ingeriram álcool antes de dirigir.

A "motivação econômica" é aquela cometida pelo indivíduo com o objetivo de angariar fundos para custear o uso da droga. Relaciona-se, principalmente, à prática de crimes contra o patrimônio, podendo, também, ser ligada à práticas de crimes mais violentos. As drogas com alto poder de gerar dependência, como o crack, tem, no geral, um padrão de uso compulsivo ${ }^{96}$, o que tornaria seus usuários os principais autores desses delitos. A despeito do retro afirmado, um estudo americano demonstrou que, de todos os presidiários usuários frequentes de cocaína e crack, somente 39\% admitiram ter cometido o crime para financiar seu envolvimento com a droga ${ }^{97}$.

Não obstante separados pelo autor, o efeito farmacológico e a motivação econômica são intimamente relacionados. De fato, a necessidade do uso é também um dos efeitos causados pela droga no organismo, razão pela qual torna-se possível colocá-los num mesmo plano. Assim, restariam as manifestações de violência sistêmica.

\footnotetext{
${ }^{95}$ GOLDSTEIN, Paul J. The Drugs/Violence Nexus: A Tripartite Conceptual Framework. Journal of Drug Issues, v.39, p.143-174, 1985.

96 OLIVEIRA, Lúcio Garcia; NAPPO, Solange Aparecida. Caracterização da cultura de crack na cidade de São Paulo. Padrão de uso controlado. Revista de Saúde Pública, 2008.

${ }^{97}$ MINAYO, Maria Cristina de Souza. A complexidade das relações entre drogas, álcool e violência. Caderno de Saúde Pública, Rio de Janeiro, 1998, p. 2.
} 
A violência sistêmica nada mais é do que o conjunto de manifestações violentas relacionadas com o âmbito do ilícito criado por uma política de proibição absoluta de certas substâncias. No exato momento em que se proíbe alguma droga, todos os indivíduos direta ou indiretamente relacionados à elas são alçadas à condição de criminosos. "A violência se torna uma estratégia para disciplinar o mercado e os subordinados (...) o narcotráfico potencializa e torna mais complexo o repertório das ações violentas e a delinquência organizada". 98

Cumpre ainda salientar que os estudos destinados a estabelecer com maior precisão o nexo existente entre o uso de determinadas drogas e a violência encontra obstáculos na imensa gama de variáveis que deveriam ser observadas para que se obtivessem resultados de valor. Mesmo que haja um número significativo de presos que relatem o consumo de drogas antes do evento criminoso, é difícil constatar qual o peso do uso da droga na prática do crime quando consideradas outras variáveis como nível socioeconômico, escolaridade, presença de comorbidades, uso isolado ou concomitante de substâncias, dentre outras.

Portanto, das três formas de associação entre drogas e violência, a única certa é a violência sistêmica: se não há como afirmar que, necessariamente, o uso de drogas leve ao crime, é certo que a proibição cria uma nova e imensa categoria de criminosos. Disso se depreende que a reação do senso comum provocada pelo alarde da mídia sobre a questão do crack deveria, em verdade, incitar à reflexão em relação à quanto a adoção das políticas repressivas pode, ao invés de diminuir a violência, aumenta-la significativamente.

Comovendo e assustando o conjunto dos participantes de nossas sociedades contemporâneas, o medo da criminalidade provoca a busca dos rigores da repressão, da maior intervenção do sistema penal - alternativa tão palpável quanto irreal de solução de problemas de satisfação de desejos de proteção, tranquilidade e segurança. ${ }^{99}$

Como bem se sabe, a opção por determinada política criminal não se opera somente em função dos estudos científicos elaborados sobre o tema, senão também, e, por que não

98 MINAYO, Maria Cristina de Souza. A complexidade das relações entre drogas, álcool e violência. Caderno de Saúde Pública., p.2, Rio de Janeiro, 1998.

${ }^{99}$ KARAM, Maria Lúcia. Drogas: a irracionalidade da criminalização. Boletim do Instituto Brasileiro de Ciências Criminais. Ed. Especial nº 45. São Paulo: IBCCrim, p. 9, 1996. 
dizer, até preponderantemente, em função das pressões sociais existentes. Como diz Zaffaroni: "os políticos desapoderados não tem resposta, mas seu espetáculo deve continuar" ${ }^{100}$, e completa:

Como o estado desapoderado dos países que levam a pior parte na globalização, não se pode resolver os problemas sociais sérios, seus políticos optam por simular que resolvem esses problemas, ou que sabem como solucioná-los, tornam-se maneiristas, afetados, a política converte-se num espetáculo e o estado mesmo também converte-se num espetáculo. Os políticos - presos na natureza competitiva de sua atividade - deixam de buscar o melhor para preocupar-se só com o que possa transmitir-se melhor e aumentar sua clientela eleitoral. ${ }^{101}$

Para que se fortaleça, portanto, a influência dos estudos acadêmicos no direcionamento da política criminal adotada, é necessário que haja pesquisas capazes de elucidar pontos ainda obscuros concernentes ao crack, bem como que os resultados sejam suficientemente divulgados a ponto de minimizar o preconceito e garantir a pressão popular no sentido de que sejam assegurado aos usuários não só do crack, mas de todas as drogas, que sejam tratados como os cidadãos que são, e não como sobras da sociedade, evitando que a ignorância resulte na adoção de políticas que aprofundam a raiz do problema.

100 ZAFFARONI, Eugenio Raul; OLIVEIRA, Edmundo. Criminologia e Política Criminal. Rio de Janeiro: GZ Editora, 2010. p.175.

${ }^{101}$ Ibidem, p.34. 


\section{A Lei de Drogas e o Bem o Bem Jurídico Tutelado}

O Direito Penal é o ramo do direito que se ocupa da proteção dos bens jurídicos indispensáveis a uma convivência harmoniosa em sociedade. Bens jurídicos são os valores considerados fundamentais em determinada sociedade, como por exemplo, a vida, a integridade, a intimidade, etc.

Não deve, no entanto, o direito penal se ocupar de todas as lesões ou ameaças de lesão a bens jurídicos, uma vez que, às mencionadas violações, apresenta respostas também violadoras desses mesmos bens, tendo, como exemplo máximo, a pena de prisão, que vai de encontro ao bem jurídico liberdade. Como leciona Zaffaroni:

\footnotetext{
A constatação de que a solução punitiva sempre importa num grau considerável de violência, ou seja, de irracionalidade, além da limitação de seu uso, impõe-se, na hipótese em que se deva lançar mão dela, a redução, ao mínimo, de sua irracionalidade. ${ }^{102}$
}

É por este motivo que o direito penal só deve ser instado quando nenhum outro ramo do direito se mostrar capaz de combater as mencionadas lesões, ou ameaças de lesão. Tratase de tutela subsidiária e não principal.

Em tese, o bem jurídico que se tutela pela Lei de Drogas é a saúde pública. Logo, a lesão, ou ameaça de lesão, poderia ser concebida tanto como a facilitação da circulação dessas substâncias proibidas, quanto como a lesão à saúde pública pelo aumento no número de usuários do sistema de saúde em virtude dos danos causados pelas drogas.

Segundo Vicente Greco Filho, “o bem jurídico protegido pelo direito é a saúde pública. A deterioração causada pela droga não se limita àquele que a ingere, mas põe em risco a própria integridade social" "103. Segundo Luiz Flavio Gomes, o bem jurídico protegido

\footnotetext{
${ }^{102}$ PIERANGELI, José Henrique; ZAFFARONI, Eugênio Raul. Manual de Direito Penal Brasileiro. v.1: Parte Geral. 8 ed. São Paulo: Revista dos Tribunais, 2010. p.56.

${ }^{103}$ GRECO FILHO, Vicente; RASSI, João Daniel. Lei de Drogas Anotada. Lei n ${ }^{\mathbf{0}}$ 11.343/06. 3 ed. São Paulo: Saraiva, 2009. p.86.
} 
de forma imediata seria a saúde pública, enquanto de forma mediata estariam protegidos a vida, a integridade física, a saúde, etc. ${ }^{104}$

Por meio dos crimes previstos na legislação específica, o legislador intentou criminalizar todas as ações relacionadas ao ciclo da droga. Trata-se uma abordagem ominicompreensiva $^{105}$. A lei, portanto, atua em duas frentes repressivas, em relação ao usuário e em relação ao traficante.

No tocante ao crime de tráfico de drogas, seria possível perceber de que forma as ações descritas no tipo penal representam essa lesão, ou ameaça, uma vez que é o próprio tráfico que viabiliza a circulação dessas substâncias, colocando em risco a saúde pública ${ }^{106}$.

Com relação à criminalização do porte para uso pessoal, argumentam os favoráveis à criminalização que independentemente do uso ou da quantidade apreendida, o simples porte da substância proibida colocaria em risco a saúde pública, pois facilitaria a circulação da droga, contribuindo para a propagação do uso ${ }^{107}$.

Desse posicionamento, Vicente Greco Filho afirma:

\begin{abstract}
A razão jurídica da punição daquele que adquire, guarda, tem em depósito, transporta ou traz consigo para uso próprio é o perigo social que sua conduta representa. Mesmo o viciado, quando traz consigo a droga, antes de consumi-la, coloca a saúde pública em perigo, porque é fator decisivo na difusão dos tóxicos. O toxicômano normalmente acaba traficando, a fim de obter dinheiro para aquisição da droga, além de estar psicologicamente estar predisposto a levar outros ao vício, para que se compartilhem ou de seu paraíso artificial ou de seu inferno ${ }^{108}$.
\end{abstract}

${ }^{104}$ GOMES, Luiz Flávio (Org.). Lei de Drogas Comentada. Lei no 11.343/06. 3 ed. São Paulo: Revista dos Tribunais, 2008. p.135.

${ }^{105}$ CARVALHO, Salo. A Política Criminal de Drogas no Brasil: Estudo criminológico e dogmático da Lei $\mathbf{n}^{\mathbf{0}}$ 11.343/06. 6 ed. São Paulo: Saraiva, 2013. p.455.

${ }^{106}$ Como contraponto, deve-se atentar para o fato de que, no caso da legalização de todas as drogas, o tráfico deixaria de existir, sendo possível afirmar que elemento indispensável para a existência do tráfico de drogas é a própria proibição ao cultivo e comercialização das drogas. Sem a proibição, estaria extinto o tráfico.

${ }^{107}$ Nesse sentido, conferir GRECO FILHO, Vicente; RASSI, João Daniel. Lei de Drogas Anotada. Lei $\mathbf{n}^{\mathbf{0}}$ 11.343/06. 3 ed. São Paulo: Saraiva, 2009. p.86 e MENDONÇA, Andrey Borges; CARVALHO, Paulo Roberto Galvão (Org.). Lei de Drogas: Lei 11.343, de 23 de agosto de 2006. Comentada artigo por artigo. 3 ed. São Paulo: Método, 2012.

${ }^{108}$ GRECO FILHO, Vicente; RASSI, João Daniel. Op. Cit. p. 47. 
Ainda assim, Andrey Borges de Mendonça ${ }^{109}$ :

(...) é uma falácia imaginar que no porte de droga para consumo pessoal haveria lesão apenas ao bem jurídico do usuário e que o único interesse lesionado seria o seu. Há, em verdade, um evidente perigo de lesão ao bem jurídico tutelado, de natureza difusa, ou seja, titularizado por toda a sociedade, que é a saúde pública.

Ao fim e ao cabo, sem os usuários, restaria esvaziado o mercado do tráfico. Sem procura, seria o fim da oferta. Por fim, a proibição dessas substâncias seria um contra incentivo ao seu uso, significando também uma proposta preventiva, posto que suficiente para diminuir a difusão do uso de drogas e uma proteção da vida e da integridade física desses indivíduos.

A esse posicionamento, no entanto, contrapõe-se parte considerável da doutrina, que argumenta tanto que a proibição só aumenta a incerteza e o descontrole sobre as substâncias que consomem esses indivíduos, aumentando os danos à saúde decorrentes do uso, quanto pela inconstitucionalidade do tipo previsto no artigo 28 da Lei de Drogas.

Esses aspectos práticos e teóricos que contrariam a criminalização do porte de drogas para consumo pessoal refletem a tese com a qual concorda esta pesquisa. Considerando, no entanto, não ser este o enfoque do presente trabalho, far-se-á apenas um breve apanhado das ideias que fundamentam a referida posição.

Sobre o argumento de que a criminalização do uso protege, de alguma maneira, a vida e a integridade física dos usuários é fácil perceber que a clandestinidade importa em absoluta falta de controle acerca da composição da droga consumida, bem como da quantidade do princípio ativo, o que incrementa o risco de overdose e de contaminação por outras substâncias desconhecidas. Ademais, o contexto de ilegalidade em que são inseridos os consumidores implicam, obviamente em maiores riscos. Para usarmos como exemplo o crack, o trecho transcrito a seguir demonstra com clareza o circuito de violência em que são inseridos os usuários em virtude da criminalização:

${ }^{109}$ MENDONÇA, Andrey Borges de; CARVALHO, Paulo Roberto Galvão (Org.). Lei de Drogas: Lei 11.343, de 23 de agosto de 2006. Comentada artigo por artigo. 3 ed. São Paulo: Método, 2012. 


\begin{abstract}
A violência que se verifica nas bocas é acentuada pela decisão mercadológica de comercializar o crack. Os dados obtidos permitem concluir que o mercado do crack tende a disseminar a violência nas regiões onde predomina, incrementando a incidência de roubos e, principalmente, de homicídios. $\mathrm{O}$ aspecto farmacológico da droga interfere no fenômeno à medida que cria um contingente expressivo de consumidores compulsivos, em magnitude superior àquele observado no comércio das demais drogas ilícitas prevalecentes na sociedade brasileira. Consumidores compulsivos e, por que não dizer, vítimas da dependência química, tendem a se tornar mais endividados com seus fornecedores, e tais dívidas, se não forem pagas após um certo tempo, tendem a resultar em homicídio dos devedores. (g.n.) $)^{110 "}$
\end{abstract}

Difícil pensar outro contexto senão o da criminalidade em que a dívida seja convertida em morte.

Outro ponto, citado por Mariana de Assis Brasil e Weigert ${ }^{111}$ é que o contexto de marginalidade em que é inserido o uso da droga pode influenciar na busca por substâncias cujos efeitos são produzidos mais rapidamente, a fim de evitar o flagrante com a droga, o que aumentaria o número de usuários dessas drogas mais danosas ao organismo ${ }^{112}$.

Muito embora com ressalvas em relação a esta tese, já que o crack, droga de uso compulsivo, tem seu consumo relatado como ininterrupto por vários dias o que de forma nenhuma serviria para evitar o flagrante policial, vale o registro da crítica. Importa ressaltar, ademais, que embora o raciocínio tenha sido exposto na obra em termos gerais, o autor citado na conclusão do texto é espanhol e a menção direta se faz à drogas injetáveis, pelo que, o contexto descrito pode se diferenciar do brasileiro.

No plano teórico, a doutrina argumenta sobre a ofensa aos princípios constitucionais da intimidade e da vida privada, à medida que com a proibição do porte para uso pessoal o Estado atuaria em âmbito resguardado da ingerência desse poder, bem como ao princípio da

\footnotetext{
${ }^{110}$ RIBEIRO, Marcelo; LARANJEIRA, Ronaldo. O tratamento do usuário de crack. São Paulo: Artmed, 2012. p. 90.

${ }^{111}$ Advogada. Possui graduação em Direito pela Pontifícia Universidade Católica do Rio Grande do Sul (2005). É mestre em Criminologia e Execução Penal pela Universidad Autónoma de Barcelona (2007) e também é mestre em Ciências Criminais pela PUCRS (2008) com estudo sobre A Criminalização do Uso de Drogas e a Expansão do Punitivismo no Brasil. É doutoranda em Psicologia Social e Institucional pela UFRGS e professora de Direito Penal e Criminologia no Centro Universitário Ritter dos Reis - UniRitter (graduação e pós-graduação). Disponível em:

<http://buscatextual.cnpq.br/buscatextual/visualizacv.do?metodo=apresentar\&id=K4776810J4>. Acesso em: 25 dez. 2013.

112 WEIGERT, Mariana de Assis. Brasil. Uso de Drogas e Sistema Penal: Entre o proibicionismo e a redução de danos. Rio de Janeiro: Lumen Juris, 2010. p.86
} 
igualdade, uma vez que a diferenciação entre substâncias lícitas e ilícitas - e, portanto, a diferenciação entre condutas criminosas ou não - não se funda em critérios científicos aceitáveis, estando a distinção de tratamento alicerçada apenas em padrões morais ${ }^{113}$.

O Direito Penal, com suas sanções mais duras, somente poderia abranger os âmbitos nos quais os outros ramos do direito, que preveem consequências mais leves do que a pena corporal, não fossem suficientes para conter ou reparar a violação da lei que afete os bens jurídicos protegidos. A proteção operada pelo direito penal é subsidiária, pois deve entrar em ação somente quando outros ramos do direito não forem suficientes para conter as mencionadas violações.

Portanto, não é possível (ou não deveria ser possível), a criminalização de condutas que não afetem bens jurídicos de terceiros, uma vez que a auto-lesão não interessa (ou não deveria interessar) ao ordenamento jurídico penal ${ }^{114}$. Veja-se, a esse exemplo, a lesão corporal, somente punida quando provocada em terceiro, ou o suicídio, não inserido no campo do ilícito, sendo criminalizáveis somente as condutas a ele relacionadas, quais sejam, incitação, auxílio ou induzimento.

A incriminação do porte de drogas para uso pessoal feriria também o princípio constitucional da ofensividade, consagrado pelo artigo $5^{\circ}, \mathrm{XXXV}$, da Constituição Federal, que limita a esfera de incidência das proibições penais somente àquelas condutas que importem efeitos danosos à terceiros.

Ainda pende de julgamento pelo Supremo Tribunal Federal (STF)o Recurso Extraordinário que discute a constitucionalidade do artigo 28 da Lei de Drogas ${ }^{115}$. O STF analisará a validade do dispositivo diante dos direitos fundamentais a intimidade e à vida

\footnotetext{
113 WEIGERT, Mariana de Assis. Brasil. Uso de Drogas e Sistema Penal: Entre o proibicionismo e a redução de danos. Rio de Janeiro: Lumen Juris, 2010, p.83.

114 PIERANGELI, José Henrique; ZAFFARONI, Eugênio Raul. Manual de Direito Penal Brasileiro v.1: Parte Geral. 8 ed. São Paulo: Revista dos Tribunais, 2010. p. 40.

${ }^{115}$ BRASIL. Supremo Tribunal Federal. Acompanhamento processual. Recurso Extraordinário no 635.659. Disponível em:

<http://www.stf.jus.br/portal/processo/verProcessoAndamento.asp?incidente=4034145>. Acesso em:

31 jan. 2013.
} 
privada, bem como frente à necessidade de que, para ser tutelada pelo Direito Penal, a conduta empreendida pelo agente lesione bens de terceiros.

Conforme já se aduziu, o direito penal exerce proteção subsidiária dos bens jurídicos e deve ser acionado somente quando os outros ramos do direito não forem capazes de conter a violação, exercida ou iminente. O uso de drogas para consumo próprio, para aqueles que defendem sua inconstitucionalidade, não lesiona bem jurídico de terceiro, ao passo que significa prejuízo apenas e tão somente para o usuário, bem como, também por esta razão, viola os direitos fundamentais à liberdade, intimidade e vida privada.

Para os que advogam pela inconstitucionalidade, criminalizar o uso de drogas seria tolher os cidadãos adultos e capazes da possibilidade de, livres, fazerem suas escolhas. Responsabilizá-los pela circulação das substâncias seria atribuir-lhes uma sanção pela conduta dos traficantes e utilizá-los para reforçar o estímulo negativo ao uso de drogas seria instrumentalizá-los, em violação clara ao princípio da dignidade da pessoa humana.

No entanto, até que o Plenário do Supremo se manifeste sobre o tema, permanecem válidos os tipos penais previstos na Lei de Drogas, pelo que, daremos continuidade a análise de suas peculiaridades e de alguns dos institutos processuais a eles relacionados, antes de adentrarmos à discussão que serviu de mote à pesquisa, qual seja, qual o impacto do exercício da repressão penal sobre o usuário na busca pelo tratamento.

\subsection{A EvoluÇão da Criminalização do USUÁrio de Drogas}

A relação simbiótica da política em torno dos delitos e das penas continua um desafio em face do contexto de aprofundamento tanto da desconfiança, que aniquila a compreensão, bem como da indiferença, que inviabiliza a solidariedade. ${ }^{116}$

No Brasil, a posse ilícita de entorpecentes foi criminalizada pela primeira vez em 1932 (Dec. $\mathrm{n}^{\mathrm{o}} 20.930$, de 11.01.1932 ${ }^{117}$ ) e, graças aos acordos internacionais sobre o tema,

\footnotetext{
116 ZAFFARONI, Eugenio Raul; OLIVEIRA, Edmundo. Criminologia e Política Criminal. Rio de Janeiro: GZ Editora, 2010. p.4.

${ }^{117}$ BRASIL. Decreto $n^{\circ}$ 20.930/32. Fiscaliza o emprego e o comércio das substâncias tóxicas entorpecentes, regula a sua entrada no país de acordo com a solicitação do Comité Central Permanente do Opio da Liga das
} 
bem como ao golpe militar de 1964, prevaleceu no país, até 2006, o modelo bélico de guerra às drogas como política criminal ${ }^{118}$, prevendo a aplicação de pena de prisão também ao usuário.

A Lei $n^{\circ} 6.368 / 76^{119}$, pouco alterou, no que se refere à sua ideologia, o sistema que já se verificava desde a época da ditadura, mas representou avanço significativo ao passo que tipificou a conduta do usuário e do traficante em artigos distintos. Enquanto o tráfico de drogas encontrava-se previsto no artigo 12, com pena que variava entre três e cinco anos, a conduta de adquirir, guardar ou ter consigo, para uso próprio, substância entorpecente, vinha prevista no artigo 16 e, embora ainda trouxesse a previsão de pena restritiva de liberdade, o fazia em menor quantidade. Vejamos:

Art. 16. Adquirir, guardar ou trazer consigo, para o uso próprio, substância entorpecente ou que determine dependência física ou psíquica, sem autorização ou em desacordo com determinação legal ou regulamentar:

Pena - Detenção, de 6 (seis) meses a 2 (dois) anos, e pagamento de (vinte) a 50 (cinqüenta) dias-multa (grifo nosso).

Da mesma maneira que ocorre hoje, a Lei $\mathrm{n}^{\circ} 6.368 / 1976$ punia todas as condutas relacionadas ao ciclo da droga, mas avançou em relação aos diplomas anteriores à medida explicitou a diferença existente entre a conduta empreendida pelo traficante, que efetivamente coloca em circulação à droga, da conduta do usuário, que, pelo seu uso, viabilizaria a continuidade da mercancia e potencializaria o risco de circulação das substancias proibidas.

Nações, e estabele penas. Disponível em: http://www2.camara.leg.br/legin/fed/decret/1930-1939/decreto20930-11-janeiro-1932-498374-publicacaooriginal-81616-pe.html, acessado em 14 de janeiro de 2014.

${ }^{118}$ RIBEIRO, Maurides de Melo. Políticas públicas e a questão das drogas: o impacto da política de redução de danos na legislação brasileira de drogas. 2007. Dissertação (Mestrado em Direito). Universidade de São Paulo, 2007.

${ }^{119}$ BRASIL. Lei no 6368/76. Dispõe sobre medidas de prevenção e repressão ao tráfico ilícito e uso indevido de substâncias entorpecentes ou que determinem dependência física ou psíquica, e dá outras providências. Disponível em: http://www.planalto.gov.br/ccivil_03/leis/16368.htm, acessado em 14 de janeiro de 2014. 
O avanço da redução dos patamares mínimo e máximo da resposta penal também é significativo em termos de proporcionalidade. As condutas relacionadas ao uso de drogas, pelo menor potencial danoso que lhes é peculiar, passou a ser punida com pena privativa de liberdade menor do que aquela aplicada ao tráfico.

Por outro lado, muito embora ainda houvesse a previsão de aplicação da pena privativa de liberdade, na prática, com o advento da Lei $\mathrm{n}^{\circ} 9.099 / 95^{120}$,que instituiu os Juizados Especiais Criminais, e, em 2001, a ampliação do patamar máximo de pena das chamadas infrações de menor potencial ofensivo para dois anos (Lei $n^{\circ} 10.259 / 01^{121}$ ), os usuários de droga passaram a ter a pena corporal substituída pela restritiva de direito graças a possibilidade de realização da transação penal. Sem um exame mais profundo da matéria, relativo ao juízo sobre a diferenciação entre usuários e traficantes, o que pode ensejar a prisão de uns como se outros fossem, ao menos em tese, os consumidores de drogas não eram mais punidos com a pena privativa de liberdade.

Não obstante os resultados práticos já fossem possíveis desde que o crime de porte para uso próprio passou a fazer parte das chamadas infrações de menor potencial ofensivo, a Lei $\mathrm{n}^{\circ} 11.343 / 2006^{122}$ operou avanço ao prever para o usuário sanções diferentes da privação de liberdade.

É que tem significado diferente no campo da Política Criminal a não aplicação da pena de prisão em decorrência da possibilidade de acordo com o órgão acusatório e, consequentemente, a imposição de medida menos gravosa, da não aplicação da pena de prisão em virtude de ter sido ela expressamente rechaçada pelo texto legislativo por não ser considerada como forma ideal de resposta ao fato típico.

\footnotetext{
${ }^{120}$ BRASIL. Lei n ${ }^{\circ}$ 9.099/95. Dispõe sobre os Juizados Especiais Cíveis e Criminais e dá outras providências. . Disponível em: <http://www.planalto.gov.br/ccivil_03/leis/19099.htm>. Acesso em: 05 jan. 2014.

${ }^{121}$ BRASIL. Lei ${ }^{\circ}$ 10.259/01. Dispõe sobre a instituição dos Juizados Especiais Cíveis e Criminais no âmbito da Justiça Federal. Disponível em: <http://www.planalto.gov.br/ccivil_03/leis/leis_2001/110259.htm>. Acesso em: 05 jan. 2014.

${ }^{122}$ BRASIL. Lei $n^{\circ}$ 11.343/06. Institui o Sistema Nacional de Políticas Públicas sobre Drogas - Sisnad; prescreve medidas para prevenção do uso indevido, atenção e reinserção social de usuários e dependentes de drogas; estabelece normas para repressão à produção não autorizada e ao tráfico ilícito de drogas; define crimes e dá outras providências. Disponível em http://www.planalto.gov.br/ccivil_03/ato20042006/2006/lei/111343.htm, acessado em 14 de janeiro de 2014.
} 
Ademais, a Lei $\mathrm{n}^{\mathrm{o}} 11.343 / 2006$ difere substancialmente dos diplomas legais anteriores à medida que deixa de ter como finalidade apenas as medidas de repressão ao uso de entorpecentes, para estabelecer, já em seu artigo primeiro, o objetivo de criação do Sistema Nacional de Políticas Públicas sobre Drogas - SISNAD, com atuação voltada para prevenção do uso indevido, atenção e reinserção social de usuários e dependentes de drogas e estabelecimento de normas para repressão à produção não autorizada e ao tráfico ilícito de drogas.

Segundo Luciana Boiteux:

\begin{abstract}
A Nova Lei de Drogas (n. 11.343/06) avançou ao despenalizar o usuário, ou seja, ao impedir que àquele se apliquem penas de prisão, na forma do seu art. 28, que somente prevê medidas alternativas. Tal legislação inovou também na positivação de princípios importantes, tais como o fortalecimento da autonomia e da responsabilidade individual em relação ao uso indevido de drogas (art. 19, III) e a reafirmação dos princípios da liberdade e da diversidade (art. $4^{\circ}$ ), além do reconhecimento oficial das políticas de redução de danos. ${ }^{123}$.
\end{abstract}

Como se pode observar, a norma determina, expressamente, que as políticas públicas deverão ser traçadas para a atenção e reinserção social dos usuários e reconhece expressamente a interdisciplinaridade da matéria e a necessidade de cooperação das diversas áreas do conhecimento.

Muito embora o discurso tenha evoluído, a mentalidade dos operadores do sistema parece ter permanecido atrelada ao discurso maniqueísta mais vinculado à lógica estritamente repressiva da legislação anterior, até porque, ao que parece, os objetivos declarados pela lei, quais sejam, a atenção e reinserção social do usuário, não conversam o punitivismo relacionado ás suas ações. Num contexto de atenção, a relação é horizontalizada, enquanto a repressão penal se desenvolve, necessariamente, pela imposição da força estatal sobre o indivíduo.

Essa discussão importa à medida que a alteração quantitativa nas sanções revistas abstratamente às ações referentes ao usuário podem levar à falsa sensação de sobre eles não

\footnotetext{
${ }^{123}$ BOITEUX, Luciana. Breves considerações sobre a política de drogas brasileira atual e as possibilidades de descriminalização. Boletim IBCCRIM, São Paulo, v.18, n.217, p.16, dez. 2010.
} 
pesa mais o peso da criminalização de suas condutas. Ao traçar objetivos, a norma precisa valer-se dos mecanismos aptos à consecução do fim desejado.

Explica-se. No seu artigo $1^{\circ}$, a Lei ${ }^{\circ} 11.343 / 2006$ dispõe:

Art. $1^{\circ}$ Esta Lei institui o Sistema Nacional de Políticas Públicas sobre Drogas Sisnad; prescreve medidas para prevenção do uso indevido, atenção e reinserção social de usuários e dependentes de drogas; estabelece normas para repressão à produção não autorizada e ao tráfico ilícito de drogas e define crimes (g.n.).

A reforçar a ideia de atenção ao usuário, a legislação vigente inclui o artigo que tipifica a conduta de porte para uso pessoal de drogas no Título relativo às "Atividades de Prevenção do Uso Indevido, Atenção e Reinserção Social de Usuários e Dependentes De Drogas”.

Numa leitura menos atenta, poder-se-ia supor que "o usuário já não pode ser chamado de "criminoso""124, ou que "A Lei assentiu a ideia de que o uso de drogas não é uma questão primordialmente de 'polícia', mas sim de saúde" ${ }^{125}$. Mais, poder-se-ia supor que a repressão contra o usuário contribuiria, de alguma forma, para a "prevenção do uso indevido, atenção e reinserção social de usuários". Entretanto, será essa uma suposição validamente suficiente para dar conta do problema abordado pela Lei de Drogas?

Em decorrência dessa confusão aparente de objetivos, bem como da inovação legislativa no tocante às sanções previstas à prática do crime, logo após a entrada em vigor da Lei $n^{\circ} 11.343 / 2006$, surgiram alguns discursos sobre um pretensa descriminalização da conduta de porte para uso pessoal de drogas, dentre os quais se destacou Luiz Flavio Gomez, entendendo o novo tipo previsto na lei de drogas como um "ilícito penal sui generis"126.

Fundamentava sua opinião no fato de que a Lei de Introdução ao Código Penal, em seu artigo $1^{\circ}$, determina:

\footnotetext{
${ }^{124}$ GOMES, Luiz Flávio (Org.). Lei de Drogas Comentada. Lei no 11.343/06. 3 ed. São Paulo: Revista dos Tribunais, 2013. p. 112.

${ }^{125}$ MENDONÇA, Andrey Borges; CARVALHO, Paulo Roberto Galvão (Org.). Lei de Drogas: Lei 11.343, de 23 de agosto de 2006. Comentada artigo por artigo. 3 ed. São Paulo: Método, 2012, p. 22.

${ }^{126}$ GOMES, Luiz Flávio (Org.). Op. Cit. p. 114.
} 
Considera-se crime a infração penal que a lei comina pena de reclusão ou de detenção, quer isoladamente, quer alternativa ou cumulativamente com a pena de multa; contravenção, a infração penal a que a lei comina, isoladamente, pena de prisão simples ou de multa, ou ambas, alternativa ou cumulativamente. ${ }^{127}$

Daí porque, em não havendo previsão de aplicação de pena privativa de liberdade, a conduta prevista no artigo 28 da Lei $n^{\circ} 11.343 / 2006$ teria sido excluída do rol das condutas criminosas, permanecendo, no entanto, como ilícito - pois contrária à ordem jurídica -, de natureza penal - porque permanece inserida nesse campo do direito, sendo a condenação considerada, p. ex., para fins de reincidência - sui generis ${ }^{128}$.

A refutar essa opinião, a maioria da doutrina se posicionou no sentido de não ter havido descriminalização do porte para uso pessoal, mas apenas alteração das sanções impostas à conduta, antes punida com a pena privativa de liberdade e agora apenas com medidas alternativas à prisão. A mudança seria quantitativa, e não qualitativa.

Nesse sentido, Vicente Greco Filho, com ênfase afirma:

A lei NÃO DESCRIMINALIZOU NEM DESPENALIZOU a conduta de trazer consigo ou adquirir para uso pessoal, nem a transformou em contravenção. Houve alterações, abrandamento, como adiante se comentará, mas a conduta continua incriminada. A denominação do Capítulo é expressa. As penas são próprias e específicas, mas são penas criminais. ${ }^{129}$

Guilherme de Souza Nucci, no mesmo sentido:

[...] o legislador, ao usuário de drogas, possivelmente sem ousar a ponto de descriminalizar ou despenalizar o delito, preferiu estabelecer medidas de caráter puramente educativo ou recuperador, como se observa nos incisos I a III do art. $28 .^{130}$

\footnotetext{
${ }^{127}$ Disponível em: <http://www.planalto.gov.br/ccivil_03/_ato2004-2006/2006/lei/111343.htm>. Acesso em: 05 jan. 2014.

128 GOMES, Luiz Flávio (Org.). Lei de Drogas Comentada. Lei no 11.343/06. 3 ed. São Paulo: Revista dos Tribunais, 2013.

${ }^{129}$ GRECO FILHO, Vicente; RASSI, João Daniel. Lei de Drogas Anotada. Lei no 11.343/06. 3 ed. São Paulo: Saraiva, 2009. p. 44.

${ }^{130}$ NUCCI apud GUIMARÃES, Marcelo Ovídio Lopes (Org.). Nova Lei Antidrogas Comentada - Lei no

11.343/06. São Paulo: Quartier Latin, 2007, p. 116.
} 
Também nesse sentido, Maria Lucia Karam:

Ao contrário do que muitos querem fazer crer, a Lei n. 11 343/06 não traz assim nenhuma mudança significativa nessecampo do consumo. Os 'defensores' da nova lei querem fazer crer que a previsão de penas nãoprivativas de liberdade seria uma descriminalização da posse para uso pessoal, sustentando que somente seriam crimes condutas punidas com reclusão ou detenção (expressões utilizadas no Código Penal como espécies de prisão). Ignoram que a ameaça da pena é que caracteriza a criminalização. E penas, como a própria Constituição Federal explicita, não são apenas as privativas da liberdade, mas também as restritivas da liberdade, a perda de bens, a multa, a prestação social alternativa, as suspensões ou interdições de direitos, entre outras. ${ }^{131}$

\section{Ainda pela não descriminalização, Fernando Capez:}

Entendemos, no entanto, que não houve a descriminalização da conduta. $\mathrm{O}$ fato continua a ter a natureza de crime, na medida em que a própria Lei o inseriu no capítulo relativo aos crimes e às penas (Capítulo III); além do que as sanções só podem ser aplicadas por juiz criminal e não por autoridade administrativa, e mediante o devido processo legal (...). ${ }^{132}$

É incontroverso que redação da lei sofreu influências de movimentos que buscavam a descriminalização da conduta praticada pelo usuário, o que pode ter gerado certa confusão quando de sua entrada em vigor.

Segundo artigo publicado pela Revista Direito da Fundação Getúlio Vargas, a inovação legislativa pode ter gerado opiniões apressadas sobre a descriminalização, pois:

\footnotetext{
- a pena de prisão está excluída como sanção autorizada em relação a certos crimes;

- é muito raro ver um artigo que tipifica crimes prever ao mesmo tempo (no mesmo artigo) outras penas que não a de morte, de castigo corporal, de prisão ou de multa; -as penas que estão previstas nesse artigo (i) não tem usualmente o status jurídico de penas nas leis criminais, (ii) não são penas selecionadas e valorizadas pelas teorias modernas da pena (retribuição, dissuasão, neutralização e o primeiro paradigma da teoria da reabilitação);

- as penas selecionadas não correspondem de forma plena ao conceito depena que sustenta que "uma verdadeira pena" exige da autoridade a intenção visível de querer infligir um sofrimento ou um mal ao infrator;
}

${ }^{131}$ KARAM apud GRILLO, Carolina Christoph; POLICARPO, Frederico; VERISSIMO, Marcos. A "dura" e o "desenrolo": efeitos práticos da nova lei de drogas no Rio de Janeiro. Rev. Sociol. Polit. - online, vol.19, n.40, pp. 135-148, 2011.

${ }^{132}$ CAPEZ, Fernando. A Nova Lei de Tóxicos: Modificações Legais Relativas à Figura do Usuário. Revista Magister de Direito Penal e Processual Penal. São Paulo, ano III, n.14, p.66-72, out-nov/2006. 
- as penas previstas nesse artigo também não correspondem de forma plena àquelas que a doutrina criminal (ou a sociologia) pensa quando sustenta que "o crime se define pela pena. ${ }^{133}$

Falar em descriminalização seria inapropriado, pois significaria entender que o texto legislativo, autorizou a porte de drogas para consumo pessoal, o que não é verdade. Da leitura do texto legal, percebe-se que o tipo penal está inserido no capítulo "dos crimes e das penas", devendo ser entendido, efetivamente, como se referindo a "verdadeiros crimes" e "verdadeiras penas." 134

A discussão, levada até o pleno do STF, foi dirimida no julgamento do Recurso Extraordinário $n^{\circ} 430.105 / R J$, que acatou justamente o posicionamento no sentido de que todas as condutas previstas no artigo 28 continuam sendo crimes, embora apenadas com medidas diferentes da pena corporal privativa de liberdade. ${ }^{135}$

A decisão consignou, em suma, que o artigo $1^{\circ}$ da Lei de Introdução ao Código Penal se limitou a estabelecer critérios diferenciadores entre os crimes e as contravenções penais, mas não configura óbice para que crimes sejam punidos com outras espécies de sanção, diferentes da pena privativa de liberdade, nos termos do que autoriza o artigo $5^{\circ}$, incisos XLVI e XLVII, da Constituição Federal.

Ademais, deve se atentar para o fato de que não obstante o artigo 28 esteja dentro do “Título III - Das Atividades de Prevenção do Uso Indevido, Atenção e Reinserção Social de Usuários e Dependentes de Drogas", o legislador inseriu o tipo penal no "Capítulo III - Dos Crimes e das Penas". Por fim o crime de porte para uso pessoal de drogas é processado pelo rito sumaríssimo previsto na Lei no 9.099/95 e destinado às infrações de menor potencial ofensivo, de natureza, portanto criminal.

\footnotetext{
${ }^{133}$ PIRES, Alvaro P.; CAUCHIE, Jean -François. Um caso de inovação “acidental” em matéria de penas: a lei brasileira de drogas. Revista da Fundação Getúlio Vargas, n.13, 2013,p. 302.

${ }^{134}$ Ibidem, p.303.

135 BRASIL. Supremo Tribunal Federal. Acompanhamento processual. Recurso Extraordinário RE 430.105/RJ. Disponível em:

<http://www.stf.jus.br/portal/processo/verProcessoAndamento.asp?incidente=2228314. Acesso em:

10 jan. 2012.
} 
Aliás, a título de ilustração, o trecho do relatório do Deputado Paulo Pimenta, Relator do Projeto da Lei no 11.343/06 na Câmara dos Deputados, citado pelo Ministro Sepúlveda Pertence, quando do julgamento do recurso citado, deixa clara a opção legislativa, verbis:

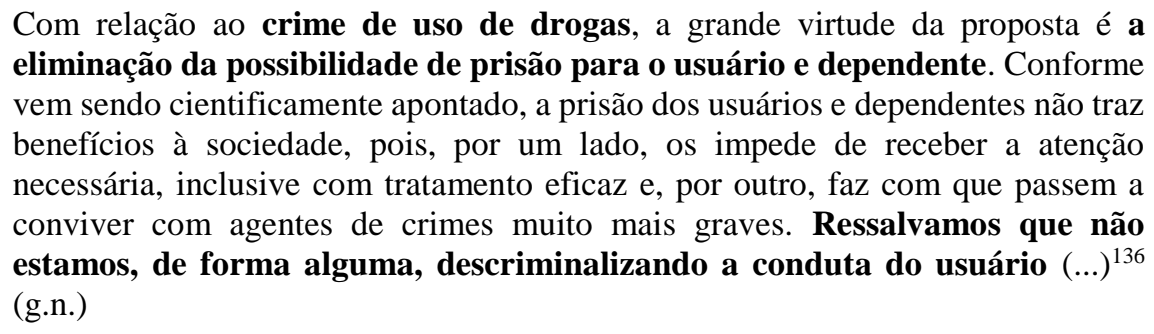

Observe-se, neste ponto, que nem mesmo o descumprimento de uma das medidas previstas no artigo 28, imposta após regular trâmite do processo penal, autoriza a aplicação de pena privativa de liberdade. Para que se induza ao cumprimento da pena aplicada, poderá o juiz se valer, apenas e tão somente, de admoestação verbal ou multa, nos termos do $\S 6^{\circ}$ do artigo 28 da Lei $n^{\circ} 11.343 / 2006$.

Do exposto, se depreende que as alterações trazidas pela nova lei penal foram de ordem quantitativa e não qualitativa, já que a conduta do usuário de drogas permaneceu sendo classificada como crime; e de política criminal, uma vez que a atual legislação rechaça a pena de prisão como resposta adequada ao fenômeno delitivo que descreve. Na prática judiciária, considerando que o procedimento adotado é também o da Lei no 9.099/1995, a situação é muito semelhante àquela vivenciada na vigência da lei anterior. Não é demais dizer, inclusive, que mantido o viés eminentemente punitivo, pouco se alterou a mentalidade dos aplicadores da lei penal, motivo pelo qual a proposta eminentemente integrativa voltada ao usuário de drogas permanece válida apenas no plano teórico, claramente dissociado da realidade.

É muito importante ter claro que embora a Lei de Drogas trace objetivos relacionados à atenção e reinserção social dos usuários a sua conduta foi mantida no rol dos crimes previstos pela legislação pátria.

136 BRASIL. Supremo Tribunal Federal. Recurso Extraordinário RE 430.105/RJ. Íntegra da decisão. Disponível em:

<http://redir.stf.jus.br/paginadorpub/paginador.jsp?docTP=AC\&docID=443566>. Acesso em 07 jan. 2014. 
A menor severidade das sanções impostas, aliada ao discurso de proteção do usuário contido na lei pode conduzir à equivocada ideia de que a previsão de penas alternativas à prisão é suficiente para retirar do indivíduo o rótulo de criminoso, e que as sanções aplicadas aos usuários de droga não são pena, mas outra espécie medida, as vezes chamada até de preventiva, não obstante tenha prevista sua aplicação após o procedimento penal.

Foi esse aliás, o raciocínio explicitado pelo Senado Federal na justificativa final ao Projeto de lei 115 , convertido na Lei $\mathrm{n}^{\circ} 11.343 / 2006$, veiculado pelo parecer 846, da comissão de assuntos sociais:

\begin{abstract}
O maior avanço do Projeto está certamente no seu artigo 28, que trata de acabar com a pena de prisão para o usuário de drogas no Brasil. A pena de prisão para o usuário de drogas é totalmente injustificável, sob todos os aspectos. Em primeiro lugar, porque o usuário não pode ser tratado como um criminoso, já que é, na verdade, dependente de um produto, como há dependentes de álcool, tranquilizantes, cigarro, dentre outros (g.n.) ${ }^{137}$.
\end{abstract}

A conduta prevista no artigo 28 é crime. Os usuários são abordados pela polícia, conduzidos à delegacia, processados perante a justiça criminal. Não carregam o estigma decorrente da privação de liberdade, mas lidam com o peso decorrente do rótulo de criminoso e recebem sanções diferentes da privação de liberdade, mas igualmente repressivas.

A redação legal do artigo que tipifica as condutas relacionadas ao uso de drogas passou a ser a seguinte:

Art. 28. Quem adquirir, guardar, tiver em depósito, transportar ou trouxer consigo, para consumo pessoal, drogas sem autorização ou em desacordo com determinação legal ou regulamentar será submetido às seguintes penas:

I - advertência sobre os efeitos das drogas;

II - prestação de serviços à comunidade;

III - medida educativa de comparecimento a programa ou curso educativo.

\footnotetext{
${ }^{137}$ SENADO FEDERAL. Projeto de Lei no 115/2002. Dispõe sobre o Sistema Antidrogas; sobre a prevenção, a repressão e o tratamento; define crimes, regula o procedimento nos crimes que define e dá outras providências. (VOLUME II). Disponível em: <http://www.senado.gov.br/atividade/materia/detalhes.asp?p_cod_mate=50227>. Acesso em: 07 jan. 2014.
} 
São três, portanto, as sanções possíveis: advertência, a prestação de serviços à comunidade e a medida educativa de comparecimento a programa em curso educativo.

A prestação de serviços à comunidade já inserida no ordenamento jurídico brasileiro como espécie de pena restritiva de direitos mesmo antes da entrada em vigor da Lei $\mathrm{n}^{\circ}$ 11.343/2006, não necessita de maiores considerações.

A pena de advertência, inovação em nosso ordenamento jurídico, teve sua natureza questionada por alguns doutrinadores, havendo afirmações no sentido de que, sem possuir o mínimo caráter retributivo e preventivo, não se se adequa aos requisitos necessários para caracterização como pena e, muito embora a Lei assim permita, não seria possível sua cominação isolada ${ }^{138}$.

A refutar esse posicionamento, Salo de Carvalho, com brilhantismo, leciona:

\begin{abstract}
O ato de admoestação, em razão do caráter de reprovabilidade real ou simbólica, adquire natureza punitiva, adequando-se na proposital lacuna deixada pelo texto constitucional. Com a crise da pena privativa de liberdade e o movimento internacional de reforma dos sistemas punitivos, a Constituição abriu espaço à criação e à proposição de alternativas ao cárcere, fixando os limites possíveis de punibilidade a partir do respeito à dignidade da pessoa humana, e tendo como norteadores da sanção, os princípios da proporcionalidade, da individualização, da pessoalidade e da humanidade. Em não sendo, pois, a admoestação modalidade de privação de liberdade ou multa, nota-se que se aproxima, de forma atípica, das penas restritivas de direitos. ${ }^{139}$
\end{abstract}

Sobre a medida de comparecimento a programa ou curso educativo, entende Salo de Carvalho que o legislador criou uma espécie de sanção híbrida de medida de segurança e medida educativa, que somente seria imposta aos inimputáveis incursos no caput do artigo 28 da Lei $\mathrm{n}^{\mathrm{o}} 11.343 / 2006^{140}$.

\footnotetext{
${ }^{138}$ MENDONÇA, Andrey Borges; CARVALHO, Paulo Roberto Galvão (Org.). Lei de Drogas: Lei 11.343, de 23 de agosto de 2006. Comentada artigo por artigo. 3 ed. São Paulo: Método, 2012. p.28.

${ }^{139}$ CARVALHO, Salo. A Política Criminal de Drogas no Brasil: Estudo criminológico e dogmático da Lei $\mathbf{n}^{0}$ 11.343/06. 6 ed. São Paulo: Saraiva, 2013. p.424.

${ }^{140}$ Ibidem, p. 425 .
} 
Com menos preciosismo, a doutrina entende a última modalidade de sanção prevista no artigo 28, quando fixadas em sentença final, tem natureza de pena. Em outras palavras, "possuem o caráter penal clássico""141.

Sobre o tema, Damásio de Jesus:

\begin{abstract}
A advertência sobre os efeitos da droga, a prestação de serviços à comunidade e a medida educativa de comparecimento a programa ou curso educativo tem a natureza de penas criminais (art. 27 da Lei). Trata-se de penas restritivas de direitos cominadas diretamente em preceito secundário de norma incriminadora. ${ }^{142}$
\end{abstract}

Apesar da absoluta disparidade entre as penas aplicadas ao crime de porte para consumo pessoal e ao crime de tráfico - apenado com reclusão de 5 (cinco) a 15 (quinze) anos e pagamento de 500 (quinhentos) a 1.500 (mil e quinhentos) dias-multa - os critérios para a classificação da ação como um tipo penal ou o outro não são tão claros quanto deveriam.

Nesse ponto, importa ressaltar que a lei de drogas não tipifica o "uso da droga", mas ações a ele relacionadas. "Seria, pois, praticamente impossível utilizar drogas sem incorrer em pelo menos um verbo nuclear do art. $28 \% 143$.

\footnotetext{
A lei não pune e não punia, e não punia, o vício em si mesmo, porque não tipifica a conduta de "usar" (entendimento acolhido por nossos tribunais). Situação semelhante e que resulta num non liquet é do alegado uso no passado, conforme diversas manifestações de nossas cortes. ${ }^{144}$
}

Portanto, a fim de exaurir o rol de condutas possíveis de serem praticadas no que toca ao uso de drogas, o legislador cuidou de praticamente repetir no artigo 28 os verbos nucleares contido no artigo 33, que tipifica o tráfico de drogas. Disso decorre que a diferença entre o crime de porte para uso e o crime de tráfico de drogas é o fim específico do consumo pessoal. Atente-se: o tipo que exige, para sua configuração o elemento específico é o de porte para

\footnotetext{
${ }^{141}$ GOMES, Luiz Flávio (Org.). Lei de Drogas Comentada. Lei no 11.343/06. 3 ed. São Paulo: Revista dos Tribunais, 2013, p.127.

${ }^{142}$ JESUS, Damásio. Lei de Drogas Anotada. Comentário à Lei no 11.343/2006. 9 ed. São Paulo: Saraiva, 2009.

${ }^{143}$ WEIGERT, Mariana de Assis Brasil. Uso de Drogas e Sistema Penal: Entre o proibicionismo e a redução de danos. Rio de Janeiro: Lumen Juris, 2010. p. 73.

${ }^{144}$ GRECO FILHO, Vicente; RASSI, João Daniel. Lei de Drogas Anotada. Lei n ${ }^{\mathbf{0}}$ 11.343/06. 3 ed. São Paulo: Saraiva, 2009.
} 
uso, o crime de tráfico não contém, na redação de seu dispositivo, a exigência da destinação comercial da droga.

Dessa forma, todas as ações empreendida que não tenham como finalidade o consumo pessoal, teriam como consequência sua subsunção ao tipo incriminador do tráfico, solução temerária, haja vista a quantidade de pena imposta ao delito mais grave.

Salo de Carvalho propõe "encontrar forma de clausura do referido tipo, tendo em vista os efeitos patológicos de sua porosidade"145, quais sejam, "os custos produzidos pela excessiva punição de condutas com escassa provocação de danos sociais ou com reprovabilidade menor do que as relacionadas ao comércio ou à produção ilegal de drogas"146.

Objetivando solucionar eventual excesso punitivo decorrente da abertura excessiva do tipo penal, o doutrinador sugere:

\begin{abstract}
Propõe-se, portanto, como critério interpretativo de correção da proporcionalidade no tratamento punitivo de condutas objetivamente idênticas, mas díspares no que tange à ofensividade ao bem jurídico, a necessidade de especificação dos elementos subjetivos de ambos os tipos penais, seja do art. 33 como do art. 28 , da Lei ${ }^{\circ} 11.343 / 06 .{ }^{147}$
\end{abstract}

Se a lei prevê o dolo específico do consumo pessoal no caso do artigo 28 da lei $\mathrm{n}^{\circ}$ 11.343/2006, para que sejam respeitados os princípios constitucionais da proporcionalidade e da ofensividade, imprescindível também que a intenção de comercializar a droga seja comprovada para que haja imputação pelo artigo 33 do mesmo diploma legal.

Por enquanto, o texto legal dispõe apenas:

$\$ 2^{\circ}$ Para determinar se a droga destinava-se a consumo pessoal, o juiz atenderá à natureza e à quantidade da substância apreendida, ao local è̀s condições em que se desenvolveu a ação, às circunstâncias sociais e pessoais, bem como à conduta e aos antecedentes do agente.

\footnotetext{
${ }^{145}$ CARVAlho, Salo. A Política Criminal de Drogas no Brasil: Estudo criminológico e dogmático da Lei no 11.343/06. 6 ed. São Paulo: Saraiva, 2013. p.319.

146 Ibidem,. p. 319.

${ }^{147}$ Ibidem, p.325.
} 
Percebe-se que, muito embora a quantidade da droga seja geralmente o critério ressaltado como divisor de águas no tocante à imputação, ela é um dos muitos elementos que devem ser considerados para a tipificação do delito. Isso significa dizer, portanto, que um indivíduo surpreendido portando pouca quantidade de droga, dividida em pequenas porções, em ponto de tráfico e com grande quantidade de dinheiro em notas baixas, pode ter mais chances de ter sua conduta descrita como a de traficante do que aquele surpreendido portando maior quantidade de droga, em porção única, próximo de sua residência.

Esse primeiro juízo de tipicidade, tendo em vista a diferença dos procedimentos atinentes ao crime de tráfico e ao crime de porte para uso pessoal, será feito ainda na delegacia, na lavratura do termo circunstanciado (no caso de porte para uso pessoal) ou no registro do flagrante (no caso de tráfico), mas ele não é definitivo.

No decorrer do processo, a defesa, o Ministério Público ou o Juízo poderão se manifestar pela desclassificação do delito mais grave para o delito mais leve, caso as circunstâncias demonstrem ter havido excesso na imputação. A consequência prática da tipificação mais gravosa é que, devido à diferença entre as penas aplicadas e, consequentemente do procedimento seguido, o usuário de drogas, tomado por traficante, pode ser submetido, indevidamente, à prisão em flagrante e à prisão cautelar, graças à primeira classificação do delito como tráfico de drogas. Aí, além do peso do estigma usuário criminoso, o indivíduo sofrerá os danos decorrentes da privação de liberdade (e do sofrimento que, no Brasil, é indissociável desse tipo de pena, haja vista a precariedade do nosso sistema carcerário).

Agrava o problema a constatação de que os critérios utilizados para a diferenciação entre a imputação pelo crime de tráfico e uso de drogas estão, na maioria dos casos, ligados aos padrões socioeconômicos do autor. Em outras palavras, dependendo da sua classe social, o indivíduo será usuário ou traficante.

Um estudo realizado pelo Núcleo de Iniciação Científica da Universidade Cândido Mendes, no Rio de Janeiro, realizou uma pesquisa, durante o ano de 2011, com o fim de 
analisar os critérios adotados pelos juízes para determinar se a conduta do autor se subsumia ao crime de tráfico ou ao crime de porte para uso de drogas. ${ }^{148}$

Dentre outros resultados, os pesquisadores concluíram que em $80 \%$ dos casos cuja imputação se deu pelo crime de tráfico, os imputados eram moradores de favelas, sendo certo que em 95\% dos casos os magistrados se baseiam na versão apresentada ela polícia e, em $70 \%$ dos casos em que a defesa pleiteou a desclassificação para o crime de porte para consumo, a tese foi afastada ${ }^{149}$.

Mais alarmante o fato de que, na análise das sentenças, os pesquisadores verificaram que mesmo que a condição socioeconômica do autor seja tão presente quanto a quantidade e forma de armazenamento da droga para ensejar a condenação pelo tráfico, parece que o primeiro fator tem preponderância sobre o segundo, à medida que, num dos casos, um indivíduo preso na posse de $10 \mathrm{~kg}$ de maconha num hotel da zona sul carioca, a acusação por tráfico não foi mantida ${ }^{150}$.

Outra pesquisa que se aproxima mais do âmbito territorial compreendido por este trabalho, foi a realizada pelo Núcleo de Estudos da Violência (NEV) da Universidade de São Paulo sob o título "Prisão Provisória e Lei de Drogas, um estudo sobre os flagrantes de tráfico de drogas na cidade de São Paulo". 151

Para alcançar os resultados pretendidos, a pesquisa se valeu das metodologias quantitativa, representada pela coleta e sistematização dos Autos de prisão em flagrante (coletados entre dezembro de 2010 e janeiro de 2011), e qualitativa, consubstanciada no acompanhamento de audiências, comparação de casos emblemáticos, entrevistas e workshops. A pesquisa foi conduzida nas cidades de Santos, São Paulo e Campinas entre o segundo semestre de 2010 e o primeiro semestre de 2011.

\footnotetext{
${ }^{148}$ CRESPO, Aderlan (Coord.). Critérios judiciais determinantes do consumo e do tráfico. Rio de Janeiro: Universidade Candido Mendes, Núcleo de Iniciação Científica - NIC/UCAM, 2011.

149 Ibidem, p. 6.

150 Ibidem, p. 7.

${ }^{151}$ JESUS, Maria Gorete Marques de. (Org.). Prisão Provisória e Lei de Drogas: estudo sobre os flagrantes de tráfico de drogas na cidade de São Paulo. Núcleo de Estudos da Violência (NEV-USP), 2011. Disponível em: <http://www.nevusp.org/downloads/down254.pdf>. Acesso em: 25 dez. 2013.
} 
Corroborando os resultados encontrados pela pesquisa empreendida no Rio de Janeiro, o NEV constatou que a condição socioeconômica dos indivíduos é considerada, por alguns dos entrevistados, como fator determinante de diferenciação entre o tráfico e o porte para uso de drogas. Um dos delegados entrevistados afirmou:

\begin{abstract}
A diferença é estabelecida de acordo com o poder aquisitivo do apreendido. Se ele tem um poder aquisitivo alto e é pego com 10 papelotes, ele pode ser usuário. Já se uma pessoa de poder aquisitivo baixo é pego com a mesma quantidade é mais fácil acreditar que ele seja traficante, pois ele não tem capacidade financeira de comprar a droga. ${ }^{152}$
\end{abstract}

Entre os resultados encontrados, também podemos destacar que a polícia Militar foi responsável por $85,63 \%$ dos flagrantes, que ocorrem, em sua grande maioria, na via pública (82,28\% dos casos), sendo certo que $62,28 \%$ ocorreram durante o patrulhamento de rotina ${ }^{153}$.

Esses flagrantes, segundo as entrevistas, são motivados pelo que os policiais militares chamam de "atitude suspeita". As definições sobre no que consistiria essa atitude varia entre as entrevistas dadas pelos policiais e seria uma habilidade prática adquirida com o trabalho das ruas. O subjetivismo, portanto, começa aí. Os sujeitos do nosso sistema penal de drogas são escolhidos pelos policiais militares durante o patrulhamento habitual, sem qualquer investigação precedente e segundo os critérios que esses policiais entendem suficientes para determinar a abordagem. Vera Batista ${ }^{154}$, citada por Mariana Weigert, alerta justamente para

\footnotetext{
152 JESUS, Maria Gorete Marques. (Org.). Prisão Provisória e Lei de Drogas: estudo sobre os flagrantes de tráfico de drogas na cidade de São Paulo. Núcleo de Estudos da Violência (NEV-USP), 2011. p.114. Disponível em: <http://www.nevusp.org/downloads/down254.pdf>. Acesso em: 25 dez 2013.

153 Ibidem, p. 153.

${ }^{154}$ Bacharel em Ciências Políticas e Sociais pela Pontifícia Universidade Católica do Rio de Janeiro (1981); Licenciada em Sociologia com Ênfase em Metodologia pela Universidad Nacional Autónoma de Heredia (Costa Rica, 1980); Mestre em História Social pela Universidade Federal Fluminense (1997); Doutora (2003) e Pós-Doutora (2009) em Saúde Coletiva pelo Instituto de Medicina Social (IMS) da Universidade do Estado do Rio de Janeiro ; Pesquisadora do Grupo Epos - Genealogia, Subjetivações e Violências (IMS/UERJ); Professora-Visitante do Programa de Pós-Graduação em Direito da UERJ; Professora Convidada do Curso de Pós-Graduação em Criminologia e Direito Penal do Instituto Superior do Ministério Público do Estado do Rio de Janeiro; Professora Convidada do Curso de Pós-Graduação em Criminologia do IBCCRIM/SP; ex-membro do Instituto Latino Americano das Nações Unidas Para a Prevenção do Delito (ILANUD); ex-Professora do Programa de Pós-Graduação em Sociologia e Direito da UFF; ex-Professora de Criminologia do Programa de Mestrado em Direito da Universidade Candido Mendes-Centro; Secretária-Geral do Instituto Carioca de Criminologia e Diretora da Revista Discursos Sediciosos - Crime, Direito e Sociedade. Disponível em: <http://buscatextual.cnpq.br/buscatextual/visualizacv.do?metodo=apresentar\&id=K4703151E4>. Acesso em: 25 dez. 2013.
} 
o fato de que "a seletividade do sistema e a diferenciação se revelam desde a detenção por 'atitude suspeita'"155.

Não obstante a natureza do tráfico seja justamente o comércio, daí porque muito embora nem todos os verbos nucleares demandem a participação de outras pessoas na prática do crime, o natural seria que, em casos de flagrante, fosse relativamente comum indivíduos surpreendidos acompanhados no momento do comércio, o fato é que, em 69,12\% dos casos, os "traficantes" foram presos sozinhos e, em $48 \%$ dos casos a droga não foi apreendida junto do acusado ${ }^{156}$.

Sobre a prisão de indivíduos que não carregavam consigo a substância, a versão mais comum é a de que o autor do crime, ao visualizara polícia, desfaz-se da droga, a fim de evitar a prisão. A versão é verossímil e, justamente por isso, utilizada com habilidade pelos policiais, que, da mesma forma que desenvolvem, na prática do dia a dia a habilidade para reconhecer a atitude suspeita, parecem também desenvolver a habilidade de justificar suas ações em discursos aceitáveis. Numa das entrevistas realizadas pelos pesquisadores, o Policial Militar afirmou:

\begin{abstract}
É muito comum os policiais falarem na delegacia que viram o acusado jogando o pacote de drogas no chão na medida em que ele corria, mesmo quando isso não acontece. Fazemos isso porque esta é uma forma de conciliar e certificar de que a sacola pertencia à pessoa apreendida. $\mathrm{O}$ advogado tem as estratégias dele, a gente tem que ter a nossa. $\mathrm{O}$ advogado sempre vai falar que não temos como provar que a droga era do menino, mas os PMs geralmente fazem uma pequena campana e sabem que o menino (apreendido) buscava drogas em uma sacola próxima ao local onde permanecia parado. E um indivíduo parado num determinado local conhecido como ponto de venda de drogas é sempre suspeito. ${ }^{157}$
\end{abstract}

A despeito da preocupação do Policial Militar com a alegação dos defensores sobre a ausência de provas nos autos, $74 \%$ dos casos contam apenas com a versão dos policiais que apresentaram a ocorrência, não estando presente nenhuma outra testemunha civil ${ }^{158}$. Como dito acima, numa ação que tem como fim o comércio, seria natural que num número

\footnotetext{
${ }^{155}$ BATISTA, Vera apud WEIGERT, Mariana de Assis Brasil. Uso de Drogas e Sistema Penal: Entre o proibicionismo e a redução de danos. Rio de Janeiro: Lumen Juris, 2010, p.102.

156 JESUS, Maria Gorete Marques. (Org.). Prisão Provisória e Lei de Drogas: estudo sobre os flagrantes de tráfico de drogas na cidade de São Paulo. Núcleo de Estudos da Violência (NEV-USP), 2011, p. 40. Disponível em: 〈http://www.nevusp.org/downloads/down254.pdf>. Acesso em: 25 dez. 2013.

${ }^{157}$ Ibidem, p. 55.

${ }^{158}$ Ibidem, p. 55.
} 
maior de casos pudesse testemunhar, ao menos, o consumidor. No final das contas "são os policiais que decidem quem irá ou não ser processado por mero uso ou tráfico, porque eles são os únicos que apresentam as provas e montam o processo" ${ }^{159}$.

Também conta para a condenação a afirmação do policial sobre a confissão informal realizada pelo preso no momento do flagrante. Em 43,89\% dos casos, os policiais afirmaram ter havido confissão do acusado ${ }^{160}$.

Outro ponto relatado pela pesquisa do Núcleo de Estudos da Violência foi o fato de que, segundo os Policiais Militares, muitos dos indivíduos relatam terem sido vítimas deflagrante forjado. Segundo os policiais, não haveria possibilidade de o policial andar por aí portando diversos tipos de drogas apenas para imputar a alguém, falsamente, a prática de um delito ${ }^{161}$.

Adentrando mais especificamente à diferenciação entre as condutas de tráfico e uso de drogas para consumo pessoal, os pesquisadores questionaram os delegados entrevistados sobre a dúvida no momento da classificação da conduta. Alguns disseram que, em caso de dúvida, liberavam o acusado e instauravam o competente inquérito policial para apurar o caso, outros, no entanto, relatam que mantém de qualquer forma o suspeito preso, baseados no princípio do in dubio pro societate:

Às vezes a gente tem dúvida. Os critérios [para a diferenciação] estão dispostos na
lei: local de abordagem, quantidade de entorpecentes, se há dinheiro apreendido,
antecedentes, testemunha dos policiais, eventual confissão do acusado, uma série
de fatores. Não que ele seja culpado, pois só quem vai poder falar isso é o juiz.
Mas a doutrina defende que na dúvida "in dubio pro societate”, em dúvida,
mantenha o acusado preso. O "in dubio pro reo" é na fase de julgamento. ${ }^{162}$

A consequência prática da diferenciação ocorrida na delegacia é o procedimento processual decorrente da imputação. A Lei no 11.343/2006 impõe, positivamente, sanções muito díspares entre o traficante - apenado com pena privativa de liberdade que varia de

\footnotetext{
159 ZALUAR, Alba apud WEIGERT, Mariana de Assis Brasil. Uso de Drogas e Sistema Penal: Entre o proibicionismo e a redução de danos. Rio de Janeiro: Lumen Juris, 2010.

${ }^{160}$ JESUS, Maria Gorete Marques. (Org.). Prisão Provisória e Lei de Drogas: estudo sobre os flagrantes de tráfico de drogas na cidade de São Paulo. Núcleo de Estudos da Violência (NEV-USP), 2011, p.57.

Disponível em: <http://www.nevusp.org/downloads/down254.pdf>. Acesso em: 25 dez. 2013.

${ }^{161}$ Ibidem, p. 57.

162 Ibidem, p. 58.
} 
cinco e quinze anos - e o usuário - apenado com sanções alternativas à privação de liberdade. Uma das infrações se insere no rol dos crimes equiparados aos hediondos, enquanto outra é considerada infração de menor potencial ofensivo. Como já se mencionou acima caso o usuário seja classificado como traficante, tem grandes chances de responder ao processo preso, vez que foi isso o que ocorreu em $88,64 \%$ dos $\operatorname{casos}^{163}$.

Alia-se a isso o fato de que, como constatou a pesquisa empreendida pela Universidade Candido Mendes, em 70\% dos casos em que a tese da desclassificação do crime de porte para uso pessoal é apresentada, ela é rechaçada pelo juízo ${ }^{164}$. Segundo o Núcleo de Estudos da Violência, dentre os flagrantes analisados que resultaram em processos já finalizados quando do término da pesquisa, 91\% resultaram em sentenças condenatórias, apenas $6 \%$ em desclassificação para crimes mais leves e $3 \%$ em absolvição ${ }^{165}$.

Especificamente nos crimes em que o indivíduo permaneceu preso durante o processo, o NEV constatou ter havido desclassificação para o crime de porte para uso pessoal em $7 \%$ dos casos. Espantosamente, um promotor de justiça entrevistado afirmou o seguinte:

[Ao final] Eu posso pedir a desclassificação por crime de uso, ou então pedir a absolvição do caso. Além disso, denunciar por porte para uso causa um transtorno processual bem maior e mais custoso - consome mais recursos humanos, precisa de mais tempo. Com ele preso pelo menos temos a certeza de que ele vai participar das audiências, não vai fugir e no final eu posso pedir a desclassificação. ${ }^{166}$

O que se vê, portanto, é que muito embora a prisão tenha sido expressamente rechaçada pelo texto legal para sancionar a conduta de porte de drogas para consumo pessoal e a infração correspondente tenha sido inserida no rol das infrações de menor potencial ofensivo, processadas pelo rito sumaríssimo previsto na Lei $n^{\circ}$ 9.099/1995, que tem como princípios norteadores a "oralidade, informalidade, economia processual e celeridade" (art. 62), o fato é que alguns operadores do direito, sob a absurda justificativa de diminuir custos, ainda se utilizam da pena privativa de liberdade contra os usuários, num efetiva e inadmissível burla ao sistema.

\footnotetext{
${ }^{163}$ JESUS, Maria Gorete Marques. (Org.). Prisão Provisória e Lei de Drogas: estudo sobre os flagrantes de tráfico de drogas na cidade de São Paulo. Núcleo de Estudos da Violência (NEV-USP), 2011, p.88. Disponível em: <http://www.nevusp.org/downloads/down254.pdf>. Acesso em: 25 dez. 2013. ${ }^{164}$ CRESPO, Aderlan (Coord.). Critérios judiciais determinantes do consumo e do tráfico. Rio de Janeiro: Universidade Candido Mendes, Núcleo de Iniciação Científica - NIC/UCAM, 2011.

165 JESUS, Maria Gorete Marques. (Org.).Op. Cit., p.78/79.

166 Ibidem, p. 117.
} 
Esse, talvez, seja o preço da discricionariedade propiciada pela abstenção do texto normativo em indicar elementos mais concretos que propiciem a diferenciação entre o tráfico e o uso de drogas, permanecermos encarcerando os mesmos "jovens, de baixa escolaridade, com empregos precários e informais"167, os dispensáveis da nossa sociedade.

${ }^{167}$ JESUS, Maria Gorete Marques. (Org.). Prisão Provisória e Lei de Drogas: estudo sobre os flagrantes de tráfico de drogas na cidade de São Paulo. Núcleo de Estudos da Violência (NEV-USP), 2011, p. 117. Disponível em: 〈http://www.nevusp.org/downloads/down254.pdf〉. Acesso em: 25 dez. 2013. 


\section{O ESTIGMA DO USUÁRIO}

"Quando quis tirar a máscara, estava pregada à cara." Fernando Pessoa, no Livro do Desassossego.

O labeling approach (ou labeling theory, em português, a teoria da rotulação ou etiquetamento) surge nos Estados Unidos da década de 1960 fomentado pelos movimentos de crítica aos valores postos como consensuais na sociedade do pós-guerra. É uma teoria sociológica, interativa simbólica que pode ser aplicada à teoria criminológica inserida no campo das teorias do conflito e que abandona o paradigma etiológico -determinista e o modelo estático e monolítico de análise da sociedade por uma perspectiva dinâmica e contínua. ${ }^{168}$

No início dos anos da década de 1960, os americanos ainda viviam o período pós guerra de expansão econômica e experimentavam, no âmbito internacional, a divisão do mundo em dois polos graças à Guerra Fria. Dessa forma, a sensação de estabilidade aliada à garantia de acesso aos bens de consumo e à união interna contra a ameaçada do inimigo interno provocou uma integração social que marcava a "ideologia do consenso"169 ou, um outras palavras, uma "ideologia do fim da ideologia". ${ }^{170}$ Não se questionava o valor das regras do jogo, o que estava posto era fruto do consenso.

A criminologia clássica se ocupava das questões atinentes à violação dessas regras perguntando o que levava um indivíduo a agir daquela forma, violando as normas comumente aceitas e não se comportando como as pessoas "normais"171. Se as normas estavam postas e lhes era dado viver segundo elas, porque não se adequavam à sociedade em que haviam sido socializados?

Alguns dos estudiosos concederam maior destaque à psique das pessoas argumentando que as violações à norma seriam consequências de falhas de caráter e outros,

\footnotetext{
${ }^{168}$ SHECAIRA, Sérgio Salomão. Criminologia. 2 ed. São Paulo: Revista dos Tribunais, 2008, p.268.

${ }^{169}$ Ibidem, p.271.

${ }^{170}$ DIAS, Jorge de Figueiredo; ANDRADE, Manuel da Costa. Criminologia: o homem delinquente e a sociedade criminógena. 2. reimp. Coimbra: Coimbra Editora, 1997. p.44.

${ }^{171}$ BECKER, Howard. Outsiders: estudos de sociologia do desvio. Rio de Janeiro: Jorge Zahar, 2008. p.10.
} 
mais imbuídos da vertente sociológica que se manteve, alegavam que a sociedade distribuía entre seus membros as mesmas promessas de sucesso, mas meios absolutamente distintos e desiguais para a obtenção desses prêmios. As dificuldades impostas pela estrutura social desigual incitava os jovens a buscarem métodos alternativos de sucesso e mobilidade social o que podia, por vezes, incluir a prática de crimes.

Em contraposição ao mencionado consenso, começa a surgir, nos Estados Unidos um forte movimento de contracultura disposto a questionar todos os valores sociais, numa óbvia recusa ao monismo cultural. O estudo das normas passa a ser visto num contexto de pluralidade de valores e até mesmo de conflito, como expressão do domínio de certo grupo ou classe de pessoas sobre o restante da sociedade ${ }^{172}$, transformando pessoas comuns em criminosos.

Não era possível não questionar um estado que se mostrava mais complacente com os crimes de colarinho branco do que com as comportamentos ligados ao processo político ou ao uso de drogas ${ }^{173}$ e o estudo do crime passa ser visto sob a perspectiva de o que seriam crimes e quem seriam os criminosos, bem como sob qual o papel da justiça criminal nesse contexto de conflito?

É, portanto, a partir do labelling que a pergunta feita pelos criminólogos passa a mudar. Não mais se indaga o porquê de o criminoso cometer crimes. A pergunta passa a ser: por que algumas pessoas são tratadas como criminosas, quais as consequências desse tratamento e qual a fonte de sua legitimidade? ${ }^{174}$

A teoria, que se fortaleceu nos anos sessenta, buscou inspiração em estudos sociológicos anteriores que já alertavam para o fato de que o sistema de justiça criminal poderia, ao contrário do esperado, aprofundar as raízes do problema. Shecaira lembra que Lombroso era taxativo em afirmar que as condições do sistema prisional poderiam influenciar negativamente os desviantes institucionalizados e Shaw, na sua obra Jack-Roller, realizou uma brilhante análise sobre indivíduos que, tendo cometidos pequenas infrações quando jovens, embrenham-se na carreira criminosa após terem sido enviados para instituições correcionais para crianças e adolescentes ${ }^{175}$.

\footnotetext{
172 DIAS, Jorge de Figueiredo; ANDRADE, Manuel da Costa. Criminologia: o homem delinquente e a sociedade criminógena. 2. reimp. Coimbra: Coimbra Editora, 1997. p.43

173 Ibidem, p.47.

${ }^{174}$ SHECAIRA, Sérgio Salomão. Criminologia. 2 ed. São Paulo: Revista dos Tribunais, 2008. p.291.

${ }^{175}$ Ibidem. p.285/286.
} 
Hebert Blumer, em 1937, usa pela primeira vez a expressão "interação simbólica" para descrever o processo de condicionamento recíproco a que são submetidos os indivíduos nas suas relações sociais ${ }^{176}$ e Frank Tannembaun, em 1938, coloca em evidência o processo de estigmatização do indivíduo - dramatization of evil (dramatização do mal) - no quadro geral de preocupações atinentes à justiça criminal, uma vez que a pessoa se desenvolveria de acordo com o rótulo que lhe fosse atribuído. ${ }^{177}$

O labeling, também chamado de teoria da rotulação social, ou do etiquetamento, parte do pressuposto de que o desvio não se aperfeiçoa por uma qualidade do ato em si, mas pela reação social a ele atribuída. Em outras palavras "grupos sociais criam o desvio ao fazer as regras cuja infração constitui desvio" 178 e o desviante não é, senão, alguém a quem esse rótulo de desviante foi aplicado com sucesso ${ }^{179}$.

\footnotetext{
Bajo um punto de vista sociológico, la desviación puede definirse como uma actividad que, sgún la opinión general, requiere la atención de agentes de control social; es decir, uma conducta que exige que "se haga algo". La desviación no és algo inherente a algunas formas de comportamento, sino algo atribuído a las mismas por el público que directa o indirectamente las contempla ${ }^{180}$.
}

Partindo da ideia de que o de o desvio é uma qualidade do ato atribuída pela reação social a ele correspondente, a análise do criminoso se desloca dos atores da ação, para os atores da reação social, uma vez que a identidade não é um dado sobre o qual atuam forças internas e externas, mas sim um processo de construção e interação contínuos. Os delinquentes só podem ser tratados como um grupo homogêneo parindo-se do prisma da reação negativa dos "normais" ao ato por eles praticado, porque a única característica comum entre eles é a submissão as respostas das agências oficiais de controle.

Como o desvio é, entre outras coisas, uma consequência das reações dos outros ao ato de uma pessoa, os estudiosos do desvio não podem supor que estão lidando com uma categoria homogênea quando estudam pessoas rotuladas de desviantes. Isto é, não podem supor que essas pessoas cometeram realmente um ato desviante

\footnotetext{
176 SHECAIRA, Sérgio Salomão. Criminologia. 2 ed. São Paulo: Revista dos Tribunais, 2008, p.286.

177 DIAS, Jorge de Figueiredo; ANDRADE, Manuel da Costa. Criminologia: o homem delinquente e a sociedade criminógena. 2. reimp. Coimbra: Coimbra Editora, 1997. p.51.

${ }^{178}$ BECKER, Howard. Outsiders: estudos de sociologia do desvio. Rio de Janeiro: Jorge Zahar, 2008. p. $21 / 22$.

179 Ibidem, p. 21/22.

${ }^{180}$ DEL OLMO, Rosa (Comp.). Estigmatizacion y conducta desviada. Maracaibo: Universidad del Zulia, 1973. p.41.
} 
ou infringiram alguma regra porque o nosso processo de rotulação pode não ser infalível; algumas pessoas podem ser rotuladas de desviantes sem ter de fato infringido uma regra, Além disso, não podem supor que a categoria daqueles rotulados conterá todos os que realmente infringiram uma regra, porque muitos infratores podem escapar à detecção e assim deixar de ser incluídos na população de "desviantes" que estudam. À medida que a categoria carece de homogeneidade e deixa de incluir todos os casos que lhe pertencem, não é sensato esperar encontrar fatores comuns de personalidade ou situação de vida que expliquem o suposto desvio. O que é, então, que pessoas rotuladas de desviantes tem em comum? No mínimo, elas partilham o rótulo e a experiência de serem rotuladas como desviantes. ${ }^{181}$

Essa ideia permite ao labeling contestar os postulados epistemológicos da criminologia tradicional e retirar, de uma vez por todas a ideia da dimensão ontológica da delinquência ${ }^{182}$.

\begin{abstract}
Algunos indivíduos que beben demasiado reciben el nombre de alcohólicos, y otros no; ciertos que actuan de manera estraña son cerrados em el manicômio y otros no; sólo algunos indivíduos sin médios de vida conocidos tienen que comparecer ante el tribunal por vagos... y la diferencia entre unos y otros depende casi exclusivamente de la manera com que la comunidade interpreta los numerosos datos personales que someta a clasificación. A este respecto el tamiz de la comunidade puede ser objeto de um estúdio más interessante para la investigación sociológica, que la conduta real del individuo ${ }^{183}$.
\end{abstract}

A consequência da rotulação desse agente como desviante será a doção de atitudes desagradáveis e pouco cordiais dos normais em relação a esse indivíduo inserindo-o num processo de despojamento de sua identidade para adoção do estigma que se sobreporá as suas diversas características como qualidade essencial da sua personalidade. É dizer:

Uma das fases desse processo de socialização é aquela na qual a pessoa estigmatizada aprende e incorpora o ponto de vista dos normais, adquirindo, portanto, as crenças da sociedade mais ampla em relação à identidade e uma ideia geral do que significa possuir um estigma particular. Uma outra fase é aquela na qual ela aprende que possui um estigma particular e, dessa vez detalhadamente, as consequências de possui-lo. ${ }^{184}$

Em outras palavras, a resposta à situação de desvio desencadeia uma potencial distância social entre os outros e o indivíduo desviante, reduzindo a sua margem de oportunidades legítimas e, em relação ao âmbito restrito do indivíduo estigmatizado, provoca

${ }^{181}$ BECKER, Howard. Outsiders: estudos de sociologia do desvio. Rio de Janeiro: Jorge Zahar, 2008. p. 22. 182 DIAS, Jorge de Figueiredo; ANDRADE, Manuel da Costa. Criminologia: o homem delinquente e a sociedade criminógena. 2. reimp. Coimbra: Coimbra Editora, 1997. p.346.

${ }^{183}$ DEL OLMO, Rosa (Comp.). Estigmatizacion y conducta desviada. Maracaibo: Universidad del Zulia, 1973. p.42.

${ }^{184}$ GOFFMAN, Erving. Estigma: notas sobre a manipulação da identidade deteriorada. $4^{\mathrm{a}}$ ed. Rio de Janeiro: LTC, 1988. p.30. 
a conformação às expectativas estereotipadas da sociedade a autorrepresentação como delinquente $^{185}$ num mergulho interativo chamado pelos teóricos do labeling de role engulfment ${ }^{186}$. "De maneira bastante cruel, pode ser dito que, à medida que o mergulho no papel cresce, há uma tendência para que o autor do delito defina-se como os outros o definem."187

Essa multiplicação das situações de desvio, desencadeada pela assunção do rótulo atribuído é o que os teóricos chamam de desviação secundária. Nas palavras de Edwin M. Lemert:

\begin{abstract}
Hay un aspecto en el proceso de la desviación cuyo reconocimiento se nos impone por el hecho de que, a consecuencia de la desviación persistente o de la diferenciación denigrante, algo sucede "debajo de la piel" de la persona desviada. Algo se forma dentro de la psiquis o del sistema nervioso como resultado de las penalidades sociales o "ceremonias degradantes", o de resultas de haber sido objeto de "tratamento" o "rehabilitación". La percepción de valores y médios de parte del individuo y la estimacion de sus costos se someten a uma revisión de tal manera que símbolos que sirven para limitar las elecciones de la mayoriade las personas provocan poca o ninguna respuesta em él o bien engendran respuestas contrarias a las buscadas por otros. ${ }^{188}$
\end{abstract}

Embora a criminologia refira-se, no mais das vezes, ao papel estigmatizante que tem o rótulo de criminoso, o fato é que todo o desvio, toda ação que não corresponda à realidade esperada dos normais, faz com que o indivíduo seja colocado à margem da sociedade e a ele sejam relegados apenas os parcos caminhos que são dados à pessoas taxadas pela inferioridade.

Qualquer etiqueta negativa é prejudicial a um desenvolvimento saudável porque "crean uma identidade desviada altamente visible, danãndo la autoimagem y las expectativas sociales que pueden tender a perpetuar e intensificar el comportamento mismo que se objeta." 189

\footnotetext{
${ }^{185}$ DIAS, Jorge de Figueiredo; ANDRADE, Manuel da Costa. Criminologia: o homem delinquente e a sociedade criminógena. 2. reimp. Coimbra: Coimbra Editora, 1997. p.353

${ }^{186}$ SHECAIRA, Sérgio Salomão. Criminologia. 2 ed. São Paulo: Revista dos Tribunais, 2008. p.294.

${ }^{187}$ Ibidem, p.294.

${ }^{188}$ LEMERT, Edwin M. apud DEL OLMO, Rosa (Comp.). Estigmatizacion y conducta desviada. Maracaibo: Universidad del Zulia, 1973. p.97.

${ }^{189}$ DEL OLMO, Rosa (Comp.). Op. Cit.. p.105.
} 
Os usuários de crack são atingidos pelas rotulações em diversos níveis: primeiro, por serem usuários de drogas, o que, de per si, os relega a uma qualidade de seres humanos inferiores, que não souberam lidar com os problemas comuns da vida sem a ajuda de substâncias estranhas. Em segundo lugar, por serem usuários de uma droga considerada ilícita e, consequentemente, alçados à clandestinidade do consumo e ao contato com o âmbito do ilícito para aquisição da substância. Em terceiro lugar, mesmo dentre os usuários de drogas ilícitas são considerados inferiores, à medida que o crack tem sido classificado com a pior das drogas, seu uso é sinônimo do fundo do poço. Por último, considerando que todas as ações relacionadas ao uso permanecem criminalizadas no ordenamento jurídico pátrio são, eles mesmos, criminosos e sujeitos às cerimônias degradantes vinculadas ao processo penal, da qual falaremos mais adiante.

O preconceito e distanciamento dos normais foi relatado por todos os usuários durante a realização das entrevistas, quando perguntados se sentiam diferentes das outras pessoas. Note-se, a questão não se referia à atitude das outras pessoas em relação a eles, o que também foi relatado, mas ao sentimento individual de diferente, o que sugere a interação com o papel atribuído.

"Tenho vários complexos dentro de mim... Aí eu digo pra mim que sou diminuído como ser humano, né? A sociedade não me aceita. Algumas coisas dentro de mim, os medos, ofamoso medo que não me deixa crescer. E por muitas vezes eu tenho medo de dar certo, né? Aí eu fico parado..."

Entrevistado P1

"Porque isso existe, principalmente em sociedade, um monte de gente. Você usa droga todo o mundo vai te olhar torto. E às vezes a pessoa que te olha torto, é bem pior que você."

\section{Entrevistado P2}

"Olha, eu tive problema de drogas, essas coisas, bebida, eu tenho pânico que foi desencadeado; não estou trabalhando; as pessoas na sociedade não aceitam; apesar de eu ter dinheiro para me sustentar, essas coisas, elas pegam e acham que você é vagabundo, que não sei o quê. Quando você bebe, “ah, tá vendo? É 
porque ele bebe, que aconteceu isso". Uma vez eu levei um tombo na rua, e não estava bêbado. Vieram falar que era porque eu estava bêbado. Então isso magoa muito [...] O cara pegou HIV, porque ele é um merda, usou droga pra caralho e se fudeu”, entendeu? Então é mais ou menos. Minha família sabe que eu tenho. Então... Você fica meio que marginalizado. A sociedade te marginaliza. Ela não entende que é uma doença."

\section{Entrevistado P3}

“Ah, eles não gostam, né, de estar junto; não sei, ele tem medo de ser roubado. Uma coisa assim, eu acho. [perguntado se o medo das pessoas era exagerado] Não. Eu acho que é exagerado, mas eu comigo, eu vejo assim, eu também me sinto assim meio desconfiado que a pessoa venha fazer alguma coisa e... De deixar essa pessoa entrar dentro de casa e me roubar alguma coisa. Porque eu já passei por isso e a pessoa faz, não é? Eu me sentia diferente, eu não me sentia diferente não. Às vezes eu me sentia, não é? Eu me sentia..., que eu podia fazer isso; eu usava drogas e ele não, a outra pessoa não. É isso.”

\section{Entrevistado P6}

“Ah, a gente sente. Se sente um lixo, assim [...]Porque a gente fica um lixo. A gente fica sem tomar banho. As pessoas discriminam você, de ficar perto de você. Se a gente tá sentada em um lugar, as pessoas falam: "Ah, aquele bando de drogados". "

\section{Entrevistado P7}

“[...] quem usa crack é discriminado entre os usuários. Entre os traficantes. Não são pessoas de confiança. Até na própria favela, às vezes... Vai pegar o crack e a pessoa fala: "pô, por que você está usando crack? Você usava cocaína e agora vai ficar usando pedra? Isso é coisa para nóia”. Então, é bem frisado esse aspecto de usuário de crack como uma pessoa que... Como é que eu vou te dizer? [...] É a ralé. 
[parentes] Entendem como vagabundagem, com sem-vergonhice. Não é assim. A pessoa tem é... Eu acredito eu que tenho uma predisposição ao vício e é uma coisa muito forte. É uma necessidade que você tem de usar, né?"

\section{Entrevistado P8}

"Quando você está usando crack? Droga? As pessoas olham como se fosse: "Olha lá. Sem futuro. Vai morrer. É nóia”. Porque é isso que acontece."

Entrevistado P11

Três dos entrevistados, mesmo após afirmarem ter se sentido diferente dos "normais" por serem usuários de drogas, quando questionados sobre o acerto do rótulo a eles conferido, responderam que a decisão dos outros era acertada, demonstrando um nível de introjeção do estigma tão elevado que, diante dos iguais, seriam reprodutores do mesmo comportamento. ${ }^{190}$

“[perguntado se o medo das pessoas era exagerado] Não. Eu acho que é exagerado, mas eu comigo, eu vejo assim, eu também me sinto assim meio desconfiado que a pessoa venha fazer alguma coisa e... De deixar essa pessoa entrar dentro de casa e me roubar alguma coisa. Porque eu já passei por isso e a pessoa faz, não é? Eu me sentia diferente, eu não me sentia diferente não. Às vezes eu me sentia, não é? Eu me sentia..., que eu podia fazer isso; eu usava drogas e ele não, a outra pessoa não. É isso."

\section{Entrevistado P6}

"[você acha que as pessoas tem razão?] Com certeza. Eu acho. Porque dá..., hoje em dia você..., hoje, aqui hoje, eu não tô usando mais, quando eu vejo uma pessoa assim, eu fico com dó. Mas outra pessoa que não usa, não entende o lado daquela pessoa. Que ela precisa de uma ajuda e precisa entender que ela precisa de ajuda. Que o mais difícil é você saber que você precisa de ajuda,

${ }^{190}$ GOFFMAN, Erving. Estigma: notas sobre a manipulação da identidade deteriorada. $4^{\text {a }}$ ed. Rio de Janeiro: LTC, 1988, passim. 
porque é tão chato você precisar de ajuda. É mais fácil você ajudar do que você precisar de ajuda."

\section{Entrevistado P7}

"Por exemplo, a gente mexe com artesanato, os hippies não se mistura com quem é favozeiro, aquele que só bebe e pede dinheiro para usar a droga dele e a cachaça. Isso para a gente é favozeiro. A gente não. A gente usa droga, mas estamos fazendo ali a nossa arte, estamos vendendo coisas que a gente mesmo faz. Então, se um cara desse cola do nosso lado, ninguém vai vir no nosso pano. Ninguém vai vir. Vai falar: "É igual”. Entendeu? Ninguém vai vir. Que nem na Cracolândia, eu vou lá, às vezes eu passava lá, pegava droga e ia embora. Fumava na São João. Porque se você ficar lá, você é igual. É complicado. As pessoas olham você... Se vocêficar junto, eles olham você: "Pronto. É um nóia". Eu mesma já tive esse pensamento quando parei de usar um tempo, quando eu fiquei um tempo suava, eu passava falava: "Nossa, eu estava assim. Meu Deus eu estava desse jeito. Não acredito”. Você fica um zumbi. Entendeu? Mas você não pode fumar a primeira. Se você fumar a primeira, aí você ... Todo mundo é amigo, é tudo igual, porque você está naquela brisa daquela paranóia da droga. Você não está nem vendo. Você se esquece que está todo mundo te vendo, entendeu? Você esquece do mundo. Você só quer aquilo."

\section{Entrevistado P11}

Por outro lado, a estigmatização nos diversos níveis mencionados ficou particularmente clara nas entrevistas conduzidas com os profissionais de saúde, que foram questionados.

Sobre o preconceito entre os "normais" e os usuários de drogas, os profissionais descrevem tanto a marginalização dos usuários, quanto o sentimento de auto depreciação, demonstrando que o rótulo, em muitos casos, já se encontra arraigado como traço de personalidade:

"O estigma é muito grande ainda nos dias de hoje. Como sendo usuários de drogas, como sendo violentos, então, eles vão sendo associados a vários 
estigmas, não é? então, é violento, a pessoa é vagabundo. Enfim, todos esses adjetivos horríveis eles são..."

\section{Entrevistado E1}

"Eles se acham sempre menos do que a maioria das pessoas. São pessoas com uma autoestima muito rebaixada, se acham marginais, se acham pouco dignos da maioria dos privilégios que se possa ter na vida, são pessoas que sempre se acham menos do que qualquer outra pessoa. "

Entrevistado E4

"Acho que eles se sentem excluídos. Porque eu lembro, assim, no CAPS AD que eu trabalhava com uma população mais de classe média baixa, classe baixa, muitos deles tinham vergonha de estar no grupo, de participar do grupo, de se expor. E daí eles falavam muito da coisa do preconceito no trabalho, que eles tinham que, muitas vezes, não tinham uma abertura, sei lá, com a assistente social, com a psicóloga da empresa para falar muito sobre a questão, que a empresa não via isso com bons olhos. Embora, hoje existam empresas que ofereçam programas de recuperação, investem até no funcionário, mas ainda tem muito preconceito. Preconceito não só no mercado de trabalho, mas, assim, de uma forma geral, pela população em geral. Nem todos vêem... Eu tenho alunos, eu sou professora, dou aula para o Curso de Serviço Social, e eu vejo os alunos na graduação, embora eu trabalhe essa questão da saúde mental, essa questão da dependência química com eles, que é uma das áreas de atuação do assistente social, mas eu vejo muita resistência. Eu vejo muita resistência. Ah não. Vai muita para a coisa moral. Muito assim: "Não, o cara é vagabundo mesmo. Ele não está afim. Ele não quer se tratar. Ele quer ficar nessa vida aí usando". Eu estou falando mesmo linguagem popular. Ele quer ficar usando mesmo. Não quer ter compromisso com a família. Não quer ter compromisso com o trabalho. É isso aí. Não assume nada. E, às vezes, não é isso. É falta de oportunidade. É falta de oferecer. É falta de acolher. De incluir em programas sociais, de pensar na efetivação dos direitos dessa pessoa, enquanto cidadão. Que ele tem seus direitos básicos. Precisa ser preservado. Direito à saúde, direito à boas condições de moradia, direitos básicos que são previstos na 
Constituição Federal. Então, eu tento trabalhar nessa questão da efetivação dos direitos que esse cidadão, independente da condição dele de usuário precisa ter."

\section{Entrevistado E5}

"Se sentem muito diminuídos. Isso me parece que é uma coisa que dói muito. E eles não se dão conta que isso é trocado. Eles também, por conta do uso das substâncias, eles também abandonam as outras pessoas. Não é que as pessoas abandonam por isso. Mas eles também vão se isolando cada vez mais por conta do uso, em busca da substância. Então, eles não se dão conta que eles também. Eu costumo dizer que às vezes, acho que eles abandonam primeiro e depois que eles começam a sentir a falta do outro, de fato. Quando eles estão sozinhos mesmo. Se sentem mais sozinhos."

\section{Entrevistado E7}

"Eu acho que eles carregam um sofrimento diferenciado, porque eu acho que há um perfil de pessoa que lida com o sofrimento diferente do resto e é uma minoria. Não é uma maioria. Quer dizer, a gente tem um grupo grande de pessoas que usam, mas a maioria das pessoas não viciam. E as pessoas se viciam por motivos completamente singulares também. E acho que essas pessoa que se reconhecem, que sabem que são dependentes sim. Elas sofrem sim. Acho que são estigmatizadas sim e se sentem assim, diferenciadas do resto do grupo. Com certeza. Isso está muito no imaginário social. Inclusive delas."

\section{Entrevistado E11}

"Sim, a maioria sente. Porque eu acho que a nossa sociedade vê isso, em grande parte, como um problema moral. Uma falta de autodeterminação ou de controle, na verdade é uma falta de controle, mas sem essa questão pejorativa porque eu entendo, enquanto médico, que a doença é justamente isso: a perda de controle. Então eu não vejo sob o ponto de vista moralista, o indivíduo que não foi forte o suficiente, que não resistiu. Eu acho que essa é uma visão muito, vamos dizer assim, "religiosa"., 
Sobre o preconceito dos usuários de drogas lícitas em relação aos usuários de drogas ilícitas, os profissionais descrevem uma diferenciação que extrapola os limites dos locais de tratamento. Isso porque muito embora o álcool seja uma droga de efeitos nefastos para o organismo dos indivíduos, seu potencial lesivo parece subvalorizado em virtude da licitude e da difusão do uso. É comum fazer uso de álcool, de modo que seu consumo só será tratado como problema se efetivamente constata a falta de controle.

Ademais, o álcool não é nem sequer incluído no gênero "drogas”, como exemplo máximo temos o CAPS-AD “Centro de Atenção Psicossocial em Álcool e Drogas”. Quando incluído no gênero, parece ocupar uma posição diferenciada. O slogan mais comum é “Álcool e outras drogas":

“[...] já tivemos aqui momentos bem tensos de alcoolistas com usuários de outras drogas. Então, o alcoolista achar que é muito melhor ou ele é muito mais digno do que o colega que está no mesmo grupo, mas porque o outro faz uso de drogas ilegais. Então, ele, enfim, ele não é um drogado. Drogado é aquele que usa cocaína, crack, maconha, etc. E a bebida não. É menos. É menos grave. A pessoa não fica tão dilacerada, o que é um erro, um equívoco enorme."

Entrevistado E4

“[...] as drogas lícitas, teoricamente são aceitáveis pela população. Vocêfumar, você usar um cigarro de nicotina, você beber, tem gente que acha... Quem bebe, nossa. Fica mais sociável, uma pessoa mais alegre. Então, é um meio de socialização nos grupos, de uma maneira geral, até de ser aceito, não é? E a droga ilícita não. Ela já tem toda aquela estigmatização. Por exemplo, você pega um usuário de crack. Você pergunta para qualquer pessoa na rua, o que ele vai pensar: "Deus me livre. Está quase em condição de uma pessoa excluída socialmente, a maior parte fica em situação de rua, fica naquelas casas abandonadas. Vem aquela imagem meio que parece caracterizada como mendigo. Se arrastando pela rua. Então, é muito diferente. É muito diferente. Inclusive, tem um livro que fala dos vencedores viciados, que inclusive eu tenho esse livro antigo já, mas é de um rabino, que ele estudou e tal. E na Comunidade 
Judaica, que tem vários vencedores viciados. E daí ele fala dos grandes executivos, inclusive médicos, grandes profissionais e que fazem uso de substâncias. Ali na pesquisa fala muito do uso do álcool, enfim, mas tem as drogas ilícitas também. Do quanto que essas pessoas são para a sociedade vencedores, que conquistaram grandes coisas. Muitos têm grandes títulos, muita coisa importante, mas, por trás, são pessoas numa condição de viciados, mas que criaram uma máscara para a sociedade, mas por trás, para manter todo aquele padrão, muitos fazem uso de substância."

Entrevistado E5

“[...] pelo exemplo de grupo, os usuários de álcool, eles geralmente falam: “Não. Meu problema é só com álcool. Eu não uso outras drogas". Sabe que o álcool é uma droga, mas por ser lícita, então, assim, a gente sente que o tom da voz é: “Ah, tudo bem. É álcool. É lícito”. Cigarro eles nem comentam. A maioria usa cigarro e nem comenta, como sendo uma droga. Geralmente é de álcool para cima. Então, acho que tem uma escalada. Álcool, maconha, cocaína e crack que é o vim da linha."

Entrevistado E6

"Os usuários de drogas líticas, os alcoolistas, na fala deles muitas vezes vem essa fala de: "Ah, mas eu não sou como eles. Eu uso álcool”. Então, na fala do usuário de álcool vem essa coisa de "eu não sou como eles. Eu sou diferente”. Na fala do usuário de drogas ilícitas, não vem."

Entrevistado E10

“[...] os usuários de álcool, na minha opinião, muitas vezes são preconceituosos com os usuários de outras drogas: "Ah, o outro usa droga”. Eu falo: "Mas você não usa também?"'então, assim, até dentro do grupo dos dependentes há uma diferença entre os alcoolistas e os outros usuários, os usuários que fazem uso de outras substâncias."

Entrevistado E11 
"A gente não consegue derrubar o hábito de falar "álcool e outras drogas". Então as pessoas que... Começa que cigarro não é droga, não é? Isso é universal, as pessoas não consideram o cigarro uma droga, um problema, e aí já começa errado. Aí você vai para o álcool e é "álcool e outras drogas", então o álcool já está em um patamar diferente. E isso mesmo entre os profissionais, nos congressos, no nome dos serviços. Então, o nome do serviço de tratamento é CAPS-AD, CAPS Álcool e Drogas. Não, o álcool está no bolo das drogas. Então a gente não consegue enxergá-las na mesma categoria, embora sejam todas drogas, todas danosas. E os pacientes têm muito essa diferença. Inclusive, os pacientes têm uma gradação entre as drogas, acho que rola essa diferença entre quem usa droga também. Então: "Ah não, eu não uso crack, eu uso só maconha”, ou: "Eu não uso crack, eu uso só cocaína”. Então acho que só quem usa crack é que está ferrado e não tem para onde fugir. Mas sem dúvida tem o preconceito."

\section{Entrevistado E13}

“[o preconceito existe] Muito claramente. O pessoal que é dependente de álcool acha que está muito melhor do que os dependentes de drogas ilícitas e, inclusive, eles olham de uma forma preconceituosa, como se aquilo fosse uma coisa horrível e o deles não, o deles é uma coisa mais aceitável pelo status de legalidade da droga."

Entrevistado E15

O preconceito em relação ao usuário específico de crack parece estar sempre atrelado à ideia de uso compulsivo, marginalidade, ausência de autocuidado geral e violência, estereótipo amplamente divulgado pela mídia:

“As drogas mais pesadas, eu escuto gente falando: “Ah, mas você é só usuário de álcool. Você não sabe o que é ser usuário de crack. É muito pior”. Quer dizer, você desceu muito mais, você está mais decadente do que um usuário de álcool. Não é? Por exemplo, o álcool é uma droga aceita. Muitas vezes eles acham que por serem usuários de crack são piores. São mais decadentes." 
"[Você acha que existe um preconceito em relação, dentro dos usuários de drogas ilícitas em relação aos usuários de crack?] Há sim. É curioso, porque às vezes eles falam assim: "Nossa, aquele cara usa crack e nem parece”. Então, o crack tem uma identidade, uma figura já formada. A pessoa que usa crack vai ser daquele jeito. Quem usa álcool, cigarro vai ser daquele jeito. Eles montam um estereótipo para cada tipo de droga."

Entrevistado E6

“[..] ] usuário de crack é o fundo do poço, é o nóia. E os pacientes que não usam crack fazem muita questão de deixar muito claro que eles não se misturam. Existe muita marginalização mesmo com o dependente de crack."

Entrevistado E13

“[o preconceito] Existe. Eu já vi vários usuários, dependentes de cocaína, acharem que o pessoal que é dependente de crack é o fim da linha, uma conotação muito pejorativa mesmo (...) a mídia faz com que a população associe o crack à situação de vulnerabilidade social, às cracolândias, à situação de indigência, à miséria social mesmo. Então fica muito associado o crack a essa situação, quando a gente sabe que tem pessoas de outro nível também que são dependentes de crack, só atualmente tem 3 médicos aqui que são dependentes de crack, meus pacientes. E são pessoas que têm filhos, têm família, têm emprego. Não que eles estejam bem, eles não estão bem, mas não tem nada a ver com aquela situação da cracolândia. Então eu acho que é por conta de preconceito mesmo."

\section{Entrevistado E15}

A rotulação será tão mais danosa quanto maior for a publicidade dada ao momento da rotulação. Assim, dado o conteúdo pejorativo do rótulo atribuído, o natural é que os desviantes tentem esconder essas características o quanto podem. As tensões, segundo Goffman ao discorrer sobre o Estigma, são de duas ordens diferentes dependendo do conhecimento do público acerca do seu defeito: 
O termo estigma e seus sinônimos ocultam uma dupla perspectiva: assume o estigmatizado que a sua característica distintiva já é conhecida ou imediatamente evidente ou então que ela não é nem conhecida pelos presentes e nem imediatamente perceptível por eles? No primeiro caso, está se lidando com a condição do desacreditado, no segundo, com a do desacreditável. ${ }^{191}$

Numa das entrevistas, o profissional da equipe fixa relatou o receio dos usuários de que seu problema seja divulgado:

"Hoje mesmo, eles estavam falando muito de: "Não quero que ninguém saiba, porque não quero contar para todo mundo que eu agora estou fazendo um tratamento".,

Entrevistado E1

É que, despojado publicamente de sua identidade pelo que se convencionou chamar, após Garfinkel ${ }^{192}$, de cerimônias degradantes, sua individualidade será reconstruída tendo como característica principal o rótulo consequente do ato desviado, pelo que, justifica-se o esforço em manter oculto o estigma já existente, para evitar maiores proporções.

(...) quando a diferença não está imediatamente aparente e não se tem dela um
conhecimento prévio (ou, pelo menos, ela não sabe que os outros a conhecem),
quando, na verdade, ela é uma pessoa desacreditável, e não desacreditada, nesse
momento é que aparece a segunda possibilidade fundamental em sua vida. A
questão que se coloca não é a da manipulação da tensão gerada durante os contatos
sociais e, sim, da manipulação de informação sobre o seu defeito. Exibi-lo ou
ocultá-lo; conta-lo ou não conta-lo; revela-lo ou escondê-lo; mentir ou não mentir;
e, em cada caso, pra quem, como, quando e onde. ${ }^{193}$

De se dizer, aliás, que a "convivência" com o traço estigmatizante, por condicionar, de um forma ou de outra, as relações sociais entre os estigmatizados e "os outros" torna o processo de despojamento do rótulo uma atividade particularmente difícil.

Durante anos, a cicatriz, o lábio leporino, ou o nariz disforme foram considerados como um desvantagem, e sua importância nos ajustamento social e emocional

${ }^{191}$ GOFFMAN, Erving. Estigma: notas sobre a manipulação da identidade deteriorada. $4^{\mathrm{a}}$ ed. Rio de Janeiro: LTC, 1988. p.7.

192 GARFINKEL, Harold. Conditions of Successful Degradation Ceremonies. American Journal of Sociology, v.61, n.5 pp.420-424, mar. 1956. The University of Chicago Press. Disponível em: <http://www.jstor.org/stable/2773484>. Acesso em: 20 dez. 2013.

${ }^{193}$ GOFFMAN, Erving. Op. Cit., p.38. 
inconscientemente abarcava tudo. Essa desvantagem era o "cabide" no qual o paciente pendurava todas as insuficiências, todas as insatisfações, todas as protelações e todas as obrigações desagradáveis a da vida social, e do qual veio a depender não somente como forma de libertação racional da competição mas inda como forma de proteção contra a responsabilidade individual.

Quando esse fator é removido por cirurgia, o paciente perde a proteção emocional mais ou menos aceitável que ele oferecia e desde logo descobre, para a sua surpresa e inquietação, que a vida não é fácil de ser levada, mesmo pelas pessoas que tem rostos "comuns", sem máculas. Ele está despreparado para lidar com essa situação sem o apoio de uma "desvantagem" (...). ${ }^{194}$

Utilizando o exemplo acima transcrito para a realidade dos usuários de drogas, ressalta-se a importância do fortalecimento da autonomia individual em detrimento das políticas forcadas de tratamento. O indivíduo precisa construir fortes alicerces que servirão de base para a sua nova identidade sob pena de, frustrados com a implicação de sua nova identidade nas relações sociais, ou com a dificuldade dos "outros" em aceitarem seu novo papel, retornarem ao uso das drogas. Becker, citando Marsh Ray, ressalta, com exemplo específico, a dificuldade encontrada pelos ex-viciados em convencer seus pares de que estão "curados":

Marsh Ray mostrou, no caso de viciados em drogas, como pode ser difícil reverter
um ciclo desviante. Ele salienta que os viciados frequentemente tentam se curar, e
que a motivação subjacente a essas tentativas é um esforço para a mostrar a não
drogados cujas opiniões respeitam que não são realmente tão maus quanto se
pensa. Quando conseguem se livrar do seu hábito, descobrem, para sua
consternação, que as pessoas continuam a trata-los como se fossem drogados (com
base, aparentemente, na premissa de que "uma vez drogado, sempre drogado). ${ }^{195}$

Como já dissemos, será tão mais difícil despojar-se do rótulo quanto maior for a publicidade de seu "defeito". As sociedades modernas, para garantir a publicidade dos atos desviados se utiliza das chamadas "cerimônias degradantes" que, segundo o idealizador do termo, Harold Garfinkel, não muda a identidade do indivíduo, mas a reconstrói ${ }^{196}$.

Garfinkel parte da premissa de que não existe uma sociedade que não detenha condições para propiciar a degradação da identidade dos indivíduos, pelo que, propõe como tema de seu estudo a especificação dos requisitos necessários para que uma cerimônia

${ }^{194}$ GOFFMAN, Erving. Estigma: notas sobre a manipulação da identidade deteriorada. $4^{\mathrm{a}}$ ed. Rio de Janeiro: LTC, 1988, p.13.

195 BECKER, Howard. Outsiders: estudos de sociologia do desvio. Rio de Janeiro: Jorge Zahar, 2008. p. 47. 196 GARFINKEL, Harold. Conditions of Successful Degradation Ceremonies. American Journal of Sociology, v.61, n.5, pp.420-424, mar. 1956. The University of Chicago Press. Disponível em: <http://www.jstor.org/stable/2773484>. Acesso em: 20 dez. 2013. 
degradante seja bem sucedida ${ }^{197}$. Segundo a sua perspectiva, qualquer ação comunicativa que transforme a identidade pública de um autor em algo de menos valia, será considerada uma "status degradation ceremony"198.

Os processos ritualizados a que se submetem os indivíduos envolvidos com o processo criminal ${ }^{199}$ consubstanciam uma das possibilidades de cerimonias degradantes. Um dos passos mais decisivos no processo de construção de um padrão estável de comportamento desviante talvez seja a experiência de ser apanhado e rotulado publicamente de desviante ${ }^{200}$.

Daí porque é leviano o discurso que afirma que, em virtude de a norma impor aos usuários penas diferentes da privação de liberdade, estariam eles livres do estigma que pesa sobre os criminosos. A cerimônia degradante não exige, para seu sucesso, o juízo de condenação, a etapa final estabelecida por Garfinkel prevê apenas que a pessoa deve colocada num lugar relegado àqueles que vivem à margem da sociedade legítima. Como afirma Figueiredo Dias: “O julgamento criminal é a mais expressiva - mas não a única - das cerimônias degradantes”"201. A condenação pública é a cereja do bolo.

Ser abordado pela polícia, levado à delegacia, e processado perante o juízo criminal é suficiente para que se perfaça o processo de degradação do indivíduo, ensejando que nem só as outras pessoas adotem para com ele uma posição diferente, mas para que ele próprio altere sua concepção individual. As pessoas veem a si mesmas como pensam que os outros as veem, se convertem naquilo que representam, como sustentou Tannembaum, com a "dramatização do mal" 202 .

\footnotetext{
197 "It will be treated here as axiomatic that there is no no society whose social structure does not provide, in its routine features, the conditions of identity degradation. Just as the structural conditions of shame are universal to all societies by the very fact of their being organized, so the structural conditions of status degradation are universal to all societies. The question of the paper is: starting from any state of a society's organization, what program of communicative tactics will get the work of status degradation done?"

198 GARFINKEL, Harold. Conditions of Successful Degradation Ceremonies. American Journal of Sociology, v.61, n.5, pp.420-424, mar. 1956. The University of Chicago Press. Disponível em: <http://www.jstor.org/stable/2773484>. Acesso em: 20 dez. 2013.

${ }^{199}$ SHECAIRA, Sérgio Salomão. Criminologia. 2 ed. São Paulo: Revista dos Tribunais, 2008. p.297.

${ }^{200}$ BECKER, Howard. Outsiders: estudos de sociologia do desvio. Rio de Janeiro: Jorge Zahar, 2008. p.42.

${ }^{201}$ DIAS, Jorge de Figueiredo; ANDRADE, Manuel da Costa. Criminologia: o homem delinquente e a sociedade criminógena. 2. reimp. Coimbra: Coimbra Editora, 1997. p.350.

${ }^{202}$ TANNEMBAUM, Frank apud DEL OLMO, Rosa (Comp.). Estigmatizacion y conducta desviada. Maracaibo: Universidad del Zulia, 1973. p.109.
} 
Outro ponto de especial importância, que não se relaciona diretamente com o processo penal, mas que se une a ele de forma quase indissociável é o papel ocupado pela mídia, que tem repercussão fundamental na esfera da atribuição de rótulos.

Também, e talvez principalmente, a divulgação de uma condenação atribua ao condenado um estigma permanente, mas o fato é que o simples "ser processado" é suficiente para um violento processo de degradação pública, muitas vezes irreversível. Shecaira usa em seu livro o famoso exemplo Escola Base, em São Paulo ${ }^{203}$.

\begin{abstract}
Es importante observar que estas transaciones entre indivíduos desviados y agentes de control simpre han suscitado bastante interés em estra y otras culturas. Em nuestro próprio passado, tanto el juicio como el castigo a los delincuenees tenia lugar em plaza pública, dando a la multitud ocasión de participar de manera directa y activa em la ceremonia. Hy ya no exhibimos a los indivíduos desviados em la plaza pública, ni los exponemos a la atmosfera carnavalesca de Tyburn, pero resulta interessante observar que la "reforma" que inrodujo este cambio em las normas penales coincidió, com precisión matemática, com la difusión de la prensa como médio de infromación pública. Quizá no sea mas nada que uma causualidad histórica, pero sin embargo es certo que la prensa (y actualmente la radio e la TV) ofrecen a sus lectores el mismo tipo de entretenimento que ante proporcionaban las ejecuciones publicas. Uma cantidad enorme del material periodistico tiene como tema las conductas desviadas y sus castigos. ${ }^{204}$,
\end{abstract}

Dois estudos feitos no Brasil, um no Rio Grande do Sul e outro em Pernambuco, que avaliaram o papel da mídia na divulgação de notícias relacionadas ao crack constataram que o vocabulário empregado é preconceituoso e estigmatizante, que o usuário de crack, além de ser tratado como problema de saúde, é constantemente referido como problema de polícia e que, quando reforçam a ideia de tratamento, o fazem num movimento claro de enfraquecimento da autonomia individual, vendo na internação a única saída, reforçando as relações de dominação e paternalismo ${ }^{205}$.

A espécie de divulgação midiática negativa relacionada ao crack portanto, não escancara as agruras do processo penal, mas retrata a substância como avassaladora, seu uso como epidêmico e o usuário como a escória social, absolutamente desprovido de autonomia

\footnotetext{
${ }^{203}$ SHECAIRA, Sérgio Salomão. Criminologia. 2 ed. São Paulo: Revista dos Tribunais, 2008. p. 295.

${ }^{204}$ DEL OLMO, Rosa (Comp.). Estigmatizacion y conducta desviada. Maracaibo: Universidad del Zulia, 1973. p.44/45.

${ }^{205}$ Cf. ROMANINI, Moises; ROSO, Adriane. Mídia e crack: promovendo saúde ou reforçando relações de dominação?. Psicol. cienc. prof. - online, v.32, n.1, pp. 82-97, 2012 e SANTOS, Maria de Fátima de Souza; ACIOLI NETO, Manoel de Lima; SOUSA, Yuri Sá Oliveira. Representações sociais do crack na imprensa pernambucana. Estud. psicol. (Campinas) - online, v.29, n.3, pp. 379-386, 2012.
} 
individual, a ponto de a internação forcada ser, claramente, a única forma concebida de se lidar com o fenômeno.

"Eu já vi vários usuários, dependentes de cocaína, acharem que o pessoal que é dependente de crack é o fim da linha, uma conotação muito pejorativa mesmo (...)a mídia faz com que a população associe o crack à situação de vulnerabilidade social, às cracolândias, à situação de indigência, à miséria social mesmo. Então fica muito associado o crack a essa situação, quando a gente sabe que tem pessoas de outro nível também que são dependentes de crack, só atualmente tem 3 médicos aqui que são dependentes de crack, meus pacientes. E são pessoas que têm filhos, têm família, têm emprego. Não que eles estejam bem, eles não estão bem, mas não tem nada a ver com aquela situação da cracolândia. Então eu acho que é por conta de preconceito mesmo."

\section{Entrevistado E15}

“[...] você pega um usuário de crack. Você pergunta para qualquer pessoa na rua, o que ele vai pensar: "Deus me livre. Está quase em condição de uma pessoa excluída socialmente, a maior parte fica em situação de rua, fica naquelas casas abandonadas. Vem aquela imagem meio que parece caracterizada como mendigo. Se arrastando pela rua."

\section{Entrevistado E5}

Segundo Becker, o grau em que outras pessoas reagirão a um ato dado como desviante varia enormemente. A ocorrência de "campanhas" contra vários tipos de desvio ilustra isso claramente ${ }^{206}$. É obviamente muito mais perigoso envolver-se numa dessas atividades quando uma campanha está em curso que em qualquer outro momento ${ }^{207}$. Ser usuário de crack num tempo em que o Governo Federal destina 4 milhões de reais a um programa denominado "Crack: é possível vencer”, não parece a melhor das escolhas.

\footnotetext{
206 Num estudo muito interessante sobre notícias a respeito da criminalidade nos jornais do Colorado, Davis descobriu que a quantidade de crimes noticiados nos jornais do estado mostrava muito pouca associação com mudanças reais na quantidade de crimes que ocorriam no território. E, além disso, que a estimativa das pessoas sobre o aumento da criminalidade no Colorado estava associada ao aumento na quantidade de notícias de crime, não a qualquer aumento na quantidade de crimes. (BECKER, Howard. Outsiders: estudos de sociologia do desvio. Rio de Janeiro: Jorge Zahar, 2008. p.25)

${ }^{207}$ Ibidem, p. 25.
} 
Aliando a essas constatações o discurso de Goffman brevemente desenvolvido nesse trabalho sobre os desacreditáveis e os desacreditados, em que os primeiros tem como questão fundamental da vida a manipulação de informação sobre o seu defeito, pode-se aventar a possibilidade de que os usuários, não tendo mais a possibilidade de escolha - e aqui nos referimos aos dependentes - entre usar ou não o crack, podem esforçar-se em ao menos tentar esconder esse defeito, para que, de desacreditáveis, não passem ao círculo dos desacreditados.

Eles sabem que, uma vez atribuído o rótulo de drogado, será difícil despojar- se dele:

“Não é mais tolerado esse lance que 'uma vez drogado sempre drogado'. Nós nos recuperamos. São alguns slogan que eu trago pra minha vida. A sociedade muitas vezes - eu tô falando no uso - aplaudia: "Vai morrer lá”, né? Mas a grande realidade é uma carência enorme que nos faz, que me faz-fazia, né? , usar droga. Um complexo louco que até hoje... A procura da batida perfeita, mas não tem, né? Então assim. O culpado, se tem um culpado, sou eu. Mas eu tenho que diminuir essa culpa cada vez mais pra me manter limpo. É existencial... né?"

\section{Entrevistado P1}

Citando o pensamento de Hughes, Becker alerta também que o status de desviante é definido como status principal da pessoa e essa identificação prova-se como mais importante que as outras. A identificação desviante torna-se a dominante. "Tratar uma pessoa como se ela fosse em geral, e não em particular, desviante, produz uma profecia auto realizadora. Ela põe em movimento vários mecanismos que conspiram para moldar as pessoas segundo a imagem que os outros tem dela ${ }^{208}$.

"Sempre quando eles vão se apresentar, eles nunca falam as coisas que eles fazem, a profissão que eles têm. Eles sempre associam seu nome com o uso da droga que eles utilizam."

\footnotetext{
${ }^{208}$ BECKER, Howard. Outsiders: estudos de sociologia do desvio. Rio de Janeiro: Jorge Zahar, 2008. p. 44.
} 


\section{Entrevistado E2}

"Parece que a identidade deles fica restrita a ser dependente químico. A gente observa, assim, pelos grupos. Pede para apresentar: "Eu sou fulano, tenho tantos anos e sou dependente de álcool, crack, sei lá o que”. Então, assim, o que mais? Você também é dependente, mas fica muito restrito, fica muito diretamente relacionado. Meu nome é isso e também sou dependente químico. De também estar aqui. Você percebe que quando você fala o nome 'droga', qualquer questão que você vai fazer, eles já se identificam totalmente. E parece que todo o resto da vida não é tão importante quanto."

Entrevistado E6

Se a divulgação de uma campanha tão imbuída de rótulos estigmatizantes pode ter efeitos tão negativos sobre os pretenso destinatários dela, por que insistir na manutenção desse tipo de abordagem? Logo no início desse capítulo, ao mencionarmos os acontecimentos sociais ocorridos nos Estados Unidos na década de 60, discorremos sobre os movimentos de contra cultura que questionavam, em suma, os valores vigentes numa sociedade que dizia-se do consenso. Nasce, portanto, o dissenso.

Dissemos também que a esses movimentos se sucedeu uma intensa onda de criminalização nova, ligada ao controle dos movimentos sociais e de ações contestadoras, o que abriu caminho para o desenvolvimento de uma teoria que analisava o impacto negativo da reação social frente ao desvio.

Quando alguém questiona a norma através de sua violação, a reação social negativa tem um impacto comunicativo muito grande à medida que afirma a validade da norma violada. "Siempre que el grupo censura um acto determinado como desviado, consolida la autoridade de la norma violada y por el mismo enjuiciamiento ratifica la delimitacion de espacio social". ${ }^{209}$ Da mesma forma que quando o governo elege um inimigo comum, a sociedade pode se unir em torno do combate desse inimigo.

${ }^{209}$ DEL OLMO, Rosa (Comp.). Estigmatizacion y conducta desviada. Maracaibo: Universidad del Zulia, 1973. p.44. 
Desenvolver políticas sérias e comprometidas com a questão das drogas no geral é trabalhoso e muito provavelmente os resultados não serão visíveis antes do próximo período eleitoral, de modo que a política fica cindida, datada e ineficaz. Como diz Zaffaroni, "os políticos - presos na natureza competitiva de sua atividade - deixam de buscar o melhor para preocupar-se só com o que possa transmitir-se melhor e aumentar sua clientela eleitoral." ${ }^{210}$

${ }^{210}$ ZAFFARONI, Eugenio Raul; OLIVEIRA, Edmundo. Criminologia e Política Criminal. Rio de Janeiro: GZ Editora, 2010. p.34. 


\section{A Repressão Penal sobre o Usuário de drogas como fator de AproximaÇão/Afastamento do Tratamento. A CoerênCia entre os Fins Almejados Pela Política de Drogas e sua Aplicação Prática.}

Como já afirmamos durante todo o trabalho, com o advento da Lei no 11.343/06, restou fortalecida a ideia de que o usuário de drogas deve ser encarado como pessoa que necessita de cuidados, e não somente da atuação do aparelho repressivo estatal.

Esse posicionamento, que reflete uma política de atenção, é facilmente observado pela redação dos dispositivos legais da norma, como por exemplo "Esta Lei institui o Sistema Nacional de Políticas Públicas sobre Drogas - Sisnad; prescreve medidas para prevenção do uso indevido, atenção e reinserção social de usuários e dependentes de drogas [...]" (art. $1^{\circ}$, Lei n ${ }^{\circ} 11.343 / 06$, g.n.), bem como pelo reconhecimento da redução de danos como um dos objetivos a serem perseguidos pela política de drogas "Constituem atividades de atenção ao usuário e dependente de drogas e respectivos familiares, para efeito desta Lei, aquelas que visem à melhoria da qualidade de vida e à redução dos riscos e dos danos associados ao uso de drogas" (art. 20, Lei n $\left.{ }^{\circ} 11.343 / 06\right)$.

Como expressão máxima do abandono de um modelo exclusivamente repressivo, temos o rechaçar da pena privativa de liberdade como resposta adequada à conduta praticada pelo usuário de drogas, uma vez que os efeitos nefastos decorrentes desse tipo de resposta penal acabariam por agravar a situação desses indivíduos que, já expostos aos efeitos da substância, bem como aos riscos decorrentes da situação de violência enfrentada em virtude do uso - pelo status de ilegal do item consumido - estariam também sujeitos às agruras da passagem pelo sistema carcerário.

Importa ressaltar novamente que, na prática, já era pouco comum que os usuários de drogas fossem apenados com penas privativas de liberdade, tanto pelos institutos penais de substituição de pena quanto pela possibilidade de transação penal, a partir de 2001, ano em que a Lei que institui os Juizados Especiais Criminais Federais ampliou para dois anos o patamar máximo de pena para que uma infração fosse considerada de menor potencial ofensivo. 
Não obstante a isso, o abandono da pena privativa de liberdade - diga-se: a resposta penal por excelência - como consequência adequada para reparar e prevenir uma infração penal, tem significado importante no que se refere ao status atribuído à conduta de portar drogas para uso próprio. Tão importante que gerou alguma confusão na doutrina específica, que chegou a aventar a possibilidade de ter havido a descriminalização do porte de drogas para uso pessoal. ${ }^{211}$

Muito embora a controvérsia parecesse ter sido sanada com o julgamento do Recurso Extraordinário $\mathrm{n}^{\mathrm{0}} 430.105 / \mathrm{RJ}$, pelo Supremo Tribunal Federal ${ }^{212}$, o fato é que a doutrina majoritária, embora concorde com a tese de que o porte de drogas para consumo permanece classificado como infração penal, em virtude da previsão de aplicação apenas de penas alternativas à prisão, ainda faz afirmações sobre a retirada do usuário do rol dos criminosos. Por mais contraditório que pareça, não é raro encontrar textos que, embora reconheçam a natureza criminosa da conduta do usuário, afirmem que "sob o usuário não pesa mais o rótulo de criminoso" ou que "o usuário não é assunto de polícia", como afirmou nosso Ministro da Saúde no lançamento do programa “Crack: é possível vencer”.

Como exemplo dessa aparente confusão, citaremos, a título de ilustração e para facilitar a construção do raciocínio, trecho da obra coordenada por Marcelo Ovídio Lopes Guimarães sobre a Lei $\mathrm{n}^{\mathrm{o}} 11.343 / 06^{213}$, muito embora o autor ainda reconheça o porte de drogas para uso pessoal como infração penal, na qual são elencados os efeitos funestos da penalização do uso de entorpecentes, como se o abandono da pena de prisão fosse suficiente para extingui-los, o que, a partir do embasamento metodológico exposto neste trabalho, não parece ser uma abordagem eficiente para a análise holística desta temática, conforme buscamos abordar neste trabalho.

${ }^{211}$ GOMES, Luiz Flávio (Org.). Lei de Drogas Comentada. Lei no 11.343/06. 3 ed. São Paulo: Revista dos Tribunais, 2013.

212 BRASIL. Supremo Tribunal Federal. Acompanhamento processual. Recurso Extraordinário RE 430.105/RJ. Disponível em:

<http://www.stf.jus.br/portal/processo/verProcessoAndamento.asp?incidente=2228314. Acesso em:

10 jan. 2012.

${ }^{213}$ GUIMARÃES, Marcelo Ovídio Lopes (Org.). Nova Lei Antidrogas Comentada - Lei no 11.343/06. São Paulo: Quartier Latin, 2007. 
Dentre todos os efeitos nocivos então elencados em referida obra, temos: a) o fruto proibido resulta atrativo entre os jovens; b) a ilegalidade do ato torna a mercadoria excessivamente cara, o que passa a ser um rendimento altamente lucrativo para alguns, fazendo até com que se proporcionem, gratuitamente, as primeiras doses, a fim de obter dependentes; c) proporciona o contato dos jovens com os traficantes; d) usuários acabam delinquindo para poder adquirir dinheiro para financiar o hábito, inclusive realizando o tráfico; e) arriscam-se, muitas vezes, a um constante perigo de mote e enfermidade; f) em relação aos demais cidadãos: de um terço à metade de todos os delitos violentos contra a propriedade são cometidos por drogados que delinquem para financiar seu habito, ou se devem a conflitos entre grupos rivais de traficantes de drogas, ou se realizam no transcurso da importação e distribuição de drogas ilegais; g) é uma causa básica de corrupção policial; h) não há controle de qualidade da mercadoria, o que produz, muitas vezes, danos irreparáveis aos consumidores; i) deve-se aceitar a derrota e entender e inexiste ação capaz de eliminá-lo; j) na prisão, o consumo e o tráfico continuam existindo ${ }^{214}$, o único que nos parece afetado pelo abandono da pena privativa de liberdade é a continuidade da existência do consumo e do tráfico na prisão, já que na nova realidade dos usuários, não existe mais a ameaça de prisão (senão aquela arbitrária pela classificação como tráfico do que deveria ser apenas uso, o que já foi mencionado).

Em outras palavras, o que se pretende deixar aqui claro é que, não obstante a previsão de medidas alternativas à privação de liberdade como resposta ao porte de drogas para uso pessoal seja um avanço, essa postura não solucionou o problema dos efeitos negativos que a criminalização do usuário produz e a manutenção do status de infração penal à conduta do usuário pode ter efeitos negativos na procura pelo tratamento, o que, pelo menos pela redação do texto normativo e pelo discurso dos porta vozes oficiais do Estado, parece ser o objetivo primeiro da nossa política de drogas.

Essa confusão sobre o status da conduta - se criminosa ou não - atinge tanto os profissionais que lidam com o tema, quanto os próprios usuários, que temem serem punidos apenas pelo tráfico, sendo certo que muitos ignoram o fato de que portar drogas para seu

\footnotetext{
${ }^{214}$ GUIMARÃES, Marcelo Ovídio Lopes (Org.). Nova Lei Antidrogas Comentada - Lei no 11.343/06. São Paulo: Quartier Latin, 2007.
} 
consumo próprio continua sendo infração penal. A título de ilustração, o trecho da entrevista a seguir, realizada com um usuário, deixa clara a surpresa:

Pesquisadora: Mas você tem medo de ser presa por tráfico? Ou de cumprir aquelas medidas alternativas? P11: Eu tenho medo de ser presa por tráfico, porque é inafiançável, não é? Pesquisadora: Mas e cumprir as medidas do uso... P11: Como assim? Pesquisadora - Porque portar droga para uso pessoal é crime também. Só que eles deveriam te levar para a delegacia, fazer um termo circunstanciado e aí eles podem aplicar três tipos de medida que é comparecimento obrigatório a cursos sobre os efeitos das drogas, prestação de serviços à comunidade ou advertência. P11: Mas se tiver com 3 pinos e eles me pegarem eu posso...Pesquisadora: Pode. São essas três medidas. Não é cadeia. Não tem pena de prisão. Mas você pode ser condenada a prestar serviço à comunidade. Você não sabia? P11: Não sabia. Não sabia. Pesquisadora: Mas o porte para uso também é crime. Então, se você não sabia não dá para ter tido medo, não é? P11: Nossa. Agora vou ficar com medo. Pesquisadora: Qualquer quantidade de droga. P11: Até um baseado? Uma paranga? Até uma paranga? Pesquisadora: Por isso que eu te perguntei se eles te enquadravam e te levavam para a delegacia. Você disse que eles jogam fora, mas não é. Na verdade, eles estão prevaricando, porque a obrigação deles seria te levar para a delegacia. P11: Mas essa lei entrou quando? Pesquisadora: Em 2006. P11: Nossa. Não sabia. Não sabia, gente. Pesquisadora: A lei anterior era pena de prisão para usuário. E aí, a lei, desde 2006, são essas medidas alternativas. P11: Ah, não sabia disso. Eu achei que, tipo assim, pegar com 6 entorpecentes já era tráfico. Pesquisadora: O tráfico não é só quantidade. São outros fatores também. Onde você está. Se é ponto de tráfico, se não né. Se você tem histórico, se não tem. O tanto de dinheiro que você tem na bolsa. Se o dinheiro está picado. Se a droga está em porções pequenas ou está numa porção maior. Então, tudo isso é considerado para o tráfico. Você ia usar aqueles pinos, não ia? Ou você ia vender? P11: Eu ia usar [...] P11: Nossa, eu não sabia! Caraca! Nossa, eu não sabia! Vou falar para todo mundo isso daí agora. 
O ponto de partida, portanto, da análise pretendida nesse capítulo é compreender que muito embora a lei tenha operado um avanço quando retirou do rol de penas previstas para o porte de drogas para uso pessoal a pena de privação de liberdade, esse movimento não foi suficiente para afastar todas as demais implicações decorrentes da inserção de uma conduta na esfera dos ilícitos penais. Tendo sido a questão já dirimida pelo Supremo Tribunal Federal, o indivíduo que porta drogas para seu consumo está cometendo um crime. Será ou deveria ser - abordado pela polícia, levado à delegacia e submetido ao procedimento processual penal adequado para o processamento da infração, com todas as consequenciais penais e processuais penais relacionadas.

Partindo dessa premissa e considerando que a atual política de drogas brasileira tem como objetivos últimos a "atenção e reinserção social do usuário", como declarado pelo texto da norma vigente, seria possível deduzir que atividade repressiva direcionada ao usuário seria meio para a consecução desse fim. Caso contrário, estaria expresso no texto normativo, como acontece, por exemplo, com o tráfico, o objetivo da repressão dessa conduta.

É dessa constatação que surgiu a dúvida que deu ensejo ao presente estudo: será que a atividade repressiva pode atuar de forma coerente com uma política pública que objetiva o cuidado direcionado aos usuários de drogas? Para que a resposta fosse positiva, bastaria a constatação de que o exercício da repressão penal não tem efeitos negativos sobre a política de atenção aos usuários, mas não foi o que aconteceu.

A criminalização do porte para uso é o que viabiliza que os usuários de drogas sejam abordados pelas polícias civil e militar, que tem como atribuição, respectivamente, as funções de polícia judiciária e a apuração de infrações penais (art. 144, § $4^{\circ}$, da CF) e a polícia ostensiva e a preservação da ordem pública (art. 144, § 4º da CF).

Policiais têm, por essência, atuação repressiva. Se os usuários, ao contrário do que sustentam alguns, permanecem sendo questão de polícia, seria através desse tipo de abordagem que a nossa política de drogas pretenderia promover atenção e reinserção social de usuários e dependentes de drogas" ? (art. 1º Lei n 11.343/06, g.n.) Foi esse, como já exaustivamente explicitado, o mote da presente pesquisa: qual a coerência entre os fins 
declarados pela política nacional de drogas e os meios estabelecidos pela legislação para sua consecução.

Pois bem. Os usuários de crack entrevistados para fins deste trabalho, quando perguntados sobre as experiências que tiveram com a polícia, relatam situações de constrangimento e violência:

Pesquisadora: E você acha de algum jeito que essa abordagem da Polícia te fez pensar...? P3: A PM não. Já aconteceu de eu ser abordado pela PM e eles serem bem truculentos e mal educados.

\section{Entrevistado P3}

Pesquisadora: Entendi. Você já teve alguma experiência com a Polícia? P7: Enquadras, várias. Pesquisadora: Em vários enquadros? P7: Vários. Pesquisadora: E como foi a experiência? P7: Esculachando, não é? Batem, humilham, xingam de tudo o que é nome e falam que a gente é um lixo; que a gente é raça que não podia viver... Essas coisas assim. [...]Pesquisadora: Você tem marcas? P7: Marcas de Polícia.

\section{Entrevistado P7}

Pesquisadora :Tá. Agora vem a pergunta. Você já teve alguma experiência com polícia? P8: Várias. Pesquisadora: Como foram? P8: Eu, como sou branquinho, tenho uma boa aparência e tudo, nunca... Nunca não, não vou dizer 'nunca', não fui tão esculachado pela Polícia, né? Mas já tomei tapa na cara, já tomei murros, já me ameaçaram de me matar várias e diversas vezes. [...]Pesquisadora: E geralmente eles falam o quê? P8: Te xingam de tudo quanto é nomes. Te batem. Te agridem psicologicamente de todas as formas possíveis. Chegou uma vez, um policial ameaçou a fazer roleta-russa comigo. Sabe? Ele virou... Pesquisadora: E por quê? Qual era a situação? P8: Por prazer sádico de maltratar um outro ser humano.

Entrevistado P8

Pesquisadora: Fora essa experiência que você teve com a polícia, por causa da sua mãe. Você já teve alguma outra experiência com a polícia por causa da droga? Já tomou enquadro? P11: Ah vários. Vários. Várias vezes já me enquadraram, já pegaram 
a minha droga. A Guarda Civil Metropolitana. São Caetano. Várias vezes já pegou minha droga. Uns jogam fora, outros cheiram na minha frente. Por exemplo, cocaína. Já me pegaram várias vezes com cocaína, guarda civil. Colocavam no carro mesmo e falavam: "Olha,[...]. Que legal”. Cheiravam na minha frente. Outros jogavam fora [...] P11: Já. Rota já me parou. A Rota é um pouquinho mais... Já me pegou com uns pinos, aí jogaram fora. Pesquisadora: A Rota é um pouco mais o que? P11: Um pouco mais... Pesquisadora: Truculenta? P11: É. Eles cheiram, todos os caras da Rota. Eles chegam com a arma na sua cabeça, sabe? Você fica meio em choque.

\section{Entrevistado P11}

Dentre os profissionais, também foi relato da maioria que os pacientes, quando contam sobre alguma experiência com a polícia, fazem referência a experiências negativas e traumatizantes:

Pesquisadora: E algumas das pacientes já relataram alguma relação com polícia ou Justiça? E3:Todas. Todas. A maior parte, porque uma das coisas principais aí não é a peculiaridade das mulheres. De quando você começa a ter muito, assim, a fazer um uso compulsivo, você acaba sendo pego pela polícia. Nossa, elas relatam direto o abuso, a agressividade, a violência, a manipulação. Todas. Pesquisadora: Então, nunca um relato acompanhado de uma reflexão positiva? E3: Polícia? Polícia para dependente químico? Polícia é bandido para dependente químico. Polícia usa eles, polícia bate neles, polícia rouba drogas deles.

\section{Entrevistado E3}

Pesquisadora: Entendi. E aí você falou do policial eventualmente com uma postura acolhedora. Existem relatos dos pacientes sobre os policiais? Geralmente eles relatam... E5: Olha, os poucos casos, os casos que eu atendi, dificilmente eu ouvi alguma postura de um policial acolhedor. Pesquisadora: Como é a postura de um policial? E5: Geralmente repressão. De repressão, de fazer aquela abordagem que eles fazem, de fazer...

\section{Entrevistado E5}

Pesquisadora: Você acha que os usuários se sentem lesados? Você já ouviu... Dos relatos que você já deve ter ouvido da relação deles com a polícia ou com a Justiça, os relatos são de uma relação cidadã ou de um abuso? E7: De abuso sempre. De abuso. 
E eles ficam muito indignados, porque no mundo deles, eles conhecem quem usa. Então, eles sabem que muitos daqueles policiais que estão ali abusando do poder, também estão sob o efeito de algum tipo de... Que seja álcool, o que for, de entorpecente, outra coisa. Então, eles se sentem muito mal com isso, com esse abuso. Quem é o cara? Sabe aquela história do espelho? Então, o pai quer fazer tudo bonitinho para o filho seguir o modelo. Só que daí ele faz umas coisinhas tortas por trás, tentando esconder do filho. Acaba dando esse choque. Eles se sentem abusados totalmente, até porque a gente sabe de relatos, inclusive, da pessoa não estar nem aí com nada. Não sei o que. É uma pena. Não são todos, mas a gente vive hoje num mundo muito corrupto. Então, o dinheiro vai falar sempre mais alto. Infelizmente, acho que por conta desse capitalismo, tudo isso, se vive em função disso, não é? "Ah, mas coitado. O policial ganha pouco". Ele escolheu aquela profissão. Existe uma diferença entre as pessoas que fazem por amor e as pessoas que fazem por outros motivos, sejam eles quais forem, inclusive, eu não sei, eu sempre olho para a polícia, eu vejo casos acontecendo que eu fico pensando: “Meu Deus. Que tipo de seleção que essa pessoa passou?" Porque um policial que joga álcool numa pessoa e ateia fogo e vai dizer que foi acidente, ele se machuca e mata uma pessoa queimada. Não sei. É isso que é Justiça? É isso que é lei?

Entrevistado E7

Pesquisadora: E algum, não sei se você já teve algum paciente que tenha relatado alguma experiência com polícia para saber se eles relatam uma experiência de aconselhamento, mais de colaboração ou algo mais violento e agressivo? E9: Então, na verdade, dos poucos que eu ouvi falar, porque foram bem poucos aqui no PROAD, no grupo mesmo foi uma atitude um pouco mais ofensiva, mais punitiva, que gera certo receio. Gera um certo medo. Não posso confiar em polícia. Mais fácil confiar no traficante, do que... Mais fácil confiar no tráfico do que na polícia.

Entrevistado E8

Pesquisadora: E os seus pacientes, quando trazem algum relato, se já trouxeram de contato com polícia, é um contato que se desenvolve de que forma? E10: Agressiva. Pesquisadora: Sempre agressiva. E10: Nunca é positiva. Nunca é como: "Ah, o policial veio e me ajudou a ir para o tratamento". É sempre: "Eu fui preso e ai levei muita porrada, e aí eu saí e aí usei mais por um tempo e agora estou melhorando. Aí vim procurar tratamento".

Entrevistado E10 
E11: [...] Tem também muitos pacientes que trazem relatos da polícia e o relato da polícia, relato de um contato sempre muito agressivo, principalmente da Rota, que é ofensivo, é humilhante, que eles têm ou não tem isso muito com adolescente, ou seja, quem está vulnerável. Mulheres, adolescente, crianças, é sempre um relato ruim. É sempre um relato negativo. É sempre muito... É um contato ruim e que não é convidativo. A polícia não chega e aí de repente acolhe essas pessoas iriam para algum lugar de tratamento. Não. É sempre no sentido de fiscalizar e de, de repente prender e de repente ofender ou assustar. É sempre nesse sentido. Pesquisadora: Mesmo quando existe, por exemplo, a prisão ou a forma de conduzir não é respeitosa. E11: Nunca.

Entrevistado E11

Pesquisadora: Os usuários que passaram por você, muitos relataram alguma relação com polícia ou com o Poder Judiciário? E12: Sim. Pesquisadora: E como geralmente é esse relato? É um relato de uma situação que enseja uma reflexão, uma situação de acolhimento ou uma situação desagradável, agressiva? E12: Coisa ruim, na maioria das vezes falam: "Eu escapei dessa", e quando não escapam é uma coisa, em geral, bastante traumática.

Entrevistado E12

Pesquisadora: Você já teve muitos pacientes que relataram algum contato com a polícia ou com o Poder Judiciário? E13: Mais no PROAD do que no consultório particular. Muito mais no PROAD que no consultório particular. Pesquisadora: E, geralmente, vem como esse relato, no sentido de uma aproximação que ensejou uma reflexão, que teve algum efeito positivo, que reforçou algum tipo de vínculo, teve uma responsabilização positiva ou num sentido de agressão, ofensa, um ponto mais negativo, na verdade? E13: Olha, eu não sei se tem um viés da minha memória, porque os casos que me marcaram foram os casos em que houve um contato negativo. Então eu lembro muito de pacientes que foram presos por conta do uso ou por conta de crimes associados ao uso, roubou para usar, estuprou porque estava sob efeito, que é uma coisa questionável, mas enfim, sempre de forma muito negativa. E tem alguns pacientes que eu tenho essa imagem muito marcante, de terem passado pela polícia, de terem sido presos, e terem uma história de várias idas e vindas nesse contato com a polícia sempre de forma muito negativa. Eu sei que para todos os pacientes no PROAD a gente pergunta se eles já tiveram algum tipo de contato com a polícia no momento que ele chega. Eu sei que muitos pacientes dizem que sim, mas me parece que fica numa... A gente não aprofunda em como é que foi esse contato nessa primeira entrevista. E pelo 
menos nessa primeira entrevista fica a impressão de ser uma coisa um pouco neutra. Contato positivo eu nunca vi de verdade, eu nunca vi.

Entrevistado E13

Pesquisadora: É comum que os pacientes, e aí eu te peço para pensar um pouco mais nos pacientes de crack só porque eu restringi o estudo a eles, é comum que eles tragam algum relato de contato com a polícia? E15: Frequente, muito frequente. Mas isso está mais relacionado com as populações mais desfavorecidas. Porque o pessoal de população mais favorecida, eles têm mecanismos de controle disso. E o pessoal que está nessa situação de 'cracolândia', que é uma situação de muita visibilidade, muita vitrine, eles estão expostos, eles ficam mais vulneráveis a isso. Pesquisadora: E os relatos de contato com a polícia geralmente são positivos ou negativos? E15: Muito negativos, é de agressão, de violência.

Entrevistado E15

Esses tipos de eventos traumáticos aprofundam a vulnerabilidade do indivíduo, bem como o seu o distanciamento do aparato oficial, que é visto como expressão apenas da repressão, uma vez que, na maior parte dos casos, esse é o único contato que eles tem com o poder estatal.

Bruno Ramos Gomes ${ }^{215}$ e Rubens de Camargo Ferreira Adorno ${ }^{216}$ publicaram em
outubro de 2011 artigo intitulado "Tornar-se 'nóia': trajetória e sofrimento social nos 'usos

215 Possui graduação em Psicologia pela Universidade Presbiteriana Mackenzie (2006), e mestrado em Saúde Pública pela Faculdade de Saúde Pública da USP. Atualmente é coordenador e presidente do Centro de Convivência É de Lei, além de psicólogo clínico e Acompanhante Terapêutico. Atua principalmente nos seguintes temas: drogas, redução de danos, vulnerabilidade, crianças e adultos em situação de rua, direitos humanos. Disponível em: <http://buscatextual.cnpq.br/buscatextual/busca.do>. Acesso em: 03 jan. 2014.

216 Professor Associado III na Universidade de São Paulo, possui graduação em Ciências Sociais pela Universidade Estadual de Campinas (1977), Mestrado em Saúde Pública pela Universidade de São Paulo (1992) Doutorado em Saúde Pública pela Universidade de São Paulo (1992), e Livre Docente pela mesma universidade em 1997, vem atuando na linha de pesquisa: Saúde Pública, Ciências Sociais e Sociedade Contemporânea; que procura trazer a contribuição da Pesquisa Social, notadamente da Antropologia e das etnografias contemporâneas, para o campo da Saúde, buscando construir um tratamento teórico para as vulnerabilidades contemporâneas que possam se expressar a partir dos contextos que se constituem no capitalismo tardio e articulam os contextos globais, nacionais e locais, do cotidiano e das mudanças que ocorrem na vida das populações a partir de seus contextos e dos recortes classe social, raça-etnia, geração, gênero e sexualidades e curso de vida. Disponível em: 〈http://buscatextual.cnpq.br/buscatextual/busca.do>. Acesso em: 03 jan. 2014. 
de crack’ no centro de São Paulo ${ }^{217}$ ", oriundo de pesquisa etnográfica realizada durante cerca de cinco anos na região paulistana conhecida como "Cracolândia".

No texto, os autores deixam consignado que a aproximação entre pesquisadores e usuários se deu de forma peculiar, pois realizada através de agentes de redução de danos da ONG chamada "Centro de Convivência É de Lei",218 e, portanto, desvinculados do poder estatal:

\begin{abstract}
Importante destacar que a relação com as pessoas neste local aconteceu através de idas a campo junto com agentes de redução de danos de uma organização não governamental chamada Centro de Convivência É de Lei.1 Este serviço mantém um tipo de relação de proximidade com os usuários que não se insere no projeto governamental de requalificação da área, em que participam os outros agentes da prefeitura. $\mathrm{O}$ distanciamento do aparato oficial possibilita à $\mathrm{ONG}$ um acesso diferenciado aos usuários de crack. Este tipo de acesso e o tipo de diálogo que permite estabelecer com eles serão discutidos mais adiante no texto ${ }^{219}$.
\end{abstract}

Como se sabe, a região da "Cracolândia" sofreu, nos últimos anos, ações repressivas que tinham como objetivo cessar o tráfico e o uso de drogas na região o que, segundo os pesquisadores, fez com que os usuários dividissem os diferentes grupos que trabalham na região "de forma polarizada: existem aqueles que estão "do lado deles", e os que estão "contra eles", do lado da polícia" ${ }^{220}$. Como o trabalho do redutor de danos não é bem visto pela polícia e muitas vezes os profissionais são revistados junto com os usuários, é comum que eles sejam vistos como pessoas que estão do seu lado, pois tratados da mesma forma, "o redutor é percebido também como alguém que está ali para interferir na existência deles, surgindo assim a ideia de cuidado"221.

Essa polarização atrapalha a atuação dos agentes de saúde, uma vez que esse contato oficial repressivo gera receio nos usuários que acabam procurando os agentes oficiais apenas para tratarem questões pontuais, como uma ida ao hospital, sem, contudo, estabelecer a

\footnotetext{
${ }^{217}$ GOMES, Bruno Ramos; ADORNO, Rubens de Camargo Ferreira. Tornar-se "noia": trajetória e sofrimento social nos "usos de crack" no centro de São Paulo. Etnográfica, v.15, n.3, p.569-586, 2011.

${ }^{218}$ O Centro de Convivência É de Lei surgiu no final da década de 1990 com o objetivo de desenvolver estratégias de redução de danos sociais e à saúde relacionados ao uso de drogas. Caracteriza-se como um espaço de sociabilidade e acolhimento para pessoas que usam drogas e por ações nas regiões de uso de drogas na cidade de São Paulo. Para mais informações, cf. 〈http://edelei.org/>.

${ }^{219}$ GOMES, Bruno Ramos; ADORNO, Rubens de Camargo Ferreira. Op. Cit., p. 570.

${ }^{220}$ Ibidem, p. 573.

${ }^{221}$ Ibidem, p. 573.
} 
relação de confiança necessária para que que se inicie um processo de conscientização sobre o uso da droga:

\begin{abstract}
Outros serviços, como os dos agentes comunitários de saúde e agentes da assistência social, conseguem uma aceitação diferente por parte dos usuários, que acabam recorrendo a eles para questões pontuais e concretas, como ajuda para ir ao hospital, por exemplo. Estes agentes são vistos como agentes da municipalidade que, na verdade, oferecem pouca acolhida, e muitas vezes passam a ser vistos como mais uma força que intervém para retirá-los do espaço. São vistos como aliados da polícia e em oposição aos usuários. Observa-se um movimento dos agentes de saúde buscando se distanciar das ações policiais para mudar isso, porém a constante pressão da atual gestão municipal para que retirem os usuários dali rapidamente dificulta o acolhimento e aproxima os agentes da polícia, no ponto de vista dos usuários ${ }^{222}$.
\end{abstract}

Essa ideia de que a atuação repressiva contra os usuários, principalmente no primeiro contato, os afasta do tratamento, ficou evidente nas entrevistas realizadas com os profissionais da equipe multidisciplinar do serviço onde foram realizadas as entrevistas. Importa, no entanto e mais uma vez, ressaltar que a ideologia do PROAD é marcada pela liberdade e pelo fortalecimento da autonomia dos indivíduos, pelo que a pesquisa pode ter sido direcionada por esse pensamento:

“Pesquisadora: E aí, dentro desse contexto de uma aproximação de serviço social, você acho que o primeiro contato, através da repressão, afasta ou aproxima o indivíduo? E1: Afasta. Afasta totalmente, porque você entra por outro viés. Você entra pela imposição e pela força. E não pelo acolhimento. Porque essa pessoa que está na rua não tem família. Ela perdeu a perspectiva de vida, não tem nenhum objetivo pelo qual ela pode ser movida a sair dali. Se a gente fortalecer esse outro lado social dela, que seja um prato de comida, um lugar para ela dormir, tomar banho, um trabalho, eu acho que é mais por aí que a gente tem abordar no início. Não sei nem se é no início. Acho que todo o tratamento".

\title{
Entrevistado E1
}

\footnotetext{
${ }^{222}$ GOMES, Bruno Ramos; ADORNO, Rubens de Camargo Ferreira. Tornar-se "noia": trajetória e sofrimento social nos “usos de crack” no centro de São Paulo. Etnográfica, v.15, n.3, p.569-586, 2011, p. 573.
} 
“Pesquisadora: [...] dentro dessa ideia, pensando numa primeira abordagem de uma mulher, já que a gente está falando das mulheres, usuárias de crack, você acha que uma primeira abordagem repressiva pode afastar? E3: Claro que afasta. É óbvio. Sim, também, você sabe. A política do PROAD... A repressão aproxima quando? Eu acho que não é com respeito ao crack. Eu acho que é com respeito a qualquer outra coisa. Se você quer que alguém venha te procurar, você acolhe. Se você começa já a botar o dedo no nariz da pessoa, é óbvio que ela não vem te procurar. Ela está frágil, ela está precisando de ajuda, ela está com vergonha. Vem alguém já mostrando: "Que vergonha”. O que você faz? Você vai embora. Você foge. Essa é a pior política que você pode querer ter para alguém vir buscar ajuda. [...] Existem certos comportamentos, certos tipos de defesa que se você bater de frente, foge. Esse tipo de comportamento do usuário, que é um comportamento delinquencial, vamos dizer assim, ele tem a ver. É um comportamento delinquencial porque você está fazendo uma coisa contra a lei, para os usuários de crack, não é? [...] Agora, se você vai tratar, fazer a clínica de um determinado tipo de comportamento que acompanha todo usuário ide drogas que é “delinquencial”, ou seja, vocêfaz alguma coisa errada usando o seu ego. O ego vai junto com você. Usa a sua vontade também para fazer. Então, a gente chamaria "comportamento que tem muitas defesas psicopatias", ou seja, antissociais. Por que antissociais? Porque é errado para a sociedade. E você vai reprimir essa pessoa? O que ela vai fazer? Ela vai espanar. Ela vai embora. O que você tem que fazer é: "Ok, nós sabemos que está errado. Aqui tem espaço para aguentar e para trabalhar isto que não é correto, que você está fazendo. Você traz para mim que não é correto, eu estou tentando te ajudar. Mas se você vem buscar tratamento, é porque vocêé dependente. Senão você não viria”. Agora, se eu vou dizer: "Não pode. Vou te reprimir", você vai embora".

\section{Entrevistado E3}

"E4: Eu acho que a repressiva tem menos chance de dar certo. Acho que afasta sim a possibilidade de coisas interessantes, entendeu? De tratar, de... Sei lá. Eu acho que uma abordagem mais acolhedora, uma coisa mais compreensiva da situação daquele indivíduo que não está usando crack porque simplesmente 
quer usar crack. Isso é uma incontingência da vida, um recurso que ele teve que usar para poder dar conta de uma série de coisas. Eu acho que uma repressão só faz fortalecer e incentivar mais o uso porque se deparar com situações muito difíceis que eles não sabem como lidar e lidam usando drogas. Pesquisadora: Então formaria mais ou menos um círculo vicioso. E4: Vicioso. Quanto mais repressão, quanto mais violência, mais uso vai ter. Quanto mais pobreza, mais uso vai ter. Quanto menos possibilidades de uma vida razoável, mais uso de drogas vai ter. Pesquisadora: Então, talvez o fato do uso das drogas ser criminalizada, aliado ao fato de que o porte para uso é repreendido também com essa força, poderia até gerar um aumento na procura pela droga já que a gente pensou em ir contra valores. E4: Eu acho. Eu acho. Eu acho que tem que ter essa coisa criminal, eu acho que essas penas tem que ter para traficante $e$ não para usuário, para quem é dependente da droga. O dependente da droga precisa de tratamento e não de polícia”.

Entrevistado E4

“E5: Eu acredito mais na postura acolhedora. Porque a questão repressiva que aconteceu aqui em São Paulo, não é? Acho que já vai para quase 2 anos que aconteceu aquilo, é comprovado que não deu certo. Tanto que, recentemente, eu li uma reportagem na Folha de São Paulo que aquela casa que fica lá no centro, que eles faziam uso, já tem novamente os usuários de crack lá. Então, aquela forma repressiva que a prefeitura, enfim, a Secretaria Municipal de Saúde, Estadual usaram, foi comprovado que não funciona. Pelo contrário. Espalhou um monte de usuários para tudo quanto é bando da cidade. Até eles ofereceram, acho que a Secretaria Municipal de Saúde tentou oferecer algum tipo de atenção com os consultórios de rua, mas efetivamente não aconteceu. Então, assim, acho que parte a gente lida com motivação do usuário no tratamento. Por isso que é tão desafiante $[\ldots]$ ".

Entrevistado E5

E6:Já é difícil chegar neles. Se chegar com intuito de repressão não vai se conseguir oferecer o cuidado porque já ficam muito arredios. Eu acho que tem que tentar abordar por questões que talvez não sejam diretamente ligadas às 
drogas, mas que consiga criar um vínculo. Então, acho que o acolhimento é a melhor delas. Acho que a proposta do consultório de rua, de chegar até eles de alguma forma para, dali, abrir espaço para cuidado.

\section{Entrevistado E6}

E9: De acolhimento. Pesquisadora: E aí por que não o repressivo? Por que não dar um susto? E9: Porque daí talvez eu entraria com questões psicológicas, não é? Pesquisadora: Pode entrar. E9: Daí entraria em questões mesmo da conscientização, do quanto ele tem claro, do quanto ele já foi reprimido, ele já foi excluído. Uma pessoa que está numa condição de precariedade, morando nas ruas, fazendo uso do crack, que tem a diminuição da capacidade dele de volição, tem um efeito de uma droga química. Então ele tem uma questão química, tem essa dependência. Reprimir de uma condição de vida que talvez tenha levado ele a esse uso. Então, acho que reprimir não seria o caso. Tanto a gente sabe, que a internação compulsória não obteve um resultado, enfim, eficaz. Não foi uma intervenção eficaz.

\section{Entrevistado E9}

Pesquisadora: É. E ainda dentro desse contexto, você acha que uma primeira aproximação pela polícia, por exemplo, com viés eminentemente repressivo piora ainda mais... E10: Claro. Você está misturando tudo. Tratamento não é... Tratamento é uma coisa da saúde. Não da polícia. A polícia não dá tratamento. Quem dá tratamento são os profissionais da saúde. Quem tinha que ter chegado na Cracolândia não eram os policiais. Eram os profissionais da saúde. Quando chegam lá os policiais, você está reprimindo. Você não está tratando. Então foi tudo muito errado. Foi tudo muito torto. Então, é isso. Foi higienista. O que vem na minha cabeça toda essa coisa é a palavra 'higienização'. Então, você quer tirar as pessoas dali porque ficou feio e é muito doido. Você olha os bares, um monte de bêbado caindo na rua e isso não é feio. Agora, a Cracolândia é feio. E qual a porcentagem de bêbados batendo na esposa e qual a porcentagem de craqueiro batendo na rua, assim. É infinitamente menor, mas a gente tem que se preocupar com eles e não com os alcoolistas. É tudo muito louco. Pesquisadora: Você não acha que essa política criminal que mantém o usuário 
na condição de criminoso conversa com a política pública de reinserção social e tratamento? E10: Não. Não. Porque você está criminalizando alguém, você está colocando no mesmo lugar um criminoso e um doente. Não dá. Ou você olha ele como um criminoso ou você olha ele como um doente. Não dá para olhar como as duas coisas e querer dizer que você está tratando ele. Não dá.

Entrevistado E10

E11: Eu acho que o primeiro contato tem que ser um contato convidativo. Não repressor. Porque a repressão afasta. Ela não aproxima. Ela não é convidativa. Essas pessoas todas, o crack é sintoma. O uso do crack é um sintoma. Não é uma causa. Essas pessoas precisam de acolhimento. Precisam de cuidado. Quando você chega lá numa política repressora, essas pessoas não se sentem nem um pouco a estar juntas ali, a pensar na possibilidade de se aproximar de algum lugar de cuidado. Pelo contrário, elas ficam completamente ansiosas

\section{Entrevistado E11}

E12: Repressão não adianta nada, punição não adianta nada, não motiva ninguém a tratar. E o acolhimento, por outro lado, pode de alguma forma motivar essa pessoa a um determinado momento poder se tratar. Pode ser que não também, mas se tem alguma possibilidade maior é pelo acolhimento. Assim, já ouvi, isso é uma questão supercomplexa porque, assim, já ouvi relatos de jornal, coisa assim, que: "Ah, se não tivessem me levado à força naquela época eu estava no fundo do poço agora.". Essa não é a minha abordagem nem da maioria das pessoas que eu trabalho, então eu não tenho essa amostra. Minha amostra é uma amostra que volta quando você acolhe.

\section{Entrevistado E12}

E13: [...] a repressão eu acho que não motiva ninguém a buscar tratamento, acho que ter passagem pela polícia, ter sido preso, ter tido contato com polícia, ter sido pego na blitz da Lei Seca, acho que nada disso motiva ninguém a buscar tratamento, pelo menos eu nunca vi ninguém que buscou tratamento por esses motivos. 
E15: Seguramente, eles veem o Estado como um elemento de punição, de agressão, de violência e não de cuidado.

\title{
Entrevistado E15
}

E16: Acolhedor, com certeza. Acho que não tem nem como justificar, é uma questão óbvia essa. A parte repressiva muitas vezes afastava o usuário do serviço. Tive uma outra experiência, de tratamento fechado, de internação para dependentes químicos, tivemos um problema, a polícia quis entrar à força para reconhecer um paciente e a gente dizer que não poderia e mesmo assim entrou e ficou um clima bem difícil, mesmo depois de tudo, do pessoal ter ido embora, deu para perceber que os pacientes ficaram um pouco mais com o pé atrás com toda a equipe.

\section{Entrevistado E16}

Como se observa dos trechos citados, a experiência traumática propiciada pelas experiências com as agências repressivas do Estado incita o medo e reforça o estigma negativo que pesa sobre os usuários de drogas. Como bem afirmou um dos entrevistados, "veem o Estado como um elemento de punição, de agressão, de violência e não de cuidado", o que já tinha sido constatado pelos pesquisadores da Cracolândia, como citado acima.

Essa sensação do medo causado pela atividade repressiva, embora tenha sido atrelada somente à ameaça da detenção, um erro, é sentida também pelos doutrinadores penais. A contradição ainda existe, vejamos:

\begin{abstract}
Obviamente o dependente ficaria no mínimo desconfiado de alguns tratamentos, como receber seringa do Estado ao se declarar dependente, sabendo que o mesmo Estado poderia aplicar-lhe uma pena de detenção justamente pelo fato de se declarar dependente. Seria uma grande contradição, felizmente evitada pelo legislador. 223
\end{abstract}

Deve-se, no entanto, ressaltar que quando abertamente questionados sobre o medo que sentiam dos agentes do Estado, poucos dos usuários disseram ter deixado de procurar

${ }^{223}$ GUIMARÃES, Marcelo Ovídio Lopes (Org.). Nova Lei Antidrogas Comentada - Lei n $\mathbf{n}^{\mathbf{0}}$ 11.343/06. São Paulo: Quartier Latin, 2007, p. 40. 
tratamento por este motivo, sendo um movimento percebido apenas indiretamente, pelos profissionais, mas não consciente e relatada pelos usuários. A maioria dos usuários atrela a busca pelo tratamento à conscientizações ocorridas nos momentos de abstinência, deixando absolutamente claro que, durante o uso - entendido como o memento mesmo de administração da droga -, não pensam em se tratar, não é possível pensar em se tratar.

Além do descrito receio de buscar ajuda, aos olhos dos agentes oficiais, os usuários se percebem apenas como drogados e criminosos. Essa caracterização negativa é ainda reforçada, no que tange aos usuários de crack, pela constante divulgação midiática sobre sua natureza: são zumbis, agressivos, o mal a ser combatido. Perdem sua individualidade para serem taxados em decorrência da substancia que consomem. Segundo as entrevistas realizadas com a equipe multidisciplinar, é bastante comum que os usuários se identifiquem apenas pela droga que usam.

As implicações decorrentes da atribuição do rótulo pejorativo e da interação do sujeito com a qualidade a si atribuída já foi explicada no capítulo anterior. Em suma, experiências traumáticas - ou cerimônias degradantes, como denominou Garfinkel ${ }^{224}$ reconstroem a identidade do sujeito, condicionando negativamente suas ações posteriores na interação com os outros. O sujeito se comporta como acredita que os outros esperam que ele se comporte, o que, no caso do drogado, significa usar drogas e, no caso do criminoso, cometer crimes.

Essa realidade dos agentes públicos de saúde não se aplicaria, no entanto, àqueles usuários que desenvolvem o consumo em ambientes protegidos, uma vez que o agente de saúde não bate na porta da casadas pessoas oferecendo tratamento. Com relação a esses indivíduos, no entanto, o que pesa é a diferença entre o status de desacreditado e desacreditável explorado por Goffman ${ }^{225}$ e também já abordado no capítulo imediatamente anterior. Se o sinal negativo é desconhecido, a preocupação do sujeito transmuta-se para a vigilância acerca da manutenção do desconhecimento alheio sobre essa condição negativa.

224 GARFINKEL, Harold. Conditions of Successful Degradation Ceremonies. American Journal of Sociology, v.61, n.5, pp.420-424, mar. 1956. The University of Chicago Press. Disponível em: <http://www.jstor.org/stable/2773484>. Acesso em: 20 dez. 2013.

225 GOFFMAN, Erving. Estigma: notas sobre a manipulação da identidade deteriorada. $4^{\mathrm{a}}$ ed. Rio de Janeiro: LTC, 1988, p. 38. 
Caso contrário, seria despojado publicamente de sua identidade para tornar-se, como divulga a grande mídia, "a escória da população", "o grande problema da atualidade”. Sua individualidade seria reconstruída tendo como característica principal o rótulo consequente do ato desviado, pelo que, justifica-se o esforço em manter oculto o estigma já existente, para evitar maiores proporções.

\footnotetext{
(...) quando a diferença não está imediatamente aparente e não se tem dela um conhecimento prévio (ou, pelo menos, ela não sabe que os outros a conhecem), quando, na verdade, ela é uma pessoa desacreditável, e não desacreditada, nesse momento é que aparece a segunda possibilidade fundamental em sua vida. A questão que se coloca não é a da manipulação da tensão gerada durante os contatos sociais e, sim, da manipulação de informação sobre o seu defeito. Exibi-lo ou ocultá-lo; conta-lo ou não conta-lo; revela-lo ou escondê-lo; mentir ou não mentir; $\mathrm{e}$, em cada caso, pra quem, como, quando e onde..$^{226}$
}

Como consequência dessa tensão em ocultar o rótulo, podemos pensar a dificuldade dos usuários em procurar o serviço de saúde, tanto pela relação com a droga, de forma direta, quanto por problemas decorrentes desse uso, em virtude do medo da divulgação da sua condição que, aliada ao imenso preconceito do senso comum em relação ao seu problema, tornariam a sua vida ainda mais problemática. Esse medo do preconceito, inclusive dos profissionais de saúde, foi relatado em algumas entrevistas:

"Pesquisadora: E você acha que têm alguns fatores que não impedem, mas que funcionam como uma espécie de bloqueio para a pessoa procurar o tratamento? Pensando na primeira vez que a pessoa vai procurar. E13: Acho. Eu acho que tem uma questão do estigma associado ao uso de drogas. Eu acho que isso é o mais importante para a pessoa não chegar ao tratamento, acho que a pessoa não reconhecer que é um problema ou ter vergonha de procurar ajuda por isso. Ter medo de como vai ser tratado, ter medo de como vai ser a receptividade dos profissionais. Bom, não sei se cabe, mas eu vou continuar falando, foi bem interessante hoje, eu atendi um paciente no A. C. Camargo que aconteceu uma coisa muito grave com ele, ele caiu no sábado, bateu a cabeça, e aí domingo ele acordou e começou a ter uma alteração de comportamento. É muito grave e foi

${ }^{226}$ GOFFMAN, Erving. Estigma: notas sobre a manipulação da identidade deteriorada. $4^{\mathrm{a}}$ ed. Rio de Janeiro: LTC, 1988, p.38. 
muito agudo, ele bateu a cabeça sábado à noite e domingo de manhã ele estava bizarramente esquisito. E aí ele foi ao Pronto Socorro do hospital hoje e a plantonista falou: "Não, isso é porque ele bebe.". Eu falei: "Não, isso não é porque ele bebe. Ele vai voltar lá agora, eu vou fazer uma carta, porque isso é muito grave. Ele pode estar com sangramento no cérebro, ele pode estar com um milhão de coisas acontecendo.”. E aí a esposa dele começou a chorar e falou: "Eu senti que houve um preconceito da médica quando eu falei que ele fazia tratamento para bebida”. Então essa é a reação normal dos profissionais de saúde em geral. Então o paciente acha que é isso que ele vai encontrar num lugar específico para dependência. Ele não sabe que num lugar específico para dependência as pessoas vão estar treinadas para lidar com isso, acostumadas a lidar com isso, então é muito difícil vencer esse preconceito que eles esperam encontrar, é o preconceito com o qual eles têm que lidar no dia a dia deles." (g.n)

\section{Entrevistado E13}

Além do serviço de saúde, ser pego pela polícia, por exemplo, pode tornar pública a sua condição à medida que "os usuários levados ao JECrim, continuam recebendo 'informação desabonadora constante em registros de antecedentes' até o cumprimento integral da medida imposta pelo juiz. Essa anotação, mesmo que temporária, traz consequências desagradáveis, principalmente quando se busca estabelecer vínculos de trabalho formal, como a carteira assinada"227.

Diante dessas constatações, parece razoável concluir que o desenvolvimento de uma política de saúde séria, que objetive a atenção e reinserção social dos usuários de drogas realmente esbarra na manutenção da criminalização de sua conduta, que viabiliza o contato repressivo entre os agentes do Estado e esses indivíduos. Aliás, essa incoerência justificaria até as confusões dos discursos oficiais, uma vez que encarar o uso de drogas como um problema de saúde e social implica em retirá-lo, de vez, do rol das infrações penais, porque

\footnotetext{
${ }^{227}$ GRILLO, Carolina Christoph; POLICARPO, Frederico; VERISSIMO, Marcos. A "dura" e o "desenrolo": efeitos práticos da nova lei de drogas no Rio de Janeiro. Rev. Sociol. Polit. - online, v.19, n.40, pp. 135148, 2011, p. 139.
} 
as ações direcionadas a uma pessoa que precisa de auxílio de profissionais especializados não pode, nem deve, ser tratado como uma criminosa.

Poder-se-ia, no entanto, em contraposição a esse pensamento, argumentar no sentido de que a disposição legal que criminaliza usuário não se esgota na ação da polícia e, com o abandono da pena de prisão como resposta ao fenômeno, tem como última consequência a aplicação de medidas com caráter educativo e ressocializador que seriam adequadas a propiciar a reflexão necessária para que o indivíduo fortalecesse os laços sociais e repensasse sua relação com as drogas. O raciocínio é válido e merece ser enfrentado.

De fato, a lei prevê, após o regular procedimento penal, a aplicação de medidas alternativas à prisão, que poderiam, se bem utilizadas, diminuir a ineficácia da norma. Ocorre que segundo os usuários, muito obstante não fiquem à vontade para falar dessas experiências, quando abordados, os policiais raramente os levam para a delegacia, para a elaboração do termo circunstanciado e consequente aplicação das medidas previstas em lei. Na prática, portanto, o que prevalece é apenas o contato violento e repressivo da polícia, que provoca os efeitos negativos já descritos.

“Pesquisadora: Eles não levaram para a delegacia? P3: Não. Não. Não. Se você tiver dinheiro no bolso eles tomam. Pesquisadora: Aí eles não te levam? P3: Não. Então quando eu vou na boca, geralmente eu vou com $R \$ 100, R \$ 150$ a mais. Geralmente eu gasto $R \$ 100,00$ quando eu vou. Porque eu não uso direto, todo dia, não é? Então eu uso recreativo. Então eu me programo. A cada 15 dias eu vou pegar e aí eu pego uma quantidade legal. Mas sempre levo um dinheiro a mais, caso eu seja abordado, porque se tiver dinheiro no bolso eles levam. Mas já aconteceu de um colega meu, o cara pegar, virar o pacote de cocaína, jogar no chão e mandar o cara cheirar; da Polícia Militar. Pesquisadora: Então não dá nada? Usar não dá nada? P3: Não. Usar não. Você traficar dá. Você roda. Se você quiser ter os olhos grandes, ser um vicioso, aí tem problema". 
"Pesquisadora: Eles costumam levar para a Delegacia ou eles fazem esculacho na rua? P7: Esculacha, bate e deixa lá. Pesquisadora: Não fazem nada? P7: Nada. Pesquisadora: Para a Delegacia nunca te levaram? P7: Nunca. Mas bater, eles me bateram muito. Eu tenho hematomas, vários hematomas”.

\section{Entrevistado P7}

“Pesquisadora: E a Polícia costuma levar para a Delegacia depois que faz a abordagem ou só esculacha e vai embora? P8: Não, bate e me manda embora. Pesquisadora: Não faz nada? Não leva para a Delegacia? Não faz o procedimento...P8: Nunca fui para a Delegacia. Pesquisadora: Mas já foi enquadrado várias vezes? P8: Já. Pesquisadora: E alguma vez... P8: Já roubaram dinheiro meu... Diversas vezes, né? Pesquisadora: Eles pegam o dinheiro? P8: Levam dinheiro, além de bater, levam dinheiro. Pesquisadora: E geralmente eles falam o quê? P8: Te xingam de tudo quanto é nomes. Te batem. Te agridem psicologicamente de todas as formas possíveis. Chegou uma vez, um policial ameaçou a fazer roleta-russa comigo. Sabe? Ele virou... Pesquisadora: E por quê? Qual era a situação? P8: Por prazer sádico de maltratar um outro ser humano. Pesquisadora: Ele te encontrou em que situação? P8: Em uma favela. Eu nem tava com droga nesse dia. Só que logicamente que ele sabia que eu estava indo buscar a droga. Ele tomou meu dinheiro, me bateu; me ameaçou com o revólver. Colocou uma bala só no tambor revolver, ele girou e falou: "Agora a gente vai fazer uma brincadeira com você", né? Então... E outras vezes, muitas vezes".

\section{Entrevistado P8}

“Pesquisadora: Entendi. (...), você já teve alguma experiência com a polícia? P9: Nunca tive. Pesquisadora: Nunca levou um enquadro? P9: Não. Pesquisadora: Eles nunca chegaram perto de você? P9: Não. Pesquisadora: E nos dias em que você ficou na rua, você chegou a ver a polícia por ali? Enquadrando alguém? P9: Já vi já. Pesquisadora: E como que foi isso? Como você viu? Eles são gentis? Não são gentis? P9: Teve várias vezes. Já vi várias vezes, inclusive, até, eu assim, na boca mesmo eles me deixarem de lado e irem para cima dos traficantes. Pesquisadora: O usuário não interessa muito para 
eles. P9: Isso. Não interessa. Eu vi que eles não interessam muito. E vai embora. Sabe? "Vai embora daqui". Pesquisadora: Eles mandam embora. P9: Eles mandam embora. Sabe? E os outros, falaram: "Vai lá para trás". Pesquisadora: Entendi. P9: Aí no outro dia ficar sabendo que aquelas pessoas, uns foram presos, outros apanharam. Pesquisadora: Mas só traficante? P9: Só aquele pessoal sem ser usuário”.

\section{Entrevistado P9}

"Pesquisadora: Fora essa experiência que você teve com a polícia, por causa da sua mãe. Você já teve alguma outra experiência com a polícia por causa da droga? Já tomou enquadro? P11: Ah vários. Vários. Várias vezes já me enquadraram, já pegaram a minha droga. A Guarda Civil Metropolitana. São Caetano. Várias vezes já pegou minha droga. Uns jogam fora, outros cheiram na minha frente. Por exemplo, cocaína. Já me pegaram várias vezes com cocaína, guarda civil. Colocavam no carro mesmo e falavam: "Olha, (...). Que legal”. Cheiravam na minha frente. Outros jogavam fora. Pesquisadora: Mas não costumam levar para a delegacia? P11: Nunca me levaram para a delegacia porque eu sempre falei a verdade: "Você é usuária?” Sou. "O que você usa?” Tudo. “O que você tem aí?” Está aqui. Está aqui. Quer levar? Leva. Porque para conseguir droga é fácil. Pode levar. Daqui a meia hora eu tenho de novo. Pesquisadora:Então, eles nem se interessam pelo usuário? O usuário eles não levam para a delegacia? P11:Usuário eles não levam. Eu, pelo menos, nunca fui para a delegacia por estar fumando, nada”.

\section{Entrevistado P11}

Essa realidade já havia sido descrita num estudo realizado na cidade do Rio de Janeiro entre novembro de 2007 e julho de 2009 a fim de analisar o impacto da Lei $\mathrm{n}^{\text {o }}$ $11.343 / 06$ na relação entre o sistema de justiça criminal e os usuários de drogas 228.

\footnotetext{
${ }^{228}$ GRILLO, Carolina Christoph; POLICARPO, Frederico; VERISSIMO, Marcos. A "dura" e o "desenrolo": efeitos práticos da nova lei de drogas no Rio de Janeiro. Rev. Sociol. Polit. - online, vol.19, n.40, pp. 135$148,2011$.
} 
Os pesquisadores realizaram entrevistas com juízes, promotores e defensores públicos atuantes nos Juizados Especiais Criminais e constataram que, com a alteração legislativa que excluiu a prisão do rol de penas passíveis de serem aplicadas aos usuários que portam drogas para o seu consumo, eles passaram a sentir-se desobrigados de atuar com relação ao crime por uso de drogas, pois percebiam essa infração como fora da competência da Justiça Criminal. Ademais, alegavam que que a ausência de possibilidade de aplicação da pena privativa de liberdade teria eliminado as garantias de cumprimento das medidas determinadas em juízo ${ }^{229}$.

Essa postura é reforçada pelo posicionamento da doutrina, que, como já se afirmou, permanece fazendo afirmações no sentido de que o usuário de drogas "perdeu a pecha de criminoso" ou "foi excluído do sistema de justiça criminal".

Analisando o número de ocorrências por porte de drogas para consumo pessoal no Rio de Janeiro, a pesquisa constatou que os flagrantes por essa infração penal caíram cerca de $20 \%$ após a entrada em vigor da Lei $\mathrm{n}^{\mathrm{o}} 11.343 / 06^{230}$, mesmo que o diploma legal tenha mantido a obrigatoriedade de que os usuários, surpreendidos portanto drogas para seu consumo, sejam encaminhados à delegacia de polícia para elaboração do Termo Circunstanciado. Afirmam os pesquisadores que:

\begin{abstract}
A redução do processamento legal de casos de uso de drogas levou-nos a supor que a administração dos mesmos teria ficado sob a responsabilidade da Polícia Militar, instituição que realiza o policiamento ostensivo, atuando na ponta do sistema de justiça criminal. $\mathrm{O}$ aparente descaso do poder Judiciário com a redução da entrada de usuários no sistema parece ter legitimado a atuação informal dos policiais militares que, já desde antes da nova lei, negociavam o encaminhamento, ou não, dos indivíduos flagrados para a delegacia ${ }^{231}$.
\end{abstract}

Essa suposição restou fortalecida pela declaração de um policial durante a pesquisa de campo realizada numa delegacia que, apesar de situada num bairro considerado pela própria organização policial como de classe média baixa, não realizava muitos flagrantes do tipo:

${ }^{229}$ GRILLO, Carolina Christoph; POLICARPO, Frederico; VERISSIMO, Marcos. A "dura" e o "desenrolo": efeitos práticos da nova lei de drogas no Rio de Janeiro. Rev. Sociol. Polit. - online, vol.19, n.40, pp. 135148, 2011, p. 136.

${ }^{230}$ Em São Paulo não foi possível a obtenção desse dado, uma vez que a Secretaria de Segurança Pública de São Paulo, por meio de seu site oficial, só divulga o número de ocorrências anuais de tráfico de drogas, não disponibilizando dados sobre flagrantes de porte para uso pessoal.

${ }^{231}$ GRILLO, Carolina Christoph; POLICARPO, Frederico; VERISSIMO, Marcos. Op. Cit., p. 137. 


\begin{abstract}
Delegados e policiais confirmaram a nossa percepção de que esses casos não eram muito comuns naquela distrital, estando a atenção das investigações e a cobrança sobre a atuação da Polícia Militar (PM) voltadas para o combate ao roubo de carro e ao roubo a transeunte. Quando revelamos o intuito de acompanhar o registro de algum flagrante de drogas, um dos plantonistas ofereceu-se: 'Se vocês quiserem eu posso ir lá fora buscar um para vocês verem'. A fala desse policial denota que eles sabem muito bem onde e como capturar e trazer para a delegacia consumidores de substâncias proibidas, no entanto, essa não é uma das suas prioridades naquela área ${ }^{232}$.
\end{abstract}

Muito embora os relatos de corrupção policial antecedam a entrada em vigor da Lei $\mathrm{n}^{\circ} 11.343 / 06$, o fato é que a exclusão da pena de prisão como possibilidade para apenar o usuário gerou uma descrença generalizada nos operadores do sistema, desde os policiais até os juízes criminais. O que mudou, portanto, “foi o aval implícito do poder Judiciário para que esse tipo de negociação transcorra, na medida em que o processamento legal desses casos perdeu importância, mas o crime continuou existindo"233.

Esse excesso de poder relegado aos policiais já havia ficado claro quando da análise das pesquisas realizadas pela Universidade Candido Mendes ${ }^{234}$ e pelo Núcleo de Estudos de Violência da USP ${ }^{235}$. São os policiais militares que decidem quais casos encaminhar ao poder judiciário, bem como sob qual tipo penal. Essa discricionariedade permite que os policiais ameacem os usuários com eventual imputação por tráfico de drogas, haja vista a ausência de critérios objetivos fixados pela lei para diferenciação entre as condutas.

Como já mencionado acima, na cidade do Rio de Janeiro, as ocorrências por porte de drogas para uso pessoal caíram cerca de $20 \%$ desde a entrada em vigor da Nova Lei de Drogas, em 2006. No entanto, uma comparação entre as somas dos 24 meses anteriores e os posteriores à entrada em vigor da nova lei de drogas revelou que os totais de incidência para tráfico cresceram $8,2 \%$, o que incita o questionamento sobre se as ocorrências, antes

\footnotetext{
${ }^{232}$ GRILLO, Carolina Christoph; POLICARPO, Frederico; VERISSIMO, Marcos. A "dura" e o "desenrolo": efeitos práticos da nova lei de drogas no Rio de Janeiro. Rev. Sociol. Polit. - online, vol.19, n.40, pp. 135148, 2011, p. 137.

${ }^{233}$ Ibidem, p. 137.

${ }^{234}$ CRESPO, Aderlan (Coord.). Critérios judiciais determinantes do consumo e do tráfico. Rio de Janeiro: Universidade Candido Mendes, Núcleo de Iniciação Científica - NIC/UCAM, 2011.

${ }^{235}$ JESUS, Maria Gorete Marques. (Org.). Prisão Provisória e Lei de Drogas: estudo sobre os flagrantes de tráfico de drogas na cidade de São Paulo. Núcleo de Estudos da Violência (NEV-USP), 2011. Disponível em: 〈http://www.nevusp.org/downloads/down254.pdf>. Acesso em: 25 dez. 2013.
} 
tipificadas como porte para uso, não estão sendo transformadas em tráfico ${ }^{236}$, ou pelo poder de barganha do indivíduo flagrado, ou pelas características socioeconômicas que fazem presumir quem seria o vendedor e quem seria o comprador.

Por fim, para viabilizar a conclusão, nenhum dos usuários entrevistados, quando questionados acerca dos motivos determinantes para a busca de ajuda, mencionou o status de ilegalidade da substância consumida ou as experiências com a repressão penal como ensejadores de reflexão para a procura de tratamento.

${ }^{236}$ GRILLO, Carolina Christoph; POLICARPO, Frederico; VERISSIMO, Marcos. A "dura" e o "desenrolo": efeitos práticos da nova lei de drogas no Rio de Janeiro. Rev. Sociol. Polit. - online, vol.19, n.40, pp. 135148, 2011. 


\title{
Conclusão
}

\begin{abstract}
A constatação de que a solução punitiva sempre importa num grau considerável de violência, ou seja, de irracionalidade, além da limitação de seu uso, impõe-se, na hipótese em que se deva lançar mão dela, a redução, ao mínimo, de sua irracionalidade. ${ }^{237}$
\end{abstract}

De todo o exposto, podemos concluir que muito embora a promulgação da Lei $n^{\circ}$ 11.343/06 tenha significado um avanço teórico no tratamento jurídico criminal da questão das drogas, principalmente no que se refere às condutas associadas ao uso dessas substâncias, o caminho, por certo, ainda não se encerrou.

A prática judiciária, por seus operadores, permanece vinculada, na maior parte dos casos, à mentalidade eminentemente repressiva que vigorava como única até o advento da nova Lei, inviabilizando que os avanços operados pelo texto da norma sejam operacionalizados.

A não aplicação da pena de prisão por uma disposição processual foi um avanço, seu reconhecimento, pelo texto de lei, como resposta inadequada às condutas empreendidas pelo usuário de drogas, um avanço ainda maior, mas não se pode esquecer que esse cidadão, que sofre de um problema de ordem médica, ainda passa pelo estigmatizante sistema de justiça criminal e é objeto da violenta repressão policial. Tudo isso porque o porte de drogas para consumo pessoal permanece sendo crime.

Como se depreendeu da análise das entrevistas, aliado ao fato de que os relatos da abordagem policial são sempre negativos, não há casos em que os pacientes informem terem sido levados à delegacia de polícia para que fosse dada continuidade ao procedimento penal adequado para apuração do porte de drogas para o consumo pessoal, qual seja, a lavratura do competente termo circunstanciado e posterior encaminhamento ao Juizado Especial Criminal para aplicação das medidas alternativas à prisão fixadas no artigo 28 da Lei n $^{\circ}$ 11.343/06.

${ }^{237}$ PIERANGELI, José Henrique; ZAFFARONI, Eugênio Raul. Manual de Direito Penal Brasileiro. v.1: Parte Geral. 8 ed. São Paulo: Revista dos Tribunais, 2010. p. 35. 
Não obstante a maioria acadêmica, das várias áreas do conhecimento que tocam o tema, já se manifeste pela ineficácia do modelo repressivo em defesa de uma abordagem humana que priorize o tratamento do usuário de drogas, ainda vigoram discursos políticos carregados de preconceito e ações paliativas de combate violento e ineficaz ao uso dessas substâncias e, porque não dizer, ao próprio usuário.

Se a saúde é o ponto fundamental, que assim seja, realmente. Que as abordagens sejam efetuadas por profissionais capacitados para a construção ou retomada dos vínculos necessários para que o indivíduo, se assim desejar, deixe de usar drogas. O abandono da pena de prisão não pode ser substituído, por exemplo, pelo encarceramento velado das internações compulsórias. Destituído o cidadão dos direitos fundamentais garantidos ao sujeito do processo penal, por ordem de um magistrado a privação de liberdade se efetiva sob outra denominação. Abandona-se a pena, adota-se o tratamento. A realidade, entretanto, efetivamente se transforma?

A criminalização tanto do tráfico, quando do uso é, por enquanto, a opção legislativa do nosso país. Como já se afirmou no decorrer desse texto, concordemos ou não, alheios às críticas, os tipos penais relativos às drogas permanecem válidos em nosso ordenamento jurídico até que alguma decisão judicial lhes tome a validade ou que o diploma legal seja substituído. Não basta que os discursos dos porta vozes oficiais do Estado afirmem que o usuário não é mais um problema de polícia para que a realidade se transforme. Na prática, a teoria tem sido outra.

Talvez os próprios envolvidos com a política de drogas sejam, no discurso, traídos pela ideia inconsciente de que é impossível objetivar a atenção e reinserção social dos indivíduos por meio de um diploma legal que permanece tratando-os como criminosos. Antes a consciência inconsciente, do que imaginar um discurso intencionalmente projetado para distorcer a realidade da política vigente no nosso país. Abandonar, mesmo que apenas no que toca ao usuário, a política repressiva, é ato político de coragem e, com certeza, sujeito a críticas severas da população que vota. Politicamente, talvez não seja um bom negócio.

O que se espera é que o poder público seja fiel às opções que fez. Se se rechaça a privação de liberdade, que não a efetive sob outra denominação. Se acata a 
multidisciplinariedade do fenômeno das drogas, que dê espaço e ouvidos aos profissionais envolvidos no estudo do tema. Se entende o usuário como problema de saúde e não como um fenômeno de ordem criminal, que descriminalize a sua conduta. Que se dispa do preconceito e incite o diálogo. Que, no diálogo, possa aceitar alternativas, mesmo que contrárias à mentalidade dominante.

E, por fim, que o Direito Penal não sirva para a defesa de valores morais, restringindo sua atuação somente às situações que demandem sua resposta violenta. 


\section{REFERÊNCIAS}

ADORNO, Rubens de Camargo Ferreira. Autoridades divergem sobre como tratar usuários de crack. São Paulo, 2010. Disponível em:

<http://www.band.com.br/jornalismo/saude/conteudo.asp?ID=302755>. Acesso em: 14 de janeiro de 2014.

AMBOS, Kai. Control de drogas: política y legislación em América Latina, EE.UU. Y Europa : eficacia y alternativas. Santa Fé: Juridicas Gustavo Ibañez, 1998. 466 p.

ASSOCIACAO BRASILEIRA DE PSIQUIATRIA. Abuso e dependência: crack. Rev. Assoc. Med. Bras. - online, v.58, n.2, pp. 138-140, 2012.

BARATTA, Alessandro. Criminologia Crítica e Crítica do Direito Penal. 3 ed. Revam, 2003.

BECKER, Howard. Outsiders: estudos de sociologia do desvio. Rio de Janeiro: Jorge Zahar, 2008.

BOITEUX, Luciana. Breves considerações sobre a política de drogas brasileira atual e as possibilidades de descriminalização. Boletim IBCCRIM, São Paulo, v.18, n.217, p.16, dez. 2010.

BOSCHI, José Antonio Paganella. A nova lei antitóxicos: primeiras impressões. In: FAYET JÚNIOR, Ney. Ensaios penais em homenagem ao Professor Alberto Rufino Rodrigues de Sousa. Porto Alegre: Ricardo Lenz, 2003, p.389-419.

BOSCHI, José Antonio Paganella. A nova lei antitóxicos: primeiras impressões. Revista da ESMESC: Escola Superior da Magistratura do Estado de Santa Catarina, Florianópolis, v.8, n.14, p.121-145, 2002.

BRASIL. Supremo Tribunal Federal. Acompanhamento processual. Recurso Extraordinário $\quad \mathbf{n}^{\mathbf{0}} \quad \mathbf{6 3 5 . 6 5 9}$ Disponível em: <http://www.stf.jus.br/portal/processo/verProcessoAndamento.asp?incidente=4034145>. Acesso em: 31 jan. 2013. 
BRASIL. Decreto $\mathbf{n}^{\mathbf{0}} \mathbf{2 0 . 9 3 0 / 3 2}$. Fiscaliza o emprego e o comércio das substâncias tóxicas entorpecentes, regula a sua entrada no país de acordo com a solicitação do Comité Central Permanente do Ópio da Liga das Nações, e estabelece penas. Disponível em: http://www2.camara.leg.br/legin/fed/decret/1930-1939/decreto-20930-11-janeiro-1932498374-publicacaooriginal-81616-pe.html, acessado em 14 de janeiro de 2014.

BRASIL. Lei $\mathbf{n}^{\mathbf{0}}$ 6368/76. Dispõe sobre medidas de prevenção e repressão ao tráfico ilícito e uso indevido de substâncias entorpecentes ou que determinem dependência física ou psíquica, e dá outras providências. Disponível em: http://www.planalto.gov.br/ccivil_03/leis/16368.htm, acessado em 14 de janeiro de 2014.

BRASIL. Lei n⿳0 9.099/95. Dispõe sobre os Juizados Especiais Cíveis e Criminais e dá outras providências. Disponível em: <http://www.planalto.gov.br/ccivil_03/leis/19099.htm>. Acesso em: 05 jan. 2014.

BRASIL. Lei $\mathbf{n}^{\mathbf{0}} \mathbf{1 0 . 2 5 9}$ /01. Dispõe sobre a instituição dos Juizados Especiais Cíveis e Criminais no âmbito da Justiça Federal. Disponível em: <http://www.planalto.gov.br/ccivil_03/leis/leis_2001/110259.htm>. Acesso em: 05 jan. 2014.

BRASIL. Lei no 11.343/06. Institui o Sistema Nacional de Políticas Públicas sobre Drogas - Sisnad; prescreve medidas para prevenção do uso indevido, atenção e reinserção social de usuários e dependentes de drogas; estabelece normas para repressão à produção não autorizada e ao tráfico ilícito de drogas; define crimes e dá outras providências. Disponível em http://www.planalto.gov.br/ccivil_03/_ato2004-2006/2006/lei/111343.htm, acessado em 14 de janeiro de 2014.

BRASIL. Supremo Tribunal Federal. Acompanhamento processual. Recurso Extraordinário RE 430.105/RJ. Disponível em: <http://www.stf.jus.br/portal/processo/verProcessoAndamento.asp?incidente=2228314. Acesso em:10 jan. 2012.

CAllegari, André Luiz. Lei de Drogas - Aspectos Polêmicos. À luz da Dogmática Penal e da Política Criminal. 1 ed. São Paulo: Livraria do Advogado, 2008.

CAPEZ, Fernando. A Nova Lei de Tóxicos: Modificações Legais Relativas à Figura do Usuário. Revista Magister de Direito Penal e Processual Penal. São Paulo, ano III, num. 14, p. 66-72, out-nov/2006. 
CARLINI, E.A. et al. I Levantamento domiciliar nacional sobre uso de drogas psicotrópicas no Brasil (2001). São Paulo: Secretaria Nacional Antidrogas/Centro Brasileiro de Informações sobre Drogas Psicotrópicas, 2002.

II Levantamento domiciliar sobre o uso de drogas psicotrópicas no Brasil: estudo envolvendo as 108 maiores cidades do Brasil, 2005. São Paulo: Centro Brasileiro de Informações sobre Drogas Psicotrópicas/ Secretaria Nacional Antidrogas; 2007.

CARVAlHO, Salo. A Política Criminal de Drogas no Brasil: Estudo criminológico e dogmático da Lei no 11.343/06. 6 ed. São Paulo: Saraiva, 2013.

CARVALHO, Fernando Varela. et al. Drogas, por três penas. Aspectos farmacológicos, educacionais e comunitários, v.1, 2 ed., Coleção Argo, São Paulo, 1998.

CARVALHO, Heraclito Barbosa; SEIBEL, Sergio Dario. Crack cocaine use and its relationship with violence and HIV. Clinics - online, vol.64, n.9, pp. 857-866, 2009.

CAVALIERI, Ana Lúcia Ferreira. EGYPTO, Antonio Carlos. Drogas e Prevenção: A cena da Reflexão. 4 ed. São Paulo: Saraiva, 2004.

CENTRO BRASILEIRO DE INFORMAÇÕES SOBRE DROGAS PSICOTRÓPICAS CEBRID. Secretaria Nacional Antidrogas. Gabinete de Segurança Institucional. Jogo de folhetos explicativos sobre drogas psicotrópicas. São Paulo, s.d.

CHAVES, Tharcila V. et al. Fissura por crack: comportamentos e estratégias de controle de usuários e ex-usuários. Rev. Saúde Pública - online, v.45, n.6, pp.1168-1175. Epub: 02 sep. 2011.

A vivência da fissura por crack: rebaixamento de valores e estratégias utilizadas para o controle - Living with cravings for crack: lowering of values and control strategies used. São Paulo: s.n, 2009 - 127. Dissertação (Mestrado em Psicobiologia). Universidade Federal de São Paulo. Escola Paulista de Medicina. (UNIFESP - Biblioteca Central).

CHIZOTTI, Antonio. Pesquisa qualitativa em ciências humanas e sociais. 4 ed. Petrópolis: Editora Vozes, 2011.

COSTA, Álvaro Mayrink. Raízes da sociedade criminógena. 2.ed. Rio de Janeiro: Lumen Juris, 2010. 444 p. 
CRESPO, Aderlan (Coord.). Critérios judiciais determinantes do consumo e do tráfico. Rio de Janeiro: Universidade Candido Mendes, Núcleo de Iniciação Científica NIC/UCAM, 2011.

CROCE, Delton; CROCE JR., Delton. Manual de Medicina Legal. 7 ed. São Paulo: Saraiva, 2010.

CRUZ, Marcelo Santos; VARGENS, Renata Werneck; RAMÕA, Marise de Leão. Integração de Competências no Desempenho da Atividade Judiciária com Usuários e Dependentes de Drogas. Ministério da Justiça. Secretaria Nacional de Políticas sobre Drogas, MPO, Eduardo Roberto Alcântara. Medicina Legal. Material Didático.

DEL OMO, Rosa. A face oculta da droga. Rio de Janeiro: Revan, 2009. 86 p.

. A América Latina e sua Criminologia. 1 ed. Rio de Janeiro: Revam, 2004.

. (Comp.). Estigmatizacion y conducta desviada. Maracaibo: Universidad del Zulia, 1973.

DENARC. Caminho sem Volta. Livreto educativo. DENARC/DIPE. São Paulo, 2009.

DIAS, Jorge de Figueiredo; ANDRADE, Manuel da Costa. Criminologia: o homem delinquente e a sociedade criminógena. 2.reimp. Coimbra: Coimbra Editora, 1997

ECO, Humberto. Como se faz uma tese. São Paulo: Editora Perspectiva, 2010.

FERRI, Cleusa Pinheiro. Cocaína: padräo de consumo e fatores associados à procura de tratamento. - Cocaine: users and associated factors with treatment-seeking behaviour. Säo Paulo: s.n, 1999. 165 p. Tese (Doutorado em Ciências). Universidade Federal de Säo Paulo. Escola Paulista de Medicina. (Unifesp - Biblioteca Central)

FLICK, Uwe. Introdução à pesquisa qualitativa. 3 ed. São Paulo: Artmed, 2009.

FRANÇA, Genival Veloso. Medicina Legal. 8 ed. Rio de Janeiro: Guanabara, 2008.

FREITAS JUNIOR, Roberto Mendes. Drogas - Comentários à Lei no 11.343 de 23/08/2006. 1 ed. São Paulo: Juarez de Oliveira, 2006. 
FREUD, Sigmund. Mal estar na civilização. São Paulo: Penguin e Companhia das Letras, 2011.

FUNDAÇÃO OSWALDO CRUZ. Estimativa do número de usuários de crack e/ou similares nas Capitais do País. Livreto domiciliar. São Paulo, 2013. Disponível em: $<$ http://portal.fiocruz.br/pt-br/content/maior-pesquisa-sobre-crack-j\%C3\%A1-feita-nomundo-mostra-o-perfil-do-consumo-no-brasil>. Acesso em: 14 de janeiro de 2014.

. Estimativa do número de usuários de crack e/ou similares nas Capitais do País. Livreto epidemiológico. São Paulo, 2013.Disponível em:

$<$ http://portal.fiocruz.br/pt-br/content/maior-pesquisa-sobre-crack-j\%C3\%A1-feita-nomundo-mostra-o-perfil-do-consumo-no-brasil.> Acesso em: 14 de janeiro de 2014.

GALDURÓZ, José Carlos F. et al. Levantamento Nacional sobre o Consumo de Drogas Psicotrópicas entre Estudantes do Ensino Fundamental e Médio da Rede Pública de Ensino nas 27 Capitais Brasileiras. CEBRID. Secretaria Nacional Antidrogas. Gabinete de Segurança Institucional. São Paulo. 2004.

GALVÃO, L.C.C. Medicina Legal. 1 ed. São Paulo: Santos Editora, 2008.

GARFINKEL, Harold. Conditions of Successful Degradation Ceremonies. American Journal of Sociology, vol. 61, n 5, pp. 420-424. (Mar., 1956), The University of Chicago Press. Disponível em: <http://www.jstor.org/stable/2773484>. Acesso em: 20 dez. 2013.

GIACOMOLLI, Nereu José. Análise crítica da problemática das drogas e a Lei 11.343/2006. Revista Brasileira de Ciências Criminais, São Paulo, v.16, n.71, p.181-204, mar./abr. 2008.

GIUSTI, J. S.; SANUDO, A.; SCIVOLETTO, S. Diferenças no padrão de uso de drogas adolescentes do sexo masculino e feminino em tratamento. Revista Brasileira de Psiquiatria, São Paulo, v. 24, p. 80-82, 2002.

GOFFMAN, Erving. Estigma: notas sobre a manipulação da identidade deteriorada. $4^{\mathrm{a}}$ ed. Rio de Janeiro: LTC, 1988.

GOMES, Bruno Ramos; ADORNO, Rubens de Camargo Ferreira. Tornar-se "noia": trajetória e sofrimento social nos "usos de crack" no centro de São Paulo. Etnográfica, v.15, n.3, 569-586, 2011. 
GOMES, Luiz Flávio (Org.). Lei de Drogas Comentada. Lei $\mathbf{n}^{\mathbf{0}}$ 11.343/06. 3 ed. São Paulo: Revista dos Tribunais, 2008.

GRECO FILHO, Vicente; RASSI, João Daniel. Lei de Drogas Anotada. Lei no 11.343/06. 3 ed. São Paulo: Saraiva, 2009.

GRILLO, Carolina Christoph; POLICARPO, Frederico; VERISSIMO, Marcos. A "dura" e o "desenrolo": efeitos práticos da nova lei de drogas no Rio de Janeiro. Rev. Sociol. Polit. - online, v.19, n.40, pp. 135-148, 2011,

GUIMARÃES, Isaac Sabbá. Nova lei antidrogas comentada: crimes e regime processual penal: Lei 11.343, de 23 de agosto de 2006. 2 ed. Curitiba: Juruá, 2008.

GUIMARÃES, Marcelo Ovídio Lopes (Org.). Nova Lei Antidrogas Comentada - Lei no 11.343/06. São Paulo: Quartier Latin, 2007.

INSTITUTO LATINO AMERICANO DAS NAÇÕES UNIDAS PARA A PREVENÇÃO DO DELITO E TRATAMENTO DO DELINQUENTE (ILANUD). Revista. As Drogas Ilícitas em São Paulo. Revista nº 15. Imprensa Oficial, 2001.

JESUS, Damásio Evangelista. Lei de Drogas Anotada. Comentário à Lei no 11.343/2006. 9 ed. São Paulo: Saraiva, 2009.

JESUS, Maria Gorete Marques. (Org.). Prisão Provisória e Lei de Drogas: estudo sobre os flagrantes de tráfico de drogas na cidade de São Paulo. Núcleo de Estudos da Violência (NEV-USP), 2011. Disponível em:

<http://www.nevusp.org/downloads/down254.pdf>. Acesso em: 25 dez. 2013.

KARAM, Maria Lúcia. "Guerra às drogas" e criminalização da pobreza. In: ZILIO, Jacson Luiz; BOZZA, Fábio da Silva (Org.). Estudos críticos sobre o sistema penal. Curitiba: LedZe, p.679-697, 2012.

KUMPEL, Vitor Frederico. A Nova Lei de Tóxicos: as principais inovações. Revista Magister de Direito Penal e Processual Penal. São Paulo, ano III, n.16, p.26-31, fev.mar./2007

LARANJEIRA, Ronaldo. Evolução do consumo de crack em coorte com histórico de tratamento. Revista de Saúde Pública. Disponível em: 
$<$ http://www.uniad.org.br/index.php?option=com_content $\&$ view=article $\&$ id=10604:evoluc ao-do-consumo-de-crack-em-coorte-com-historico-de-tratamento\&catid=51:dependenciaquimica-artigos\&Itemid=93>. Acesso em: 14 out. 2011.

LEAL, João José; LEAL Rodrigo José. Controle Penal das Drogas: Estudo dos Crimes Descritos na Lei no 11.343/06. Curitiba: Juruá, 2010.

LIMA, Rita de Cassia Ferreira. Sociologia do desvio e Interacionismo. Tempo Social. Rev. Sociol. USP, S. Paulo, v.13, n.1. p.185-201, maio de 2001.

LIMA, Sérgio Alves. A clínica do possível: tratando de dependentes de drogas na periferia de São Paulo. 2 ed. São Paulo: Casa do Psicólogo, 2008.

MARCÃO, Renato. A Nova Lei de Tóxicos: Plantio e Porte para uso próprio - o art. 28 na visão do Supremo Tribunal Federal. Revista Magister de Direito Penal e Processual Penal. São Paulo, ano III, n.16, p.5-8, fev.-mar./2007.

MENDONÇA, Andrey Borges de; CARVALHO, Paulo Roberto Galvão (Org.). Lei de Drogas: Lei 11.343, de 23 de agosto de 2006. Comentada artigo por artigo. 3 ed. São Paulo: Método, 2012.

MINAYO, Maria Cecília de Souza (Org.). Pesquisa Social: Teoria, método e criatividade. 30 ed. Petrópolis/RJ: Vozes, 2011.

MINGARDI, Guaracy; GOULART, Sandra. As drogas ilícitas em São Paulo: o caso da cracolândia. Revista do ILANUD, São Paulo, n.15, p.3-49, 2001.

MOURA, Julio Victor dos Santos. A Nova Lei de Tóxicos: A Posse e o Porte. Revista Magister de Direito Penal e Processual Penal. São Paulo, ano III, n.14, p.97-102, outnov/2006.

. A posse ou porte de drogas e a nova lei antitóxicos. Revista IOB de Direito Penal e Processual Penal, Porto Alegre, v. 8, n.43, p.50-56, abr./mai. 2007.

MUAKAD, Irene Batista. A cocaína e suas formas de consumo. São Paulo, 2009. Disponível em:

<http://www.mackenzie.br/fileadmin/Graduacao/FDir/Artigos/artigos_2009/irene_04_09.p df $>$. Acesso em: 20 out. 2010. 
OLIVEIRA, Lúcio Garcia. Avaliação da cultura do uso de crack após uma década de introdução da droga na cidade de São Paulo. - Crack cocaine culture evaluation a decade after its introduction in the city of São Paulo. São Paulo: s.n, 2007. 315 fls. Tese (Doutorado em Ciências). Universidade Federal de São Paulo. Escola Paulista de Medicina. (Unifesp Biblioteca Central).

; NAPPO, Solange Aparecida. Crack na cidade de São Paulo: acessibilidade, estratégias de mercado e formas de uso. Rev. psiquiatr. clín. - online, vol.35, n.6, pp. 212 218, 2008.

.; NAPPO, Solange Aparecida. Caracterização da cultura de crack na cidade de São Paulo. Padrão de uso controlado. Revista de Saúde Pública, 2008.

RAUPP, Luciane Marques. Circuitos de uso de crack nas cidades de São Paulo e Porto Alegre: Cotidiano, práticas e cuidado. 2011. Tese (Doutorado em Saúde Pública). Universidade de São Paulo: Faculdade de Saúde Pública. São Paulo, 2011.

. Circuitos de uso do crack na região central da cidade de São Paulo. Rio de Janeiro: ABRASCO, 2009.

. Uso de crack e violência na Cracolândia. Saúde e Sociedade, São Paulo, v. 18, supl. 3, p. 370, 2009.

; ADORNO, Rubens de Camargo Ferreira. Circuitos de uso de crack na região central da cidade de São Paulo (SP, Brasil). Ciênc. saúde coletiva - online, vol.16, n.5, pp. 2613-2622, 2011.

REALE JR., Miguel (Cord.). Drogas: Aspectos Penais e Criminológicos. Primeiro Encontro de Mestres e Doutores do Departamento de Direito Penal da Faculdade de Direito da USP. Rio de Janeiro: Forense, 2005

REGHELIN, Elisângela Melo. Redução de danos: prevenção ou estímulo ao uso indevido de drogas injetáveis. São Paulo: Revista dos Tribunais, 2002.

RIBEIRO, L.A.; SANCHEZ, Z.V.D.M.; NAPPO, S.A. Estratégias desenvolvidas por usuários de crack para lidar com os riscos decorrentes do consumo da droga. J Bras. Psiquiatr., v.59, n.3, p.210-8, 2010. 
RELATÓRIO ANUAL DA JUNTA INTERNACIONAL DE FISCALIZAÇÃO DE ENTORPECENTES (JIFE). 2009. Disponível em:

$<\mathrm{http}: / /$ www.unodc.org/documents/southerncone//noticias/2010/02/jife/INCB_2009_report _ENG.pdf>. Acesso em: 18 out. 2010.

RIBEIRO, Marcelo et al. Causes of death among crack cocaine users. Rev. Bras. Psiquiatria - online, v.28, n.3, pp.196-202, 2006.

; LARANJEIRA, Ronaldo. O tratamento do usuário de crack. São Paulo: Artmed, 2012. p.23.

RIBEIRO, Maurides de Melo. Políticas públicas e a questão das drogas: o impacto da política de redução de danos na legislação brasileira de drogas. 2007. Dissertação (Mestrado em Direito). Universidade de São Paulo, 2007.

RODRIGUES, Diego Schaurich et al. Conhecimentos produzidos acerca do crack: uma incursão nas dissertações e teses brasileiras. Ciênc. saúde coletiva - online, v.17, n.5, pp.1247-1258, 2012.

RODRIGUES, Luciana Boiteux de Figueiredo. Controle penal sobre as drogas ilícitas: o impacto do proibicionismo no sistema penal e na sociedade. 2006. Dissertação (Mestrado em Direito).Universidade de São Paulo, 2006.

ROMANINI, Moises; ROSO, Adriane. Mídia e crack: promovendo saúde ou reforçando relações de dominação?. Psicol. cienc. prof. - online, v.32, n.1, pp.82-97, 2012.

SÁ, Alvino Augusto. Criminologia Clínica e Psicologia Criminal. 2 ed. São Paulo: Revista dos Tribunais, 2010.

. SHECAIRA, Sérgio Salomão (Org.). Criminologia e os Problemas da Atualidade. São Paulo: Atlas, 2008.

SANTOS, Juarez Cirino dos. A criminologia radical. 2. ed. Curitiba: ICPC / Lumen Juris, 2006. 139p.

SANTOS, Maria de Fátima de Souza; ACIOLI NETO, Manoel de Lima and SOUSA, Yuri Sá Oliveira. Representações sociais do crack na imprensa pernambucana. Estud. psicol. (Campinas) - online, vol.29, n.3, pp. 379-386, 2012. 
SECRETARIA NACIONAL ANTIDROGAS (SENAD). GABINETE DE SEGURANÇA INSTITUCIONAL. Livreto Informativo sobre: Drogas Psicotrópicas. São Paulo, s.d.

\section{GABINETE DE SEGURANÇA INSTITUCIONAL. I Levantamento} Domiciliar Sobre o Uso de Drogas Psicotrópicas no Brasil. São Paulo, 2001.

SENADO FEDERAL. Projeto de Lei $\mathbf{n}^{\mathbf{0}}$ 115/2002. Dispõe sobre o Sistema Antidrogas; sobre a prevenção, a repressão e o tratamento; define crimes, regula o procedimento nos crimes que define e dá outras providências. (VOLUME II). Disponível em: $<$ http://www.senado.gov.br/atividade/materia/detalhes.asp?p_cod_mate=50227>. Acesso em: 07 jan. 2014.

SHECAIRA, Sérgio Salomão. A Lei de Drogas e o crime de tráfico. Boletim IBCCrim, São Paulo, v.15, n.177, p. 2-3, ago., 2007.

. Criminologia. 2 ed. São Paulo: Revista dos Tribunais, 2008.

SILVA, Gilberto Lucio da (Org.). Drogas: Políticas e práticas. São Paulo: Roca, 2011.

SILVA, Jorge. Criminologia Crítica - Segurança e Polícia. 2 ed. Rio de Janeiro: Forense, 2008.

SILVA, Ovandir Alves. Toxicologia da cocaína. Porto Alegre : Artmed, 1999.

SOUZA, Luciano Anderson. Punição criminal ao porte de entorpecentes para uso próprio e irracionalismo repressivo. Uma ainda necessária reflexão. Revista Brasileira de Ciências Criminais, São Paulo, v.19, n.88, p.167-186, jan./fev. 2011.

TAFARELLO, Rogério Fernando. Drogas: falência do proibicionismo e alternativas de política criminal. 2009. Dissertação (Mestrado em Direito). Universidade de São Paulo. 2009.

UNIDADE DE PESQUISAS EM ÁLCOOL E DROGAS (UNIAD), Departamento de Psiquiatria, Universidade Federal de São Paulo. Cocaína. Disponível em: <http://www.uniad.org.br/index.php?option=com_content $\& v i e w=a r t i c l e \& i d=84 \&$ Itemid=9 6>. Acesso em: 14 out. 2011. 
UNITED NATIOS OFFICE ON DRUGS AND CRIME (UNODOC). Cem anos de controle internacional de drogas. 2010. Disponível em: $<$ http://www.unodc.org/documents/data-and-

analysis/Studies/100_Years_of_Drug_Control.pdf>. Acesso em: 18 out. 2010.

A ameaça do Narcotráfico nas Américas. 2010. Disponível em: <http://www.unodc.org/documents/data-andanalysis/Studies/100_Years_of_Drug_Control.pdf>. Acesso em: 18 out. 2010.

Comportamento de risco entre jovens no Brasil: uso de drogas e gravidez na adolescência. 2010. Disponível em:

<http://www.unodc.org/pdf/brazil/publicacoes/YouthRisk_takingBehaviorBrazi.pdf>. Acesso em: 18 out. 2010.

Cultivo da coca na região andina. 2008. Disponível em: <http://www.unodc.org/documents/crop-monitoring/Andean_report_2008.pdf >. Acesso em: 18 out. 2010.

. Guia de aplicação de programas de formação para famílias sobre prevenção ao abuso de drogas. Disponível em:

<http://www.unodc.org/pdf/youthnet/family\%20based/FINAL_ENGLISH_version\%20for \%20PRINTING\%20received\%20120209.pdf>. Acesso em: 18 out. 2010.

- Monitoramento do cultivo de coca na Bolívia. Disponível em <http://www.unodc.org/unodc/en/crop-monitoring/index.html?tag=Bolivia>. Acesso em: 18 out. 2010.

Monitoramento sobre o cultivo de coca no Peru. Disponível em: <http://www.unodc.org/unodc/en/crop-monitoring/index.html?tag=Peru. Acesso em: 18 out. 2010.

- Pesquisa sobre o cultivo de coca na Colômbia. Disponível em http://www.unodc.org/unodc/en/crop-monitoring/index.html?tag=Colombia. Acesso em: 18 out. 2010.

. Políticas públicas em contextos de violência relacionados ao consumo de álcool e outras drogas. Disponível em: <http://www.unodc.org/southerncone/pt/drogas/politicaspublicas-em-contextos-de-violencia-relacionados-ao-consumo-de-alcool-e-outrasdrogas.html>. Acesso em: 18 out. 2010. 
Princípios sobre o tratamento na dependência de drogas. Disponível em: <http://www.unodc.org/pdf/youthnet/family\%20based/FINAL_ENGLISH_version\%20for \%20PRINTING\%20received\%20120209.pdf>. Acesso em: 18 out. 2010.

. Reduzindo as consequências sociais e de saúde do uso de drogas: uma abordagem abrangente. Disponível em:

$<$ http://www.unodc.org/documents/prevention/Reducing-adverse-consequences-drugabuse.pdf>. Acesso em: 18 out. 2010.

. Relatório Mundial Sobre Drogas. Disponível em: <http://www.unodc.org/documents/wdr/WDR_2010/World_Drug_Report_2010_lores.pdf $>$. Acesso em: 18 out. 2010.

VARGENS, Renata Werneck; CRUZ, Marcelo Santos; SANTOS, Manoel Antônio. Comparação entre usuários de crack e de outras drogas em serviço ambulatorial especializado de hospital universitário. Rev. Latino-Am. Enfermagem - online, v.19, n.spe, pp. 804-812, 2011.

VIOLA, Thiago Wendt et al. Tomada de decisão em dependentes de crack: um estudo com o Iowa Gambling Task. Estud. psicol. (Natal) - online, v.17, n.1, pp. 99-106, 2012.

WEIGERT, Mariana de Assis Brasil. Uso de Drogas e Sistema Penal: Entre o proibicionismo e a redução de danos. Rio de Janeiro: Lumen Juris, 2010.

ZACCONE, Orlando. Sistema penal e seletividade punitiva no tráfico de drogas ilícitas. Discursos Sediciosos: crime, direito e sociedade. Rio de Janeiro, n.14, p.181-198, anual. 2004.

ZAFFARONI, Eugenio Raul; OLIVEIRA, Edmundo. Criminologia e Política Criminal. Rio de Janeiro: GZ Editora, 2010. 


\section{APÊNDICE 1 - RoteIro das EnTREVISTAS COM USUÁRIos}

- Quais foram os motivos que o levaram a buscar o tratamento?

- Alguma vez teve vontade de interromper o tratamento? Se sim, o que te fez pensar sobre isso? O que te fez não desistir?

- Já se sentiu diferente das outras pessoas por ser usuário de drogas? Pode citar uma situação em que isso ocorreu?

- Já teve passagem pela polícia? Se sim, como isso aconteceu?

- Já teve passagem pelo fórum? O que aconteceu lá?

- Acha que teve algum aprendizado quando cumpriu o que foi determinado pelo juiz? 


\section{APÊNDICE 2 - Roteiro dAS EnTREVISTAS COM ProfisSIONAIS}

- Existem fatores que podem ser associados à busca de tratamento pelo usuário de crack?

- Para aqueles que interrompem o tratamento existem fatores recorrentes? E para a retomada, existem fatores recorrentes?

- Os usuários se sentem diferentes das outras pessoas, por quais motivos?

- Como você vê a relação dos usuários com a polícia ou a Justiça?

- Quais estratégias você acredita que seriam importantes para incentivar os usuários de crack a buscarem tratamento? 


\section{APÊNDICE 3 - TranSCRIÇÃo das ENTREVISTAS COM USUÁRIOS}

\section{ENTREVISTADO: P1}

Arquivo de Áudio:131607-001

Tempo: 00:16:03

Pesquisadora - Então começando. Hoje é dia 17 de junho de 2013. Qual é o seu nome?

P1 - Sim. Eu sou (...), né? Então pode falar o nome todo?

Pesquisadora - Pode!

P1 - Eu sou um adicto. Eu sou um que se tornou escravo perante o uso das drogas, por último o crack. Mas eu estou limpo hoje, graças a Deus, há 46 dias.A coisa mais importante que eu tenho éo dia de hoje, não é, Gabriela?

Pesquisadora - Eu vou te perguntar ainda, de novo.

P1 - Já gravou?

Pesquisadora - Gravou. Qual é a sua idade?

P1 - Cidade de quê?

Pesquisadora - Qual é a sua idade?

P1 - Ah, entendi cidade. Eu tenho 29 anos.

Pesquisadora - 29? E escolaridade?

P1 - Eu tenho segundo grau completo.

Pesquisadora - Você mora com quem, (...)?

P1 - Pai, mãe, uma irmã e uma gatinha.

Pesquisadora - E uma gatinha? E você já morou alguma vez na rua?

P1 - Eu já fiquei na rua por algum tempo já, devido ao uso compulsivo, obsessivo, abusivo da droga, do crack, mas hoje eu moro com meus pais. Eu tenho ondede voltar para casa.

Pesquisadora - Que bom!

P1 - Graças a Deus.

Pesquisadora - E por quanto tempo você usou crack?

P1 - Por quanto tempo? Cerca de cinco anos, um ciclo de internação muito grande. Inclusive há cerca de duas semanas atrás estava internado. Cerca de cinco anos que eu faço uso do crack e hoje estou limpo. Ressalto, a coisa mais importante, 46 dias conquistados hoje, que é o meu tesouro: estar limpo. 
Pesquisadora - Verdade. E por quais motivos você buscou tratamento? Você me disse que você foi internado algumas vezes. Se você puder me contar uma dessas vezes como foi... P1 - Sim. Eu acho que em 2009, 2008 para 2009. Em 2009, no começo de 2009, eu tive a minha primeira internação devido ao uso do crack, não é? Mas outras drogas já ficou para trás, maconha, cocaína, né? O álcool... Aí eu fiz essa substituição pelo crack e essa foi a primeira internação minha, de quatro meses, há cerca de quatro ou cinco anos atrás; fiz um tratamento de quatro meses e no mesmo dia voltei a usar. Aí depois foi um ciclo como eu já falei, anterior. Não parei mais de ser internado. Internações involuntárias, né? Involuntárias. Devido ao uso abusivo. Fiquei em tratamento de seis meses, quatro meses, três meses... E que no momento não era aceito por mim, da internação. Mas depois, com a cabeça, depois de 15 dias já no tratamento, eu fui ver que está sendo melhor para mim. Sendo melhor para mim. Foi mais ou menos isso, assim.

Pesquisadora - E o crack não foi a sua primeira droga?

P1 - Não foi, não foi minha primeira droga. Hoje estou com 29 anos; aos 16 anos de idade comecei a fumar maconha, e daí foicinco anos só usando maconha; e depois teve a substituição por cocaína, cinco anos também direto..., a qual me deixou também numa degradação, desleixo, por fim a perca ( sic) de controle e foi a noiva branca, a cocaína, não é? E daí teve essa perca (sic) de controle final da cocaína e... Como não fazia mais a cabeça essa droga, aí eu fui para o crack onde que eu fiz a cabeça e deu maior treta e todos os dias foi de manter a coisa mais importante, 46 dias que eu não fumo. É isso que tenho que falar..., você vai ouvir eu falar isso direto.

Pesquisadora - Não, está certo. Tem que falar mesmo. É uma super vitória.

P1 - Nossa! Mais ou menos isso?

Pesquisadora - E quais foram... É. Está super certo. Você me fala o que você quiser. Eu te faço as perguntas... Se eu quiser saber mais alguma coisa, eu vou te perguntando. Pode ficar super tranquilo. Não é nada formal. Quais foram os motivos...

P1 - Mas a gente fica nervoso mesmo, né?

Pesquisadora - É? Mas não precisa ficar nervoso. É uma conversa. Não precisa, de jeito nenhum. Se eu falar que estou nervosa, você não ia falar para eu não ficar?

P1 - Para ficar à vontade.

Pesquisadora - Então pronto. Quais foram os motivos que te levaram a buscar o tratamento? O que te faz querer ficar livre? 
P1 - Essa é uma pergunta especial, né? Muito especial pra mim. Bom, eu não sou um adito, né? Então, eu venho nessa jornada, contínua, já faz cerca de cinco anos que eu estou em tratamento. Mas a recuperação, portanto, foi uma ação..., ação criativa. Todos os dias... tentar acordar cedo, fazer o que as pessoas fazem naturalmente, sempre, sem precisar usar droga; trabalho, ter relações... um relacionamento prático com o próximo, pai e mãe, as pessoas de casa.

E isso, você perguntou o que me faz buscar o tratamento, não é isso? Então vamos lá. Ser humano. Essa palavra "ser humano" me atrai, né? Eu preciso hoje, todos os dias, me ver como 'um ser humano'. Com sentimentos. E alguns, 24 horas atrás no uso de drogas..., totalmente... Os níveis mais elevados como a capacidade de amar, de se importar com o outro... Compaixão, interesse com o outro eu não tinha. Nem comigo, ainda mais com os outros. Então essas coisas assim me faz querer buscar o tratamento dia após dia; um dia de cada vez; sem usar alterador de humor - o crack, o que mais me mata. Então é não procurar essa droga, como outras. E para mim é uma batalha, uma vitória todos os dias, né? Todos os dias e ser um filho melhor. Por isso eu procuro a recuperação, o tratamento; sou um filho melhor e um membro como já foi falado lá..., produtivo de uma sociedade. E o principal, não morrer antes do tempo de Deus, porque o crack, como outras drogas... Mas, na minha vida foi assim com o crack, deu para se ver muitos que morrem, né? Muitos sem ter..., muito humilhados, né? Quem não é humilde é humilhado, por sinal, isso já foi dito também. Então assim, não morrer antes do tempo de Deus, que é o que eu quero para mim. Então eu agradeço pelo dia de hoje. É mais ou menos isso. É ser um ser humano, minha meta no dia de hoje, com sentimentos. Dói, é dolorido. Aí tirava da droga... Ainda hoje acordei com um vazio enorme e não precisei da droga, né? É existencial... Estou falando muito, não é?

Pesquisadora - Não, está nada, está bom!

P1 - Até agradeço. Estou vendo que a senhora é uma artista. É só por hoje!

Pesquisadora - Alguma vez você teve vontade de interromper o tratamento?

P1 - Aí cansa também.

Pesquisadora - O tratamento cansa?

P1 - Sim.

Pesquisadora - Por quê?

P1 - Por várias vezes eu fiz isso. Eu interrompi o crescimento... O crescimento sem drogas eu interrompi. Interrompi esse crescimento do tratamento pra buscar mais droga. Aí eu vi que só o querer é pouco estar longe das drogas. Como eu falei antes, tem que... É 
necessário... daí qualquer... O objetivo, o ideal que é a coisa mais importante hoje é não usar.

Pesquisadora - Entendo. E você já se sentiu diferente das outras pessoas, por ser usuário e agora ex-usuário de droga?

P1 - Essa é uma pergunta forte também. Ainda hoje tenho vários complexos, né? Tenho vários complexos dentro de mim... Aí eu digo pra mim que sou diminuído como ser humano, né? A sociedade não me aceita. Algumas coisas dentro de mim, os medos, o famoso medo que não me deixa crescer. E por muitas vezes eu tenho medo de dar certo, né? Aí eu fíco parado... Mas como foi falado também, há esperança. Ela vai morrer de tanto eu ficar sentado e não correr atrás do objetivo, então, cada vez mais, se eu não brecar o tratamento, a tendência é melhorar. Com vários profissionais - quando meu recurso for pouco, né, aí têm psiquiatra, psicólogo, outros grupos hoje que, dentro dos Narcóticos Anônimos que eu faço parte, de uma irmandade sem fins lucrativos para homens e mulheres. Mundialmente o Narcóticos Anônimos é falado - dê um abraço para todos os companheiros lá também todos eles, que muitas vezes eu penso neles para não usar drogas; um dia de cada vez. Eu sei que tem, múltiplos anos, acima de dois anos, um ano, um dia, eu penso nos outros, em alguns companheiros... Ali eu sou igual, né? Eu sou igual. Lá não preciso me diminuir. Como foi a pergunta? Não preciso..., né, ser mais. Eu penso na igualdade das pessoas que não estão usando drogas que encontraram uma nova maneira de viver. Aí tem assim: "Enquanto eu seguir esse caminho, não tenho nada a temer". Embora tendo alguns complexos, né? Embora tenho alguns complexos. Mas é inferior, a negatividade vem na direta, e tem que fazer a situação ao contrário, né? Por isso que é um leão a cada dia. Entrei na droga um dia. Sim. Quem é culpado? né?

Pesquisadora - E você consegue me dar um exemplo de uma situação prática na sua vida, que você se sentiu diminuído, que você se sentiu diferente? Se você não quiser, você não precisa.

P1 - Sim. Eu posso sim. Posso falar com droga e sem droga?

Pesquisadora - Pode!

P1 - Com droga, muita gente da sociedade sim, aplaudiram falando: "Vai morrer na droga". Não será mais tolerado isso, né, por hoje. Há 46 dias hoje longe do crack, graças a Deus! Eu sou o (...), né? Não é mais tolerado esse lance que "uma vez drogado sempre drogado". Nós nos recuperamos. São alguns slogans que eu trago pra minha vida. A sociedade muitas vezes - eu tô falando no uso - aplaudia: "Vai morrer lá", né? Mas a grande realidade é uma carência 
enorme que nos faz, que me faz - fazia, né? -, usar droga. Um complexo louco que até hoje... A procura da batida perfeita, mas não tem, né? Então assim. O culpado, se tem um culpado, sou eu. Mas eu tenho que diminuir essa culpa cada vez mais pra me manter limpo. É existencial... né? A pergunta?

Pesquisadora - Tá. Deixa eu lhe fazer outra então. Você já teve alguma passagem pela polícia?

P1 - Nunca tive. (risos)

Pesquisadora - Nunca teve?

P1 - Nunca tive.

Pesquisadora - Mas você nunca foi abordado pela polícia? Não precisa ter assinado nada. A polícia nunca chegou em você?

P1 - Ah, sim. Com certeza.

Pesquisadora - E como foi essa abordagem da polícia? Foi legal? Foi tranquila?

P1 - Faz muito tempo que eu não passo por um enquadro da Polícia Militar, Civil, ou o que seja, né? Mas sempre comigo, [...], foi com respeito que vieram, né? Há muito tempo, acho que faz cerca de... Mais de cinco anos que eu não tomo enquadro, já é muito louco isso, mas muito tempo. Eu não tenho nada para falar a respeito, sabe? Não tenho nada para falar a respeito. Só que nunca houve...

Pesquisadora - Não, tudo bem. Só me fala o que quiser.

P1 - Muito pouco, muito pouco.

Pesquisadora - Você sabe que portar droga é crime? Você sabia?

P1 - (risos) Portar droga é crime?

Pesquisadora - Você já sabia ou estou te contando isso agora? Pode não saber. Eu posso te contar um monte de coisas que você não vai saber que é crime. É que eu sou uma advogada.

P1 - Oh, advogada!

Pesquisadora - Não, porque eu vou te perguntar...

P1 - Sim. É crime. É crime?

Pesquisadora - É.Você já sabia?

P1 - Mas longe da droga, como é crime?

Pesquisadora - Não. Essa discussão é enorme. O que eu vou te perguntar é: alguma vez, pelo fato de ser crime... 
P1 - Como é que se eu quero mudar... Eu mudo não usando, né? Hoje, não usando, tô contribuindo. Seja pros corruptos, né? Que se for falar, não é?...

Pesquisadora - Claro! Eu só te perguntei isso para te perguntar outra coisa. Sabendo que é crime e nessas ocasiões em que você tomou o enquadro, por exemplo.

P1 - Sim.

Pesquisadora - Alguma vez isso te fez pensar em procurar o tratamento?

P1 - Foi lá atrás. Ainda não tinha sido aparente a doença da adição, não tinha sido aparente pra mim. E como eu falei, não posso falar outras coisas. Assim, para a sociedade, assim como eu já falei, pra me sentir ser humano, um membro produtivo, por isso eu procurei um tratamento. Mas não... E não contribuir com o crime, né? Para os corruptos... Polícia... Desculpa eu falar, mas uma realidade está nos meus olhos. Muitas vezes eu vi várias situações... Fardados... Eu vi várias situações...

Pesquisadora - Então, não foi isso que te chamou atenção?

P1 - Não, isso não. Tinha uma... O que fizeram assim pra mim foi minha família e pra mim, “olha, vamos nos tratar?” Foi pra crescimento pessoal. Não por causa de polícia e ladrão.

Pesquisadora - Entendi. (...), obrigada. É isso. Minha última pergunta ia ser sobre se você já teve alguma passagem pelo Fórum, por causa de droga. Mas você me disse que não teve problema com a polícia, então...

P1 - Nunca tive.

Pesquisadora - Então não teve. Por isso que não faço a pergunta. E a gente acabou.

P1 - Está certo. Desculpe o barulho, que algumas vezes saio do raciocínio, mas...

Pesquisadora - Não. Nenhum. Na verdade vou desligar agora... 


\section{ENTREVISTADO: P2}

Arquivo de Áudio:130624-001.

Tempo: 00:56:28

Pesquisadora-Hummm. Não atraso. Mas o que eu não gosto? Você marca com uma pessoa, assim: "ah, vamos jantar. Vamos marcar às 9 h". E aí você chega no lugar às $9 \mathrm{~h}$ e a pessoa chega às 10h. Pô! Fiquei uma hora sozinha...

Pesquisadora - O seguinte, como eu falei lá já para vocês, o que é a minha pesquisa? Eu analiso de que forma - isso está escrito aqui - de que forma a atuação da polícia influencia os usuários de crack na busca pelo tratamento. Os usuários ou ex-usuários na busca pelo tratamento. Então eu faço algumas perguntas. Você me responde o que você quiser. O que você não quiser não responde. Se você quiser parar de responder, você para. Se você quiser falar de outras coisas, você fala. A fala é sua. Por que eu decidi fazer essa pesquisa na verdade? Porque quando a gente faz as coisas lá na Faculdade de Direito, a gente só olha para o livro. E aí fica todo o mundo resolvendo as coisas, sem conversar com as pessoas que vivem isso, e o que eu acho é que vocês tem muito mais para falar do que a gente. Por isso que eu decidi conversar com vocês, entendeu?

P2 - Mas eu não tenho muito que falar. Às vezes eu acho que tenho muito que falar, mas tem muita coisa pra mim aprender ainda.

Pesquisadora - O ponto é... É essa a questão. Você não vai ter que me dizer... Você não vai ter que fazer uma teoria. Você vai ter que contar da sua vida. Só responder as minhas perguntas. É como se você me perguntasse: Gabriela, por que você escolheu fazer Direito? E aí eu ia te contar da minha decisão, se está certo ou se está errada, se todo o mundo pensa assim ou não, não sei. Só sei que é o meu jeito de ver o mundo, entendeu? A participação é através de uma entrevista que eu faço as perguntas...

P2 - Fala. Desculpa.

Pesquisadora - Claro. Se você tiver qualquer problema, pode me procurar, aqui no PROAD, você já está aqui e eu só faço entrevista com o pessoal aqui do PROAD. Você pode, enfim, responder o que você quiser, desistir à hora que você quiser. É voluntária a participação. E eu nunca vou te identificar. Então no trabalho nunca vai ter o seu nome, tá? Eu não posso... P2 - Eu estou muito empolgado com esse assunto não, quero muito é te ajudar, mas também não vou mentir pra você para tentar te ajudar, entendeu? Sinceramente eu estou ... 
Pesquisadora - Não! Claro que não! Não é pra você mentir!

P2 - Tentando aqui... É, eu mentir pra você assim, falar uma coisa: “oh, P2, vamos falar qualquer coisa aqui para...", não é?

Pesquisadora - Mas você não quer falar? Nem quer saber quais são as perguntas?

P2 - Não estou empolgado, assim. Quando estou empolgado eu solto a voz, falo mais que a nega do leite, tem hora que eu tô de lua.

Pesquisadora - Mas você não quer nem responder às perguntas?

P2 - Dependendo.

Pesquisadora - Então. Você quer responder? Quer ver as perguntas e não responder? O que eu ponho aqui? Não quer nem saber?

P2 - Comprei ontem.

Pesquisadora - Hein?

P2 - Comprei ontem.

Pesquisadora - O seu celular? Legal.

P2 - Olha atrás, ele é bonitinho. Azul. Esse azul dele.

Pesquisadora - Bonitinho. Legal, uma câmera boa. Tem TV?

P2 - Tem.

Pesquisadora - Então. Então você quer que primeiro eu faça as perguntas para você ver o que é e aí depois se você achar que deve responder, você assina para mim o seu consentimento da pesquisa?

P2 - Tá. Mas você quer fazer as perguntas para mim?

Pesquisadora - Para você me responder. As perguntas são simples.

$\mathbf{P 2}$ - Hum. Isso que você quer, isso está aqui?

Pesquisadora - Não. Isso aqui é um Termo de Consentimento. Isso aqui você falando o seguinte: "Eu... Declaro ter sido adequadamente informado sobre o Termo de Participação...".

P2 - Tá, entendi. Autorização.

Pesquisadora - Exatamente. Você está me autorizando só a fazer pesquisa. Você responde o que você quiser, desiste à hora que você quiser, não tem problema.

P2 - Isso eu já entendi. Tá.

Pesquisadora - Beleza?

P2 - Vou tentar.

Pesquisadora - Então, você pode assinar... 
Pesquisadora - Agora sou eu. A [...] vai assinar no meio.

P2 - Onde? Aqui?

Pesquisadora- É.Nesse espacinho aqui.

P2 - Em cima?

Pesquisadora - É.

P2 - Tudo?

Pesquisadora - Tudo o quê?

P2 - Nome?

Pesquisadora - Como você quiser assinar.

Pesquisadora - Tudo estiloso. Olha aí teu [inicial do nome], todo estiloso.

P2 - Só para me animar.

Pesquisadora - Não é para te animar. Vivo te elogiando.

P2 - Eu sei. Eu estou preocupado com teu elogio assim sem necessidade.

Pesquisadora - Por que sem necessidade, P2?

P2 - Huтmm... Acho tão...Tão como você tá achando não.

Pesquisadora - Então talvez eu te ache mais legal do que você se acha. Só isso. Mas quem decide a necessidade do meu elogio sou eu, não é você.

P2 - Quem decide a necessidade do quê?

Pesquisadora - Do meu elogio, do que eu faço - sou eu. Depois a [...] assina no meio e aí fica com vocês. É o seguinte, qual é o seu nome inteiro?

P2 - P2.

Pesquisadora - P2. Quantos anos você tem?

P2 - Quantos anos? 28.

Pesquisadora - 28? Qual é o seu grau de escolaridade?

P2 - Parei... Estudei três anos na minha vida. Parei na $3^{\text {a }}$ Série.

Pesquisadora $-3^{\mathrm{a}}$ Série? Estudou muito mais de três anos. $3^{\mathrm{a}}$ Série não são só três anos; tem o pré também.

P2 -É, mais eu comecei mesmo a ler e a escrever...Na primeira passa direto, então o primeiro não conta.

Pesquisadora - Você mora com quem?

P2 - Eu?

Pesquisadora-É.

P2 - Com ninguém. 
Pesquisadora - Com ninguém? Mora na rua?

P2 - Aham! Num castelo eu moro.

Pesquisadora - Faz quanto tempo?

P2 - Num castelo.

Pesquisadora - Onde?

P2 - Num castelo.

Pesquisadora - Num castelo?!

P2 - É.

Pesquisadora - Como é o seu castelo?

P2 - Eu estou brincando. Ontem eu falei assim, zoando, mas é um castelo. É uma forma de... Sabe? Não sei expressar agora não.

Pesquisadora - Mas é legal você falar que mora em um castelo. Achei bacana. Você mora na rua há quanto tempo?

P2 - Oito.

Pesquisadora - Oito anos? E você... Você ainda usa crack ou já parou de usar?

P2 - Uso, de vez em quando.

Pesquisadora - De vez em quando. E não foi a sua primeira droga.

P2 - Não.

Pesquisadora - Não? Qual foi a sua primeira droga?

P2 - O cigarro.

Pesquisadora - Cigarro? E quantas vezes...? Você já está aqui no PROAD há quanto tempo?

P2 - Um ano e meio.

Pesquisadora - Um ano e meio? E por que você resolveu vir se tratar?

P2 - Sinceramente eu não vim me tratar, assim "resolver vir tratar". Resolvi conhecer pessoas diferentes de onde eu estava convivendo.

Pesquisadora - Entendi.

P2 - Que eu já fiquei aqui onze meses sem usar crack.

Pesquisadora - E você não tem vontade de parar?

P2 - Acho que todo o mundo tem.

Pesquisadora - É? E por que você tem vontade de parar?

P2 - Porque não é um negócio bom. Não tem lucro nenhum isso aí.

Pesquisadora - Mas por que não é bom? Não é bom quando a gente usa? 
P2 - Não, porque isso aí que tá causando a droga, é isso aí, você vê aí no mundão aí o que a droga faz... Droga não traz felicidade na vida de ninguém. Não existe felicidade em droga. Pra mim, pelo menos no meu ponto de vista... Acho que todo o mundo tem vontade de parar, por que... Tá na cara, né, de tudo, né?

Pesquisadora - Entendi. Porque não traz nada de positivo.

P2 - É. Destrói. Só destrói. Só destruição. Entre família, você. Decepção. Tudo.

Pesquisadora - E por que você começou a usar? Lá atrás.

P2 - Embalo.

Pesquisadora - Embalo?

P2 - É. Sei lá... Já era mais acelerado também. Ah, comecei a usar em embalos, com o pessoal conhecido.

Pesquisadora - Você tinha quantos anos?

P2 - Onze.

Pesquisadora - E aí os amigos usavam...

P2 - É. Eu passei pra coisas mais pesada. O que eu calculo foi a maconha, fumei cigarro por... sozinho. Comecei usar sozinho.

Pesquisadora - Sozinho? Foi comprar?

P2 - É. Não, aprendi a tragar com uma pessoa.

Pesquisadora - E resolveu experimentar?

P2 - Aí essa pessoa, amiga de infância, ela me ensinando a tragar, tentando me ensinar a tragar... (risos)

Pesquisadora - Como é que foi que você aprendeu a tragar? Qual é a dica?

P2 - Ah, não vou te ensinar. Eu não ensino pra ninguém. Vou ensinar a...?

Pesquisadora - Mas eu sei! Já me ensinaram! Sabe como é que é?

P2 - Mas eu não vou te ensinar.

Pesquisadora - Não. Mas eu posso te falar como é que me ensinaram?

$\mathbf{P 2}-$ Hum?

Pesquisadora - Me ensinaram que era assim: você tem que puxar e aí você faz (som de aspirar). E aí você faz: “Ai! Chegou alguém!”.

P2 - Nossa!

Pesquisadora - Pois é. Foi o que me falaram. (risos)

P2 - Ah, não, não aprendi assim. (risos)

Pesquisadora - A sua dica não foi essa? 
P2 - Não. A minha dica não foi essa não. Ah, me ensinou: "puxa assim e faz assim". Pronto. Pesquisadora - E aí você foi indo. Foi no cigarro, começou a beber, maconha e aí foi tudo junto?

P2 - Ah, beber eu vim beber mais na rua.

Pesquisadora - Entendi. Depois que veio morar na rua... E você decidiu morar na rua por quê?

P2 - Briga de rua.

Pesquisadora - Briga de rua? Como assim.

P2 - Eu não decidi,foi... Ah, briga de rua. Agora sinceramente tô morando na rua porque eu tô... Porque eu sou meio cabeça-dura, burro pra caramba! Vamos dizer assim. Não é bem assim, mas foi a palavra que eu encontrei mais rápido que eu não tô a fim de me expressar muito. É. Saí de casa, vim morar na rua porque... Acho que estou mole, né?

Pesquisadora - Tá o quê?

P2 - Acho que estou mole.

Pesquisadora - Mole? Como mole? Não entendi.

P2 - Ah, eu estou desanimado, sei lá. Acho que é tanta coisa que aprendi morando na rua. Gosto pra trabalhar eu sempre tive, mas então não vou procurar; dinheiro eu arrumo. Droga eu não arrumo não, que eu não peço dinheiro. Eu não só tenho visão pra droga. Minha mente não tá fechada. Graças a Deus até o momento não, não está fechada. Não só tenho visão pra a droga, então... Dinheiro eu arrumo pra pagar aluguel, isso aquilo outro. Trabalho tem por aí, é o que não falta em São Paulo, então é mais burrice minha. Sei lá... Uma falta de... Um incentivo...

Pesquisadora - Mas por que burrice? Você não gosta?

P2 - Não é burrice. Não é questão de burrice assim, sabe? Acho que eu tô desanimado, um pouco.

Pesquisadora - Entendi.

P2 - Tô sem autoestima.

Pesquisadora - Entendi. E alguma vez você já se sentiu... Já se sentiu assim, diferente das pessoas que não usam droga, por usar droga?

P2 - Se já senti diferente?

Pesquisadora - Diferente das outras pessoas, assim, você já se sentiu... "Pôxa, eu sou diferente. Alguém me olha diferente".

P2 - Não, isso aí é óbvio que muita gente olha, né? 
Pesquisadora - Por que óbvio?

P2 - Porque isso existe, principalmente em sociedade, um monte de gente. Você usa droga todo o mundo vai te olhar torto. E às vezes a pessoa que te olha torto, é bem pior que você. Pesquisadora - Concordo. Fala mais sobre isso. Como assim? Você já teve alguma situação que alguém te olhou torto?

P2 - Várias.

Pesquisadora - Qual foi uma?

P2 - Uma?

Pesquisadora - Uma ou duas. Ou quantas você quiser. Conta as mais legais.

P2 - Eu já tive várias, mas não me lembro de nenhuma assim atualmente. Tenho uma que agora nem tentei lembrar ainda, né? Que eu tentar lembrar de uma...

Pesquisadora - Quer bala?

P2 - Fica à vontade.

Pesquisadora - Obrigada.

P2 - (risos)

Pesquisadora - Estou deixando você lembrar de alguma situação.

P2 - Ah, me olhar torto, tem gente que eu nem sei. Tanta gente que nunca vi na vida me olha torto. Têm uns que é legal, tem uns que não é... Têm uns que olha torto, tem outros que não. Tem uns que acha que é feito de ouro!

Pesquisadora - Feito de ouro!

Pesquisadora - Mas você acha que as pessoas olham mais torto por quê? Assim, por causa da droga mesmo?

P2 - Têm uns por causa do medo. Têm outras que...

Pesquisadora - Medo do quê?

P2 - Medo do quê? De a pessoa roubar ela, sei lá... Umas olham... Têm várias coisas. Gente olha com medo. Tem gente que olha com medo, tem gente que te olha tipo discriminando. Têm vários tipos de olhar, né? Eu acho assim que... Têm vários tipos de olhar. Tem gente que te olha como ser humano. Nem todo mundo pensa do mesmo jeito. Têm vários pensamentos. Eu não sei o que passa na mente das pessoas. Só pelo olhar, o olhar já tem... Olhando no olhar meio estranho, assim, você já vê se a pessoa... Você sabe se tá passando na mente dela, se ela tá com medo, se ela está discriminando, já têm uns que já dá pra você vê se tá discriminando ou não. Muitas... Têm vários tipos de resposta pra cada olhar.

Pesquisadora - Entendi. 
P2 - E às vezes que tem olhar que você não sabe nem a resposta. Vixe! Tanta coisa.

Pesquisadora - Nem vale a pena pensar às vezes, não é?

P2 - É. Também.

Pesquisadora - E você já teve... Eu sei porque você já me contou, mas eu vou perguntar por causa do roteiro. Você já teve algum problema com a polícia relacionado com drogas? De a polícia te abordar, te parar?

P2 - Já.

Pesquisadora - Já? E como foi?

P2 - Umas foi legal, outras foi... Uns é legal, outros é chato.

Pesquisadora - Você acha que a maioria é legal ou a maioria é chata?

P2 - Uns é bom, outros é ruim...Bom, pelo menos por onde passei na minha vida, aqui na rua, pelo fato do lugar onde eu convivia, a maioria depois que conheceu o meu dia-a-dia, como eu não sou de aprontar muito... Não tô falando que sou santo, mas naonde (sic) eu convivia, aqui nessa região, nessa região... Pelo fato de eu ser uma pessoa sossegada, em termos, eu nunca transei ninguém assim... Por isso a polícia nem embaça na rua. A polícia que eu conheço nem embaça.

Pesquisadora - E os que não conhece?

P2 - Mas têm uns que... Têm os folgado já que fazia uma pergunta, eu já respondia na boa e ele... Toda pergunta que ele... Ele fazia uma pergunta e toda resposta que eu dava, nossa! Ele parecia que ele queria me bater!

Pesquisadora - E já te bateram?

P2 - Já.

Pesquisadora - E foi por causa de droga ou não?

P2 - Não. Não, já vêm... Essa pessoa que tô falando aí, esse polícia que nunca vi na vida, ele tava com um colega, acho que ele tava querendo mostrar serviço... Mostrar serviço lá pra o colega dele, não sei. Ele fazia a pergunta, eu respondia e eu não tava nem..., não tinha usado nada e ele fazia uma pergunta, eu respondia e ele... Falava um monte pra mim. Falava um monte... Outros é legal. Têm uns legal, tem uns ruim. Tem todo tipo nesse mundo. (risos) Pesquisadora - Mas você pode me dizer se você tem medo da polícia?

P2 - Se eu tenho medo?

Pesquisadora - Do que eles podem fazer.

P2 - Ah, a senhora mexeu no meio de tanta coisa... Que eu não tinha...

Pesquisadora - O que é que eu mexi? 
P2 - Tem hora que eu não tenho medo de nada, tem hora que tenho medo de tudo; tem hora que eu tenho medo até de viver. Já senti até... Mas já senti esse negócio: medo de viver e morrer ao mesmo tempo, ô! (risos) Eu tava ficando louco!

Pesquisadora - Me conta disso?

P2 - Isso é um negócio psicológico, né? Nossa! é uma loucura! Eu falei: “Meu Deus! eu... Nossa, eu tô mal mesmo", viu?

Pesquisadora - Ao mesmo tempo?

P2 - Ao mesmo tempo! Ao mesmo tempo, né? Nossa! ao mesmo tempo assim. Falei: "Nossa! Medo de viver e medo de morrer ao mesmo tempo", assim. Parecia que dá um pânico ni mim (sic).

Pesquisadora - Então têm vezes que tem medo da polícia e vezes que você não tem?

P2 - Ah, não. Têm vezes que eu tô nem aí pra nada. Tem vez que tô aí pra tudo. Tem vez que não tenho medo de nada. Tem vez que eu tenho medo de tudo. De tudo. De coisas que nem existe às vezes. Às vezes existe, já existe, mas...Eu acabo, sei lá, pensando que poderia acontecer comigo. Tanta coisa que acontece no mundo que eu falo: "Meu Deus! Tanta coisa que acontece no mundo e eu... "Sabe? Falando... "Será que eu sou o próximo?” Tem hora que bate aquele tiotêna mente. Nem sempre. Raramente.

Pesquisadora - Entendi.

P2 - Tanta coisa.

Pesquisadora - Mas alguma vez que você estivesse mal, assim, por causa de droga, que você estivesse pensando "poxa eu quero parar", pensando em procurar ajuda... Você já deixou de procurar ajuda quando de repente tem medo de ser preso, assim, porque estava com droga?

P2 - Procurar ajuda o quê? No memento de uso?

Pesquisadora - É.

P2 - Naquele momento de uso? Naquele momento de uso que tô usando?

Pesquisadora - Ou não quando você está usando, mas uma hora você tem um pensamento: "poxa, acho que eu preciso de ajuda".

P2 - Ah, isso aí, fia, nossa! Isso aí é certeza na minha vida. Preciso de tanta ajuda na minha vida. Vixe! Ajuda... Mental então... Mentalmente,na minha mente.

Pesquisadora - Mas você já teve medo de procurar essa ajuda? Por pensar: "Nossa! podem fazer alguma coisa comigo". Não?

P2 - Nunca. Isso não existe, pra mim não. Medo de procurar ajuda não existe. Pra mim... 
Pesquisadora - E você já pensou em procurar ajuda? Quando você falou: "Poxa, usar droga é proibido, então acho que é melhor eu me tratar". Você pensou em procurar ajuda por outros motivos?

P2 - Não. Não procurei porque droga é proibido. Mesmo que ela fosse liberada. (risos). Mesmo que ela fosse liberada. Não deixa de ser uma droga um negócio que causa danos ao ser humano, como cigarro, bebida, tudo ferra a vida do ser humano. Só que tá aí. Têm famílias sendo destruída por vício, por bebida, isso e por aquilo outro. Tem mundo está vendo, que não tá nem vendo, tá nem aí. Que tem muita gente que tá querendo ajudar, e não pode, que quer... Tem gente que quer ajudar e não pode, não ajuda.

Pesquisadora - Quem é?

P2 - Tem gente que quer ajudar e não pode.

Pesquisadora - Quem pode ajudar e não ajuda?

P2 - Não sei. Mas com certeza tem essa pessoa. Existe essa pessoa no meio de muitas.

Pesquisadora - Entendi.

P2 - Têm muitas pessoas que querem ajudar e não ajudam. Às vezes, a pessoa mesmo não pode..., às vezes uma pessoa que você nem..., nunca falou nada, mas você vê que a pessoa ela quer ajudar e não pode abrir uma palavra, né, por que..., não pode abrir a boca para dar uma palavra, assim, quer colocar... Ela está vendo tudo o que está acontecendo com ela; ela já tá fazendo o serviço dela - tá vendo tudo, quem é corrupto, quem não é. Seja lá nos engravatado lá que tá no poder lá, seja aqui, assim, em todo lado. Nossa! maldade tem todo lado. Maldade você... Nossa! Você nunca sabe... Maldade nesse mundo aí, nossa! de todos os lado.

Pesquisadora - E você sente que as pessoas se importam com você, ou você acha que a maioria não está nem aí?

P2 - Ah, sinceramente não sem nem distinguir mais quem é certo, quem é errado; quem tá errado e quem tá certo. (risos)

Pesquisadora - Já perdeu?

P2 - É. Tô perdidão. Nossa! Tô, eu tô perdidão. Eu tô perdidão! Tô perdidão! Perdidão, assim, em termos, porque, nossa! muita cosia pra uma mente só.

Pesquisadora - A cabeça pensa muito, não é?

P2 - Ham?

Pesquisadora - Sua cabeça pensa muito? 
P2 - Tem cada coisa. Ah, pensa, né? Pensa e não faz nada. Já fiz muita burrice na minha vida. Já fiz burrice pra caramba, mas... Sei lá. Impulso. Ah, tanta coisa! Eu já ajudei tanta pessoa já. Querendo ajudar tanta pessoa. O pouco que eu tenho... Não tenho nada, mas... Pesquisadora - E alguém já veio te ajudar?

P2 - Já. Tentaram. Bom... Ah, tem. Na rua mesmo, assim, é difícil assim... É difícil não, mas por onde eu andei, assim...

Pesquisadora - Quem que chega perto só para atrapalhar?

P2 - Ah?

Pesquisadora - Quem chega perto, chega só para atrapalhar? De repente ajuda?

P2 - Não. Sempre tem quem ajuda. Tem gente que atrasa... Tem gente que tenta ajudar e não consegue, por mais que não se foca tanto, e não consegue. Tem uns que... Às vezes a gente tá te ajudando, você acha que não tá te ajudando. Sei lá... Às vezes você quer uma ajuda a mais e... Nossa! Sabe? É tanta coisa que a gente pensa... A mente assim vai tão além!

Pesquisadora - E o que você acha que poderia te ajudar a parar de usar? A, sei lá, de repente sair da rua? Você pensa em alguma coisa, assim: poxa, se acontecesse isso...?

P2 - Acho que arrumar um serviço em primeiro lugar. Um serviço. Focar um pouco. Esquecer o que eu passei na rua um pouco, pouco a pouco. Lembrar do... Ah, lembrar de quando era uma pessoa que tinha uma casa, né? Não por que eu saí, eu vi pra rua, eu pensei já diferente. Mas fui lá. Fui lutando. Porque é tanta coisa. Saudades, solidão, mágoa. Nossa! É tanta coisa. Ah, quem me podia ajudar que é a minha mãe, minha mãe não pode. E eu podia ajudar ela e também e não ajudo.

Pesquisadora - Talvez a droga (ininteligível - 00:20:59).

P2 - Porque eu acho que eu já tentei ajudar ela. Eu já tentei ajudar ela, mas é... Nunca a mãe... Fez por mim, pela própria, pela minha mãe, pelo o que ela fez por mim, pelo meu irmão, não foi nada o que eu fiz por ela até agora. Acho que ela tá totalmente dependente de uma ajuda.

Pesquisadora - E você se sente mal por não ajudá-la?

P2 - É... Já me senti muito já. Não sei se vai bater a realidade, amanhã. Deus me guarde, depois que ela for embora, que ela morrer. Não sei qual vai ser o baque depois disso. Que antes, antes eu já tive tanto baque, porque praticamente pra mim ela morreu. Assim, em termos, assim eu acho em termos. Não é que ela morreu. Acho até duro falar assim dela, porque ela tá viva. Mas, sei lá, ela tem Alzheimer e eu... E quando ela tinha uma mente boa, 
assim, antes de eu vir pra a rua, ela tinha uma mente boa, dava pra conversar. Eu era maior, maior pessoa sem noção das coisas, de muitas coisas.

Pesquisadora - Ela ficou antes de você ir para a rua?

P2 - Depois eu vim que ela piorou.

Pesquisadora - Mas ela já estava antes?

P2 - Não. Nem tanto, ela conversava. Tava da hora ela. Tava totalmente independente ainda. Depois que eu vim pra rua. Pouco a pouco... Assim. Depois que eu saí de casa. Acho que... Inclusive eu falava pra ela: não, eu tô bem, tô na casa de um colega e tal. Mas só a minha ausência, entendeu? Que eu era o queridinho dela(risos). Ela é... Ela gosta do meu irmão também; o meu irmão é mais velho e tal, mas ela... Eu era o queridinho dela sim. Com certeza a mãe gosta dos dois, mas... Foi um baque pra ela. Um choque.

Pesquisadora - Você ter saído. Então você sente falta da tua casa?

P2 - Quem é que não sente?

Pesquisadora - E você acha que... Porque eu fico pensando, você não... Às vezes você não acha que a droga ou o álcool, ou qualquer coisa, ajuda um pouco a... a essa saudade não doer tanto?

P2 - Droga e álcool não ajuda em nada.

Pesquisadora - Mas então por que você usa se não ajuda em nada?

P2 - Bom, ajuda a destruir então. Nada, até minto, ajuda a destruir mais e mais. Pode fazer assim: você criar um mundo de ilusão; você achar que... Você sair da realidade pra ilusão, só se for. É a única coisa. Porque não dá... Ninguém nasceu usando droga!

Pesquisadora - Mas às vezes a gente não quer sair da realidade? Porque a realidade é doída demais?

P2 - Eu nunca pensei assim.

Pesquisadora - Não?

P2 - Eu não. Porque a realidade pra mim vai ser uma só. Seja você louco ou sóbrio. Duas, né? A realidade de você tá sóbria é você tá sóbria, vendo o mundo do crime, sóbrio. E a realidade de você tá louca, não deixa de ser uma realidade, você tá vendo o mundo louco, você tá chapadona. Você tá ali vivendo uma realidade, pode ser uma realidade cruel. Ter uma realidade, não é? É mais cruel. Acho que a realidade, você sóbrio, sem álcool, sem nada, então é uma realidade que pode ter uma realidade cruel, mas às vezes com álcool torna mais, bem mais cruel, assim, uma realidade bem mais cruel, entendeu? Mas não deixa de ser uma realidade. 
Pesquisadora - Por que será que é tão difícil parar então?

P2 - Por que será que é tão difícil parar? Acho que tem a maioria... Acho que tem muita gente... Acho que tá... Ah, tem muita gente nessa situação do álcool, não é, meu? E às vezes essa pessoa, sem querer - não que ela quer - sem querer o álcool tá influenciando ainda as pessoa até hoje, no meu ponto de vista.

Pesquisadora - Você acha que é mais fácil parar de usar crack ou parar de usar álcool? Você, para você. Se você pensasse hoje: "já, eu quero parar de usar alguma coisa”, o que ia ser mais fácil de ficar sem?

P2 - Bom, seu eu, no meu ponto de vista, até o momento, hoje, até hoje onde eu me encontro, pra pedra então, eu me seguro. Porque não tô nem embalado aqui pra usar crack. O álcool eu acho um pouco difícil; e eu vim pra a rua e não bebia. Eu bebia pouquinho. Eu bebia pouquinho, assim, raramente eu bebia, por que... Eu não tenho vício de bebida. Eu não tenho ainda, assim. Eu tô tendo, agora sim. Tô começando, mas não sou aquele viciado mesmo; tô na porta, tô começando a beber. Se eu for beber, é lá para 5 h da tarde, $6 \mathrm{~h}$; dependendo do dia e do momento. Que nem essa chuva aí (risos)...

Pesquisadora - Doído, hein?

P2 - E eu todo molhado! (risos)

Pesquisadora - Nossa, que sono! Nossa! Eu fico olhando para fora e me dá sono...

P2 - Doído por quê? Mas por que que a chuva tá doída?

Pesquisadora - Porque me dá sono.

P2 - Não tá bom? É doído isso aí?

Pesquisadora - Ah, eu tenho sono. Eu devo ter a doença do sono, de tanto sono que eu sinto.

Meu olho começa a fechar assim. Juro!

P2 - Não precisa jurar.

Pesquisadora - Você acredita?

P2 - Não desacredito também.

Pesquisadora - Mas não acredita.

P2 - É. Sinceramente não. Assim, ainda não...

Pesquisadora - Você não acredita em nada que eu te falo? Assim...

P2 - Ah, é difícil.

Pesquisadora - Desconfiado, né?

P2 - É.

Pesquisadora - Eu sou também. Quando é seu aniversário? 
P2 - Dezembro.

Pesquisadora - Dezembro? Você é sagitariano?

P2 - Dia 11.

Pesquisadora - Signo muito legal, sabia? Sagitariano é metade gente e metade animal.

Então ele tem a força do animal, a racionalidade do ser humano e a flecha dele aponta para o plano espiritual.

P2 - É? Não sabia não.

Pesquisadora - Legal, não é?

P2 - Bom. Não parei pra tentar entender isso agora ainda assim.

Pesquisadora - São três mundos: o bicho forte, o humano que pensa e o espiritual: Deus e as outras coisas.

P2 - Tá.

Pesquisadora - Então ele é o signo que, em tese, une todas as coisas. Completo. Responsa, hein?

P2 - Você lê aqueles negócio de signo?

Pesquisadora - Eu leio às vezes. Eu sou menina, menina gosta de signo.

P2 - Não gosta não?

Pesquisadora - Gosto! Menina gosta. As mulheres gostam mais que homem.

P2 - Aí, né? Nunca tinha reparado pra reparar isso daí não (risos).Estou desligado, desatualizado disso aí.

Pesquisadora - (ininteligível - 00:27:13) explicações.

P2 - O signo eu quero aprender e por que para uns dá certo e para outros não?

Pesquisadora - Então.

P2 - Suposição. Pode ser dois de sagitário. Suposição: tá nós dois sagitário, uma hora fala um negócio aqui pra mim, que é cabível e pra você não. Ah, não tem nada a ver comigo não...

Pesquisadora - Bom, eu não sei explicar.

P2 - Então, eu sei. Por que... A explicação é que isso é besteira(risos).

Pesquisadora - Você é desconfiado.

P2 - Bom, então, assim, pra mim é besteira, porque nunca me informaram, assim muito, conversar muito, daí soube porque... Pode ter uma pessoa que converse, saiba explicar mais como é o signo, como é..., as palavras que falam, não é? Mas não assim, pode ser a pessoa que (ininteligível - 00:27:51) que vem falar pra mim... Se eu não achar que devo colocar na 
mente, mas se eu achar que eu tenho que acreditar, eu acredito; se eu achar que não tenho que acreditar, aí eu falo: "não, isso é besteira". Entendeu? Cada um pensa do jeito que acha, tipo... Ah, você acha que é besteira, mas tem. Que nem fala muito às vezes dá bíblia pras pessoas, as pessoas acham que é besteira. Beleza! Fazer o quê? Não é? Então... Mas o tempo vai dizendo as coisas. Vai passando o tempo, né? Ah, sei lá. Não dá pra prevê o destino dos outros, cada um, assim; o que passa na mente das pessoas, né? Mas eu... Tudo o que eu falar de bom, assim, espero que um dia lá na frente, por mais que ela seja quase velha, um dia ela veja aquilo e entre nela; que ela vai, pode crer: “acordei, tarde, mas acordei!"(risos).

Pesquisadora - Sempre é hora de acordar, né?

P2-É.

Pesquisadora - Eu acho também. É isso.

P2 - Só isso?

Pesquisadora - Doeu?

P2 - Não. (risos)

Pesquisadora - Então pronto.Está com vergonha?

P2 - Eu? Nem um pouco. (risos)

Pesquisadora - Tem mais alguma coisa que você queira falar?

P2 - Eu não sei, a não ser que você tem mais alguma coisa pra mim perguntar...

Pesquisadora - Não, mas se você quer falar alguma coisa. Pensa alguma coisa muito legal. P2 - É porque ás vezes é assim, eu... Às vezes... Eu saio daqui e começam a vir um monte de coisas na mente. Um monte de coisas interessantes.

Pesquisadora - Você me fala, que aí a gente grava de novo.

P2 - Vem um monte de coisas interessantes.

Pesquisadora - Se você pensar....

P2 - Às vezes eu quero falar e esqueço tudo! Na hora H esqueço tudo, depois eu lembro...

Pesquisadora - É. É fato. E por isso que o povo faz prova e não lembra.

P2 - Eu lembro das coisas...

Pesquisadora - Mas se você lembrar algum dia uma coisa legal, você me fala? Aí a gente grava. Eu edito. Boto junto.

P2 - Não garanto.

Pesquisadora - Que medo é esse de falar com os outros?

P2 - Não é medo assim... Ah, vou falar, vou chamar... É mais fácil te mandar mensagem por aqui, ô! Ah, me lembrei de um negócio, tu-tu-tu, mandomensagem pra você. 
Pesquisadora - É que tem que ser na hora?

P2 - Ah, é. Tenho muitas coisa... Sozinho, meu, no mundão! Imagina, eu na chuva, onde eu vou dormir? Se eu quiser pagar um hotel agora, eu tenho dinheiro. Graças a Deus eu tenho dinheiro. Graças a Deus eu tenho um pouquinho de dinheiro pra mim pagar (sic) hotel, R\$ 130,00 dá pra pagar um hotel, não dá?

Pesquisadora - Opa, se dá.

P2 - Então...

Pesquisadora - Até dois, não é?

P2 - É. Aí... Eu sou... Nossa! Eu sou assim, quer dizer, eu sou assim. Um tempo assim..., teve uma vez o tempo assim, eu assim: "não vou pagar hotel. Não vou pagar, não vou dormir em hotel". Porque nem sempre com tempo assim eu fico "pago hotel". Sou mais comprar aquela barraca de acampamento que é barata, $\mathrm{R} \$ 50,00$ alguma coisa tipo, fico de boa. Oxe, da hora! Mas aí... Já aprendi a me virar, sabe? Sempre arrumo um cantinho. Já paguei (ininteligível) na rua assim, até hoje eu pago, burrice minha, porque já aprendi a me virar, aprendi. Financeiramente na rua eu já aprendi. Financeiramente, em termos. Aprendi a me virar. A parte de comida também eu não pago, já aprendi a me virar também. Já apanhei no começo, assim, um pouco, sofri um pouquinho. Sofri em termos, também. Mas apanhei um pouquinho. Aí aprendi a me virar já. Mas então, como tava falando, com um tempo assim... Há um tempo assim, mas essa garoa, essa chuva que não parava e eu com dinheiro; "não vou dormir em hotel, não vou; que? não vou não".

Pesquisadora - Por que não?

P2 - "Já paguei (ininteligível - 00:30:55) tantos anos, por que mais um? Não vou não. Não vou dormir não". Ai beleza. Aí ficava um tempo, uma semana toda assim e tal, e eu com dinheiro guardado... Não que sempre eu guardo dinheiro, mas nessa época eu tinha dinheiro guardado. Aí parou a chuva, parou tudo, o tempo melhorou, à noite fez calor, não tava chovendo, estrela não céu e tudo, e eu fui dormir no hotel! (risos) Aí eu falava: "Ai, que bom! Que louco que eu sou! Maior chuva, maior pé d'água e eu falei: não vou, não vou, não vou”! Tipo de pirraça comigo mesmo. Sei lá.

Pesquisadora - Você briga com você mesmo?

P2 - É. Entendeu? Um atrito comigo mesmo. Coisa de durão, sei lá. Sabe? Aí depois fico pensando: "Caramba! Paguei a maior merda essa semana. Não quis ir no hotel, agora..."

Pesquisadora - Agora que está sol... 
P2 - Agora que está fazendo um ar lindo, no meio da rua, vou querer dormir no hotel. Que loucura!

Pesquisadora - O que você acha que é o mais difícil de morar na rua, de tudo?

P2 - Saudade.

Pesquisadora - Saudade do quê?

P2 - Ah, de tudo. De tudo. Das coisas boas.

Pesquisadora - E quais são as coisas boas?

P2 - Minha mãe. Quando eu ficava com a minha mãe, que eu morava com a minha mãe, meu pai...

Pesquisadora - E o seu pai?

P2 - Meu pai? Tá lá. Nunca mais eu vi.

Pesquisadora - Não?

P2 - Não.

Pesquisadora - Você não fala com ele?

P2 - Falo. Já aprendi a gostar mais dele quando vim pra rua.

Pesquisadora - Aprendeu a gostar mais? Você não gostava dele antes?

P2 - Muito não.

Pesquisadora - Por que não?

P2 - Não era muito chegado. Porque ele batia na minha mãe quando eu era pequeno. Por nada. De graça. Sabe de graça? Ele tem problema mental também. Eu até entendo isso, entendeu?

Pesquisadora - Mas ele tem mesmo?

P2 - Tem! Para ele todo o mundo é amigo.

Pesquisadora - Amigo?

P2 - Ele é analfabeto, mas é uma pessoa...Ele tem problema mental, assim, mas eu acho que se eu comparar ele hoje, eu vou olhar para ele hoje assim, que quem tem mais problemas é que que ele (risos); acho que sou o que tem mais problema mental. Não é problema mental assim, que eu tô, mas... Acho que por mais que ele tenha os problemas mental dele, é sempre as coisas mais certas, entendeu? Mas não tanto...

Pesquisadora - Então, mas o que para você é certo?

P2 - Não que ele fez as coisas mais certas. Não tô sabendo explicar direito, assim, agora. Vou falar assim... Tipo..., vou falar..., tipo, fora disso, já a mesma coisa, de falar o que eu tava tentando concluir... Eu não gostava dele muito porque ele batia muito na minha mãe, 
por nada, de graça. Ele tinha até problema mental, pra ele todo o mundo é amigo... Eu conheço... Pelo menos, da última vez que eu vi era assim, era todo mundo amigo. Ele conhece o cara hoje, no bar, começa a jogar sinuca com o cara: é meu amigo, e meu amigo... O cara falava bonito com ele, rapidinho - era 171 - e ele "meu amigo, meu amigo, meu amigo". Mas, fora isso, era... Ah, ele zuava, ele batia na minha mãe, de graça, por nada. Quando chegava do serviço ele batia na minha mãe. Eu tinha que separara lá. Tirar ele da minha mãe...

Pesquisadora - E você era novinho?

P2 - Era! Tinha seis, sete anos de idade. Uns seis, sete anos, cinco... Várias vezes. Meu irmão.

Pesquisadora - Mas depois que você foi para a rua, você sentiu saudades?

P2 - Aí eu peguei, comecei a fumar maconha. A gente fumava cigarro dentro de casa. Chegava bêbado às vezes, bêbado. Quando chegava bêbado, eu não tinha medo dele (risos). Eu perdi o medo dele quando ele chegava bêbado, caindo. Ele sempre foi aposentado, sempre aposentado, mas...

Pesquisadora - Mas quando ele estava bêbado, ele ficava menos agressivo?

P2 - Não! Ele ficava... Fisicamente ele ficava menos agressivo. Não tinha como, né? Fisicamente até eu batia nele. (risos)

Pesquisadora - Entendi.

P2 - Quando ele estava bêbado de cair, sabe? Agora... Quando ele ficava bêbado; aliás, quando nem tava totalmente bêbado, sem... Tenho poucas palavras disso aí agora e também não tô a fim de lembrar muito esse momento agora não. Mas ele batia na minha mãe de graça muitas das vezes. Não estava nem caindo, nem nada. De graça! De graça! Até que eu comecei... Eu fumei cigarro... Eu aprendi a fumar cigarro por ver lá só na rua, ele já fumava dentro de casa. Lembro até disso, que eu falava: "Pai, fuma dentro do quarto que eu vou acabar fumando. Você vai ver, eu vou fumar!”. E aí... Acabei fumando.

Pesquisadora - Mas hoje em dia você se dá melhor com ele?

P2 - Nunca mais vi ele, oito anos e meio.

Pesquisadora - Você nunca mais viu depois que você saiu? Mas você sabe onde ele está, como encontrar?

P2 - Sei. Ele está lá na casa dele. Meu irmão está morando lá... Mora ele lá.

Pesquisadora - Ah, seu irmão mora com ele? E o seu irmão, você encontra?

$\mathbf{P 2}$ - É. Ele mora na mesma casa, mas é separado. 
Pesquisadora - Você encontra o seu irmão?

P2 - Se eu o quê?

Pesquisadora - Você encontra?

P2 - Não. Não me bato com ele não.

Pesquisadora - E por que não?

P2 - Ah, já não me batia muito. Agora não me bato com parente, com ninguém. Só o meu pai e a minha mãe mesmo. Quem poderia imaginar! Minha mãe... Meu pai às vezes, faz oito anos e meio que eu não vejo ele. Olha que calça que eu arrumei, suja... Tá feia a coisa.

Pesquisadora - $\mathrm{O}$ quê?

P2 - A calça que eu arrumei. Olha que bagulho feio da porra!

Pesquisadora - Está na moda.

P2 - É moda? Eu odeio essa moda. É um bagulho feio (risos). Mas eu não gosto. E mesmo assim, aqui não tá na moda, aqui tá sujo de lama, aqui o negócio tá na cara aqui... Vão falar que tá relaxado mesmo! (risos).

Pesquisadora - Está na moda aquelas que são curtas.

P2 - Eu não gosto.

Pesquisadora - Você já viu?

P2 - Já. Não gosto. Então... Aí eu já não... Aprende muito coisa na rua.

Pesquisadora - Mas você acha que você saiu de casa porque você estava..., você fícava triste em casa?

P2 - "Eu saí de casa" o quê?

Pesquisadora - Saiu de casa para morar na rua?

P2 - Ah! Briga de rua. Isso aí eu não vou falar, assim... Não vou falar isso não. Briga de rua. Pesquisadora - É que eu não entendo como é que não... Não precisa falar com quem foi. Mas me explica assim, para quem não entende. Você briga na rua e aí você tem que sair? P2 - Não é briga na rua. É briga de rua. Porque se fosse uma briga de casa, você voltaria para casa. Se fosse uma briga de pai e mãe, dava pra voltar.

Pesquisadora - Dá?

P2 - Entendeu?

Pesquisadora - Ah, briga com a sua vizinhança, assim, mais ou menos?

P2 - Ah, eu te falaria tudo agora se você não estivesse gravando a minha voz, você sabe?

Pesquisadora - Mas eu não vou falar quem é você!

P2 - Independente. Mas não... 
Pesquisadora - Você quer que eu desligue, eu desligo.

P2 - Não (risos) Não precisa desligar. Você que sabe, se você quiser desligar...

Pesquisadora - O que eu queria entender... Por que... O que eu imaginei, fala se eu estou certa. Se fosse uma briga de casa você poderia voltar. Então uma briga de rua significa que você deve ter brigado com alguém no seu bairro, com um grupo e você não pode mais voltar para casa.

P2 - Mas não foi briga fisicamente. Foi um desacerto que aconteceu na minha vida, entendeu? Um desacerto. Não foi fisicamente. Foi materialmente, vamos dizer que foi materialmente.

Pesquisadora - Tá. É negócio de droga?

P2 - Teve.

Pesquisadora - Entendi.

P2 - Entendeu?

Pesquisadora - Como se você ficasse devendo?

P2 - É. Bem por aí. É, fiquei ainda três dias lá e ainda senti maldade. Eu errei? Eu errei, mas eu assumo o meu erro. Falo comigo assim, se sentir maldade...

Pesquisadora - E não dava pra acertar?

P2 - Ah, dava. Mas aí o dinheirinho? A minha parte eu acertei, mas aí rolou tanta coisa depois disso aí que eu...

Pesquisadora - Que coisa?

P2 - Foi outra pessoa.

Pesquisadora - Tá.

P2 - Trabalhava eu e outra pessoa. Aí nós vacilou, eu e essa outra pessoa vacilou, sinceramente nós vacilou, nós errou, mas... Que nós tivemos oportunidade - tinha errado uma vez, tive oportunidade, errou duas vezes e aí pronto, aí o negócio apertou.

Pesquisadora - E aí você...

P2 - Aí eu assumi ainda, ficou essa pessoa, acabou de ferrar tudo. Ainda agora tava ferrada, ela piorou tudo de vez. Foi embora com tudo, com tudo... Aí, Nossa! Falei: "fulano, onde tá?”. Falei: vou ver se tá em tal lugar. (risos)

Pesquisadora - Salvo sua pele?

P2 - É.

Pesquisadora - Você nunca mais viu esse fulano?

P2 - Eu não. Também nem me importo mais ver ele ou não. Já não é mais a mesma coisa... 
Pesquisadora - Por que você começou a trabalhar com isso?

P2 - Porque eu comecei andando com esse pessoal...

Pesquisadora - Você era novinho?

P2 - Não. Quando eu comecei a ver as coisas na quebrada assim não era novo. Quando comecei a ver as coisas na... Ah, eu vivia em um lugar onde tinha muita coisa, não é, meu? Muita morte, muitas coisas assim e eu fui vendo, desde pequeno, desde pequeno.

Pesquisadora - Morte perto de você?

P2 - Não. Houve uma... Pequenininho mesmo não, já vi vários corpos, porque, nossa! Eu era terrível. Pequeno, seis, sete anos de idade, eu andava aquele bairro todinho. Minha mãe ia trabalhar; meu pai às vezes ficava no bar, e eu escapava, ia para a rua, o quê? Meu irmão ia para a rua... o quê? Eu escapava, queria nem ficar em casa. Saia pela janela, aqueles vitrôzinhos que abria assim. Eu puxava a alavanquinha e puxava e abre e fecha. Ninguém me segurava. Eu era terrível. Aí eu saia, até que eu parei de sair pelos vitrôs, porque fiquei com a cabeça presa no vitrô.

Pesquisadora - Ah, você tentou sair no vitrô mesmo?

P2 - Eu saía, várias vezes.

Pesquisadora - Eu achei que você estava dando um exemplo.

P2 - Não! Eu saía várias vezes pelo vitrô, pelo vitrozinho...

Pesquisadora - Imagina atua mãe ir atrás de você!

P2 - Não! Ela estava trabalhando. Sempre que ela trabalhava. E aí eu fiquei preso lá. "Ah, eu vou com meu pai”. Ele no bar..., está todo o mundo fora e eu vou ficar preso em casa? Meu irmão jogando bola na rua; meu pai lá no bar; minha mãe trabalhando; eu lá dentro de casa sem televisão. Sem televisão? Eu... Nossa! Era na época dos Cavaleiros do Zodíaco, se não me engano.

Pesquisadora - Chegou a assistir, não é?

P2 - É. Então, eu doido para ver. Falava o quê? Maluco. Eu ia lá me ferrar, mano. Eu saía. Eu era terrível. Não tava nem aí. Eu saía. Já tinha um... Não sei se é por causa disso que eu era meio nervosinho assim... Sei lá..., às vezes por causa disso. Não sei se isso meinfluenciou...

Pesquisadora - Isso o quê?

P2 - Eu acho que influencia um pouco. Ei via meu pai bater na minha mãe, e eu cresci com isso, né, meu? "Para pai, para, para para"; segurava ele, tipo o homem da casa. A criança da casa praticamente sendo o homem da casa. Antes da adolescência, uma criança de sete anos, 
não é, uma criança, antes da adolescência, já sendo o homem da casa, que é mais que adolescência. Não homem, mais ou menos inteirado, vamos dizer assim.

Pesquisadora - E aí você começou a ver que [ininteligível] trabalhar e que fazer e ganhar [ininteligível]

P2 - Aí eu acho que foi... Sei lá... Eu acho que influenciou, acho que isso tem um pouco a ver, né, meu? Eu comecei assim... Não a ver com usar droga, mas o a ver de eu ser... Eu não sei se eu já era meio levadinho desde pequeno...

Pesquisadora - Mas você acha que não tem nada a ver com você usar droga?

P2 - O... Nossa! Já tô tendo um branco já na mente agora! Ah, o quê? Usar droga? Usar droga foi no embalo. Foi de embalo. Comecei a fumar cigarro e... Eu não parava em casa. Não parava quieto e... Minha mãe trabalhava, meu pai ficava nos bar bebendo, meu irmão ia pra jogar bola. Uma coisa que podia me segurar em casa era televisão, depois nem televisão me segurava mais em casa. E todo mundo tinha..., a maioria das pessoas tinha televisão, assistia e tal. Então eu não fui... Já andava na quebrada já o bairro inteirinho... O bairro era grande. Era muito grande o bairro lá no lugar aonde eu morava. Era muito grande. É muito grande. É muito grande.

Pesquisadora - Você acha que você começou a trabalhar mais porque você via as pessoas e via que elasestavam trabalhando e queria fazer parte da turma, ou queria ganhar dinheiro mesmo?

P2 - Ah, mais para fazer parte mesmo.

Pesquisadora - Dinheiro nem era tanto assim?

P2 - É. Adiantava assim, um pouco assim, mas era mais se achava, se achava. Maior...

Pesquisadora - Entendi. Tipo “da galera do mal”.

P2 - É. "Eu sou da galera". Não do mal, não era do mal. Mas era muitas coisas maus que rolava no meio. Não era todo mundo mau. Sempre tinha os maus e os bons.

Pesquisadora - Não, assim, eu falei na verdade, talvez eu tenha me expressado mal. Mas mais assim do pessoal que...

P2 - É. Do movimento. Ter conceito, né? "Tô ali e pá, ninguém mexe comigo". Ninguém mexe comigo. Não que "ninguém mexe comigo" assim, mas eu sempre fui uma pessoa sossegada.

Pesquisadora - Mas você tem uma moral.

P2-É..., é..., é... Isso aí.

Pesquisadora - É mais conceituado. 
P2 - Isso. Isso. É isso mesmo.

Pesquisadora - Daí teu amigo te passou a perna e você se lascou!

P2 - Tá me dando uma bronca! (risos)

Pesquisadora - E teve que, ó, picar a mula. Estou falando. Ninguém vai nem saber quem é teu amigo, quem é nada. Relaxa.

P2 - (risos). Tá bom. Eu não estou ligando muito para isso. Se não estivesse aqui também, minha voz eu tava soltando.

Pesquisadora - Claro, óbvio.

P2 - Porque o meu nome já está aí.

Pesquisadora - Não. Não.

P2 - Não, tá.

Pesquisadora - Tá aqui e aqui...

P2 - E aqui.

Pesquisadora - Mas comigo. Comigo. Esse áudio ninguém vai ter acesso. Só eu.

P2 - Por mim, pode ter quem quiser. Não estou falando nada demais.

Pesquisadora - Não. Mas eu estou me comprometendo...

P2 - Não, por mim... Não falei nada demais assim, pra mim tá a ponto de ficar... Investigando.

Pesquisadora - Não. Mas o que eu estou te falando é que você poderia me dizer: "Gabriela, pode mostrar o áudio". Eu te diria: "P2, eu não vou mostrar". Você sabe disso.

P2 - Tá. Não, tudo bem. Pula isso aí. Pra mim isso aí não importa também, que eu já passei tanta coisa. Obrigado. Pra mim isso aí também não importa, não. Pode sim importar pra você, eu tenho certeza que tem uma importância tão grande para você. Imagino a importância que você tá. Só que a minha vida tá tão num lugar que não tá totalmente perdida, mas... Eu não tô ligando tanto pras coisas assim...

Pesquisadora - Para a sua vida?

P2 - Não! Eu tô ligando. Mas assim, pra isso aí, entendeu? Eu não sei que você tá focadona e tal. Você faz sempre me tranquilizar, pra você chegar no resultado que você quer e tal... Eu tô te entendendo. Eu tô aqui, mas tô prestando atenção assim...

Pesquisadora - Entendi. Você já me captou inteira.

P2 - Nem tudo. Entendeu? Nem tudo. Mas... É.

Pesquisadora - Mas você acha que eu sou só legal porque eu quero que você converse comigo? 
P2 - Não. Pelo menos até onde... Eu te considero. Até você me provar o contrário...

Pesquisadora - Obrigada.

P2 - Entendeu? Teatro não é.

Pesquisadora - Não, mas eu...

P2 - Mas assim... Entendeu? É isso aí, entendeu? Por mim não tenho nada contra você. Não tenho nada que fale de você. Você não tem nada pra mim. Se você tivesse alguma coisa assim que eu não gostasse, eu chegava a falar com você, conversasse com você, entendeu? Que eu visse que era um negócio de conversar mesmo..., se eu visse coisa que não..., acho que nem queria participar. Nem olhar pra você eu olhava. Se fosse um negócio que... Eu falava: “mano, o negócio é assim, assim e assim”. De valer a pena também, às vezes, entendeu?

Pesquisadora - Não, mas a conversa foi legal.

P2 - De vale a pena. (risos)r

Senhora - Você estava me falando que você ficou entalado na janela! (risos)

P2 - Ham, ham!

Pesquisadora - Gente, e tua mãe? Você devia dar um trabalho!

P2 - Eu dava muito. Eu parei de sair pela janela o dia que a cabeça não passava mais. Aí tive que esperar a minha mãe e ou meu pai pra ver se vinha me tirar. (risos).

Pesquisadora - Eles demoraram?

$\mathbf{P 2}$ - (risos).

Pesquisadora - Tu apanhou?

P2 - Oxe! (risos). Preso na janela ainda. (risos) Ainda primeiro apanhei preso pra depois sair. (risos)

Pesquisadora - Eles demoraram?

P2 - Não lembro. Não lembro muito.

Pesquisadora - Gente! Imagina você lá preso na janela!

P2 - E doido pra sair antes do meu pai e da mãe chegar (risos). Nem tanto a minha mãe, mas meu pai. Nossa!

Pesquisadora - Eu acho que nunca conheci ninguém que tivesse apanhado preso na janela antes.

P2 - Não tinha o quê?

Pesquisadora - Conhecido ninguém que apanhou preso na janela.

P2 - Não foi apanhar muito assim não, umas palmadinhas eu levei ali antes de sair. 
Pesquisadora - O seu pai não batia em você? Só na sua mãe?

P2 - Meu pai? Me quebrava todinho! (risos)

Pesquisadora - Mas não te bateu muito no dia da janela?

P2 - Acho que não. Não lembro muito, sinceramente. Brigar, brigou, com certeza, mas não lembro muito disso não. Meu pai era uma pessoa que acreditava em todo mundo.

Pesquisadora - Mas ele te batia por quê? Quando te batia.

P2 - Ah, me batia com razão, sim. Não lembro muito. Com razão. Muitas vezes batia sem nada. Ele batia na minha mãe, porque a minha mãe falava que... Minha mãe chegava do serviço, à noite em casa, e ele lá em casa - ele já era aposentado, desde quando eu me lembro, ele sempre foi aposentado e novo. Porque a gente, quando eu me lembro, com sete anos de idade, ele já era aposentado e ele pegava várias latas; o pessoal gostava de pegar ele pra trabalhar no serviço de pedreiro. Ele pegava concreto e tal. Um cara bem forte, disposição, assim. Mas até onde eu me lembro, era aposentado e era um cara forte. Aí a minha mãe chegava em casa... Eu lembro, foi uma vez só, sabe? Duas. Vamos falar duas. Uma que a minha mãe chegava em casa, e ele começava a brigar com ela. Sempre caçava assunto com ela ou alguma coisa assim. E ela pegava e falava: "Filho, ele está assim por causa de café. Está sem café e sem cigarro. Vai lá, compra cigarro pra ele, um maço de cigarros para ele”. Aí eu acho que ela começou a falar isso aí duas vezes já antes. Aí teve um dia que eu me invoquei, eu tinha uns sete anos mais ou menos, sete para oito anos, aí ela chegou em casa para descansar e tal, cansadona porque ela saía de manhã, trabalhava de faxineira, diarista, saía de manhã e voltava à noite - sei lá. Ele começava a brigar por nada. Começava a caçar assunto. Começava a brigar mesmo. Começavam a falar merda e caçar assunto. E eu já ficava experto na porta, para correr, "qualquer coisa ela corre". Qualquer coisa ela corria, na porta, saíacorrendo. Ela já sabia que ele batia. Aí beleza, aí sumia e não falava pra ele. Às vezes dormia na casa do vizinho. Raramente na casa do vizinho. Às vezes esperava ele se acalmar. Ficava ela lá na rua, sentada na guia, até ele se acalmar, pra ela dormir, entrar, deitar, fazer comida, dormir, pra chegar no outro dia e ir trabalhar cedo. Levantar cedo pra ir trabalhar. E aí ela pegava e falava: "Vai filho, tá com certeza sem cigarro e sem café. Compra lá para ele, compra lá para ele", quando ela tinha o dinheiro. "Compra pra ele" e tal. Eu falei: "Não, mãe, o quê? Faz isso não. Não faz o gosto dele não", falava para ela. "Faz o gosto dele não". Não queria fazer o gosto dele. "Não faz o gosto dele não". Mas ela: "Mas filho, ele vai se acalmar”. "Não, não faz não”. Aí eu não lembro. Acho que eu comprava lá pra ele.

Pesquisadora - Você era muito novinho, não é? 
P2 - Hum?

Pesquisadora - Você era muito pequenininho.

P2 - É. Às vezes ele chegava em casa... Teve uma vez que ele chegou lá, ela desceu..., ela desceu o bairro correndo, ele jogou um bloco bem na cabeça dela, nas costas dela. Jogou assim: vupt. Por nada. De graça! Tudo! A maioria das coisas! Tudo de graça! Minha mãe não dava motivo pra ele. Tudo de graça! Todo mundo gostava dela, não conversava com ele. Não conversavam muito com ele não. Até que um dia, eu tinha uns doze anos, eu falava merda pra minha mãe pra não... Eu com doze anos.

Pesquisadora - Mas você defendia ela.

P2 - Muito. De vez em quando sim... Comecei a fumar maconha com onze anos, doze anos... E comecei a pensar mais. Eu andava no meio dos caras meio doidos, e aí começava a pensar mais, assim... Começava a colocar mais raciocínio. Eu pensava: “poxa, se eu vacilar aqui vou morrer. Se eu vacilar aqui eu vou morrer”. Aí eu ficava..., colocava a mente para funcionar. A mente já era mais evoluída. Pouca idade, mas bem evoluída já. Aí não falava muito com ele assim não.

Pesquisadora - Mas hoje em dia você sente saudade de casa?

P2 - Ah, isso aí sempre senti. Já superei um pouco assim... Sei lá, sempre fui louco. Mas já chorei muito já. Muito assim, já chorei duas vezes, quando eu saí da minha casa duas vezes. Chorei mesmo. Chorei não, quase que eu morri com a decisão, quase morri de chorar. Quando eu chorava, tava em casa, quando acordava e tava na rua. Ah, Nossa! Eu chorava. A lágrima descia na hora. Dava uma raiva. Aí, depois eu... Já fui lá dentro de casa já, escondido, fiquei parado lá dentro de casa, achei que ia ser aquela emoção, nem foi, de tão frio que eu já tava. Foi no ano passado. Fui lá. E tava num tempo assim, mesmo tempo, por isso que eu fui. Eu só ia até o terminal do Jardim Ângela. Depois eu peguei e dormir. Não, eu dormir, fui dormir (risos). Eu só ia até o Terminal do Jardim Ângela, aí: “Ah, vou ver como tá pra aqueles lado, nunca mais vi. Vou lá ver, dar uma olhada”. Eu não andava, eu chegava, tava chovendo. Eu tava no Centro. Tava lá. Fui procurar almoço pra comer, que acho que era um domingo. Foi num domingo. Fui procurar uma coisa pra comer, aí ficava: “Ah, vou ver se passa alguma coisa pra comer”. Mas sempre passa, uns pão, marmita unsvoluntários e tal. Fui lá, de lá eu peguei o ônibus, tem o ônibus do Jardim Ângela lá, fui, peguei o ônibus do Jardim, fui até o Terminal do Jardim Ângela e... Chegou no terminal do Ângela, desci no terminal do Ângela e não pensei duas vezes, falei: "Mano, quer saber? Eu vou lá em casa.” (risos). Fui sem medo de morrer. Sabe? Nossa! no começo ia saía, fiquei 
em choque. Fu falei: "O quê? Vixe, eu vou morrer, vou morrer. Se eu ficar em São Paulo eu vou morrer". Depois fui parar lá dentro de casa. À noite. Chovendo assim, garoando. Cheguei lá acho que umas 9h da noite, oito e pouco. Era umas 9h, eu acho. Chovendo e eu coloquei o capuz. Daqui pra a minha casa... Do ponto do ônibus até minha casa fui de ônibus, do ponto de ônibus até a minha casa, dava daqui nessa esquina. Daqui no farol. E eu coloquei o capuz, o capuz da blusa. Falei: tanto tempo que eu não vou lá, que muda tanta coisa, tantas pessoas mudou lá e tal. Tem um monte de gente me ligando lá e tal. Conhece, me consideram. Aí eu peguei e fui lá sem medo nenhum. Cheguei lá, bati palma, meu irmão abriu a janela e olhou assim: "Você é doido?”. Falei: “doido?” (risos).

Pesquisadora - Só um pouquinho. Um bucadinho.

P2 - É.Só um pouquinho. Um bucadinho. (risos). Você acredita? Você é filha da puta também, né? (risos).

Pesquisadora - Por quê?

P2 - Ai, caramba!

Pesquisadora - Fazendo piada.

P2 - Eu sei. (risos). Aí eu fui, assim... Não é que eu era doido. Eu acho que o sofrimento alimentou muito a minha coragem, sabe? Acho que alimentou mais a minha coragem; falei: "O quê? Não tô nem á́".

Pesquisadora - Você acha que você sofreu muito na vida?

P2 - Em vista de muitos? Não.

Pesquisadora - Tem gente que sofre mais?

P2 - É. No meu ponto de vista, tem gente que está... Antes eu tava com uma palavra da hora agora na mente assim, mas... Tipo de pessoas deficientes, assim, entendeu? O que tem de pessoas deficientes e tá sorrindo. Entendeu? Às vezes eu penso que ela pode tá sofrendo mais assim, mas ela... Pode até tá, assim, por nada, mas ela tá ali sorrindo até umas hora e eu que... Né? Não tô, assim...Não tenho deficiência e tô reclamando. Às vezes eu reclamo demais, barriga cheia. Tá certo que eu tenho uns motivo também, que é um negócio que vem de criança mesmo. Têm umas coisa assim, pra mim, assim... Não físicamente comigo, mas... Ah, perdi muito tempo da minha vida, assim. Fui acordar já era tarde. Porque não é tarde pra mim assim..., por esse lado, mas pelo lance lá, pelo fato da minha mãe, pela minha mãe... Minha mãe era de dar aula, minha mãe dá aula, trocava mó (sic) ideia, extrovertida, trabalhava... Não é porque ela é a minha mãe, mas ela era guerreira, mesmo. Guerreira! Nossa! Perdi tudo, o papo com a minha mão e tal. É isso mesmo. Não tinha tempo ruim com 
ela. E aí eu fui acordar a vida já tava na rua quando fui acordar pra a realidade, um pouco, já acordei já. Mas já não volta mais, né? A mente dela. Uma coisa que eu queira. Eu penso assim: se eu tivesse a mente de hoje, se eu tivesse a mente de hoje... Se antes eu tivesse a mente de hoje, daria conta de trocar a maior ideia com a minha mãe. Agora, hoje que tenho uma mente mais madura, e eu queria trocar ideia, conversar com a minha mãe, assim, legal... Pelo que eu me lembro dela, nossa! a gente se dava bem conversando, só que eu não dava muita atenção, assim. Eu gostava dela, amava ela, eu dava com ela, conversava com ela, mas não era muito... Eu dava mais atenção pros outros de fora, da rua, o pessoal da rua. Só ia em casa mais pra dormir, muitas das vezes. Você teve mãe, você também é mãe, né? Tudo de bom, nossa! Mas, tal. Perdi muito tempo, assim, mais lá fora do que dentro de casa, família. Tipo foi cada um pro lado, assim, sabe? Minha mãe sempre era do lado de todo mundo, assim, pegava todo o mundo, mas eu lembro... Eu e meu pai não se batia, muito, por causa desse negócio, assim. Às vezes eu conversava. Eu lembro assim... Eu tenho, eu tive momentos bons com ele, assim, tive momentos. Tive. Mas muitos momentos ruins também que foi o que eu mais guardei assim. Tinha momentos que ele zuava, implica com a minha mãe, briga com a minha mãe de graça, por nada.

Pesquisadora - Vamos lá? Vamos acabar?

P2 - Vamos.

Pesquisadora - Então, muito obrigada.

P2 - De nada. 


\section{ENTREVISTADO: P3}

Arquivo de Áudio: 130715-001

Tempo: 00:36:42

Pesquisadora - Me fala seu nome completo.

P3 - É (...)

Pesquisadora - Sua idade?

P3 - 36.

Pesquisadora - Escolaridade?

P3 - Superior completo e fiz um ano de mestrado, mas só os créditos.

Pesquisadora - Você se formou em quê?

P3 - Em Engenharia Eletrônica.

Pesquisadora - Ah, é, você se formou lá fora, não é?

P3 - É.

Pesquisadora - Onde e com quem você mora?

P3 - Eu moro sozinho atualmente, mas é perto da casa da minha mãe.

Pesquisadora - E por que você escolheu morar sozinho?

P3 - Porque depois que eu voltei da Inglaterra, eu acho que não me adaptei mais morar com a minha mãe, essas coisas assim; e no caso eu tinha já um apartamento que eu alugava, aí eu decidi morar lá.

Pesquisadora - Como é que começou o seu uso de drogas e como ele evoluiu? Quais as suas drogas preferidas?

P3 - Eu comecei a usar droga tardiamente, não é? Geralmente na adolescência eu só bebia. Nunca fiz uso de drogas. Eu comecei a usar droga... Experimentei uma vez só, cocaína, quando eu tinha uns 20 anos, que eu trabalhava no Aeroporto, que é um ambiente que não é muito...

Pesquisadora - Mas começou com cocaína, não teve maconha antes?

P3 - Não. Mas eu usei duas vezes só. Depois eu fiquei uns quatro anos sem usar droga. Pesquisadora - Usou duas vezes a cocaína?

P3 - É. Aí depois fiquei quatro anos. Aí eu com 22, assim, eu comecei a fumar maconha. Aí maconha eu fumei muito. Fumei assim... Até hoje fumo um pouco, não é? Mas eu tive uma 
fase que eu fumava pesadamente, né? Porque eu tinha uns colegas, que fumavam, tudo. Aí eu tinha um colega meu na Varig, ele morava pelo lado da Vila Alpina, morava lá na fronteira com São Caetano, não é? E aí tem muito bandido, não é? E aí um dos colegas dele de infância era bandido, era... ele tinha desmanche de carro e essas coisas, e ele... Você sabe que esse pessoal da bandidagem todo conhece traficantes, conhecem..., eles são todos interligados através desses... E ele comprava para ele quilos de maconha muito boa. Entendeu? Não é essas de favela, não é? E aí, como eles eram colegas, ele pegava para mim e eu peguei, durante vários anos, eu usei essa maconha muito forte. E bebia. Mas comia pouco porque era mais maconha, mas isso não me atrapalhou na Faculdade não, consegui me formar e tudo. Sempre trabalhei. Só que o problema, que daí quando eu comecei a frequentar lá, que a gente saía junto, a gente também tinha acesso a cocaínas muito boas, entendeu? E aí foi que eu voltei a usar cocaína.

Pesquisadora - Entendi. E hoje em dia você usa o quê?

P3 - Então... Aí depois... Aí eu comecei a usar assim, bastante e aí chegou uma hora que... De você vai um domingo, eu fumava; era assim: sempre fumava um cigarro, aí eu bebia, aí me dava aquela fissura para usar. Então às vezes eu usava durante a semana, eu ia trabalhar podre, essas coisas. Eu não chegava a perder dia de serviço não, mas... Aí depois que eu fui para a Inglaterra e tudo, aí eu parei de usar cocaína. Lá eu fumava também maconha muito forte - skank; às vezes eu tomava, não direto, mas ecstasy. Muita química, não? E ketamina, que é o Dopalen, que é um anestésico de cavalo que você pode comprar em qualquer casa agrícola, aí cozinhar ele para secar. Depois eu voltei, e quando eu voltei... Não. Aí, quando eu estava na Inglaterra, entrou inverno, de cara bateu uma depressão - eu tinha uma namorada lá e tudo, mas você sente uma falta... Eu não sei se tive oportunidade de falar, mas o inverno é muito ruim, é muito cinza, escurece cedo. E aí eu comecei a beber demais lá. Porque a bebida é barato lá e são boas as bebidas. Elas não são que nem as bebidas aqui, que vai ter ressaca, e tudo. A mais vagabunda você pode tomar que não vai... Com exceção de tomar cerveja lá que tinha, de alto teor que era ruim, dava um ressacão.

Pesquisadora - Whisky era bom?

P3 - Whisky era. Whisky era bom. E outra, eu não tinha compromisso com nada. Os empregos eram temporários. Então eu fazia a minha agenda, tudo. E só tem louco naquela terra. Se quiser trabalhar podia trabalhar e beber por que... Engraçado que o povo da Europa... Então tinha bastante polonês, essas coisas - a bebida para eles não é vista como um problema social, não é? Entendeu? Já faz parte da cultura deles, apesar deles terem um 
índice bem grande de alcoolismo, não é? Eles bebem, assim, de cair duro e quebrar o dente no chão; de cair assim: puf! E não é só pessoa pobre, adolescentes, você vê executivos assim. Eu via em trem, metrô, assim que..., de no metrô, ele está na porta, o metrô frear, e ele pum! Cair. O ônibus fazer a curva e o cara caía. E pessoas normais. Mas não é vergonhoso para eles. Aí eu bebia e voltei bem magro de lá porque eu não comia direito e bebia bastante. $\mathrm{O}$ alcoolismo ele deixa...

Aí eu voltei. Comecei a trabalhar logo de cara em uma empresa que vendia componentes eletrônicos; eu fazia, era supervisor técnico, eu mais fiscalizava os vendedores, por que... Mas o vendedor, ele pede para você fazer uma importação e você tem um número X para você importar. Vai, "Você precisar importar 1000 peças”, o cara vende só peças, 100 peças, e 900 ficam paradas em estoque. Porque às vezes é uma peça muito específica, não é um commodity que pode ter... Quer dizer, você tem commodities em termos de componentes eletrônicos que sempre têm grande saída, que são básicos. Mas têm componentes específicos. Então eu fazia essa parte de fiscalização deles. Eu ia em cliente eu ia assim e passava para o dono da empresa, para o gerente. Quando tinha gerente, né? Porque ninguém era mandado embora, porque o gerente lá ele focava direto.

Aí o que aconteceu? Eu voltei meio politicamente correto de lá, nessa época que eu estava trabalhando eu não usava coca, nada, mas eu bebia. Então eu trabalhava, saía, fazia academia e de noite tomava um quinto de Vodca, mais umas duas, três latas de cerveja. E aí eu, como se diz, eu ia dormir. E aí quando a empresa faliu, eu saí, fiquei desempregado e aí voltei a usar um pouco de coca, mas não muito. E aí, quando antes de sair culminou quando descobri que estava fora da empresa, e aí que veio o problema da bebida mesmo. A bebida forte. De beber pesado, entendeu? E até agora não voltei a trabalhar, porque aí, mesmo quando eu já estava trabalhando eu já estava tendo problema de pânico. Porque eu acho que o meu uso abusivo de maconha que usei por muito tempo, com coca, essas coisas, deu algum desequilíbrio na cabeça, aqui.

Pesquisadora - Entendi.

P3 - Eles falam que maconha não faz mal e essas coisas, mas tudo em excesso faz mal, né?

Pesquisadora-É.

P3 - Então essa coisa de maconha não fazer mal, eu acho que para adolescente é extremamente ruim. Se a pessoa tem uma predisposição já com algum tipo de doença, ela acelera, e se você fizer um uso abusivo muito intenso e parar, você vai ter problemas. Eu sempre fui ansioso... 
Agora, com relação ao crack, eu uso recreativamente. Eu gosto de cocaína mesmo. Eu uso assim, eu pego um Faustão, que dizem que é cinco gramas, o maior, de R \$ 50,00 e pego duas pedrinhas pra brincar, entendeu? Mas eu não gosto, não tenho aquilo porque é uma coisa que consome muito dinheiro. Não é uma coisa que você pode usar em qualquer lugar que nem cocaína que você entra, não tem o cheiro, e é uma coisa que tem um efeito muito rápido, entendeu? Passa rápido. Não é uma coisa mais intensa.

Pesquisadora - Não vale a pena?

P3 - É. Você gasta muito dinheiro. Não é interessante. Prefiro cocaína mesmo.

Pesquisadora - Entendi.

P3 - E doce, bala, sei lá, o que aparecer assim e estiver a fim. Bala nem tanto, porque, como eu tomo antidepressivo por causa do pânico e da ansiedade, eu tenho algumas restrições, comumente.

Pesquisadora - E o que te levou a buscar o tratamento? Essa é a primeira vez que você buscou o tratamento?

P3 - Não, não. Eu já me trato há uns quatro anos. No CRT, no Centro de Referência e Treinamento de Aids e Doenças - DST, né? aqui na Santa Cruz. E lá, logo que eu fiz o acolhimento e eles perguntam se usa droga, tudo, eu já fui encaminhado para o psicólogo e psiquiatra porque é importante, apesar de eu não fazer uso de antirretroviral, se você precisar, você precisa estar com o organismo bom. Entendeu? Então eles têm um trabalho. $\mathrm{Na}$ verdade, cocaína e Aids andam lado a lado, entendeu?

Pesquisadora - Por que você acha isso?

P3 - Porque a cocaína, primeiramente, ela te dá uma excitação sexual muito grande. Então... Você tá maluco, e a maioria das prostitutas, tudo, esse pessoal aí da noite usa muita droga e aí você tem uma droga, aí a pessoa já faz um programa pela metade, aí você já se entrega em dois dias. E acaba às vezes transando sem preservativo. Você está muito louco.

Pesquisadora - Você fica mais vulnerável.

P3 - Mais vulnerável. Tem esse lado. E tem o lado também de você tá em uma roda... Hoje não se usa mais droga injetável. Que nem esse colega meu que eu tinha na Vila Alpina, o primo dele também era soropositivo, mas eu nem sabia que era. Eu, não é? Ele sabia. E ele pegou de drogas injetáveis e hoje... Hoje em dia, ele falava que a droga injetável tinha decaído muito, tanto em presídio como nas ruas em gerais, porque a cocaína é muito misturada, não é? E com a chegada do crack, dá um efeito até mais intenso.

Pesquisadora - Do que injetável? 
P3 - Do que injetável.

Pesquisadora - Intenso?

P3 - Mas qual é o perigo da cocaína? É que quando você cheira a cocaína, se ela não tiver boa, se ela tiver muito ácida ou muito alcalina, que não foi bem preparada, dependendo da porcaria que eles colocarem lá dentro, aí os caras colocam às vezes cal, que queima, e você sangra o nariz. E ás vezes você tá em uma onda assim, no carro, não sei o quê e você compartilha canudo. Então é...

Pesquisadora - Também tem risco grande de transmissão.

P3 - De transmissão. Muito alto. Muita gente pega por...

Pesquisadora - Por causa do canudo.

P3 - Por causa do canudo.

Pesquisadora - Entendi.

P3 - E também por uso de notas. Você pode pegar outras doenças por usar notas de dinheiro. E eu quando uso, hoje em dia, geralmente eu... Primeiro que eu não compartilho. Nem canudo, baseado também eu fumo o meu, difícil entrar em uma roda... E se eu usar o canudo, geralmente eu uso o papel de banco, ou uma folha de sulfite ou uma coisa assim, mas nunca teve contato. A coisa mais suja que existe é o dinheiro.

Pesquisadora - Dinheiro. É verdade.Então você buscou o tratamento, na verdade, por causa do HIV, não foi por causa da droga? A decisão...

P3 - Não, eu já tava em tratamento por causa do pânico, né? Que eu já tinha.

Pesquisadora - Mas alguma vez você pensou em buscar tratamento por causa da droga? "Olha, eu acho que a droga está me atrapalhando."

P3 - Não. Porque antes de eu descobrir que estava com HIV, eu levava uma vida... Me formei, estudei, trabalhava, então não me atrapalhava, entendeu? Aí a partir do momento que o alcoolismo, mais o alcoolismo, e a droga a começou a me atrapalhar, e tive o problema do HIV também, né? Que você tem que tá com o organismo bom, aí sim eu procurei tratamento.

Pesquisadora - Entendi. Mas eu posso entender que o gatilho que te motivou mesmo foi o HIV?

P3 - É.

Pesquisadora - Aí você pensou em tratamento. Alguma vez você já desistiu?

P3 - Do tratamento? Ah, sim. Às vezes você tem recaída e você fica um tempo meio afastado, né? 
Pesquisadora - E o que te faz voltar?

P3 - A ter recaída?

Pesquisadora - Não, que te faz voltar a se tratar.

P3 - Ah, porque eu necessito.

Pesquisadora - Por que você necessita?

P3 - Por exemplo, eu fiz exame no começo do ano. Eu tô com 700 de triglicerídeos. Isso para você desencalhar uma pancreatite ou uma... Porque quando passa da 500 você tem que entrar com medicação. Porque o normal é 160. Então eu com 700, isso aí pode dar uma pancreatite, como posso vir a ficar diabético, que nem meu pai ficou, que foi alcoólatra. Tenho outro conhecido também que foi alcoólatra. Meu pai foi porque morreu, morreu bebendo. Esse conhecido ele parou, mas ficou diabético, então... E fora o fígado, porque se você danificar muito ele e tiver que tomar a medicação... Olha, um exemplo muito clássico, quando eu tive essa infecção intestinal, que eu perdi 15 quilos, que eu fiquei doente, eu tive que fazer um exame de pâncreas, amilase e lipase, e os parâmetros de fígado, fora os hemogramas para ver a infecção, que eram TGP, TGO e Gama GT. O que acontece? Para ver se eu tinha condições de suportar o antibiótico que eu ia tomar; porque eu tomei um antibiótico muito forte, o Ciclofloxacina. Então se o meu fígado não estivesse em condição, então é por isso que eu preciso, tenho que estar atrás, né? De reduzir....

Pesquisadora - Entendi.

P3 - Lá eles trabalham não com abstinência total, mas mais com redução de danos, né? Tipo no caso do uso de cocaína, você usar seu próprio nariz, acabou de usar, fazer aquela lavagem, com soro e tudo, entendeu? Isso aí evita que você fique com uma sinusite crônica, com uma infecção crônica no nariz, essas coisas.

Pesquisadora - Entendi. E você já se sentiu - agora é um pouco mais de sentimentos - você já se sentiu diferente das outras pessoas por ser usuário de drogas?

P3 - Ah, já! Você fica estigmatizado, né?

Pesquisadora - Por quê?

P3 - A sociedade te... Ah, primeiro é um problema: Olha, eu tive problema de drogas, essas coisas, bebida, eu tenho pânico que foi desencadeado, não estou trabalhando, as pessoas na sociedade não aceitam, apesar de eu ter dinheiro para me sustentar, essas coisas, elas pegam e acham que você é vagabundo, que não sei o quê. Quando você bebe, “ah, tá vendo? É porque ele bebe, que aconteceu isso". Uma vez eu levei um tombo na rua, e não estava bêbado. Vieram falar que era porque eu estava bêbado. Então isso magoa muito. 
Pesquisadora - Você acha que prejudica até o tratamento, esse estigma?

P3 - Ah, sim. Está vendo? "O cara pegou HIV, porque ele é um merda, usou droga pra caralho e se fudeu", entendeu? Então é mais ou menos. Minha família sabe que eu tenho. Então... Você fica meio que marginalizado. A sociedade te marginaliza. Ela não entende que é uma doença. Hoje, por exemplo, a minha irmã, minha mãe, já têm outros olhos comigo, já me trata melhor, porque ela está vindo no grupo familiar aqui. Aliás, ela é mais assídua do que eu. Então ela parou de ser muito crítica, muito assim, de pegar no pé, essas coisas. Entendeu? Porque até antes delas não saber que eu tinha HIV, nossa! Era um inferno! "Você é um vagabundo, você não sei o quê". Então, quando ela descobriu tudo, aí ela...

Pesquisadora - Ficou mais tranquila.

P3 - Ela passou a entender, né? E ela vindo aqui... O que a sociedade não entende é que a pessoa que é usuária de drogas e, essas coisas, é uma doença. É uma doença física, psíquica. Física eu digo no caso do álcool ou heroína, essas coisas. Então física, psíquica, todas. E é uma doença social também, porque fica com problema social também.

Pesquisadora - Você já teve algum problema com a polícia?

P3 - Não.

Pesquisadora - Nenhum? Nenhum contato, nunca te abordaram...

P3 - Ah, já. Já me abordaram várias vezes já. Mas é...

Pesquisadora - Então, eu digo isso, alguma experiência. Já teve.

P3 - Assim, com a polícia? Já, já, já tive assim de ser abordado na favela.

Pesquisadora - E relacionado com droga?

P3 - Com droga, com droga.

Pesquisadora - E como foi?

P3 - Uma vez eu tava indo... Qual que era a favela? Era a Mauro, aqui embaixo.

Pesquisadora - Foi essa ou depois de buscar o tratamento?

P3 - Antes. Quando era moleque. Na Mauro a gente se virou, que era um Drive thru, e eu tava com o dinheiro já para fora, aí quando eu vi eu tava uma... Na verdade era uma barca, vai, da Polícia Civil. Aí como o meu colega..., eu tinha os documentos, o cara viu que eu morava no bairro, que a gente frequentava, eu tava com as carteiras da universidade e tudo. Eles só acharam um baseado no carro, aí não teve problema. A Polícia Civil é mais tranquila, ela não enche muito o saco do usuário.

Pesquisadora - A militar enche? 
P3 - Ah, a militar é. Porque a Polícia Militar se você for analisar, primeiro... Eu até estudei para concurso público para a Polícia Civil, que ia ter um concurso, e você precisa ter certo um conhecimento e estudar bastante pra passar, não é fácil não. Já a Militar, a pessoa, já é baixo nível de instrução que eles têm.

Pesquisadora - E por isso você acha que eles pegam muito no pé do usuário?

P3 - Ah, eles têm, porque quando eu fazia faculdade, uma vez eu tava saindo de lá, eu vi uma PM falando para o outro que eles tinham que fazer a segurança, montar barreira: "Ah, é uma merda aqui, a gente ter que vir cuidar esses playboys folgados, tudo maconheiro, essas praga, tudo filho da puta, a gente tinha que meter tudo na cadeia”. Papo idiota. A Polícia Civil não é que ela não pegue no pé. A Polícia Civil o que acontece? O negócio dela é dinheiro alto. Então eles trabalham mais com o tráfico mesmo. Então eles têm um arrego, né? Eu já vi diversas vezes, você tá na fila para pegar, aí você tem que esperar o cara da Civil descer. Geralmente é sexta-feira que eles têm o "arrego". Era, né? Hoje eu não sei como é. Mas descia e saía com o pacote de dinheiro. Só que à paisana, né? Depois os caras da boca comentavam que: "a Polícia veio pegar aí" e não sei o quê.

Pesquisadora - Era um pagamento periódico.

P3 - Periódico. Eles têm.

Pesquisadora - Para eles poderem continuar.

P3 - Para eles não encherem o saco, né? A PM...

Pesquisadora - Como chama isso?

P3 - Arrego. É arrego, vamos dizer, é o dinheiro da semana para eles poderem trabalhar.

Pesquisadora - Então eles contam para quem está lá...

P3 - Ah, é porque não é o traficante, é molecada, né? Porque quem tá na boca, não mora na boca, entendeu? Eles vêm pra favela, trabalham, trocam de turno e nem "paiol" de droga fica na favela. Eles ficam num lugar completamente diferente, você nunca vai imaginar onde fica. Então periodicamente vem o "vapor" - que é o que traz a droga e ele recolhe o dinheiro e aí leva para onde tem o "paiol” que está lá, e geralmente quem está vendendo é menor, é molecada. Tanto é que você vai numa semana, na outra semana já não é a mesma pessoa. Porque vem a Polícia Militar e leva. Geralmente, se não pagou, aí fecha. Aí não funciona. Então o que acontece? É que nem na Espraiada aqui, eles... Tinha uma favela que vendia muito, eles botaram uma base da Polícia Militar na frente da favela, na Emboabas ali que é sem saída. Aí os caras mudaram para a esquina do lado, entendeu? Então não tem... Que nem diz o cara do DENARC, que ele fala que é enxugar gelo isso daí. Porque eles colocam 
menor. E há quantos anos isso?! Uma boca, eu calculo, por baixo, que gere um..., que tenha um faturamento líquido, um faturamento de R 100 mil por dia. É muito dinheiro envolvido. Pesquisadora - E você acha de algum jeito que essa abordagem da Polícia te fez pensar...? P3 - A PM não. Já aconteceu de eu ser abordado pela PM e eles serem bem truculentos e mal educados.

Pesquisadora - É? Como foi? Me conta.

P3 - Ah, tava eu e acho que um morador de rua. A gente estava esperando abrir a boca, porque o que acontece? Quando chega o vapor eles têm que fechar a contabilidade e contar das drogas que vieram para eles poder... Porque se ficar faltando o cara se ferra, então é como fechar o caixa, né? Então você fica aguardando eles abrirem, né? Geralmente é em torno das $8 \mathrm{~h}$ da noite que geralmente tem, e daí vai até... Bem, de madrugada não sei se acontece, mas geralmente eles pegam às $8 \mathrm{~h}, 9 \mathrm{~h}, 10 \mathrm{~h}$ e aí vai até acabar. Enquanto tiver vai até 4 h da manhã, 3h30. Às 3h já acabou, né? Está fechada. Algumas. Têm outras 24h. As que eu frequento geralmente são...

Pesquisadora - 24h?

P3 - Não, não. Elas abrem às 11h, meio-dia e vai até... Então é assim. Agora, a Polícia Militar ela já aconteceu assim: "cadê o bagulho? Cadê o bagulho?" "Eu não tenho, não sei o quê"... Já aconteceu com um amigo meu, ele desceu na favela e a Militar estava de olho. E eu estava no carro. Aí eu vi, peguei e saí fora. E ele já tinha descido e não tinha visto que a Militar estava do lado, assim, escondida, olhando. Aí o que aconteceu? Quando ele viU eu saindo, eles recolheram as drogas dele, pegaram o carro dele: “Ah, sua placa não tá dando para ler", porque tava riscadinha, "ah, não sei o quê"... Eu sei que ele tomou umas cinco multas depois que ele passou pela Polícia Militar. Só de sacanagem. Eu já tive colegas...

Pesquisadora - Eles não levaram para a delegacia?

P3 - Não. Não. Não. Se você tiver dinheiro no bolso eles tomam.

Pesquisadora - Aí eles não te levam?

P3 - Não. Então quando eu vou na boca, geralmente eu vou com R\$100, R\$ 150 a mais. Geralmente eu gasto R\$100,00 quando eu vou. Porque eu não uso direto, todo dia, não é? Então eu uso recreativo. Então eu me programo. A cada 15 dias eu vou pegar e aí eu pego uma quantidade legal. Mas sempre levo um dinheiro a mais, caso eu seja abordado, porque se tiver dinheiro no bolso eles levam. Mas já aconteceu de um colega meu, o cara pegar, virar o pacote de cocaína, jogar no chão e mandar o cara cheirar, da Polícia Militar.

Pesquisadora - Entendi. 
P3 - Entendeu?

Pesquisadora - Então você acha que algum jeito, alguma dessas abordagens da Polícia ou da Civil ou da Militar, fez você pensar em procurar se tratar?

P3 - Não. Nada. Nada a ver.

Pesquisadora - Nunca te ajudou a pensar: "poxa, é crime e tal...".

P3 - Não. Não, não. O que eu fiquei um tempo sem usar foi porque se a gente for parar pra olhar, indiretamente a gente financia esses assaltos, esses sequestros, esse pessoal ai, né?

Pesquisadora - Mas mais por um sentimento de solidariedade ou talvez vítima do que pensar "poxa...".

P3 - Não. Não porque a Polícia é corrupta. Não tem... É que nem diz, quem vai preso nesse país é pobre. Se você tiver uma boa quantidade no bolso, eles não te levam não.

Pesquisadora - Entendi.

P3 - E outra, se eles te levarem também o cara vai ter que caracterizar tráfico, né? Mas, por exemplo, já sei... Que nem uma vez esse meu colega aconteceu...

Pesquisadora - Mas por que vai ter que caracterizar o tráfico?

P3 - Porque, por exemplo, se o cara te pegar com 10 pininhos de cocaína, ele pode dizer que você tava vendendo.

Pesquisadora - Mesmo você estando...

P3 - Dinheiro miúdo no bolso também caracteriza. Agora, se ele te pegar com uma ampola de $\mathrm{R} \$ 100,00$, ele sabe que não é tráfico.

Pesquisadora - Mas aí portar para uso, também é crime.

P3 - Sim. É um crime, mas que você faz um termo circunstancial. Não é mais um 16 que você assinava e ficava com o nome lá não sei quanto tempo sujo. Essas coisas, mudou.

Pesquisadora - E aí é como venda por que...

P3 - Não. Não. Não. Uma, primeiro que tá pago. Vou te dar um exemplo. Outro dia eu estava na boca; o cara tava lá dentro e o cara já passou por lá: “Ó, a Polícia tá chegando”. Eles já correram, eu peguei, saí, fui andando duas quadras depois; ele já tava abordando, a Polícia. Então, eles têm um sistema de vigilância muito grande. Se tiver polícia na área, pegando, que eles não tenham pago... Eles sabem pela cara de quem vai abordar, quem não vai abordar eles; então eles passam via rádio e fecha a boca.

Pesquisadora - Eu sei. Mas em relação ao crime de uso. Ele não amedronta por amedronta porque é o termo circunstanciado?

P3 - Não. Não. 
Pesquisadora - Seus amigos também não se preocupam com isso? Não é uma preocupação dessa sociedade?

P3 - Não, porque se você for parar para ver a Cracolândia, que coisa pior? Passa a Polícia e os caras ali, mas...

Pesquisadora - Então não dá nada? Usar não dá nada?

P3 - Não. Usar não. Você traficar dá. Você roda. Se você quiser ter os olhos grandes, ser um vicioso, aí tem problema. Que nem aconteceu com um colega meu - vou te dar um outro exemplo - ele era playboy, de boa família, morava em Perdizes, pai advogado, só que ele era um sem noção, né? Porra louca. Ele começou em rave e conseguiu uns contatos e ele começou a vender e viu que dava dinheiro. Ele tirava uns $\mathrm{R} \$ 6.000,00, \mathrm{R} \$ 7.000,00$ numa rave. Ele começou a traficar, pesado. Ganhava dinheiro. Aí, a primeira vez que ele rodou na rave foi com a Civil. Aí que eu falo, quando envolve dinheiro alto, é Civil. Agora, quando é dinheiro pouco, que é pra zoar, é PM, entendeu? Então a Civil pegou ele uma vez, aí ele ganhou o mundo; uma vez, e aí ele continuou e não sei o quê. Aí os mesmos caras pegaram ele de novo. Olha, eles pegaram acho que uns $\mathrm{R} \$ 20.000,00$ dele, uns $\mathrm{R} \$ 30.000,00$. Aí eles ficaram monitorando ele. O dia que ele foi fazer uma compra grande no shopping - Civil que eu falo é o Denarc. Eles são infiltrados - que ele foi fazer a compra, a Civil prendeu ele. Aí ele tinha comprado acho que 700 balas, a Civil ficou com 400, o Denarc e mandou ele assinar que tivesse 300 e se ele falasse qualquer coisa que eles tinham pego as 400 balas, ele ia morrer. Entendeu? Tanto é que se hoje você ver o jornal, já teve uma ação muito grande em Campinas e São Paulo no DENARC para prender o pessoal aí corrupto e... Mas essa ação foi desencadeada por há dois meses atrás a Polícia Federal prendeu acho que cinco do Denarc que tava achacando o traficante. Eles iam, tomavam a droga do traficante e...

Pesquisadora - Faziam vista grossa.

P3 - Faziam vista grossa. Extorquia, sequestrava o cara. Vou te dar um exemplo. Tem um cara do DENARC que mora na Lapa, que inclusive é no prédio de um conhecido desse meu colega. Ele faz apreensão e passa para a molecada revender nas festas, nas raves. Entendeu? Pesquisadora - Entendi.

P3 - Então a Polícia toma, a Civil, quando ela pegam e passa para... Por exemplo, se você já está na mão deles, que ele já te prendeu uma vez, ele chegava "você não quer vender para mim isso daqui?". Ele vende e... Uma parte eles passam para frente, a droga. É bem assim que acontece.

Pesquisadora - Pelo fórum você nunca passou? 
P3 - Não. Nunca tive problema. Nem em delegacia. Só vou em delegacia para fazer B.O. quando eu brigava com a minha mulher.

Pesquisadora - Entendi.

P3 - Para fazer B.O. de roubo. Essas coisas assim, mas nunca por problema de ser acusado ou de ter feito uma...

Pesquisadora - Por droga dá apreensão, mas pelo menos por uso dá para resolver antes de ir para a delegacia?

P3 - Dá. Dá. O que não dá é quando... Ah, uma coisa também da PM que eu vou contar por isso que era bom ter muita droga em cima - lá na Faculdade a gente fumava na pracinha. Aí quando ele pegava...

Pesquisadora - Que Faculdade era?

P3 - Na São Judas. Tem uma praça ali. Lá tinha sábado, sexta-feira que ficava 20, 30 pessoas fumando maconha; era muita gente. Uma vez teve uma abordagem da Civil, de dois caras, mas foi uma abordagem que acho que não foi nem tanto, foi reclamação do pessoal dum conjunto que tinha, de prédios, que devia conhecer alguém de lá; eles fizeram a abordagem, checaram o RG de todo o mundo e falaram assim: "Você vai fumar? Vai fumar trepado na árvore, na água, aqui não é Jamaica, passa gente com crianças e essas coisas, então espero a colaboração de vocês, não queremos mais esse problema de muita gente aqui, porque isso acaba dando problema para nós”. Eles foram educados e tudo. Tranquilo. Agora, a PM quando pegava! A PM quando ela pegava, ela judiava. Fala assim: "Você vai ter que..., ou você come ou vou te levar para a delegacia”. Então eles são bem sádicos.

Pesquisadora - Mas se comer não vai pra delegacia.

P3 - Não. Então a sorte é que era pouquinho. Então... Eu nunca tinha. Eu sempre deixava no carro, tudo tranquilo. Mas já vi cara que estava com duas paranga e comer, depois aí pra vomitar depois, né? E outra, se você tá com uma grande quantidade de cocaína, você pode morrer. E eles fazem de propósito. Eles não estão nem aí. Eles têm raiva se você mora num bairro bom ou não sei o quê. Que nem o outro dia, eu tinha bebido, mas não tava assim perigoso; tinha um cara enchendo o saco dum flanelinha, enchendo o saco dos caras, e aí tem uma base lá na pracinha de Moema, e eu cheguei para o policial e falei: “Ó, tem um cara aí, achacando as pessoas aí"; "Ah, não tenho nada a ver com isso". Falei: “Tem sim. É obrigação sua. Isso aqui é a pessoa ficar extorquindo a outra"; "E quem é você?”, o cara já veio com... Só que o cara que fica na base ele sempre vê eu passando, porque eu moro em uma quadra de lá e eu passeava... Se não é o cara intervir, o cara ia querer me bater. 
Pesquisadora - Entendi.

P3 - Entendeu? Aí na hora que viu que deu confusão que daí eu voltei com mais umas três pessoas, eles tinham sumido de lá, não tinha mais ninguém. Tinha acho que uma ou duas policiais, femininas, que eu fui fazer..., porque eu fiz a reclamação para o Copom quando eu fui para casa, aí eles passam via rádio, aí os caras...

Pesquisadora - Se mandaram?

P3 - Se mandaram.

Pesquisadora - Tá. Eram essas as perguntas.

P3 - Então é assim. Todos são corruptos. A Civil é mais com valor alto e essas coisas, eles não são de zoar o usuário, essas coisas, eles não estão nem aí. Eles nem perdem tempo. Agora, a PM ela gosta de sacanear. Ela gosta. Tenho uma conhecida casada com um PM, o cara é um traste. Por quê? Primeiro que ganham mal, muito mal; eles têm que trabalhar dobrado, entendeu? E às vezes fazem até coisas ilícitas, que nem aconteceu aí, não sei se você sabe, na Rodovia, de um atirar no outro que estava recebendo dinheiro. E essa chacina que a PM fez, andou fazendo, que até saiu no Fantástico que eles, como se diz? O cara falou: "O ministro mete o capacete de noite e sai picando bala em todo o mundo". Então a PM... Então o que eu acho que deve acontecer é assim, exigir um grau melhor de instrução, e pagar melhor. É isso que eu acho. E a Civil, bem, aí... É outro problema. O que mais me afeta mesmo é a PM, a civil não.

Pesquisadora - Então tá. Obrigada. Eram essas as perguntas.

P3 - Tá $o k$. Isso aqui fica comigo? 


\section{ENTREVISTADO: P4}

Arquivo de Áudio:130717-001

Tempo: 00:08:18

Pesquisadora - Estou começando a gravar, tá?

P4 - Tá.

Pesquisadora - Preciso que você me fale primeiro o seu nome completo.

P4 - (...)

Pesquisadora - Qual é a sua idade?

P4 - 40 anos.

Pesquisadora - Escolaridade?

P4 - Superior incompleto, cursando.

Pesquisadora - Você faz curso de quê?

P4 - Fiz dois anos de Direito, agora estou me formando em Marketing.

Pesquisadora - Ah, que legal. Onde e com quem você mora?

P4 - Com meus pais, na Zona Oeste.

Pesquisadora - Tá.

P4 - Freguesia.

Pesquisadora - Descreve para mim se você puder, rapidinho, a sua trajetória com drogas. Como começou e como...

P4 - Comecei a fumar maconha com 18 anos. Experimentei. Aí o meu uso contínuo mesmo de maconha foi lá pelos 24 anos. Aí depois fui experimentar cocaína com uns 27 anos. E o uso mais frequente começou com uns 29/30. Com uns 33 já começaram os prejuízos do uso da cocaína com perda de trabalho, problemas familiares, sociais, financeiros, enfim. O crack eu vim usar foi há uns quatro anos atrás, entendeu? Decorrente de não ter a cocaína, porque a minha droga de preferência foi sempre a cocaína. Aí como não tinha e estava fácil o crack, e como foi diagnosticado em mim bipolaridade, entendeu, já fui internado no Hospital das Clínicas. Não sei se por isso ou por outros problemas acabei experimentando, entendeu? Aí me afundei um pouquinho. Meu uso nunca foi contínuo, porque já sabia que era o final do poço. Mas tive problemas com crack.

Pesquisadora - No seu pior período você chegou a usar com que padrão? 
P4 - Ah, de ficar assim uns dois dias na rua. Assim, já me colocando muito em situação de risco com o pessoal de rua. Já vi que estava assim, barra pesada. Cheguei a vender algumas coisas minhas, entendeu? Já estava um negócio bem incoerente, bem sem controle.

Pesquisadora - E você buscou tratamento pela primeira vez quando?

P4 - Olha, eu me internei, Gabriela, foi acho que em 2006. Eu trabalhava em uma construtora, então peguei um dinheiro alto assim e aí tive quase dois começos de overdose. Só na cocaína. Aí me decidi internar porque tava sem controle. Aí eu me internei, se não me engano, foi em 2007. Fiquei dois meses. Saí porque era uma instituição que só visava o lucro financeiro, entendeu? Não tive assistência médica, psicológica, adequada. Aí saí, aí voltei ao uso depois de dois meses. Isso tudo cocaína. Aí depois vim experimentar o crack. Sempre saía, mas às vezes dava umas afundadas de dois dias no crack. Me colocava em situação de risco porque eu ficava realmente com medo. Começou a me dar muita depressão após o uso do crack, que é uma coisa horrível. Depois eu decidi - meu pai trabalha no Emílio Ribas pedi uma ajuda para ele, consegui uma internação de 30 dias lá no Hospital das Clínicas, porque a melhor internação que eu tive foi aonde foi diagnosticada a bipolaridade. Tanto é que ainda estão estudando aqui se tem níveis de bipolaridade e tal. Estão me medicando agora. Mas lá me deu uma ampliada. Fiz testes psicológicos; foi diagnosticado também que o meu Q.I é 120, um pouquinho acima da média, que a psicóloga falou que é de 90 a 100 . E eu tive respostas que eu procurava. Porque o tempo que uso tanto, por que estou fazendo isso com a minha vida? Agora eu consegui, entendeu? Só que o uso, você não consegue, assim, acho que você não consegue mudar a tua vida, tão rápido, dar pulos de um uso frequente de quase 20 anos, uns 15 anos de uso, eu não vou conseguir rapidamente. Então tem as recaídas. E agora estou voltando, não é? Tive que me afastar de trabalho, muito prejuízo.

Pesquisadora - E você consegue pensar, das vezes que você procurou tratamento, quais foram os motivos que te fizeram buscar?

P4 - Financeiro, familiar, pessoal... Sempre pensei por que eu estou me afundando, perdendo muitas oportunidades? Eu já trabalhei em multinacional. E pessoal mesmo, de relacionamentos, família, socioeconômica, de todos os âmbitos que uma pessoa pode perder, eu estava perdendo e me questionando o porquê. E fui atrás de respostas. Eu nunca tive muito problema com Polícia. Só no uso do crack que comecei a frequentar favela, saí totalmente do meu perfil de usuário. Sempre usei com amigos, entendeu? De poder 
aquisitivo normal, não tão baixo. Saí fora. Esqueci deles. Me afundei com pessoas que não eram do meu habitat normal.

Pesquisadora - E aí com essas pessoas que estavam relacionadas ao uso do crack, você teve alguma experiência com Polícia ou só teve medo da Polícia?

P4 - Eu sempre tive um pequeno com conhecimento, leigo, das leis ou dos meus deveres, ou das consequências do que eu estava fazendo. A abordagem policial normal. Já tive várias, mas sem grandes consequências, porque eu nunca fui um usuário que pegava e segurava assim, eu sempre queria sair disso, entendeu? Então eu não ficava com muita droga, entendeu? Distribuía, pegava. Eu sempre tive dinheiro, sempre trabalhei, mas eu nunca fiquei com muita droga em cima. Nada. Como eu já tive dois começos de overdose, então já tinha esse receio de estar usando muito.

Pesquisadora - Então você não me diria que esse contato com a Polícia tenha te incentivado de algum jeito a buscar o tratamento, ou você acha que ajudou?

P4 - Ah, não. Sim. Ajudou sim porque você faz uma reflexão. Aonde eu estou? Que pode acontecer? Olha o que eu estou fazendo com a minha vida. Então, que ponto que eu estou? A situação que eu estou, com as pessoas que eu estou, para estar tendo uma abordagem policial.

Pesquisadora - E das vezes que você foi abordado pela Polícia, você alguma delas estava com droga?

P4 - Acho que nunca pegaram nada em cima. Só sobre o efeito. A droga, se pegaram, acho que um baseado, mas não era comigo, não estava comigo, entendeu? Mas a situação...

Pesquisadora - Para a Delegacia você nunca foi?

P4 - Para a Delegacia eu fui uma vez em um show no Pacaembu. Me pegaram com um baseado e aí me levaram, eu mais um amigo, mas aí eu conversei com o delegado, expliquei a situação e logo após fui liberado.

Pesquisadora - Você tem alguma situação para me contar, que você tenha se sentido diferente de outras pessoas por ser usuário de drogas?

P4 - Olha, pela discriminação social, assim... Eu sempre tive - como posso te dizer, Gabriela? - confiança em mim, entendeu? Por isso eu vim procurar ajuda. Sempre tive um alicerce de família; tenho irmãos com pouca diferença de idade e sempre me questionei: o que estou fazendo com a minha vida? Por que estou seguindo esse caminho? Entendeu? Porque foi se agravando, não é? Com as perdas, entendeu? Aí fui procurar ajuda, fui querer 
saber a resposta do porquê tudo isso estava acontecendo. E a idade vem chegando, vai se questionando até onde vai parar se você continuar.

Pesquisadora - Pelo Fórum, por questões relacionadas a droga?

P4 - Nunca! Nada, graças a Deus!

Pesquisadora - É isso. Obrigada.

P4 - De nada. 


\section{ENTREVISTADO: P5}

Arquivo de Áudio:130717-002

Tempo: 00:09:46

Pesquisadora-Comecei a gravar. Primeiro eu preciso que você me fale seu nome completo. P5 - (...)

Pesquisadora - Cidade?

P5 - São Paulo.

Pesquisadora - Idade.

P5 - Ah, idade? 26.

Pesquisadora - Escolaridade?

P5 - Ensino Médio completo.

Pesquisadora - Você mora com quem?

P5 - Com a minha mãe.

Pesquisadora - Explica para mim um pouquinho a sua trajetória com o uso de drogas. Como começou e com qual droga começou, como evoluiu.

P5 - Eu comecei fumando cigarro com 16 anos. Já bebia, mas sempre, até hoje, socialmente. Do cigarro, com 16 anos, eu experimentei maconha. Daí eu experimentei a cocaína e nesse meio termo, com 16/17 anos na Faculdade eu usei lança, cocaína, menos o crack. Lá eu não usei o crack. E na mesma época da faculdade, mas fora da Faculdade com alguns amigos, eu experimentei o crack e daí em diante, com mais ou menos 18 até hoje os 26 anos, eu tô nessa. Não tenho problema. Nunca tive problema com maconha nem com cocaína, nem com lança, nem com nada. Mas mais ou menos dos 18 anos até os 26 que é hoje, eu continuo, eu estou com problema do crack e eu uso frequentemente.

Pesquisadora - Frequentemente significa quanto?

P5 - Depende da época. Hoje eu falo para você que eu uso de duas a três vezes por semana. Esse ano, vai. Vamos colocar que esse ano de 2013 eu uso de duas a três vezes por semana. Pesquisadora - Por que você acha que você foi procurar drogas? Você acha que teve um motivo diferente no começo e para o crack foi outro? Foi... 
P5 - O começo foi por uma coisa muito besta mesmo: curiosidade. Coincidentemente ou não, o engraçado e irônico da vida é que até meus 15 anos eu não suportava a pessoa que fumava. Se a pessoa acendesse um cigarro, eu saía de perto e me aproximava depois que acabava. Sempre foi assim; nem me incomodava de a pessoa sair, eu saía tranquilamente. E com 16, não vou dizer nem que foi moda, porque nunca foi por modinha, nunca foi por ser bonito, mas sim pelos meus dois melhores amigos - uma era uma amiga e outro um amigo - e eu sempre tava com os dois, ou com um ou com outro. Sempre, os dois sempre fumando e a gente saía e bebia e tal, desde os 16. Então experimentei o cigarro. E aí foi indo. Não sei por qual motivo, talvez pelo próprio vício do tabaco, não sei por qual motivo o cigarro se instalou e ficou. A maconha foi em uma ocasião muito engraçada, no meio da rua, uma coisa muito besta, com 16 anos. "Ah, experimenta, experimenta". Eu experimentei e dei muita risada na primeira vez, eu me diverti muito, foi realmente uma coisa muito legal, muito bacana e devido àquela situação engraçada e legal e gostosa, eu procurei a segunda, a terceira, mas sempre muito esporadicamente. Também por ironia também, eu morava no interior, São Paulo, interior próximo em Mairiporã e com 12 a 13 anos eu me envolvi com pessoas que usavam maconha, pessoas mais velhas, que na época tinham 15 ou 16; eles usavam maconha direto. Eu estava sempre próximo, eu nunca entrava no mesmo ambiente que eles estavam no momento que eles usavam; não tinha curiosidade; não gostava, nada. Então assim, na verdade já envolvido com esse meio desde essa idade. E aí da maconha... Assim, sabe? Sei lá, por estar em roda de amigos, que foram os amigos que eu comecei a usar a cocaína; foram os amigos que eu comecei a usar maconha a primeira vez na minha vida - a primeira vez não. Foi quando eu comecei, não a primeira, mas quando eu comecei realmente a usar - então foram os mesmos amigos de todas as drogas que eu usei e que eu uso, foram com os mesmos amigos. E a cocaína foi em um momento que estávamos todos juntos e sabe quando... Não foi uma coisa de moleque, de desafio. Mas "vamos experimentar? Vamos todo o mundo experimentar junto, vamos, vamos, vamos" e sei lá, não vou te dizer ou recordar o porquê, o motivo. Mas eu simplesmente usei e aí a gente continuou usando de vez em quando. Era uma coisa sempre esporádica, sempre era coisa de duas, três vezes por semana ou uma vez por semana, sempre uma coisa meio controlada entre aspas, e quando eu percebi eu já estava usando sozinho, porque eu estava fazendo faculdade na época; claro, eu não terminei a faculdade, mas eu estava fazendo faculdade e quando eu saía da faculdade para encontrar com eles, eles já estavam - porque o meu amigo ele morava... De final de semana ele ficava sozinho na casa dele, então eu saia da Barra Funda e eu ia até 
o Panamby - eles já chegavam lá... Todos já tinham usado. Então para eu chegar à fé igual a eles, eu fui usando também. Foi assim que eu comecei a usar sozinho e tal. Foi devido a me encontrar com eles.

Pesquisadora - O PROAD foi a primeira vez que você buscou tratamento?

P5 - Foi.

Pesquisadora - E por que você decidiu buscar?

P5 - Ah, por que... O PROAD ou ajuda no geral?

Pesquisadora - Ajuda no geral.

P5 - Começou em um dia de desespero que eu briguei com a minha namorada e ela jogou várias coisas na minha cara - eu não trabalhava na época - eu estava com a vida muito inútil, em um mundo muito fechado e eu me obriguei; ela falou várias coisas na minha cara, me jogou várias coisas na minha cara e realmente eu me senti... Sei lá. Ela jogou a real na minha cara. E aí eu percebi que realmente eu já tinha perdido coisas materiais e namoradas, pessoas, amigos, e que eu realmente precisava de alguma ajuda. Foi quando eu voltei para a minha mãe, depois briga com ela eu contei para a minha mãe o que eu fazia - ela também não sabia - e daí em diante eu fui atrás de um psicólogo; o psicólogo me indicou o PROAD e aí as coisas foram fluindo.

Pesquisadora - Você já se sentiu alguma vez diferente por ser usuário de drogas? P5 - Não. Não.

Pesquisadora - Você já teve alguma experiência com a polícia?

P5 - Uma vez. Devido à droga uma vez mesmo. Foi uma época que eu usava maconha só e uma pessoa parou, simplesmente eu estava parada na porta de um amigo, a Polícia parou e o amigo que estava ao meu lado enquanto nós estávamos esperando o outro descer, estava com maconha dentro do carro, bem pouco no bolso dele e esse amigo que nós estávamos esperando, ele é negro, e quando ele entrou no carro a Polícia estava passando e a Polícia me parou. Quase uma coisa de rotina. Eu estava parado. E aí o meu amigo não jogou fora, não fez nada com aquilo lá e tinha 1.7 grs. de maconha, não tinha nada! É muito pouco. Simplesmente levou a gente para a Delegacia, ele tinha 18 anos, e não deu em nada. Na verdade meu amigo assinou, teve que pagar cesta básica e tal, mas não deu em nada. Eu saí de lá...

Pesquisadora - E essa situação, de alguma forma te fez refletir, pensar no teu estado também?

P5 - Não. Não. 
Pesquisadora - No Fórum, nenhuma experiência?

P5 - Não. Nunca.

Pesquisadora - Então, são basicamente as perguntas...

P5 - Sendo bem sincero, é difícil uma pessoa que usa droga ou que é viciado, refletir. Mesmo passando por momentos difíceis ou por coisas difíceis, é difícil a pessoa parar e refletir no que está fazendo.

Pesquisadora - Por que você acha?

P5 - Porque o vício e a vontade e o êxtase da situação é muito mais forte. Você pode ter um piripaque e você pode... Cansei de ver casos por aí de colegas e de conhecidos, e de colegas, não é? Do próprio PROAD, pessoas que quase amputam a perna, de que quase morreu e de várias coisas assim e nem por isso deixou de usar. Então assim...

Pesquisadora - Então o que você acha que dá o start?

P5 - Para usar?

Pesquisadora - Não. Para buscar ajuda.

$P 5$ - Não sei. Alguns momentos sóbrio. E na verdade eu passo mais tempo da minha vida sóbrio do que pós-uso. Mas, é um dos momentos que você vê as pessoas sorrindo na rua, que você vê as pessoas vivendo o quotidiano normal, uma rotina natural, gostosa, normal... Alguns momentos que você abre fotos e vê viagens e vê lugares que você pode ir ver; porque quando você está nesse mundo de drogas, você não faz nada disso. Você não viaja, você não sai, você não tem vida social... Se você realmente é uma pessoa viciada e que não sai e que é realmente uma droga, você não tem essa vida social. E eu me afastei de todos os meus amigos, inclusive melhores amigos, devido à droga. Demais. Eu me tranquei em um mundo que meu mundo social era a minha mãe e a minha namorada. Ninguém, ninguém, ninguém mais do que elas duas. Então, assim, graças a Deus hoje eu estou trabalhando e tal. Tem dois meses quase que estou trabalhando, mas quem é viciado não pode ter piripaque; sei lá, é difícil. Não sei explicar qual é o motivo de que você procura uma ajuda. Mas uma coisa eu acredito - eu falo por mim e por visões de outros - não é um..., ajuda, pode ser que você mude, pode ser um bom sinal, mas não necessariamente um piripaque ou uma situação que você vê que alguém morreu, sei lá, qualquer coisa que aconteceu de grave devido à droga, que você vai deixar de usar. Nem assim você deixa de usar.

Pesquisadora - Entendi. Então, está bom. Obrigada.

P5 - Imagina. 


\section{ENTREVISTADO: P6}

Arquivo de Áudio: 130724-001

Tempo: 00:12:38

Pesquisadora - Comecei a gravar. Primeiro eu preciso que você me fale seu nome completo. P6 - Meu (...)

Pesquisadora - Fala mais devagarzinho.

P6 - (...)

Pesquisadora - É muito legal o seu nome!

Pesquisadora - Sua idade.

P6 - 21 anos. Eu nasci em 28 de março de 1992.

Pesquisadora - Você estudou até que série?

P6 - Eu estava cursando o $3^{\circ}$ ano, mas eu não terminei.

Pesquisadora - Onde você mora e com quem?

P6 - Eu moro em uma cidade chamada Colíder, Mato Grosso. E moro com meu pai.

Pesquisadora - Só o seu pai?

P6 - Não, meu pai e meus irmãos.

Pesquisadora - Você tem quantos irmãos?

P6 - Eu tenho na verdade cinco, mas só que as duas é casada e ficou só os que é menor lá com meu pai.

Pesquisadora - Entendi. Me conta um pouquinho como é que foi essa história com o uso de drogas. Como você começou? Com que idade? Qual foi a sua primeira droga e como evoluiu?

P6 - Então, eu comecei a usar cigarro primeiro, com 11 anos de idade. Aí com álcool e depois com 12 anos comecei a tomar bebida alcóolica, comecei a tomar álcool e com 13 anos eu experimentei a maconha. Aí de lá foi só me matando. Aí com uns 15 anos eu comecei a usar cocaína, que era a pasta base que é cocaína e aí com 17/18 anos comecei a usar pedra até uns 40 dias atrás.

Pesquisadora - Entendi. E você é a primeira vez que você procura tratamento ou você já procurou antes?

P6 - Não. Já procurei antes. Eu fui internado uma vez, duas vez (sic).

Pesquisadora - Tudo por causa do crack? 
P6 - É.

Pesquisadora - E por que você procurou tratamento das vezes que você procurou?

P6 - Ah, porque eu não aguentava mais viver daquele jeito lá. Eu já estava virando mendigo na verdade.

Pesquisadora - De que jeito você estava vivendo?

P6 - Ah, vivia na rua, todo sujo, eu não tinha... Eu era desleixado, não almoçava, não comia... E aí só vivia na rua pedindo, mentindo, manipulando, roubando.

Pesquisadora - Isso aconteceu só por crack ou já tinha acontecido antes?

P6 - Não, foi só com o crack mesmo que eu comecei a fazer isso daí que eu falei que era mentir, roubar... Só não matei.

Pesquisadora - Entendi. E a decisão de buscar o tratamento, foi sua ou alguém conversou com você?

P6 - Não. Foi minha, porque quando tinha uns - ano passado mesmo - quando eu tinha 19 anos, minha primeira família falava em me internar; só que eu não queria, não é? Por que... Eles não sabiam... Eu não queria, não é? Aí no ano passado eu não conseguia mais, levantava muito magro, ainda por cima estava muito magro, estava entrando em depressão, assim, eu acredito para mim também. Porque eu passava dias sem voltar para casa, eu voltava muito... perdido, não é? O que eu fazia, o que eu fiz, as coisas que eu fazia...

Pesquisadora - E você falou para mim que você procurou tratamento mais de uma vez. Então você recaiu?

P6 - É e tal. E aí eu, ano passado eu fiquei quatro meses internado em uma unidade terapêutica aí depois eu saí, fiquei mais dois mês (sic), aí eu caí o ano passado, foi no ano passado. Depois de seis meses eu comecei a usar de novo.

Pesquisadora - E aí você decidiu buscar tratamento de novo?

P6 - Não. Aí depois que eu comecei a usar de novo, aí fiquei internado, e aí eu pedi de novo ajuda, porque já estava perdendo as minhas coisas, e eu não via a confiança que eu tinha da minha família também. E eu estava perdendo. E os amigos também, não é? Amigos? Eu não tinha amigos. Era... pelo que havia... que coisa junto comigo não é amigo.

Pesquisadora - Entendi. Você já se sentiu diferente das outras pessoas por usar droga? P6 - Diferente? Não. Eu não me sentia diferente, não. Às vezes eu me sentia..., não sei se era diferente, porque acho que a pesar de... A sociedade tem um tipo de preconceito com a pessoa que usa não é? Esse tipo de droga aí.

Pesquisadora - Que tipo de preconceito? 
P6 - Ah, eles não gostam, né, de estar junto, não sei, ele tem medo de ser roubado. Uma coisa assim, eu acho.

Pesquisadora - E você acha que tem algum motivo?

P6 - Porque eu uso droga, não é? Eu acredito que é isso aí.

Pesquisadora - Mas você acha que está certo esse pensamento, esse medo, ou você acha que é exagerado?

P6 -Não. Eu acho que é exagerado, mas eu comigo, eu vejo assim, eu também me sinto assim meio desconfiado que a pessoa venha fazer alguma coisa e... De deixar essa pessoa entrar dentro de casa e me roubar alguma coisa. Porque eu já passei por isso e a pessoa faz, não é? Eu me sentia diferente, eu não me sentia diferente não. Às vezes eu me sentia, não é? Eu me sentia..., que eu podia fazer isso; eu usava drogas e ele não, a outra pessoa não. É isso.

Pesquisadora - Você já teve alguma situação com a Polícia? Já passou por alguma situação com a Polícia, relacionada a drogas?

P6 - Já.

\section{Pesquisadora - E como foi?}

P6 - Não sei se relacionada à droga. Eu acho que foi relacionada à droga, foi quando levei um tiro. Eu tinha uns 16/17 anos, quando eu estava fazendo 17 anos. Mas a intenção não era acertar em mim, era para acertar em outra pessoa, que era...

Pesquisadora - Mas o que estava acontecendo? Como foi a situação?

P6 - Estava tendo uma festa lá na minha cidade que era... Todo ano tem a Festa Junina, não é? E tem em vários lugares também, nas escolas, na praça, na avenida, sempre tem. E estava tendo em um ginásio lá. Aí um traficante chamou para nós fumar maconha, eu e ele; chegou em mim e perguntou se eu queria fumar; aí eu fui e falei: "Vamos fumar. Vamos fumar". Ele chamou eu e eu chamei mais uma pessoa; aí nós fomos lá na praça onde tem esse prédio desse ginásio; aí nós tava no meio da pracinha e começou a rolar. Aí começou a chegar gente; pessoa que conhecia ele e queria fumar também. Aí estava vindo uma pessoa, tipo... na praça tem várias entradinhas, ficava uma entradinha no meio da praça; aí estava eu entrando no meio da praça, foi quando ele... Eu não sabia o que estava acontecendo, o motivo dele atirar nas pessoas, aí ele tirou a arma e foi para em cimão desses cara aí, aí quando chegou perto desses caras ele atirou, aí acertou tipo no ombro dele assim, de raspão e ele abaixou; aí veio para cima de nós e o cara que levou o tiro veio para cima de nós; aí esse cara foi lá e atirou no meio a primeira vez. Era uma escada assim que vinha subindo e aí na escada nós estava no alto; aí quando atirou não acertou, não acertou ninguém e todo o mundo abriu. Aí 
eu fui tentar abrir através de umas pedras e aí foi quando ele atirou a terceira vez. Quando eu vi assim, o cara estava do meu lado, assim, tipo..., do meu lado não, perto de mim, como estou longe assim, uns dois metros, uns três metros. E eu tentando correr e ele atirou, e quando atirou ele acertou no braço dele e por acidente acertou na minha perna. Aí na hora eu não senti, saí correndo. Na hora, com o sangue quente eu não sentia. Depois que eu fui sentir que estava saindo sangue, aí me levaram pro hospital. Meu pai ficou muito bravo. Aí chegou a Polícia, o delegado e me perguntou o que estava acontecendo e aí eu falei pra ele. Eu falei que eu não vi quem... Não, ele perguntou quem tinha atirado, eu falei que não sabia, aí foi que era pra mim ir na delegacia o outro dia. Aí eu fui; aí de novo ele perguntou se eu sabia quem atirou. Eu falei que não sabia. Se eu conhecia ele, não. Esses caras também... Eu conheço. Foi isso que aconteceu.

Pesquisadora - Mas nunca tomou um enquadro para procurar droga...?

P6 - Ah, sempre os policial me enquadrava eu quando eu estava na praça, na rua, eles paravam eu para perguntar o que eu estava fazendo e mandavam eu embora. Só nunca... Ah, já também fui preso roubando também.

Pesquisadora - E teve a ver com droga?

P6 - Ah, essa aí foi, porque estava roubando para usar droga. Isso foi recente.

Pesquisadora - E como aconteceu? Você estava roubando onde? Como que eles te abordaram?

P6 - Então, fui roubar uma casa, eu e uns colegas; sempre roubava casa, mas não chegava com arma assim. Era tipo..., furto mesmo. As pessoas dormindo de noite e eu ia de madrugada, não me pegavam. E aí uma vez eu fui pegar uma casa e pegamos um vídeo game, uma Playstation 1, 2, DVD, câmara digital, nós pegamos. Tinha costume de pegar... Consumimos ele, nós pegamos droga, aí no outro dia, eu não sei quem foi que o dono foi lá e conseguiu ver quem tinha roubado. E o dono sabia que era nós. Aí pela cidade ser pequena também, não era muito grande, aí foi na Delegacia registrar queixa e no outro dia o policial foi lá em casa lá, chamar eu para vir, que precisava falar com o delegado lá, que não sabia o que era. Aí eu fiquei. Aí o delegado começou a perguntar dos videogames, das motos. Se eu sabia de umas motos que tava sendo roubadas na rua. Aí já queria falar pra mim falar onde era as boca, as biqueira, aí eu não falei não. Aí eu fiquei umas três hora lá, entrei lá 11h, saí de lá umas 4h da tarde. Minha família foi lá me tirar, meu pai foi lá me tirar, meu irmão.

Pesquisadora - E algumas vezes essa experiência com a Polícia, o fato de ter ido para a Delegacia, ou de ter tomado o tiro, te fez pensar em parar de usar, em procurar ajuda? 
P6 - Não. Mas... Não. Não pensava não em pedir ajuda. Porque eu tava em uso, né? Aí eu não pensava em parar.

Pesquisadora - Não teve nada a ver com isso.

P6 - Não. Só depois que eu entrei em recuperação que eu fui ver que aquele tiro podia acertar em outro lugar e podia estar morto, e aí Deus me deu uma chance. Uma chance não, o poder superior de Deus e Nossa Senhora, pra mim ficar livre.

Pesquisadora - Entendi. É isso. São essas as perguntas. Muito obrigada. 


\section{ENTREVISTADO: P7}

Arquivo de Áudio:130807-001

Tempo: 00:12:27

Pesquisadora - Então, me fala seu nome.

P7 - (...)

Pesquisadora - Quantos anos você tem?

P7 - 26 anos.

Pesquisadora - Você mora com quem?

P7 - Com meu esposo, Luiz.

Pesquisadora - Vocês são casados há quanto tempo?

P7 - Um ano vai fazer.

Pesquisadora - Que bom, vai fazer festa.

P7 - Não...

Pesquisadora - Você estudou até que ano.

P7 - Estou estudando. Voltei a estudar, estou fazendo a $8^{\text {a }}$ Série.

Pesquisadora - Ah, que legal. Você voltou a estudar há quanto tempo?

P7 - Vai fazer seis meses.

Pesquisadora - Você está animada?

P7 - Tô.

Pesquisadora - Eu queria que você me contasse um pouquinho como começou essa história com droga. Quando você começou a usar? O que você usou primeiro? Como evoluiu... P7 - Eu morava com a minha tia, saí de casa para morar com as minhas irmã.

Pesquisadora - Por que você morava com a sua tia?

P7 - Porque meu pai e mãe são falecidos. Minha mãe faleceu eu tinha seis anos, meu pai eu tinha nove. Meus pais também eram dependentes do back e eles morreram por causa da AIDS. Porque usavam agulha, né? Eu comecei a usar droga com 17 anos. Comecei a fumar maconha e depois cocaína. Aí eu amiguei, tive meu filho Kevin e aí eu sosseguei um pouco. Aí depois eu terminei com ele, que ele me traiu, e eu tive uma depressão. Aí deixei meu filho com a mãe do meu ex-marido. Aí ela cuidou dele pra mim até agora, né? Aí eu comecei, de uns três anos pra cá a usar crack. Eu usava umas 80 pedras por dia. O consumo era bem alto. Meu marido que me resgatou. Aí a gente começou... Ele me falou da Igreja e tudo. Aí 
comecei a ir para a Igreja, dei o primeiro passo, né? E aí voltei a fazer o tratamento na PROAD.

Pesquisadora - Entendi. Você já tinha tentado uma vez?

P7 - Já.

Pesquisadora - Quando foi a primeira vez?

P7 - Vai fazer dois anos atrás.

Pesquisadora - E por que você veio a primeira vez?

P7 - Porque eu tava grávida, do Júlio, que está com a minha irmã; e eu fiquei até os quatro meses dele; aí eu não aguentei e recaí. Eu achei que tava forte o suficiente pra poder sair, andar. Hoje em dia eu já não ando sozinha. Não consigo, eu tenho medo de andar sozinha e de repente me dar uma vontade e eu não ter ninguém pra falar que a vontade... Não ter alguém para me apoiar. E meu marido fica comigo 24h, vai me buscar, me traz, e quando meu filho está aqui, o mais velho, eu tenho mais segurança, porque aí nem tenho sono nem nada.

Pesquisadora - Porque você fica com ele e...

P7 - Aí não tenho.

Pesquisadora - Se você visse como você muda, quando você fala dele.

P7 - É.

Pesquisadora - É bonito de ver.

P7 - (risos) E o outro não vejo ele faz um ano e oito meses. Que a minha irmã não deixa ver.

Pesquisadora - E por que ele foi ficar com ela?

P7 - Porque eu fazia o tratamento aqui no PROAD, e minha irmã...

Pesquisadora - Se você não quiser me falar disso, me diz, tá?

P7 - Tá. É que eu estou emocionada, né?

Pesquisadora - Mas você vai até onde você quiser.

P7 - Aí minha tia já tinha falado pra ela que eu não podia sair sozinha e tudo; e ela me deu $\mathrm{R} \$ 20,00$ e eu acabei usando droga e eu deixei meu filho e não voltei mais. Deixei com ela. E agora que eu estou bem e tudo, ela não quer deixar pegar ele, nem ver.

Pesquisadora - E você já está sem usar?

P7 - Tô.Um ano.

Pesquisadora - Um ano já sem usar. E se você tivesse que escolher um motivo pelo qual você acha que você procurou o tratamento, você diria que foi por quê? 
P7 - Por quê? Por mim. Pra mim voltar a ter a minha vida de novo. Porque aquela vida rotina, que você acorda pensando na droga, dorme pensando em droga e têm as pessoas que por causa da droga querem te fazer alguma coisa, entendeu? O quer fazer algum mal por causa do efeito da droga, então você não dorme direito; você não vive direito. Hoje em dia eu sei o que é dormir, sabe? Engordei 30 quilos.

Pesquisadora - Que beleza. Mas, eu estou te perguntando por que depois vou te fazer outras perguntas. Mas você me disse "ah, o meu marido me resgatou e então você se apaixonou e aí te apresentou a Igreja". Então, se você pensasse assim: "o quando que você olhou para você e falou: olha, preciso, por mim, procurar o tratamento,". Que situação da sua vida que deu esse estalo?

P7 - Meu marido conversando comigo, me falou: dá o primeiro passo. Porque ele é exdependente também, do crack e ele foi para a clínica e tudo. Eu não fui para clínica, vim para cá. E eu vi que tinha jeito, sabe? Que tinha uma solução que dá pra mudar. E quando você vê uma pessoa que está fazendo tratamento e consegue, você vê de outra maneira, sabe? Pesquisadora - Você acha que a mídia, enfim ou que as pessoas vendem essa ideia de que o usuário de crack nunca vai abandonar a droga?

P7 - Ah, eu acho errado.

Pesquisadora - Então, mas você acha que isso acontece? Foi isso que ele te fez ver diferente?

P7 - Ver diferente. Porque assim, falam que é muito difícil. É difícil; eu mato um leão por dia, né? Mas não é aquele bicho de sete cabeça. No começo, as partes piores. Os primeiros seis meses são os piores. Depois vai passando. Porque antigamente o pessoal me chamava pra usar, mesmo eu parando. Hoje em dia o pessoal pede para mim orar por eles.

Pesquisadora - Entendi.

P7 - Porque eles me veem como exemplo.

Pesquisadora - Quando você começa a se afastar das drogas os amigos ainda...

P7 - Continua. Há os que te perseguem mais ainda. Chama, convida, porque sabem que você parou e você não vai querer usar. E você não vai gastar o seu dinheiro, porque você vive correndo atrás de dinheiro. Pede na rua, faz o que for. Ajuda a reciclar..., eu fazia isso. E isso é uma maneira que eles fazem para a gente voltar àquela rotina, então eles continuar usando droga também, junto com a gente. E hoje em dia eles não me convida mais.

Pesquisadora - Teve alguma vez que você se sentiu diferente das outras pessoas por usar droga? 
P7 - Ah, a gente sente. Se sente um lixo, assim.

Pesquisadora - Por quê?

P7 - Porque a gente fica um lixo. A gente fica sem tomar banho. As pessoas discriminam você, de ficar perto de você. Se a gente tá sentada em um lugar, as pessoas falam: “Ah, aquele bando de drogados".

Pesquisadora - E você acha que as pessoas têm razão?

P7 - Com certeza. Eu acho. Porque dá..., hoje em dia você..., hoje, aqui hoje, eu não tô usando mais, quando eu vejo uma pessoa assim, eu fico com dó. Mas outra pessoa que não usa, não entende o lado daquela pessoa. Que ela precisa de uma ajuda e precisa entender que ela precisa de ajuda. Que o mais difícil é você saber que você precisa de ajuda, porque é tão chato você precisar de ajuda. É mais fácil você ajudar do que você precisar de ajuda.

Pesquisadora - Entendi. E será que se as pessoas começassem a olhar para os usuários como pessoas que precisam de ajuda, seria mais fácil deles chegarem a essa conclusão?

P7 - Acho que capaz dele nem de... De conseguir fazer mais o tratamento, sabe? Porque muita gente falava: “ah, clínica não dá certo. Já fui pra três ou quatro clinicas - eu ouvia falar - e nunca deu certo, porque nunca acaba”. Sabe? E eu nunca fiz clínica e consegui.

Pesquisadora - Entendi. Você já teve alguma experiência com a Polícia?

P7 - Enquadras, várias.

Pesquisadora - Em vários enquadros?

P7 - Vários.

Pesquisadora - E como foi a experiência?

P7 - Esculachando, não é? Batem, humilham, xingam de tudo o que é nome e falam que a gente é um lixo; que a gente é raça que não podia viver... Essas coisas assim.

Pesquisadora - Eles costumam levar para a Delegacia ou eles fazem esculacho na rua?

P7 - Esculacha, bate e deixa lá.

Pesquisadora - Não fazem nada?

P7 - Nada.

Pesquisadora - Para a Delegacia nunca te levaram?

P7 - Nunca. Mas bater, eles me bateram muito. Eu tenho hematomas; vários hematomas.

Pesquisadora - Você tem marcas?

P7 - Marcas de Polícia.

Pesquisadora - Você chegou a ficar na rua com o tempo?

P7 - Morei na rua. 
Pesquisadora - Quanto tempo?

P7 - Dois anos.

Pesquisadora - E quando você morou na rua...

P7 - Vários polícias. Apesar que tinha polícia, aqueles azulzinhos, não é polícia...

Pesquisadora - Guarda Civil.

P7 - Eles já me chamaram para o abrigo, esses negócios assim, pra clínica; mas eu, como já ouvia falar muito que clínica não dava certo, eu achava que nunca ia conseguir.

Pesquisadora - E da Polícia, você já ouviu alguma vez que você não tinha conserto?

P7 - Que não tinha conserto? Ah, falava que a gente era um lixo. Que por causa da gente que eles estavam..., que a gente estava ajudando o crime e que não sei o quê.

Pesquisadora - Na época que você morou na rua, você ficava junto com outros usuários?

P7 - É.

Pesquisadora - E alguma vez algum agente de saúde chegou até você?

P7 - Não.

Pesquisadora - Você só teve contato com a Polícia?

P7 - Com a Polícia.

Pesquisadora - Nunca ninguém chegou só para te oferecer tratamento?

P7 - Ajuda? Não! Só esse rapaz da Guarda que foi uma vez só.

Pesquisadora - Entendi.

P7 - Ele fez aquele negócio, um arrastão mesmo. Acho que foi bastante gente. Mas depois de um mês voltou todo o mundo.

Pesquisadora - Entendi. Você morava onde?

P7 - Eu ficava embaixo do viaduto da Sacomã.

Pesquisadora - E alguma vez, quando você teve uma experiência dessas com a Polícia, e apanhou, alguma vez esse momento te fez pensar que você devia abandonar a droga?

P7 - Não, dava mais vontade ainda.

Pesquisadora - De usar?

P7 - É.

Pesquisadora - Por quê?

P7 - Porque ficava revoltada. E a droga alivia, né? Ela dá a ilusão na gente que alivia. Mas ela acaba piorando, porque a gente vai empurrando com a barriga e fica naquele círculo vicioso. 
Pesquisadora - Mas e se você pudesse dizer de você, assim, sobre essa atuação da Polícia, se você tinha medo; se você tinha raiva; você...

P7 - Raiva!

Pesquisadora - Você escolheria qual sentimento? Raiva. Medo não?

P7 - Antigamente quando via um policial que era morto, eu falava: ainda bem, por que... Hoje em dia não. Hoje como tô indo para a igreja e o meu marido também; policiais têm família e depois eu comecei ver pelo lado deles também, que eles têm família, que eles são ser humano e dói também, o machucado deles dói na gente. Aí eu fui percebendo que não pode ter raiva.

Pesquisadora - E você acha que você teria procurado tratamento se tivessem te oferecido antes? Se tivessem tentado te ajudar antes?

P7 - Se eu tivesse visto que alguém deu certo, eu teria.

Pesquisadora - Teria. Você precisava ver uma história que deu certo.

P7 - É.

Pesquisadora - ÚItima pergunta. Alguma vez você teve medo de procurar o tratamento por ter medo de ser punida ou de apanhar da Polícia, alguma coisa assim?

P7 - Não.

Pesquisadora - Medo de ir a um Posto?

P7 - Não.

Pesquisadora - Mas nunca foi também.

P7 - Nunca fui.

Pesquisadora - Só veio para cá?

P7 - Só vim para cá.

Pesquisadora - Nada assim, nunca procurou nada do Estado, CAPS...?

P7 - Não.

Pesquisadora - Por que essa escolha?

P7 - Aqui? Porque aqui eu já conhecia.

Pesquisadora - Então, mas a primeira vez que você veio para cá, por que foi?

P7 - Porque fiquei internada no amparo maternal aí eles me indicaram o PROAD.

Pesquisadora - Então você nunca pensou em ir ao Caps.

P7 - Nunca pensei.

Pesquisadora - E já soube de alguém que procurou o CAPS?

P7 - Ah, o pessoal daqui e me falou que é legal. 
Pesquisadora - É? Que bom! Obrigada.

P7 - De nada. 


\section{ENTREVISTADO: P8}

Arquivo de Áudio:130807_002

Tempo: 00:21:23

Pesquisadora - Comecei a gravar. Me fala seu nome completo.

Sr. Paulo - (...)

Pesquisadora - Quantos anos você tem?

Sr. Paulo - Trinta e cinco.

Pesquisadora - Você mora com quem?

P8 - Com a minha mãe, atualmente.

Pesquisadora - E você estou até que idade?

P8 - Até... Eu parei de estudar com 18 anos. Depois voltei e agora estou fazendo faculdade.

Pesquisadora - Ah, que bacana. Faculdade de quê?

P8 - Estava fazendo Engenharia e agora troquei para Licenciatura em História.

Pesquisadora - Acho que você melhorou. Faz para mim um resumo de como começou a sua relação com drogas. Então que idade você começou, com que droga você começou a usar? Conta para mim a sua história.

P8 - Acho que foi em volta de 12 para 13 anos, com solventes, cola de sapateiro...

Pesquisadora - Mas como isso? Por causa dos amigos? Em que situação?

P8 - Foi incentivo. Assim, não incentivo, mas modismo, em experimentar. Mas eu já tinha histórico familiar de uso de drogas.

Pesquisadora - Quem usava?

P8 - Meu pai, meu irmão mais velho e tive também primos e tal.

Pesquisadora - E era o quê? Usavam o quê?

P8 - Maconha, cocaína.

Pesquisadora - Na sua frente?

P8 - Não, não na minha frente.

Pesquisadora - Mas você sabia?

P8 - Sabia. Eu comecei a usar depois que o meu irmão morreu.

Pesquisadora - Seu irmão morreu com que idade?

P8 - Morreu com 22 anos.

Pesquisadora - Que novo! 
P8 - De HIV, por droga injetável.

Pesquisadora - Entendi.

P8 - Tomava cocaína injetável. Aí eu não sei se isso também influenciou no caminho de experimentar droga. Não sei se alguma coisa psicológica. Ainda não descobri isso.

Pesquisadora - Mas aí você passou do solvente para cocaína já ou teve alguma coisa antes? P8 - Não. Foi já...

Pesquisadora - Direto?

P8 - Direto.

Pesquisadora - De que jeito você usava? Injetável também ou inalava?

P8 - Eu inalava e logo em seguida, com uns 14 anos comecei, experimentei o crack, gostei. Com 16 para 17 anos fui internado a primeira vez.

Pesquisadora - Você quis ser internado ou foi contra vontade?

P8 - Não. Eu quis. Eu sempre busquei ajuda, sempre quis.

Pesquisadora - E o que te motivava a buscar ajuda? O que você pensava que falava "não, tem que melhorar?"

P8 - Eu me sentia muito depressivo. Muito mal. Hoje eu entendo, porque eu tenho transtorno bipolar, então a droga me levava muito, mas depois me deixava muito depressivo.

Pesquisadora - Entendi.

P8 - Por conta até de não querer sair de casa, só me esconder, me isolar. Então eu sempre busquei ajuda.

Pesquisadora - E você ficou quanto tempo àquela época, internado?

P8 - Eu fiquei uns 24 dias.

Pesquisadora - E aí? Como foi a experiência?

P8 - Foi uma experiência um tanto traumática?

Pesquisadora - Por quê?

P8 - Eu fui para uma clínica evangélica, e aí... Lá não queria fumar, não queria ler a Bíblia, não queria assistir televisão. Aí eu abandonei o tratamento; não tinha tratamento medicamentoso também...

Pesquisadora - Mas você abandonou por causa dessa severidade de não poder fazer nada, ou teve outra razão?

P8 - Ah, distância da família também. Porque na realidade, eu fiquei em Santos. Minha família ficou em São Paulo e teve uma visita, eles não foram e eu meio que por birra, eu saí. Pesquisadora - E por que eles não foram? Você sabe? 
P8 - Não.

Pesquisadora - Nunca perguntou?

P8 - Nunca quis saber.

Pesquisadora - Entendi. Nossa! Eu ia querer super. Bom, já perguntei quais foram os motivos que te fizeram buscar tratamento e você falou desta foi vez. E aí, depois desta primeira vez, que você tinha $16 / 17$ e ficou até os 24, diz como foi essa história de droga/tratamento.

$P 8$ - Então, quando eu saí dessa clínica, eu já..., quando eu voltei eu não procurei mais o crack. Porém, continuei usando álcool e cocaína. Isso aí durante muito tempo. Sem tratamento nenhum.

Pesquisadora - Mas você achava que estava sobre controle.

P8 - Teoricamente sim. Consegui fazer um curso de Auxiliar de Enfermagem; fui trabalhar no Incor. E trabalhava assim: uma vez por mês eu usava droga e ficava três, quatro dias de cama, em depressão. Aí voltava, voltava a trabalhar, até que chegou um tempo que eu não suportei e fiquei um quarenta dias sem aparecer no hospital. Aí saí desse hospital. Não fui nem mandado embora. Eu pedi para ser mandado embora. A minha chefe queria me ajudar, mas eu não aceitei a ajuda dela.

Pesquisadora - Por quê? Você acha que não...

P8 - Porque eu ainda achava que eu tinha controle sobre a droga. Não tinha essa visão que eu tenho hoje que a era a droga que me dominava e não eu que dominava a droga. Então aí eu pedi para ela me mandar embora. Me mandou embora. Depois... Aí eu casei, antes disso, depois eu casei, tive minha filha que hoje tem 14 anos. E fui levando a vida assim, entre esses altos e baixos, até... Até por volta de uns 24 anos mais ou menos. Aí eu comecei a buscar tratamento psiquiátrico, não?

Pesquisadora - Por quê? O que aconteceu que te deu esse estalo?

P8 - Então... Antes disso eu tive um acidente de moto muito sério. Tive uma parada cardíaca e respiratória durante a cirurgia, devido à cocaína. E isso aí foi me despertando esse outro lado para buscar ajuda. E minha filha também, né?

Pesquisadora - Ela sabe?

P8 - Sabe.

Pesquisadora - Foi você que contou?

P8 - Foi. Foi, em uma das primeiras internações eu cheguei para ela e contei que eu estava indo me internar por conta do uso de drogas e tudo... 
Pesquisadora - Entendi.

P8 - E ela sempre me apoiou, sempre me ajudou.

Pesquisadora - E aí depois desse acidente então ficou essa busca de tratamento... E você me disse que quando você saiu desse primeiro você não buscou mais o crack. Ficou na cocaína e no álcool. E quando que o crack voltou para a cena?

P8 - Não é que ele ficou esquecido. Às vezes eu usava, mas usava pouca quantidade de crack e grandes quantidades de cocaína. Então eu não ficava assim, usando o cachimbo, essas coisas. Então eu fazia o mesclado, que a gente chama, mistura com a maconha, com tabaco...

Pesquisadora - E fumava desse jeito.

P8 - E fumo. Então eu conseguia controlar, teoricamente, eu controlava. Mas a cocaína sempre estava em primeiro lugar.

Pesquisadora - E até hoje você está sem usar? Ou não?

P8 - Agora eu estou... Têm uns 10 dias que eu não...

Pesquisadora - Legal. E aí, até esses 10 dias passados, ainda a cocaína é a sua preferida?

P8 - Então. O ano passado eu comecei a usar o crack com muita intensidade. Estava usando em torno de 10 a 15 pedras por dia. Eu emagreci uns 20 quilos.

Pesquisadora - Foi rápido então que você emagreceu, não é?

P8 - Foi. Em questão de 2 meses eu emagreci 20 quilos. Aí tive... O médico desconfiou que eu estava com tuberculose, estava tendo os sintomas de tuberculose. Eu emagreci meio que muito rápido; sudorese noturna. Eles estavam achando que eu estava com tuberculose. Aí foi... Deu negativo e tudo, né? Aí eu cheguei aqui no PROAD.

Pesquisadora - Foi indicação do médico ou você que achou o PROAD?

P8 - Não. Todos os tratamentos que eu fiz, minhas internações, tudo fui eu. Nunca ninguém fez nada por mim. Nunca nenhuma das minhas ex-mulheres, mãe, nem ninguém. Sempre fui eu que ...

Pesquisadora - Foi você sozinho...

Pesquisadora - E por que você acha que nesse último ano você começou a usar o crack mais intensamente? O que você acha que mudou? Porque você me disse que tem um histórico mais próximo com a cocaína do que com o crack, aí, de repente, esse último ano vira, dá uma mudada nesse padrão de uso do crack. Você consegue pensar o motivo ou só porque sim? 
P8 - Não. Tem motivo. A qualidade da cocaína piorou. O acesso ao crack aumentou. Então, eu conheço muitas pessoas que usavam só cocaína e agora usam só o crack.

Pesquisadora - Entendi. Bastante gente migrando.

P8 - Migrando. Porque há dez anos atrás, uma grama de cocaína custava 10 URVs; na época que vidou o Real. Então eram 10 URVs...

Pesquisadora - É. 10 dinheiros, vai.

P8 - É. R\$ 10,00, mas era um outro valor de dinheiro. Era um valor, sei lá, na moeda de hoje, deve ser uns $\mathrm{R} \$ 50,00, \mathrm{R} \$ 60,00$ ou mais até. Então é caro a cocaína. Mas era uma cocaína diferente da que continua custando $\mathrm{R} \$ 10,00$ hoje, que não satisfaz à pessoa, que não "dá barato". E o crack, ele dá o "barato", entre aspas.

Pesquisadora - Entendi. Mas no fim das contas você acaba gastando quase o mesmo dinheiro porque...

P8 - Ou mais. Que a cocaína você ainda limita o uso. Você chega um ponto que você não consegue mais usar.

Pesquisadora - Por quê?

P8 - Porque você começa a passar mal. Você sente o corpo...

Pesquisadora - Reclamando?

P8 - Reclamando e reagindo contra...

Pesquisadora - E o crack vai?

P8 - O crack você usa dias e dias. Vira...

Pesquisadora - E todo mundo sente assim?

P8 - Sim.

Pesquisadora - Você já se sentiu diferente das outras pessoas por ser usuário? Já sentiu que as pessoas te olham diferente?

P8 - Discriminação?

Pesquisadora - É.

P8 - Sim. Bastante. Até com os próprios usuários.

Pesquisadora - Por quê? Me explica essa situação.

P8 - Porque quem usa crack é discriminado entre os usuários. Entre os traficantes. Não são pessoas de confiança.

Pesquisadora - Entendi. Usuário de crack não merece confiança.

P8 - Não merece. 
Pesquisadora - Você já teve alguma situação que você pode me descrever? Que você percebeu, por exemplo, ainda entre os usuários, que eles te veem de um jeito diferente porque você usava crack e eles não?

P8 - Sim. Até na própria favela, às vezes... Vai pegar o cracke a pessoa fala: "pô, por que você está usando crack? Você usava cocaína e agora vai ficar usando pedra? Isso é coisa para nóia”. Então, é bem frisado esse aspecto de usuário de crack como uma pessoa que... Como é que eu vou te dizer?

Pesquisadora - É uma pessoa de uma espécie pior, vai. Estou certa?

P8 - É.Dentre os usuários ele é um...

Pesquisadora - Está mais para baixo?

P8 - É a ralé.

Pesquisadora - Entendi. E das pessoas, dos não usuários, também percebe essa diferença ou não? Eles, enfim, “é usuário de droga...”.

P8 - É, o usuário de droga em geral.

Pesquisadora - E como é a reação das outras pessoas com o usuário de drogas? É preconceituosa?

P8 - Pessoas que não usam? Sim. Bastante.

Pesquisadora - Por que você acha? Como você vê esse preconceito?

P8 - Eu vejo até dentro da própria família. Parentes que não entendem o problema com o vício.

Pesquisadora - Entendem como o quê?

P8 - Entendem como vagabundagem, com sem-vergonhice. Não é assim. A pessoa tem é... Eu acredito eu que tenho uma predisposição ao vício e é uma coisa muito forte. É uma necessidade que você tem de usar, né?

Pesquisadora - Em resumo, se você pudesse escolher entre usar ou não, se você tivesse escolha, você não escolheria não?

P8 - Sim.

Pesquisadora - Tá. Agora vem a pergunta. Você já teve alguma experiência com polícia? P8 - Várias.

Pesquisadora - Como foram?

P8 - Eu como sou branquinho, tenho uma boa aparência e tudo, nunca... Nunca não, não vou dizer 'nunca', não fui tão esculachado pela Polícia, né? Mas já tomei tapa na cara, já tomei murros; já me ameaçaram de me matar várias e diversas vezes. 
Pesquisadora - E a Polícia costuma levar para a Delegacia depois que faz a abordagem ou só esculacha e vai embora?

P8 - Não, bate e me manda embora.

Pesquisadora - Não faz nada? Não leva para a Delegacia? Não faz o procedimento...

P8 - Nunca fui para a Delegacia.

Pesquisadora - Mas já foi enquadrado várias vezes?

P8 - Já.

Pesquisadora - E alguma vez...

P8 - Já roubaram dinheiro meu... Diversas vezes, né?

Pesquisadora - Eles pegam o dinheiro?

P8 - Levam dinheiro, além de bater, levam dinheiro.

Pesquisadora - E geralmente eles falam o quê?

P8 - Te xingam de tudo quanto é nomes. Te batem. Te agridem psicologicamente de todas as formas possíveis. Chegou uma vez, um policial ameaçou a fazer roleta-russa comigo. Sabe? Ele virou...

Pesquisadora - E por quê? Qual era a situação?

P8 - Por prazer sádico de maltratar um outro ser humano.

Pesquisadora - Ele te encontrou em que situação?

$P 8$ - Em uma favela. Eu nem tava com droga nesse dia. Só que logicamente que ele sabia que eu estava indo buscar a droga. Ele tomou meu dinheiro, me bateu; me ameaçou com o revólver. Colocou uma bala só no tambor revolver, ele girou e falou: "Agora a gente vai fazer uma brincadeira com você", né? Então... E outras vezes, muitas vezes.

Pesquisadora - E alguma vez, ou a Polícia ou algum agente do Estado te procurou para te oferecer tratamento?

P8 - Nunca.

Pesquisadora - Nunca ninguém te ofereceu tratamento?

P8 - Não.

Pesquisadora - E nunca a Polícia falou sobre tratamento?

P8 - Não.

Pesquisadora - É. Você já me disse que você nunca foi para a Delegacia, então por drogas também nunca passou pelo Fórum. 
P8 - Não. Por questão de droga, não. Eu passei pela Delegacia uma vez, por conta de uma agressão com a minha ex-esposa. Mas isso aí não deu nada. Porque chegou no Fórum, ela retirou a queixa tudo mais. Mas não por conta de droga.

Pesquisadora - E você alguma vez teve medo de procurar tratamento por temer uma represália, por ter medo de ser preso? Alguma coisa nesse sentido ou isso nunca passou pela sua cabeça?

P8 - Não. Nunca passou.

Pesquisadora - Mas você disse para mim que procurou uma clínica evangélica, que eu já sei, depois você me falou do PROAD. Você alguma vez procurou algum Posto de Saúde ou alguma instituição do Estado, por exemplo, um CAPS.

P8 - Sim. Procurei o CAPS.

Pesquisadora - E como foi o atendimento por lá?

P8 - Foi bom. Foi um tratamento que... Eu fiquei em tratamento no CAPS uns dois anos; um ano e meio, mais ou menos.

Pesquisadora - Em ambulatório?

P8 - É. Mas assim, no CAPS o problema era, se você falta, aí você tem que voltar a fazer novamente as triagens e tal. Até você voltar de novo com um médico e aí, às vezes, ficava sem medicação e tudo. Aí eu acabei abandonando.

Pesquisadora - Entendi. Se você não cumpre uma exigência você volta tudo para trás. E aí é cansativo?

P8 - É. É que nem aqui no PROAD. Já fazem mais de um mês que eu não consigo vir em grupo, não tava conseguindo vir em consultas. Mas aqui tem abertura de você ligar, pedir uma receita. Aí eu pedi para a minha mãe vir buscar a receita. Então não tive uma interrupção no tratamento.

Pesquisadora - E você acha que essas vezes que você foi abordado pela Polícia e a situação foi desagradável, alguma vez depois de um episódio desses, você pensou: 'poxa, tenho que procurar tratamento'? Isso te incentivou de algum jeito?

P8 - Incentiva..., pela forma desagradável que você..., pela forma desumana que você é tratado, né? Então, eu algumas vezes pensei em procurar tratamento pra não passar por isso de novo. Mas isso não foi o que me levou a tratamento.

Pesquisadora - Entendi.

P8 - Não foi por conta de violência por parte de policiais que me levou a tratamento nenhum.

Pesquisadora - Entendi. Está bom,(...). Muito obrigada. Acabou. 
P8 - Está bom. 


\section{ENTREVISTADO: P9}

Arquivo de Áudio:130807_003

Tempo: 00:14:07

Pesquisadora - Comecei a gravar, tá?

P9 - Ok.

Pesquisadora - Me fala seu nome completo.

P9 - (...)

Pesquisadora - Quantos anos você tem, [...]?

P9 - Quarenta e nove.

Pesquisadora - Você mora com quem?

P9 - Moro com minha esposa e com minha filha mais nova.

Pesquisadora - Quantos anos ela tem?

P9 - Dezoito.

Pesquisadora - Ah, já é uma moça. Está grandona. Você trabalha com o que?

P9 - Sou motorista de entrega de gás.

Pesquisadora - Está. Conta para mim um pouquinho como que começou a sua história com drogas. Desde quando você usa, o que você começou a usar. Se parou por um tempo, não parou. Conta a história.

P9 - Bem, eu comecei com 24 anos, depois que eu tive uma decepção em minha vida, através do futebol, né? Eu sempre quis ser jogador de futebol. Quando eu consegui, eu destruí em meia hora. Eu saí do time que eu jogava no Nordeste, consegui contrato para cá e, chegando aqui, em vez de eu me adaptar mesmo no clube que eu já estava pra assinar contrato, eu fui fazer uma brincadeira uma semana antes de assinar o contrato. E acabei perdendo minha carreira porque eu joguei.

Pesquisadora - Você torceu o joelho?

P9 - É. E como eu não tinha assinado o contrato, eles me dispensaram. Até então eu fiquei muito triste, muito abalado. Casamento já marcado. Então, eu comecei... Eu não bebia, não fumava. Comecei a beber. Aí com 24 anos eu conheci a droga, a cocaína. Maconha eu nunca fumei.

Pesquisadora - Mas primeiro você usava cocaína inalada. 
P9 - Isso. Só cocaína. Aí depois eu comecei a beber. Bebia só cerveja e usava cocaína. Consegui um serviço na gráfica do Banespa e depois de dois anos eu fiquei internado cinco meses.

Pesquisadora - Você foi voluntariamente ou involuntariamente?

P9 - Fui voluntariamente. Fiquei internado. Saí bem. Fiquei quase dois anos limpo.

Pesquisadora - Por que você decidiu se internar desta vez?

P9 - Porque minha esposa acabou pegando as drogas.

Pesquisadora - Ela começou a usar junto?

P9 - Não. Ela nunca usou.

Pesquisadora - Ah, ela pegou...

P9 - Ela soube que eu estava usando.

Pesquisadora - Ah, entendi.

P9 - E decidiu ir embora. Tudo. E eu fiz a promessa que ela não fosse embora, que eu ia parar. Até então só tinha uma filha. Duas filhas. Uma novinha de um ano e a outra já tinha três anos; e aí eu fiquei dois anos limpo e depois tive uma recaída forte e comecei a usar de novo a cocaína. Fiquei vários anos usando e fui fazer uma outra internação em 98.

Pesquisadora - E aí por quê?

P9 - Pelo mesmo motivo, né? Eu achava que não estava bem. Não estava legal. Desemprego daqui, sabe? Estava usando quase todos os dias.

Pesquisadora - Tá.

P9 - Aí fiquei internado numa fazendo mais 5 meses. Saí, fiquei 3 anos limpo. E aí comecei... Quando foi em 2003 a minha esposa resolveu me abandonar. Ela foi para a mãe dela, eu fui pra minha mãe. Aí comecei a ficar mais afundado nas drogas. Isso foi em 2003. Em 2004 eu tive outro emprego. Tava limpo também, mas separado dela. Só vendo meus filhos e a gente se falando e tudo, mas aí fiquei decepcionado também com isso. A gente discutia muito, né? E aí eu tive um AVC em 2005, janeiro de 2005, por motivo da cocaína. Não usava crack, nunca usei, nunca tinha usado. Aí, em 2004 eu saí da firma. Em 2005 eu tive o AVC e conheci aqui diretamente o PROAD. Fiquei 4 anos me tratando aqui. Tive duas internações. Aí 4 anos atrás eu parei de vir aqui.

Pesquisadora - Por que você parou?

P9 - Porque eu achava que não estava adiantando nada pra mim. Já tinha tentado suicídio e tudo. Esse tempo. Logo que eu entrei pra cá, pra fazer tratamento. E aí não ficou... A minha situação de lá também não estava nada bem. Meus filhos, principalmente essa de 18 anos 
tinha parado de estudar. Parou de estudar. Não estuda até hoje. Meu filho mais novo tem 16 anos hoje, também na época tinha entrado de não ir para a escola também, porque eu tava meio separado da minha esposa. E acabei indo para o Fórum com ele e ele está na madrinha dele, que é minha cunhada, tá cuidando dele. Hoje ele se encontra bem, mas minha filha ficou com a gente e ela não se encontra bem. Acabei tratando ela com drogas. Entendeu? E aí eu comecei a usar os crack. Faz uns 9 meses atrás eu comecei a usar os crack e vi que eu tava me afundando muito. Aí, há dois meses, eu no serviço, trabalhando de motorista, entregador de gás, carga perigosa, eu trabalhando, comecei a beber, fui, busquei droga, usei dentro do carro. Acabei esquecendo várias coisas, bujões, não sabia onde tinha entregado. Aí meu patrão pediu pra que eu fizesse um tratamento. Como eu trato desse AVC, dois meses atrás me alterou bastante. Aí eu caí na minha mãe por causa que eu tava drogado e começou a vir todos os problemas de novo. Aí eu fui pro médico. Tô aqui já há dois meses.

Pesquisadora - Mas ainda está em uso?

P9 - Sete dias limpo, sem drogas e só com a bebida. Só com... Bebida ainda foi três copos de cerveja no sábado agora passado.

Pesquisadora - Mas é um superavanço, hein?

P9 - Foi um avanço bom porque eu fiquei aqui bastante tempo sem usar drogas.

Pesquisadora - Que bom.

P9 - E, assim, tenho meus problemas familiares. Minha esposa teve um aneurisma esse ano. Me afundei mais ainda no crack porque só eu que tava cuidando dela. Tudo. Quase faleceu. Ficou internada. Ela tá em tratamento ainda. E, antes de dar esse aneurisma nela, eu tava me separando dela, em dezembro; aí eu fui obrigado, assim, não achei que era certo abandonar ela naquele instante. Aí fiquei com ela até hoje. Ainda estou cuidando dela ainda. E cuido da minha filha que há três meses ela está bem. Ainda não peguei drogas, não senti que ela chegou drogada. Tá mais caseira. Ela não parava em casa. Era só baladas, baladas.

Pesquisadora - Agora está mais tranquila.

P9 - Agora tá mais tranquila. Está me dando mais atenção.

Pesquisadora - Entendi. O que você achaque foi, assim, o principal motivo pelo qual você buscou tratamento? Foi a sua filha? Foi sua esposa? Foi por você? Foi essa situação do trabalho?

P9 - Então, agora foi por mim mesmo. Dessa vez foi por mim mesmo. Das outras vezes foi pra não perder as filhas, pra não perder a esposa. Mas eu senti que, desta vez, foi por mim mesmo. 


\section{Pesquisadora - Entendi.}

P9 - Porque eu estava numa situação muito desagradável. Já tava conhecido na Cracolândia, tava fora de casa.

Pesquisadora - Você ficou fora de casa um tempo?

P9 - Fiquei vários dias fora e tava muito triste pra mim.

Pesquisadora - Eles chegaram a ir te buscar?

P9 - Não. Não chegaram a me buscar porque é sempre assim. Pra eles, igual agora, esse tratamento meu, pra eles parece que eu não estou fazendo o tratamento. E eu tomo 9 medicamentos de manhã, 4 à tarde, depois do almoço e 8 de noite pra dormir. Quer dizer, para eles eu sinto que, meus filhos, principalmente, minha companheira, eles não dão aquela força, entendeu?

Pesquisadora - Entendi.

P9 - Fica muito difícil pra mim segurar. Esse tempo mesmo que ela ficou internada, fez essa cirurgia, eu segurei uma bronca que já tentei o suicídio, sabe? Usando muita medicação, muita coisa. Chegar a usar droga e subir uma passarela e... Por pouco. Então, eu, aqui agora, não sei explicar. Eu não tô me encontrando na vida. Não consigo me encontrar. Não consigo ver o meu outro lado dentro de mim. Sabe? Não sei o que eu quero da minha vida ainda.

Pesquisadora - Mas você sabe que não quer mais usar droga? Ou nem isso você tem certeza?

P9 - Então, eu tenho certeza que não quero mais usar droga, sabe? Mas, assim, no dia de amanhã, por exemplo, a gente tá numa fase de separação. Quer dizer, não sei na hora que eu me separar mesmo o que vai acontecer. Se ela passar mal e eu me revoltar com aquilo ou mesmo eu me revoltar. Eu não sei explicar isso, entendeu?

Pesquisadora - Você não consegue projetar lá na frente.

P9 - Não consigo me ver um futuro para mim ainda. Eu não tenho explicação pra isso.

Pesquisadora - Entendi. (...), você já teve alguma experiência com a polícia?

P9 - Nunca tive.

Pesquisadora - Nunca levou um enquadro?

P9 - Não.

Pesquisadora - Eles nunca chegaram perto de você?

P9 - Não.

Pesquisadora - E nos dias em que você ficou na rua, você chegou a ver a polícia por ali? Enquadrando alguém? 
P9 - Já vi já.

Pesquisadora - E como que foi isso? Como você viu? Eles são gentis? Não são gentis?

P9 - Teve várias vezes. Já vi várias vezes, inclusive, até, eu assim, na boca mesmo eles me deixarem de lado e irem para cima dos traficantes.

Pesquisadora - O usuário não interessa muito para eles.

P9 - Isso. Não interessa. Eu vi que eles não interessam muito. E vai embora. Sabe? "Vai embora daqui".

Pesquisadora - Eles mandam embora.

P9 - Eles mandam embora. Sabe? E os outros, falaram: "Vai lá para trás".

Pesquisadora - Entendi.

P9 - Aí no outro dia ficar sabendo que aquelas pessoas, uns foram presos, outros apanharam.

Pesquisadora - Mas só traficante?

P9 - Só aquele pessoal sem ser usuário.

Pesquisadora - Está. E, enfim, também durante esse tempo que você ficou na rua ou mesmo no tempo que você não estava na rua, alguém do governo que não fosse polícia, mas que fosse agente de saúde para chegar perto e te oferecer um tratamento. Alguém te procurou? P9 - Não.

Pesquisadora - Nunca te procurou também. Você já viu procurando alguém?

P9 - Não. Já vi. Já vi.

Pesquisadora - Já? E como acontece isso?

P9 - Eles abordam. Eles iam, assim, ficavam de longe mesmo. Alguns iam, eu não sei o que eles conversavam. Eu via só nesse sentido.

Pesquisadora - Está. Pelo fórum você também nunca passou por causa de droga? P9 - Não. Nunca passei.

Pesquisadora - Está. E alguma vez você teve medo de procurar tratamento porque você imaginou que você podia ser preso ou podia acontecer alguma coisa de ruim com você? P9 - Por ser preso nunca tive medo. Mas, assim, medo da rua, sabe? Tá usando e acontecer alguma coisa sempre tive medo sim.

Pesquisadora - Mas acontecer que tipo de coisa?

P9 - Briga, assalto, até morte mesmo. O pessoal vir...

Pesquisadora - Entendi.

P9 - Essas coisas assim. Esses ataques assim. Então, eu ficava muito com medo.

Pesquisadora - Tá. É só isso, (...). 
P9 - Só isso?

Pesquisadora - Só. Obrigadão. Vamos parar de gravar? 


\section{ENTREVISTADO: P10}

Arquivo de Áudio:130807_003

Tempo: 00:14:12

Pesquisadora - Vai gravar, tá?

P10 - Tá bom.

Pesquisadora - Fala para mim seu nome completo.

P10- (...)

Pesquisadora - quantos anos você tem?

P10- Quarenta e sete.

Pesquisadora - E o que você faz?

P10- No momento, tô desempregado.

Pesquisadora - Mas você trabalha com o quê?

P10- Trabalhava com pintura.

Pesquisadora - Pintura? Pintura de parede mesmo?

P10- Parede de casa.

Pesquisadora - Entendi. E você mora com quem?

P10- Eu moro com a minha mãe.

Pesquisadora - Mora com tua mãe. Você estudou até que série?

P10- Eu estudei até a primeira série, incompleto.

Pesquisadora - Do Ensino Médio?

P10- Isso.

Pesquisadora - Aquela depois da $8^{\text {a }}$ ?

P10- É.

Pesquisadora - Conta para mim um pouco da sua história com as drogas. Como foi? Quando você começou? Usando o quê? Procurou tratamento? Não procurou? Desistiu? Não desistiu? Toda uma historinha.

P10- Bom, eu comecei a fumar maconha.

Pesquisadora - Com quantos anos?

P10- Tinha uns 18 ou 19 ano.

Pesquisadora - E já fumava cigarro antes?

P10- Fumava. 
Pesquisadora - E álcool?

P10- Também bebia.

Pesquisadora - Tá. Então começou com álcool. Volta para trás. (risos)

P10- É. Então, eu... (risos)

Pesquisadora - Você começou a fumar cigarro com quantos ano?

P10- Eu tinha mais ou menos uns 11 ou 12 ano.

Pesquisadora - E beber? Também nessa idade ou mais velho?

P10 - Não. Mais velho.

Pesquisadora - Com quantos?

P10- Com uns 18 ou 19 ano.

Pesquisadora - Está. E aí com 18 também começou...

P10- Eu tomava vinho, não é? Mas eu exagerava um pouco às vezes. Eu ficava de fogo.

Pesquisadora - Tá. Aí começou a usar maconha?

P10- Comecei a usar maconha. Aí eu não sei o que deu ni mim, que eu deixei de fumar maconha. Aí eu conheci a cocaína.

Pesquisadora - Mas você ficou um tempo sem usar nada ou você já passou da maconha para a cocaína?

P10- Eu passei da maconha para a cocaína. E logo quando ela saiu, não é?

Pesquisadora - Quantos anos você tinha?

P10- Eu tinha uns 22. E depois eu comecei, terminei... Terminei não, eu deixei a cocaína e passei pro crack.

Pesquisadora - Entendi. Quantos anos você tinha quando passou para o crack?

P10- Tinha uns 28.

Pesquisadora - Vinte e oito anos.

P10- Isso.

Pesquisadora - E aí desde então você ficou só no crack ou você usa...

P10- Não. Eu parei com o crack.

Pesquisadora - Parou? Legal.

P10 - Parei. E também tem dois meses já que eu não uso cocaína.

Pesquisadora - Que legal. Você parou com o crack há quanto tempo?

P10 - Já faz tempo já. Já faz uns 2 ou 3 anos já.

Pesquisadora - Mas você usou durante quanto tempo?

P10- Usei durante uns 6 anos mais ou menos. 
Pesquisadora - Bastante. Por que você acha que passou do crack para a... Da cocaína para o crack?

P10 - Porque eu acho que não sei. No meu modo, a cocaína é melhor de usar. Não precisa de cachimbo, você não precisa de cinza.

Pesquisadora - Então, mas por que lá atrás você procurou o crack se a cocaína é melhor.

P10 - Não. Mas não tinha cocaína. Tinha cocaína, mas eu fiquei no crack.

Pesquisadora - Mas por quê?

P10- Não sei.

Pesquisadora - Se a cocaína é melhor. Está bom. Não sabe o porquê. Também a gente não precisa saber o porquê de tudo.

P10 - Então, eu passei a usar a cocaína e a cocaína é fácil de usar, você pode usar ela na rua, você pode usar ela no banheiro, você pode usar ela dentro de casa, no banheiro de casa, em cima da estante.

Pesquisadora - E crack dá mais trabalho?

P10- Dá mais trabalho.

Pesquisadora - Entendi.

P10 - Fora a fumaça e o cachimbo e as cinzas. Você fuma muito cigarro para fazer as cinzas e fuma o cigarro e fuma o crack. Dá vontade os dois, né?

Pesquisadora - Junto. E nesse tempo de uso de drogas, qual foi a primeira vez que você procurou tratamento?

P10- Foi quando eu tinha um problema no fígado, que eu fiz uns exames em São Paulo, fiz um checkup. No posto eu fiz. Com uma doutora. Ela me passou exame, pra mim fazer todos os exame, né? Completo. Fazer um checkup e aí acusou Hepatite C. Aí eles me encaminharam par ao Hospital São Paulo. Aí eu estava me tratando e eu fiz biópsia, tirei um pedaço do fígado. Eu tomei Ribaverina. Tomei Tejo. Depois de 6 meses me deram alta. E mais ou menos eu tô no Hospital São Paulo tem uns 12 a 13 anoS.

Pesquisadora - Ah, já está aqui no PROAD faz um tempão.

P10- Faz.

Pesquisadora - Entendi.

P10- Eu participo do grupo da Fernanda na sexta. Participei hoje porque tava cedo. A hora que você chegou não sabia quem era você.

Pesquisadora - É bom, não é? Aproveitar o tempo que está aqui.

P10- É. Mas não falei nada porque ela foi de uma assim, né? Começou assim. Tinha 15. 
Pesquisadora - Muita gente.

P10-É. Tá com o ibopebom, hein.

Pesquisadora - Diz para mim...

P10 - Já passei com a Débora.

Pesquisadora - Ah, a Débora foi o grupo que eu vim. Eu fiquei 4 meses com ele, não é?

P10- Já passei com a Cecília.

Pesquisadora - Já passou por muita gente.

P10- Com a Iane. Com a Bruna.

Pesquisadora - A Bruna vai fazer grupo comigo. Você já morou algum tempo na rua?

P10- Não.

Pesquisadora - Sempre ficou em casa?

P10- Sempre, mas eu passava a noite na rua.

Pesquisadora - Tá. E você já foi abordado pela polícia alguma vez?

P10- Já. Eu fui abordado pela Rota. Faz tempo já. Parece que foi 80, porque a gente tava indo pra Guarapiranga; que Guarapiranga, na época, tava secando. Porque moro perto de [ininteligível]. Chácara Santana, na Piraporinha. Em Burgeri. E a gente estava indo para Guarapiranga e tinha uma Rota parada assim na frente da gente, assim, com as portas aberta. Tinha 5 PM. E tinha um amigo meu que estava com maconha. Tinha um pouquinho de maconha assim. Não era muita. Era um baseado. Aí quando eu falei para ele: "Olha a Rota lá na frente". Ele falou: "Já dispensei”. Mas antes dele dispensar, o policial viu na hora; aí ele tava andando assim, ele jogou por baixo da minha mão.

Pesquisadora - E aí acharam que era sua.

P10- É. Acharam que era minha. Aí ele de lá veio. Mandou nós por a mão na cabeça. Perguntou de quem era a maconha. Aí mandou eu falar... meu amigo mandou eu falar que era minha. Eu falei que não era. Eu falei que não sabia de quem era. Aí eles falou: "Então entra aqui”. Pôs nós no camburão. Foi até no Guarapiranga, pegou mais dois. Encheu o chiqueirinho. Aí foi pra a 47 lá no Campo Limpo. Fiquei preso umas 2 horas mais ou menos.

Pesquisadora - Está. E depois soltaram?

P10 - Eu não assinei nada.

Pesquisadora - E mais recente? Nunca mais foi abordado?

P10- Já fui. Com baseado enrolado no bolso. Mas eu fui atropelado pelo um ônibus. O ônibus vinha, eu tava meio doido de cachaça, de... sei lá, maconha. Eu tomava Artemi, sabe aqueles comprimidos pra louco? Não sei se você sabe qual é; só vende na farmácia. Só vende 
com receita médica e azul, ainda. Então, eu misturei com álcool o remédio e fiquei meio doido. O ônibus vinha, né? Vinha mais ou menos como daqui no portão lá. Aí eu fui para cima dele. Aí ele veio, passou por cima de mim. Passou por cima do meu braço. O braço inchou, ficou assim. Passou perto da minha cabeça. Aí eu levantei debaixo do ônibus e sentei/ perto dele não tem ali um negócio grande que eles falam: “É proibido dar carona"? Aí eu sentei ali. Ele falou: "Cara, você é doido. Você quer morrer? Quer complicar minha vida. Aí foi levar eu no Piratininga. Os passageiros tudo dentro do ônibus. Depois ele voltou descendo todo mundo.

Pesquisadora - Não sei o que aconteceu.

P10 - Não sei se foi eles que avisaram que eu estava com droga. Aí chegou um fusca branco com dois policial dentro. Era civil. Aí eles me prenderam. Me deu tapa ainda, né? Aí levou eu pra 92.

Pesquisadora - Mas isso faz tempo também.

P10- Faz. Faz tempo. Acho que foi em 92.

Pesquisadora - É, porque Polícia Civil num Fusca branco. Faz tempo.

P10- Faz. Não, mas o fusca...

Pesquisadora - Era viatura descaracterizada.

P10- Placa fria.

Pesquisadora - Tá. Entendi. E pelo fórum, nunca? Ou já?

P10- Não. Não.

Pesquisadora - Tá. E você alguma dessas vezes que você foi levado para a delegacia, acho que a primeira, porque na segunda você foi atropelado, mas... por causa disso, você sentiu que devia procurar tratamento? Isso te incentivou a buscar?

P10- Motivou. Eu vim com minha tia aqui nos médicos. Então, eu sabia que tinha um grupo, que tinha a Rosa que adiantava tudo, cuidava para a gente vir para o grupo, não é? E eu comecei a participar lá em cima. Depois... lá naquela rua lá da Varpa, aonde faz coleta de sangue. Era lá. Depois mudou para cá, numa rua que tem... uma rua vindo, você entra à direita. Era numa casinha lá. Depois mudou para cá.

Pesquisadora - Você conhece todos os endereços? Você já se sentiu diferente das outras pessoas por usar drogas?

P10- Já.

Pesquisadora - Por quê?

P10- Porque fica estranho. Fica meio apagado. 
Pesquisadora - Mas as pessoas te olham diferente?

P10- Olha.

Pesquisadora - Olha de que jeito?

P10- Olha com olhar que está vendo que você está doido. Está louco, não é?

Pesquisadora - Têm medo?

P10- Tem. Seu olho cresce.

Pesquisadora - E você acha que as pessoas entendem que é uma doença ou acham que é falta de vontade?

P10- Eu acho que é falta de vontade de se tratar. Aí...

Pesquisadora - Você acha que as pessoas têm preconceito?

P10 - Têm. Têm. Eu fui casado 4 anos e minha mulher pegou usando cocaína dentro do banheiro. E ela foi embora.

Pesquisadora - Você ficou triste.

P10- É. fiquei. Aí me joguei, não é?

Pesquisadora - Aí piorou?

P10- Aí o crack, aí bebida, cheguei até a pegar carrinho de ferro velho para catar ferro velho para vender. Para usar droga.

Pesquisadora - Entendi. E alguma vez...

P10- Já vendi roupa minha. Já peguei coisa da minha mãe para vender. Então, tem que dar um basta nisso, não é?

Pesquisadora - Entendi. Você já não aguenta mais.

P10- Não. Porque a droga destrói a gente. Não durmo, não como, só líquido que desce. Então...

Pesquisadora - Alguma vez alguém do governo veio te oferecer tratamento? Te procurou?

Te ofereceu tratamento? Te falou para se tratar?

P10- Não. Só vi que minha mãe falou que tinha umas clínicas lá para o lado do Jardim São Pedro, mas aí ela foi lá e viu. Era mal organizado. Era bagunçado, não é?

Pesquisadora - Entendi.

P10- Lá trabalhava. Aí ela decidiu não investir nessa clínica. Mas eu não fui internado.

Pesquisadora - Entendi. E você não tem vontade?

P10- De ser internado? Não.

Pesquisadora - Está.

P10- Eu acho que não sou tão viciado assim para outro dia ir para a clínica. 
Pesquisadora - Está. Entendi.

P10 - Tem muitos aí que vai para a clínica, sai da clínica, começa a usar droga de novo. Eu acho que é o remédio e a maioria da parte é você ter força de vontade.

Pesquisadora - Então, você acha que para alguém parar de usar droga o que precisa é isso: remédio e força de vontade?

P10- Isso.

Pesquisadora - E mais alguma coisa?

P10- E tratamento. Tratamento. Psiquiatra, psicólogo.

Pesquisadora - É importante ter ajuda?

P10- É importante, porque sozinho a gente não consegue. Tem que ter alguém. Minha mãe participa do grupo de segunda-feira. Com a Thaís.

Pesquisadora - Então está bom. É isso.

P10- É só isso?

Pesquisadora - Só isso. Muito obrigada.

P10- Obrigada a você. 


\section{ENTREVISTADO: P11}

Arquivo de Áudio:130807_003

Tempo: 00:30:51

Pesquisadora - Comecei, tá? Fala para mim seu nome completo.

$\mathbf{P 1 1}-(\ldots)$

Pesquisadora - Que grande.

P11-É. Meu pai colocou esse nome.

Pesquisadora - Quantos anos você tem?

P11- Vinte e cinco.

Pesquisadora - E você mora com quem?

P11- No momento estou morando com minha madrinha e meu padrinho.

Pesquisadora - Tá. Você estudou?

P11- Estudei até o segundo colegial.

Pesquisadora - Conta para mim um pouquinho como foi sua história com drogas. Como começou? Com que droga começou? Com que idade?

P11- Ah, eu sou dependente química desde os 13. Comecei fumando maconha com 13 para 14. Depois eu comecei a cheirar cocaína com 15. Depois eu conheci o crack com 17 e as outras drogas, LSD, balas essas coisas, com 18.

Pesquisadora - Tá. E por que você acha que começou?

P11- Ah, eu comecei por curiosidade e também porque a minha me prendia muito. Minha mãe era alcoólatra. Minha mãe bebia todo dia e aí depois eu comecei a falar: Pô, ela bebe eu também vou beber. Aí comecei já bebendo. Bebendo, fumando maconha na escola, matando aula e não me dava muito bem com ela.

Pesquisadora - Vocês moravam só as duas?

P11- Nós morávamos só nós duas. E aí foi indo, foi indo, quando eu tinha 18 anos eu conheci um cara que era ex-presidiário. É presidiário, porque ainda está preso de novo, e ele me apresentou o crack, porque até então eu só cheirava de vez em quando, fumava maconha. Eu comecei a fumar pedra com 18 anos e aí eu desandei.

Pesquisadora - Você acha, então, que até o crack você tinha um certo controle?

P11- Então, eu comecei a fumar só no sisclado, que é o cigarro com a pedra. Aí depois de um tempo não estava dando mais nada, eu comecei já a fumar no cachimbo. 
Pesquisadora - Aí que foi o pior.

P11- Aí eu fiquei meio desnorteada. Fui internada... Eu mesmo me internava porque minha mãe não me internava. Eu mesma me internava. E aí eu comecei a usar droga com 18, crack; eu nem sei onde eu estava. Me perdi.

Pesquisadora - Não. Você mesma se internava porque sua mãe não te internava.

P11- Eu mesma me internava porque eu comecei a ficar paranóica. Aí eu me internei três vezes em Psiquiatria. Aí eu saí mais doida ainda. Porque a Psiquiatria que eu ficava era contenção, era uma loucura.

Pesquisadora - Como era loucura?

P11- Contenção é qualquer coisinha que acontece é amarrada. E toma injeção na perna. Toma injeção na perna.

Pesquisadora - Você ficou quanto tempo?

P11- Ficava 15 dias. A desintoxicação. Era em São Bernardo do Campo. Chamava Lacan. Só que a parte das mulheres dependente química e quem tinha problema de cabeça era tudo junto. E dos homens era separado. Então, a gente tinha que zelar uma força muito grande para não bater nelas, porque elas batiam na gente, mas a gente era lúcida. Então, a gente não podia bater nelas, porque senão quem era amarrado era a gente. Não elas. Contidas. Amarrada numa cama, amarrava perna braço. E aí eu saí, mas eu ficava só para desintoxicar, eu saía, caía em tentação, eu voltava a usar drogas.

Pesquisadora - Tá. E porque você procurava o tratamento? Qual era o motivo? O que te fazia procurar?

P11- Olha, na verdade, hoje eu penso que eu procurava o tratamento para me engordar. Eu mesma mentia para mim mesma falando: “Ah, vou ficar lá 15 dias de boa, vou sair bonita". Porque eu entrava um trapo e saía gorda, bonita. Mas isso depois de um tempo eu fui vendo que eu mesma estava me enganando, não é? Eu mesma estava me enganando porque o tratamento é aqui fora. Não é dentro de clínica. O tratamento é aqui fora.

Pesquisadora - Por que você acha isso?

P11- Depende de cada caso, porque a pessoa vai ficar lá, vai comer, vai dormir, vai ficar boa. Lógico, lá não tem droga. Aí na hora que ela sai, vai vir milhões oferecer para ela porque vai ver que ela está bem.

Pesquisadora - Você acha que quando você está bem, as pessoas vêm te oferecer?

P11- Vem. Oferece.

Pesquisadora - Por que será? 
P11- Não sei. Acho que: “Ah, só um tirinho. Só um peguinha. Não vai dar nada”. Aí que começa tudo. Você não pode dar um primeiro pega nem o primeiro tiro.

Pesquisadora - Mas a pessoa não sabe disso? O outro usuário não sabe que se você der um tirinho vai voltar tudo?

P11- Então, eu conheço gente que cheira até hoje e consegue se controlar. Eu já sou diferente. Se eu cheirar, eu já vou querer beber e eu bebo destilado para caramba. Se eu fumar pedra, vou querer beber. Então, é o efeito escadinha. Depois eu vou beber, depois vou usar química, depois vou querer fumar maconha para amenizar tudo e passar a brisa em todas e aí eu faço um coquetel completo. Eu sou assim. Agora, conheço gente que não é. Que consegue se controlar. Eu, no meu caso, eu perdi o controle. Eu sou muito impulsiva. Sou muito ansiosa. Então, qualquer coisa que me derem, eu quero demais. Então, se me derem cogumelo demais, eu vou querer cogumelo demais. Se me derem bala demais, vou querer outra bala demais. Eu sou impulsiva. Então é por isso que eu estou aqui trabalhando isso também. Minha ansiedade, porque sou muito ansiosa. Também eu não me dava bem com a minha mãe, então, qualquer briguinha, eu saía e usava, saía e bebia, saía e fumava maconha. Eu era assim. Agora não. Agora estou trabalhando isso. Depois que minha mãe faleceu, com 22 anos, aí eu piorei, porque minha mãe faleceu de cirrose em casa. Minha mãe morreu em casa, na minha frente. E aí eu piorei. Aí eu desandei mesmo. Aí entreguei no crack total. Aí, nesse tempo eu me internei de novo.

Pesquisadora - Aí desta vez por quê?

P11- Porque desta vez eu estava três vezes pior do que eu já era. Eu estava, assim, vendendo tudo da minha casa. Estava vendendo minhas panelas, estava vendendo minhas roupas, só não estava me vendendo, porque de resto estava vendendo tudo. Aí na época, eu vou fazer artesanato, eu parei de fazer artesanato, parei com tudo, vendi tudo que era meu, depois o Sandro, nessa época em que minha mãe faleceu, o Sandro saiu da cadeia. Aí ele já era usuário de crack. Muitas vezes ele foi preso por causa que ele ia roubar para fumar pedra. Aí era pego e ia preso. E aí ele saiu da cadeia, a gente começou a viver junto. Aí estava tudo bem. Estava morando em Mauá, estava tudo bem. Aí ele recaiu. Daí, nessa que ele recaiu, quando ele recaía, ele começava a roubar. Ele se transformava. Ele era um anjo, mas se fumava pedra, ele roubava até o papa. Aí ele foi preso de novo. Aí nessa que ele foi preso, eu inventei de colega minha para morar comigo e essa colega minha começou... Falava tanto de mim, que eu fumava pedra, aí ela começou a fumar pedra dentro da minha casa sem eu saber. Aí eu tive que entregar a casa. Aí nessa que eu entreguei a casa, eu fui morar na rua. Fui morar 
na rua. Vendi tudo que era meu e fui morar no Rodoanel, em Mauá, na casa de uns bandidos lá, que todo mundo fumava pedra também. E aí nessa época era muita coisa roubada dentro daquela casa e eu morava dentro daquela casa e usava droga todo dia. Eu fiquei um "zumbi". Eu virei um “zumbi” porque eu não dormia. Porque primeiro não dormia porque falava: "Os homens vai invadir aqui, eu vou...”. Fora que, antes da minha mãe falecer, a gente foi presa. Nós duas. Nós duas fomos presas por causa de um policial que armou para a minha mãe, coisa de rixa antiga que ela tinha com Justiça, porque ela era advogada e ele armou um flagrante lá de extorsão, a gente foi presa.

Pesquisadora - Flagrante de extorsão com quem?

P11- Com a minha mãe.

Pesquisadora - Tá. E aí você foi junto com ela?

P11- Eu fui junto porque eu estava junto com ela.

Pesquisadora - Entendi. Você ficou presa quanto tempo?

P11- Acho que fiquei uns quatro meses só, porque a minha tia me ajudou a tirar nós três, porque minha tia... Outra prima da minha mãe que estava junto na hora errada e dançou. Quem prendeu a gente foi o Garra. E aí, o que acontece? A gente saiu, depois que a gente saiu, minha mãe faleceu. Aí eu fiquei com aquele negócio de ódio, de vingança, eu queria matar aquele policial. Eu fui nas biqueiras, eu falei com todos os bandidos, vou pegar uma arma, vou querer matar aquele polícia e aí eu fiquei paranóica porque minha mãe morreu e foi uma injustiça que aconteceu com ela, porque na verdade, foi ele que bateu nela. Ele empurrou ela e depois armou como se tudo ele fosse a vítima. E armou o Garra para prender a gente em São Bernardo do Campo. Aí depois que a gente saiu da cadeia, que minha mãe faleceu, aí fiquei mais louca ainda. Queria matar esse policial. Eu cercava a delegacia. Eu seguia ele. Ele não me via, mas eu seguia ele. Eu queria matar ele de qualquer jeito. Foi aí quando o Sandro saiu, que era meu ex-marido, trabalhou bem minha cabeça. Falou: “(...) não mexe com essa raça, que você vai morrer. Não sei o que. Não sei o que. Não mexe na bosta. Quanto mais mexe na bosta, mais ela fede". Aí ele trabalhou, trabalhou minha cabeça. A gente foi morar junto. Aí foi nessa que a gente foi morar junto, estava tudo lindo, perfeito, foi quando ele recaiu. Aí ele recaiu e ele começou a roubar. Ele foi preso de novo. E eu, como já quando eu tinha 18 anos eu visitava ele e tudo, tal, ele me levava junto, essas coisas, eu já estava de saco cheio dessa vida, eu falei: “É a última vez”. Aí ele foi preso. Acabou. Nunca mais eu vi ele. Ele acha que eu estou morta. Ele está preso ainda. Ele acha que eu morri. 
Aí eu tive que entregar a casa, morei com essa minha colega. Essa minha colega começou a usar droga lá dentro da minha casa. Eu estudava e trabalhava. E aí um dia eu peguei ela, expulsei todo mundo. O dono pediu a casa, aí eu fiquei mais puta ainda porque eu vendi tudo que era da minha casa e caí no mundo. Aí conheci esses malucos aí. Esses bandidos aí. Eles falaram: "Pode morar aqui”. Eu fui morar na casa lá no Rodoanel, numa casinha de madeira no meio do mato. Se entrar na casinha, só tinha Harley Davidson no lugar. E droga. E eu cuidava daquele lugar. Mas eu não dormia porque eu fumava pedra e pronto. Os homens vai invadir aqui, eu vou morrer, vou ser presa e eu não queria mais voltar para a cadeia não. O lugar é horrível. E aí depois desse tempo eu conheci um cara chamado Romildo, que me tirou de lá, me levou para a casa dele e a gente casou. Só que aí, de bonzinho que ele era, ele se transformou num lobo. Tentou me matar três vezes. Me jogou da laje. Eu abri a cabeça. Levei um soco. Olha, isso aqui é um soco. Enfiou um prego aqui em mim. E eu sempre voltando. Vai e volta, vai e volta com ele, uma hora teve um dia que eu não estava fazendo nada, ele chegou em casa me batendo, jogando o armário em cima de mim porque ele também usava droga. A gente começou... Aí eu recai de vez com uma pedra com ele, porque ele também usava pedra. E aí um belo dia ele chegou em casa bêbado, jogou o armário em cima de mim, jogou tudo, eu só catei meus documentos e fui embora. Nunca mais voltei.

\section{Pesquisadora - (...)}

P11- Oi. Bom, aí eu fui embora. Nunca mais voltei. Aí eu pedi ajuda para a minha madrinha. Com a minha madrinha para mim morar com ela. E aí ela me deu uma assistência toda, para mim morar com ela. E eu faço arte de rua. Eu sou hippie, então eu fico na Paulista, fico na São João, conheço a Cracolândia de cor e salteado. Piranga, todo o centro. Eu conheço todinho. Então, há esses tempos atrás eu tive uma recaída feia. Eu tenho mania de ir para a casa da minha madrinha e não voltar porque eu acho que eu sou assim. Eu não volto. Uma hora eu estou aqui, uma hora estou em Vampinhos, uma hora eu estou em Sorocaba, uma hora estou em Suzano. Na época em que você estava me procurando, eu estava em Suzano. E usando droga pra caramba; porque a gente vende pra caramba, mas tem uns que usa droga pra caramba. Então, o dinheiro é no crack. No "tonho". Que a gente fala o "tonho". Aí eu pedi ajuda para ela e ela me deu uma chance. Eu comecei a fazer artesanato. Mas antes disso, antes de eu pedir ajuda para ela, eu estava morando na rua, eu estava acampando lá na São João. Depois eu tinha barraca. Depois acampava na São Bernardo. Eu ia acampando para tudo que é lugar. Campinas. Vai para lá, vem para cá, vai para lá, volta para cá, aí eu fiquei 
doente. Eu fiquei doente do meu fígado, mas isso já antes eu estava, não é? Eu venho aqui no PROAD desde os 18 anos. Entre idas e vindas. Nem era aqui. Era na outra casa ainda. Uma casinha verde lá em cima. E aí o que acontece? Eu estou com meu fígado inchado. Aí eu comecei a me sentir mal, vomitar, ter diarréia, e aí eu voltei para a casa da minha madrinha. Pedi ajuda para ela de novo. Nessa de pedir ajuda para ela de novo, um belo dia eu fui lá para Santo André, esses tempos atrás, e recaí feio de novo no crack lá. Fiquei uns 15 dias. Voltei semana retrasada pedindo uma internação aqui no PROAD para mim. Nem voltei para buscar meu pano, meus artesanatos ficou tudo na paulista. Minha amiga está tomando conta lá das minhas coisas. Eu expliquei para ela. Ela falou: "Não, fica de boa. Vai lá, se trata". Porque sou muito impulsiva. Não sou assim, tipo equilibrada. Tem uns maluco que é equilibrado. Eu não. Eu começo, eu desando, entendeu? E ela falou: "Fica lá de boa porque senão...”. Se eu recaio na pedra, eu não consigo fazer nem um brinco. Eu falei: “Ah, então deixa eu ficar de boa, deixa eu ficar sossegada senão eu não consigo fazer nada". Tenho que fumar maconha todo dia para mim não ter vontade de usar química. E aí eu retornei ao tratamento aqui. Maconha me segura. Eu tenho que fumar maconha todo dia. Eu só não estou esses dias sem fumar porque estou tomando remédio e não estou indo na Paulista, porque na Paulista... Lá tem maconha todo dia. No Teatro do Masp ali.

Pesquisadora - Você acha que você tem que fugir das situações que têm drogas, porque senão você não consegue se controlar. Você não está fumando maconha, mas se você for para a Paulista...

P11- Se eu for para a Paulista, eu fumo maconha. Tenho certeza.

Pesquisadora - Você não consegue controlar? Não consegue falar: "Não".

P11- Então, para a maconha não.

Pesquisadora - Mas para o crack...

P11- Para o crack eu consigo. Se eu não fumar a primeira. Se eu der o primeiro trago aí eu já não consigo mais falar não. Aí eu já quero outro trago. Outro trago.

Pesquisadora - E porque agora você, de novo, decidiu se tratar? O que você quer? Quais são os motivos?

P11- Ah, eu decidi me tratar porque eu não quero ter o mesmo destino da minha mãe, sabe? Ela morreu em depressão por causa do fato que aconteceu com ela desse policial, por causa do meu padrasto. Ela morreu em depressão. Ela morreu de cirrose hepática. E toda a minha família... Meu pai. Eu não converso com meu pai. Eu só converso com irmão. Todos bem. Todo mundo na família bebe. E minha mãe bebeu a gravidez inteira. Não sei se isso é 
hereditário. Mas eu tomo pinga que nem água. Aqueles corotinho. Viro. Eu viro. Não tomo de golinho. Eu viro. Então, eu falei: "Não quero ter o mesmo destino da minha mãe". E aí depois que eu fiquei sabendo que meu fígado estava meio "zoado", eu resolvi me tratar direito, porque é a primeira vez no PROAD em seis anos que eu estou vindo duas semanas direto, porque isso eu nunca fiz na minha vida. Eu vinha uma vez por mês e olhe lá.

Pesquisadora - Passa ainda pela sua cabeça interromper o tratamento?

P11- Não. Agora não. Agora não.

Pesquisadora - Uma pergunta mais de sentimento, assim. Você já se sentiu diferente das outras pessoas por ser usuária de drogas? Você acha que já te olharam diferente?

P11- Com certeza.

Pesquisadora - E por quê? Você acha que as pessoas te olham como?

P11- Quando você está usando crack? Droga? As pessoas olham como se fosse: "Olha lá. Sem futuro. Vai morrer. É nóia”. Porque é isso que acontece. Por exemplo, a gente mexe com artesanato, os hippies não se mistura com quem é favozeiro, aquele que só bebe e pede dinheiro para usar a droga dele e a cachaça. Isso para a gente é favozeiro. A gente não. A gente usa droga, mas estamos fazendo ali a nossa arte, estamos vendendo coisas que a gente mesmo faz. Então, se um cara desse cola do nosso lado, ninguém vai vir no nosso pano. Ninguém vai vir. Vai falar: “É igual”. Entendeu? Ninguém vai vir. Que nem na Cracolândia, eu vou lá, às vezes eu passava lá, pegava droga e ia embora. Fumava na São João. Porque se você ficar lá, você é igual. É complicado. As pessoas olham você... Se você ficar junto, eles olham você: "Pronto. É um nóia". Eu mesma já tive esse pensamento quando parei de usar um tempo, quando eu fiquei um tempo suava, eu passava falava: "Nossa, eu estava assim. Meu Deus eu estava desse jeito. Não acredito". Você fica um zumbi. Entendeu? Mas você não pode fumar a primeira. Se você fumar a primeira, aí você ... Todo mundo é amigo, é tudo igual, porque você está naquela brisa daquela paranóia da droga. Você não está nem vendo. Você se esquece que está todo mundo te vendo, entendeu? Você esquece do mundo. Você só quer aquilo.

Pesquisadora - Fora essa experiência que você teve com a polícia, por causa da sua mãe. Você já teve alguma outra experiência com a polícia por causa da droga? Já tomou enquadro? P11- Ah vários. Vários. Várias vezes já me enquadraram, já pegaram a minha droga. A Guarda Civil Metropolitana. São Caetano. Várias vezes já pegou minha droga. Uns jogam fora, outros cheiram na minha frente. Por exemplo, cocaína. Já me pegaram várias vezes 
com cocaína, guarda civil. Colocavam no carro mesmo e falavam: “Olha, (...). Que legal”. Cheiravam na minha frente. Outros jogavam fora.

Pesquisadora - Mas não costumam levar para a delegacia?

P11- Nunca me levaram para a delegacia porque eu sempre falei a verdade: "Você é usuária?” Sou. “O que você usa?” Tudo. “O que você tem aí?” Está aqui. Está aqui. Quer levar? Leva. Porque para conseguir droga é fácil. Pode levar. Daqui a meia hora eu tenho de novo.

Pesquisadora - Então, eles nem se interessam pelo usuário? O usuário eles não levam para a delegacia?

P11- Usuário eles não levam. Eu, pelo menos, nunca fui para a delegacia por estar fumando, nada.

Pesquisadora - Mas já te pararam algumas vezes na rua?

P11- Já. Rota já me parou. A Rota é um pouquinho mais... Já me pegou com uns pinos, aí jogaram fora.

Pesquisadora - A Rota é um pouco mais o que?

P11- Um pouco mais...

Pesquisadora - Truculenta?

P11-É. Eles cheiram, todos os caras da Rota. Eles chegam com a arma na sua cabeça, sabe? Você fica meio em choque.

Pesquisadora - Você já passou por alguma situação assim mais violenta com a polícia?

P11- A polícia? Olha, eu acho que não. Eu só passei uma vez que eu estava lá na Heliópolis e eu entrei para pegar dez cocaína, dez pinos e no carro ficou meu primo e meu amigo. E quando eu saí, eu entrei no carro. Aí foi uma coisa muito, assim, Deus. Foi Deus ali. Eu entrei no carro e, na hora que eles iam ligar o carro, eu falei: "Não. Eu quero ir no banheiro". E tinha um caminhão em frente ao carro. Aí eu saí do carro e fui embaixo do caminhão fazer xixi. E os dois estavam no carro. Nessa, que eu saí do caminhão e fui embaixo do caminhão, estava com os 10 pinos no sutiã. Fui embaixo do caminhão. Estou lá fazendo xixi, a Rota parou atrás do carro dos meus primos. Quando olhei por debaixo do caminhão que era a Rota, eu escondi os 10 pinos na roda do caminhão e saí. E aí a gente falou a verdade, mas uma versão: “O que vocês estão fazendo aqui?” Ah, a gente veio pegar... Era mentira, mas a gente veio pegar um amigo nosso, que era meu primo. E o que ela está fazendo ali? "Eu fui fazer xixi”. E eu tinha acabado de sair do caminhão e fui em direção a eles. Aí os caras da Rota foram até o caminhão, olhou, olhou e olhou e não achou os 10 pinos. Porque na época 
eu era até menor de idade e os dois eram maiores. Eles iam assinar uma indução de menor, eu ia me foder, entendeu? Todo mundo ia se foder. E aí o que aconteceu? Aí, eles foram o caminhão. Olharam, olharam, olharam, não acharam nada. E enquanto isso, o outro dando psicológico na gente, tentando saber por que nós estávamos ali. Por quê? Por quê? Por quê? E aí sai um cara... Eu lembro que saiu um neguinho lá do nada, ligou o caminhão e foi embora. Ele levou o caminhão e foi embora. Ligou o caminhão e foi embora com os 10 pinos na roda. Aí eu fiquei branca, assim, quando fui ver o caminhão indo embora. Não acredito. Aí terminou de levar enquadro: "Pode ir embora. Se a gente encontrar vocês aqui, vocês vão tudo preso. Vocês vão para a cadeia. Vocês vão presos. A gente vai forjar vocês e vocês vão todos presos".

Pesquisadora - O que é forjar vocês?

P11- Colocar drogas na nossa bolsa e falar: "Pronto. É seu." Entendeu?

Pesquisadora - Você já viu?

P11- Já. Já vi muita gente forjada. Já. Na cadeia, mesmo, feminina vi duas que foram forjadas. Jogaram a droga no quintal delas. Era uma senhora de 65 anos. Foi presa por tráfico, porque jogaram a droga no quintal dela. E aí a polícia foi achar que os cachorros estava no quintal dela, você mesmo vai. Acabou. E aí, o que acontece? Depois que a Rota foi embora meus primos perguntaram: “[...] cadê os pinos?” Vocês não vão acreditar, cara. Eu coloquei os pinos na roda do caminhão. O cara ligou o caminhão e foi embora. Até hoje não acredito nisso. Até hoje. Até hoje deve estar lá.

Pesquisadora - Foi melhor do que terem pegado.

P11- Foi melhor do que terem pegado, porque senão eles iam se ferrar. E eu também.

Pesquisadora - E já foi pro Fórumalguma vez por causa de droga?

P11- Não. Para o Fórum não. Por causa de droga não.

Pesquisadora - Você acha que alguma vez o medo da polícia, o medo de ter enquadro te fez repensar o uso? Ou não foi?

P11- Já. Já. Tanto é que quando eu saio da biqueira, eu já fico naquela segunda.

Pesquisadora - Mas você tem medo de ser presa por tráfico ou pelo uso? Ou de cumprir aquelas medidas alternativas?

P11- Eu tenho medo de ser presa por tráfico, porque é inafiançável, não é?

Pesquisadora - Mas cumprir as medidas do uso...

P11- Como assim? 
Pesquisadora - Porque portar droga para uso pessoal é crime também. Só que eles deveriam te levar para a delegacia, fazer um termo circunstanciado e aí eles podem aplicar três tipos de medida que é comparecimento obrigatório a cursos sobre os efeitos das drogas, prestação de serviços à comunidade ou pagamento de multa.

P11- Mas se tiver com 3 pinos e eles me pegarem eu posso...

Pesquisadora - Pode. São essas três medidas. Não é cadeia. Não tem pena de prisão. Mas você pode ser condenada a prestar serviço à comunidade. Você não sabia?

P11- Não sabia. Não sabia.

Pesquisadora - Mas o porte para uso também é crime. Então, se você não sabia não dá para ter tido medo, não é?

P11- Nossa. Agora vou ficar com medo.

Pesquisadora - Qualquer quantidade de droga.

P11- Até um baseado? Uma paranga? Até uma paranga?

Pesquisadora - Por isso que eu te perguntei se eles te enquadravam e te levavam para a delegacia. Você disse que eles jogam fora, mas não é. Na verdade, eles estão prevaricando, porque a obrigação deles seria te levar para a delegacia.

P11- Mas essa lei entrou quando?

Pesquisadora - Em 2006.

P11- Nossa. Não sabia. Não sabia, gente.

Pesquisadora - A lei anterior era pena de prisão para usuário. E aí, a lei, desde 2006. São essas medidas alternativas que, na maioria das vezes, é uma prestação de serviços à comunidade ou comparecimento a cursos sobre os efeitos das drogas.

P11- Ah, não sabia disso. Eu achei que, tipo assim, pegar com 6 entorpecentes já era tráfico. Pesquisadora - O tráfico não é só quantidade. São outros fatores também. Onde você está. Se é ponto de tráfico, se não né. Se você tem histórico, se não tem. O tanto de dinheiro que você tem na bolsa. Se o dinheiro está picado. Se a droga está em porções pequenas ou está numa porção maior. Então, tudo isso é considerado para o tráfico. Você pode estar com 10 quilos de cocaína e ser usuária. Você ia usar aqueles pinos, não ia? Ou você ia vender?

P11- Eu ia usar.

Pesquisadora - Então pronto. Mas depende de ter um advogado. É provável que você fique presa para depois conseguir te soltar. O tráfico é muito mais severo, mas ter um baseado, ter uma ponta já é crime. 
P11- Nossa. Eu não sabia. Caraca. Nossa. Eu não sabia. Vou falar para todo mundo isso daí agora.

Pesquisadora - Mas se você quiser procurar, eu te dou o número da lei e o artigo.

P11- Ah eu vou procurar. Vou.

Pesquisadora - Mas, então, se você tivesse que falar...

P11- Vou falar: Minha advogada... Como é seu nome?

Pesquisadora - Gabriela.

P11- Gabriela falou isso. Ela é chiquérrima. Vocês vão ver.

Pesquisadora - Obrigada. Mas você acha que procurar o tratamento foi mais pelos problemas de saúde, por não quer terminar como sua mãe do que por medo da polícia, por exemplo?

P11- É. Meio da polícia, porque quem entrou na cadeia não tem mais medo de cadeia. Cadeia não é perpétua. Quem entra lá... Antes eu morria de medo de ser presa. Nossa. Fui presa. Nossa. É horrível. Lógico. Você fica louca lá dentro. Eu fumava maconha todo dia na cadeia. Você fica louca lá dentro. Lá tinha cocaína na cadeia. Tinha cachaça na cadeia. A gente pagava propina para o carcereiro. Ele entrava Vodka, Whisky, tudo. Então, hoje em dia, por exemplo, as leis no papel é tudo lindo, mas em prática é outra coisa. O dinheiro conta tudo. Tudo é dinheiro. A gente pagava para o carcereiro. As irmãs lá pagavam, a gente fazia festa na cadeia. Na nossa cela tinha até DVD. Televisão, DVD, CD, tudo. Só não tinha quando o Garra entrava. Quebrava tudo, quando tinha blitz. Mas eu usava e aí eu consegui ter um poder maior lá dentro da cadeia porque lá dentro é assim. Não é não. Lá não tem tratamento. Entendeu? Não é não. Você usou? Você fez dívida? Você tem que pagar. Não adianta... Ou então nem usa. Entendeu? O que as irmãs faziam? Elas davam farinha para todo mundo de graça para depois as meninas ficarem doidas querendo mais. E aí, mais. E um pino lá dentro é $\mathrm{R} \$ 30$.

Pesquisadora - É supervalorizado?

P11- É R\$ 30,00. Uma maconha é R\$ 15,00. Só não tem crack. Graças a Deus. Se tivesse crack, já acabava com a cadeia inteira. Aí elas faziam isso. Para instigar. Aí quando não tinha mais dinheiro, ligava para a mãe: "Ah, mãe, pelo amor de Deus, deposita em tal conta tanto”. Para instigar, porque ela nem usava. Ou senão, eu cheguei a usar uma vez lá porque minha mãe ficou na cela das irmãs. Minha mãe era doida. Aí a minha mãe, foi que em consideração à minha mãe, porque minha mãe era advogada, elas deixaram eu não pagar, mas eu fiquei na fissura. Eu dei um tiro, fiquei querendo mais: "Quero mais. Quero mais. 
Quero mais”. Mas aí eu tive que aguentar. Não pedi. Porque lá não tem como. É a mesma coisa na rua. Então, eu vejo por aqui na rua. Aqui vinha um monte de gente oferecer. Se eu não tiver uma força de vontade mesmo, um poder de pensamento mesmo, matar um leão por dia, eu recaio. Entendeu? Era difícil. É difícil. Não é fácil. Mas eu estou caminhando aí.

Pesquisadora - E vai dar tudo certo. 


\section{Apêndice 4 - Transcrição das Entrevistas com Profissionais da EQUIPE FIXA}

\section{ENTREVISTADO: E1}

Arquivo de Áudio:130807_003

Tempo: 00:10:16

Pesquisadora - Primeiro preciso que você me fale seu nome completo.

E1 - (...)

Pesquisadora - Você é de que área? Qual sua especialidade?

E1 - Psicóloga.

Pesquisadora - E desde quando você trabalha com usuário de drogas?

E1 - Eu entrei aqui no PROAD, sempre foi aqui no PROAD, em 2009. Entrei como estagiária, era estudante ainda de Psicologia. Em 2009 comecei, em 2010 me formei e continuei. Então desde lá nunca parei.

Pesquisadora - Você trabalha com os grupos de triagem e com atendimento individual.

E1 - Isso.

E1 - Pela sua experiência... Não. Na verdade não é grupo de triagem. É grupo de acolhimento.

Pesquisadora - Grupo de acolhimento. Desculpa. E com terapia individual.

Pesquisadora - Terapia individual. Psicoterapia. Pela experiência aqui no PROAD, você acha que pode citar alguns fatores que são associados à busca pelo tratamento? Recorrentes? Algumas situações que eles trazem como recorrentes, como ensejadoras para a busca do tratamento?

E1 - Eu acho que a primeira coisa que eu observo na maioria é a perda da qualidade. Então, perde total relacionamento com o mundo social. Quando são casados, o casamento acabou, quando têm filhos, o filho não quer mais ver, eu acho que a primeira coisa que eu vejo em massa é o final do seu relacionamento social com a vida, da sua qualidade de vida. Depois vem, acho que em alguns casos, questões de saúde específica; mas aí eu acho que mais quando a gente está falando do uso associado álcool, que o álcool traz um problema físico 
mais concreto de se analisar, clinicado, diagnosticado. Acho que, em massa, são esses dois que eu vejo, assim.

Pesquisadora - Também, do que você tem aqui nos tratamentos individuais em grupo, quando eles param, interrompem o tratamento, também tem alguns fatores que podem ser considerados recorrentes? Pela sua experiência?

E1 - Do motivo de parar o tratamento?

Pesquisadora - Parar. O que afasta?

E1 - A dificuldade de se manter limpo, não é? Ou seja, a busca pela droga, a busca pela droga de uso. O abuso. E mais uma vez eu acho que a falta do apoio social que faz com que a pessoa não consiga manter por um longo tempo o tratamento.

Pesquisadora - Quando você fala de apoio social, você fala exatamente do que?

E1 - Em primeiro grau, da família, ou de algum parente próximo e, depois, de um ambiente social. Trabalho, comunidade ou um tratamento perto de casa, ou uma questão mais saúde pública, vamos dizer assim. De rede.

Pesquisadora - Você acha que, de alguma forma... óbvio. Eles têm algum problema de saúde, mas você acha que, de alguma forma, por serem usuários de drogas, eles sofrem algum tipo de preconceito?

E1 - Com certeza, com certeza. O estigma é muito grande ainda nos dias de hoje. Como sendo usuários de drogas, como sendo violentos, então, eles vão sendo associados a vários estigmas, não é? então, é violento, a pessoa é vagabundo. Enfim, todos esses adjetivos horríveis eles são...

Pesquisadora - E você acha que eles sentem? Que eles percebem?

E1 - Percebem. Percebem, principalmente no grupo de acolhimento que a gente consegue ter esse retorno deles. Hoje mesmo, eles estavam falando muito de: "Não quero que ninguém saiba, porque não quero contar para todo mundo que eu agora estou fazendo um tratamento. Pesquisadora - Vou entrar já num termo especificamente, mas dentro doesse raciocínio do preconceito, você acha que o fato das drogas serem criminalizadas, aí principalmente, as drogas ilícitas, eu falo mais do crack, você acha que isso reforça algum tipo de estigma ou que eles são estigmatizados independentemente da licitude do dano ou da ilicitude da substância?

E1 - Eu acho que reforça. Eu acho que reforça. Não é simples a gente analisar tão assim, mas eu acho que reforça, porque a droga ilícita já está à margem e aí a pessoa, o usuário, está mais à margem ainda. 
Pesquisadora - Dentro dos próprios usuários.

E1 - Isso.

Pesquisadora - Está. Como que você percebe, se você já percebeu, se alguém já relatou isso, a relação deles com polícia e Justiça?

E1 - Olha, que acho que muito variada, viu? Acho que não tem, pela minha experiência, não tem um padrão. Mas, enfim, eu não conheço muitos que foram pegos. Só alguns que tiveram problemas com a polícia, que relataram e tal. Mas o que eles relatam é assim: "Olha que sorte. Nunca fui pego". Enfim, hoje mesmo um estava falando: Eu trabalho de motorista e sempre dirigindo embriagado. Sempre dirigindo sob o efeito. E nunca fui pego. Ai que sorte”. Então, eu acho que tem sim um medo da polícia, um medo de você ser pego, mas nunca vi ninguém relatando o fato em si que aconteceu. Não sei se é mais ou menos isso que você...

Pesquisadora - É. É sim. Que tipo de estratégia... Acho que tem um pouco a ver com aquele aparato social que você já falou, mas eu vou só reproduzir só a pergunta que está aqui. Quais estratégias você acha que seriam importantes para incentivar o usuário - e aí o usuário específico de crack - a buscar o tratamento? Você acha que tem alguma atividade que possa influenciar, que possa ajudar a esse primeiro passo? Ou acha que é uma coisa mais subjetiva dele mesmo.

E1 - Não. Eu acho que dá para a gente trabalhar como saúde em geral para estimular essa pessoa a procurar um tratamento, mas eu acho que a estratégia é sempre ir para a rede social. A gente precisa, antes de falar para essa pessoa parar de usar, a gente precisa olhar para essa pessoa e ver o que está faltando na vida dela. O que fez ela chegar ali. Agora, é lógico que não dá para fazer isso individual, num primeiro momento. Tem que ter uma política que vai abrange mais ou menos todo mundo, mas através do serviço social. A gente precisa ter uma rede social que suporte essa pessoa para dar e depois a gente falar de ficar limpo, de parar de usar.

Pesquisadora - E aí, dentro desse contexto de uma aproximação de serviço social, você acho que o primeiro contato, através da repressão, afasta ou aproxima o indivíduo?

E1 - Afasta. Afasta totalmente, porque você entra por outro viés. Você entra pela imposição e pela força. E não pelo acolhimento. Porque essa pessoa que está na rua não tem família. Ela perdeu a perspectiva de vida, não tem nenhum objetivo pelo qual ela pode ser movida a sair dali. Se a gente fortalecer esse outro lado social dela, que seja um prato de comida, um 
lugar para ela dormir, tomar banho, um trabalho, eu acho que é mais por aí que a gente tem abordar no início. Não sei nem se é no início. Acho que todo o tratamento.

Pesquisadora - E você acha que se por acaso o uso de drogas fosse descriminalizado, eu não estou falando da substância em si, mas do porte para uso, uma pessoa surpreendida com um cachimbo e uma pedra de crack, isso já é uma conduta tida como criminosa. Penas diferentes, mas criminosa. Você acha que a descriminalização dessa condutafaria com que o uso aumentasse?

E1 - Difícil de responder.

Pesquisadora - É que eu tenho que perguntar, porque às vezes a questão prática dá para sentir.

E1 - Eu não sei se mudaria tanto não. Eu não sei porque... Eu tenho minhas dúvidas, mas eu acho que não mudaria muito não. O uso, porque, em geral, quando a pessoa já está num nível muito aprofundada de uso, não sei... acho que não faria tanta diferença não para aumentar esse limite. É isso que você quiser dizer, não é? Aumentar esse limite para ser considerado um crime.

Pesquisadora - Como profissional de saúde que lida com todos esses usuários, se você pensar numa situação hipotética de você como usuário de crack e tivesse que fazer essa primeira aproximação, você gostaria que a primeira aproximação fosse só da saúde ou que a repressão viesse junto?

E1 - Só da saúde, sem dúvida. Só da saúde. Acho que aguentaria muito mais adesão e muito mais eficácia no tratamento. Eu acho.

Pesquisadora - Está bom. É isso. 


\section{ENTREVISTADO: E2}

Arquivo de Áudio:130807_003

Tempo: 00:08:22

Pesquisadora - Eu preciso do seu nome completo.

E2 - (...)

Pesquisadora - E a especialidade?

E2 - Sou psicóloga clínica. Especialista em análise jungiana e neuropsicologia.

Pesquisadora - Desde quando você trabalha com usuário de drogas?

E2 - Faz um ano.

Pesquisadora - Um ano. E a referência toda foi aqui no PROAD?

E2 - Foi no PROAD.

Pesquisadora - Você aqui no PROAD faz o quê?

E2 - Eu faço avaliação dos adolescentes e trabalho no Grupo de Acolhimento de Mulheres e no Grupo de Psicoterapia para Mulheres.

Pesquisadora - Tudo em grupo? Não têm terapias individuais?

E2 - Não. Eu não trabalho com as terapias individuais. Esse serviço existe aqui no PROAD, mas eu não faço.

Pesquisadora - Pela experiência desse um ano trabalhando com usuários, se você pudesse listar alguns fatores que você acha que trazem eles para o tratamento, que faz eles refletirem sobre a necessidade de se tratar, tem algum que você pode dizer ser recorrente? Que você acha que tem um pouco mais de força?

E2 - Eu acredito que, em primeiro lugar, por uma questão de saúde. Muitas vezes eles vêm procurar o serviço porque estão com algum tipo de problemas físicos. Depois, com a precariedade da vida. Quer dizer, eles ficam muito aquém do que eles poderiam estar. Quer dizer, têm uma vida muito prejudicada por conta do uso de drogas.

Pesquisadora - Então, são os dois que mais... E se eles param? Deve ter muita gente que interrompe o tratamento.

E2 - Sim.

Pesquisadora - E tem alguma coisa que você possa associar a isso? Por que... 
E2 - Por que interrompe? Porque muitas vezes não conseguem lidar com as frustrações, com as dificuldade. Então, por eles serem pessoas, com uma formação egóica mais frágil, eles não conseguem lidar muito com essas dificuldades e acabam recorrendo nas drogas.

Pesquisadora - Então, a droga, na verdade, na maioria dos casos, seria uma decorrência de alguma outra coisa um pouco mais complicada?

E2 - Exatamente.

Pesquisadora - Não seria o problema primeiro?

E2 - Não.

Pesquisadora - Tá. Você acha que os usuários se sentem diferentes das outras pessoas? Por serem usuários de drogas, que eles se sentem marginalizados, existe algum preconceito?

E2 - Eu acredito que sim. Acredito que sim. Sempre quando eles vão se apresentar, eles nunca falam as coisas que eles fazem, a profissão que eles têm. Eles sempre associam seu nome com o uso da droga que eles utilizam.

Pesquisadora - Entendi.

E2 - Então eu vejo que tem, assim, um preconceito deles próprios com relação ao uso e tem um sentimento de rejeição. De que eu sou pior que os outros, sou diferente, sou mais frágil. Pesquisadora - E dentre os usuários, existe essa diferença também de se sentir ainda menor com relação aos usuários de drogas lícitas e das ilícitas?

E2 - Sim. As drogas mais pesadas, eu escuto gente falando: “Ah, mas você é só usuário de álcool. Você não sabe o que é ser usuário de crack. É muito pior”. Quer dizer, você desceu muito mais, você está mais decadente do que um usuário de álcool. Não é? Por exemplo, o álcool é uma droga aceita. Muitas vezes eles acham que por serem usuários de crack são piores. São mais decadentes.

Pesquisadora - E aí, como profissional, você acha que essa diminuição deles próprios pode afetar negativamente o tratamento? Esse fato de se sentir pior?

E2 - Ter uma autoestima ruim? Você está me perguntando se isso pode dificultar o tratamento? A questão da autoestima? Acredito que sim, porque fica um círculo vicioso. Minha autoestima é rebaixada, porque sou usuário de drogas. Eu não consigo lidar com a abstinência e isso me torna pior ainda. Então, muitas vezes, elas fogem porque tiveram uma recaída. Aí têm vergonha de vir e dizer que tiveram uma recaída. E a gente trabalha muito essa questão. Não. Se teve uma recaída, aí é que tem que vir mesmo. Tem que vir. O grupo vai acolher. Não existe um tratamento se não houver uma recaída. 
Pesquisadora - E você acha que de alguma forma, o fato do porte para uso ser considerado crime, então, dessa pessoa estar inserida no status de criminoso, isso pode também reforçar a ideia negativa que eles têm? Ou você não teve ninguém que citou isso como problema? E2 - Eu não tive ninguém que citou isso como problema, mas eu vejo que... Eu acho que isso incentiva a pessoa a procurar um tratamento. Assim, inconscientemente ela está sabendo que está fazendo uma coisa errada. Pode ser presa por isso. Então, acredito que isso também deve incentivar o tratamento.

Pesquisadora - $O$ saber que é crime.

E2 - Saber que é crime.

Pesquisadora - Incentiva ao tratamento.

E2 - Incentiva o tratamento. Eu acredito que sim.

Pesquisadora - Tá. Se a abordagem feita pela polícia pudesse ter viés repressivo ou viés acolhedor, se tivesse que escolher para um usuário de crack a abordagem da polícia ou a abordagem da assistência social, você acha que qual das duas seria mais eficiente?

E2 - Assistente social.

Pesquisadora - E você acha que, de alguma forma, o "repreender" pode prejudicar a ideia do tratamento? Que essas coisas têm uma incompatibilidade para andarem juntas ou que é possível repreender e incentivar a se tratar ao mesmo tempo?

E2 - Eu acredito que seja possível sim.

Pesquisadora - Então...

E2 - Porque eu acho que existem pessoas que não vão entender de outra forma a não ser com a repressão. Eu acho que no país que a gente vive, eu acho que tem que ter a repressão e tem que ter o acolhimento. Tem que ter as duas coisas. Se fossem pessoas mais conscientes, eu acredito que só o acolhimento teria resultado. Mas como as pessoas, muitas vezes, são inconscientes, muitas vezes são ignorantes, a repressão precisa existir também. Pelo menos por enquanto, a meu ver.

Pesquisadora - Aí vou te falar a última pergunta, que tem a ver com isso que é: Qual a sua opinião sobre a criminalização do porte para uso pessoal. Não das drogas.

E2 - A minha opinião sobre a criminalização do...

Pesquisadora - Do porte.

E2 - Do porte. 
Pesquisadora - O tráfico de drogas e as substâncias são ilícitas e são proibidas, mas hoje em dia é proibido também portar para consumo pessoal. Eu não posso ter um baseado nem uma pedra de crack comigo.

E2 - Você está me perguntando se eu concordo...

Pesquisadora - Se você acha que é efetivo ou não é efetivo, se os pacientes mencionam? Foi uma novidade eu te dizer que o porte para uso é crime?

E2 - Não. Eu já sabia que o porte é crime e que se você portar... O usuário não. O usuário não é criminoso.

Pesquisadora - É.

E2 - Também.

Pesquisadora - Também.

E2 - Ah tá.

Pesquisadora - Com medidas diferentes da prisão, mas também é criminoso. O crime está previsto no Art. 28 e ele pode ser apenado com advertência, prestação de serviço à comunidade ou comparecimento obrigatório a cursos sobre os efeitos das drogas. Não é uma pena privativa de liberdade, mas é uma pena.

E2 - Então você está me perguntando se eu acho que é efetivo a pessoa ser uma criminosa por estar portando uma droga ilícita? Eu acredito que sim. Sim. Apesar que nosso sistema é muito ruim. Nosso sistema prisional. Se tivesse uma orientação dentro da prisão. Mas o que vai fazer? Eu acho que tem que ser crime e depois a gente precisa batalhar para ter um sistema melhor, que oriente. Atendimento de saúde, policial que oriente melhor as pessoas, que dê um suporte. Por exemplo, os usuários de crack, Cracolândia. Não adianta você reprimir aquelas pessoas. Você tem que dar um outro tipo de tratamento. Um outro suporte. As pessoas precisam ter alguma coisa para fazer, ter um objetivo na vida.

Pesquisadora - Precisa, então, talvez ter uma coisa pensada mais individualmente, não de uma forma geral, para cada paciente, para cada indivíduo?

E2 - Se desse para fazer isso seria ótimo, não é?

Pesquisadora - Entendi. É isso.

E2 - Está. 


\section{ENTREVISTADO: E3}

Arquivo de Áudio:130807_003

Tempo: 00:12:54

Pesquisadora - Qual seu nome completo?

$\mathbf{E 3}-(\ldots)$

Pesquisadora - A sua especialidade?

E3 - Sou psicóloga.

Pesquisadora - Você trabalha com usuários de drogas desde quando?

E3 - Dois mil e cinco.

Pesquisadora - E toda a atividade foi aqui no PROAD?

E3 - Foi.

Pesquisadora - Aqui no PROAD você faz o quê?

E3 - Eu coordeno o serviço de mulheres. Formei esse serviço e coordeno esse serviço e trabalho também no serviço de adolescentes, mas aí só como acolhedora.

Pesquisadora - Pela sua experiência aqui no PROAD, então, existem alguns fatores repetidos que são relatados pelos usuários quando eles buscam tratamento? Como ensejadores da busca?

E3 - Posso falar mais pelas mulheres. As coisas que eles repetem. Primeiro tem vergonha, é sempre um sentimento, a autoestima baixíssima, uma sensação de que são péssimas mães, as que são mães. O sentimento de culpa. Eu acho que a coisa mais repetitiva e mais importante nelas é essa coisa de uma culpa horrorosa. Nos adolescentes, eu acho que eles também nesse papel de adolescente mesmo, de ir contra, se é governo é contra, contra qualquer coisa e essa sensação de impunidade, de que não tem problema nenhum. Todos trazem uma relação importante com a mãe. A grande maioria é isso.

Pesquisadora - Então, você acha... Você falou muito das mulheres. Os adolescentes eu não entrevistei porque eu precisaria...

E3 - Das mulheres?

Pesquisadora - É. Então é melhor falar só dos adultos.

E3 - Ah, tá. Eu posso falar mais das mulheres. A questão das mulheres é séria porque existe uma questão social ainda muito grande com respeito às mulheres. Então, assim, se você pegar a faixa etária a partir de 40, são sempre alcoolistas, são mulheres que bebem 
escondidas, todas relatam beber escondido, todas têm vergonha do que fazem. Todas acham que a culpa é toda delas. Então, assim, é uma questão muito social. Porque se você pegar um homem que bebe, é um vagabundo ou é um bom vivant. Enfim, mas não tem essa conotação superpejorativa. Então, para as mulheres, fica muito mais pesado. E essa prática de beber escondido, a partir de uma determinada faixa, a partir da meia idade é praticamente unânime.

Pesquisadora - Entendi. E aí você acha que para as drogas mais pesadas, tipo crack, tem algum fator repetido também? Esse elemento culpa está presente?

E3 - Acho que sim. Nas que são mãe, claro, porque, assim, como é que uma mãe pode ser usuária de crack? Tenho medo de perda... Todas que têm filhos, sempre com medo de perda... A maior parte, da guarda dos filhos. Outro fator em comum em todas as mulheres, todas, as do crack também, frequentemente o primeiro uso é com o parceiro, que eu acho que diferencia muito dos homens. Os homens eu acho que fazem isso sozinhos. As mulheres, o uso delas é em função do companheiro, na maior parte, mesmo as mais novas. Porque você pensar que tem uma diferença entre usuário mais velho do usuário mais jovem tem mesmo. São as mais jovens... Se bem que a gente viu mais velhas que fumavam crack, mas a maior parte são mulheres mais jovens. A gente teve muitas grávidas usuárias de crack. Então, essas mulheres se sentido superculpadas. E muito mal de usar crack, mas uma coisa que foge ao controle delas. Mas a vergonha está aí sem tirar nem por.

Pesquisadora - E aí você acha... Eu acho que eu posso concluir isso. Que elas se sentem diferentes das outras pessoas. Têm um preconceito direcionado a elas...

E3 - Específico a elas. As usuárias de crack, a primeira coisa, a gente pensou uma época em montar uma preparação para as mulheres do crack ficarem no grupo, porque a gente... Primeiro que você tem uma aderência baixíssima das usuárias. Isso é unânime e eu sei que não é no PROAD. É difícil fazer essas mulheres fidelizarem ao tratamento até pela dinâmica do crack. Se você fizer conta. Então, elas sempre chegam aqui com uma coisa que tem que ser "hoje", elas têm que ser atendidas, tem que começar hoje, já, agora. E, muitas vezes, você atende essa demanda do "hoje, já, agora”, elas não voltam na próxima. Então, isso é unânime, essa demanda, essa premência em tratamento e a dificuldade de elas fidelizarem o tratamento. Tanto que a gente pensou, mas agora a gente até conseguiu porque é muito difícil o crack, não é? São as que menos a gente consegue "sucessos", vamos dizer assim. Muda de padrão de uso. Quem muda de padrão de uso? Quem a gente consegue mais coisas? Elas pararem de usar em alguns meses a gravidez ou quando estão aleitando. Mas muitas vezes 
elas voltam a usar depois. Então, já é uma clínica que você tem muito menos sucesso do que normalmente você já não tem muito sucesso com as clínicas da dependência, não é? A do crack menos ainda. E aderência menos ainda.

Pesquisadora - E você acha que além do padrão de uso, que influencia nessa baixa aderência, esse fato da autoestima ser ainda mais baixa...

E3 - Pior porque o crack é o pior do pior. Se você pensar que o crack, como dependência aqui no Brasil, quando você chegou no fim da linha, ainda se imagina uma mulher como usuária de crack. Ela é mais do que fim da linha.

Pesquisadora - Então, e aí? Essa propaganda que a gente tem hoje no Brasil do crack como fim da linha, pode ser um reforço negativo para adesão ao tratamento? Em vez de positivo? E3 - Olha, eu posso pensar que sim porque você... Não sei por que... Veja. Fumar crack, ou você está fumando e fumando, o que elas trazem, ou você está querendo parar, querendo parar. Quando você está fumando, você nem pensa na possibilidade de fazer tratamento. Quando você está querendo parar, você pensa na possibilidade de fazer tratamento, mas você se sente horrorosa. E a gente fez questão aqui de não fazer um grupo específico de crack, como tem muitos lugares que fazem, porque fica sectário do sectário. Eu não sou a favor de fazer grupo de álcool, grupo de crack. Acho que não tem nada a ver. Porém, elas, quando se colocam no grupo, elas se consideram... Elas morrem de vergonha. Elas morrem de vergonha. Elas acham que estão todos julgando elas por serem usuárias de crack. E uma das coisas que eu acho que é superimportante para o tratamento é elas chegarem no grupo e se darem conta que as outras se consideram iguaizinhas a elas. Isso, eu acho também que é uma peculiaridade do grupo de mulheres, porque as mulheres funcionam de fato, assim, a mulher... É muito peculiar o grupo de mulher do que um grupo misto ou um grupo de homem porque mulher tem essa coisa de logo criar um círculo, de uma relação afetiva se estabelecer, de uma relação de intimidade se estabelecer, de uma relação de falar de si com a outra. Mulher gosta de "papo cabeça". Então, o grupo não é um grupo que gira só em torno da droga. Diferente de um grupo masculino ou um grupo misto que eles basicamente falam de drogas. Você vê mulheres muito graves, elas estão falando de que? Estão falando de filhos, de maridos, de parceiro ou do dia a dia delas. Quer dizer, elas trazem as questões pessoais delas. Então, fica muito claro que tem toda uma questão de dinâmica seríssima no uso de drogas. Então, é um grupo muito íntimo, muito afetivo, muito esponjoso. Claro que tem brigas, porque mulheres também têm essa coisa. Quanto mais íntimo você fica, mais você vai brigar. Se você tem pouca intimidade... Quando mais você cria uma relação. Então, elas 
estão sempre muito preocupadas com as outras. Tem a peculiaridade, como é um grupo mais poroso, porque mulher sempre cabe gente dentro, não é? Então, por exemplo, acabou de ter neném, traz o filho. Está dando de mamar junto. Então, é um grupo poroso. Cabe criança pequena quando não teve com quem deixar. Então, é uma peculiaridade. Então, assim, o que você precisa é quebrar essa barreira para elas se sentirem acolhidas, mas muitas vezes a gente não consegue que isso aconteça. E elas vão embora. Não só pelo uso, mas eu acho que muito também por não se identificar, por se sentir diferente: "Está todo mundo achando que eu sou a pior de todas", entendeu?

Pesquisadora - Entendi. E aí, dentro dessa ideia, pensando numa primeira abordagem de uma mulher, já que a gente está falando das mulheres, usuárias de crack, você acha que uma primeira abordagem repressiva pode afastar?

E3 - Claro que afasta. É óbvio. Sim, também, você sabe. A política do PROAD... A repressão aproxima quando? Eu acho que não é com respeito ao crack. Eu acho que é com respeito a qualquer outra coisa. Se você quer que alguém venha te procurar, você acolhe. Se você começa já a botar o dedo no nariz da pessoa, é óbvio que ela não vem te procurar. Ela está frágil, ela está precisando de ajuda, ela está com vergonha. Vem alguém já mostrando: "Que vergonha". O que você faz? Você vai embora. Você foge. Essa é a pior política que você pode querer ter para alguém vir buscar ajuda.

Pesquisadora - E algumas das pacientes já relataram alguma relação com polícia ou Justiça? E3 - Todas. Todas. A maior parte, porque uma das coisas principais aí não é a peculiaridade das mulheres. De quando você começa a ter muito, assim, a fazer um uso compulsivo, você acaba sendo pego pela polícia. Nossa, elas relatam direto o abuso, a agressividade, a violência, a manipulação. Todas.

Pesquisadora - Então, nunca um relato acompanhado de uma reflexão positiva?

E3 - Polícia? Polícia para dependente químico? Polícia é bandido para dependente químico. Polícia usa eles, polícia bate neles, polícia rouba drogas deles.

Pesquisadora - Então, você acha que não existe coerência numa política que prega como principal objetivo o tratamento e reinserção do usuário, mas que permanece mantendo o usuário na posição de criminoso?

E3 - Protecionista, superpatriarcal, certo e errado, pode ou não pode. Isso nunca funciona com dependente químico. Existem certos comportamentos, certos tipos de defesa que se você bater de frente, foge. Esse tipo de comportamento do usuário, que é um comportamento delinquencial, vamos dizer assim, ele tem a ver. É um comportamento delinquencial porque 
você está fazendo uma coisa contra a lei, para os usuários de crack, não é? Além do mais que crack é muito ligado a essa coisa de que elas fazem qualquer coisa para ter pedra. Todas que moraram na rua relatam mesmo que ou se prostituem ou vende tudo ou pega coisa. Enfim, elas sabem, porque eu acho que não é só pelo uso do crack. É pelo fato do crack te levar a um comportamento tão compulsivo, cria uma adição tão profunda que você está fazendo qualquer coisa. Veja, a questão, assim, não é porque você usa crack que você vai ser mais violento. Esse comportamento de violência já tem em você. Então, não vamos dizer que todo usuário de crack é bandido. Não é essa a questão. Mas é claro que seus limites, seus bordos ficam um pouco mais abertos em função da premência do uso. Agora, se você vai tratar, fazer a clínica de um determinado tipo de comportamento que acompanha todo usuário ide drogas que é "delinquencial”, ou seja, você faz alguma coisa errada usando o seu ego. O ego vai junto com você. Usa a sua vontade também para fazer. Então, a gente chamaria "comportamento que tem muitas defesas psicopatias", ou seja, antissociais. Por que antissociais? Porque é errado para a sociedade. E você vai reprimir essa pessoa? O que ela vai fazer? Ela vai espanar. Ela vai embora. O que você tem que fazer é: “Ok. nós sabemos que está errado. Aqui tem espaço para aguentar e para trabalhar isto que não é correto, que você está fazendo. Você traz para mim que não é correto, eu estou tentando te ajudar. Mas se você vem buscar tratamento, é porque você é dependente. Senão você não viria". Agora, se eu vou dizer: "Não pode. Vou te reprimir", você vai embora.

Pesquisadora - Então, a política criminal atrapalha a política de saúde?

E3 - Eu acho. Eu pessoalmente acho.

Pesquisadora - Tá ótimo. É isso. Obrigada. 


\section{ENTREVISTADO: E4}

Arquivo de Áudio:130807_003

Tempo: 00:11:40

Pesquisadora - Comecei a gravar. Primeiro preciso do seu nome completo.

$\mathbf{E} 4-(\ldots)$.

Pesquisadora - Sua especialidade?

E4 - Eu sou psicóloga, psicoterapeuta e terapeuta familiar.

Pesquisadora - Você trabalha com usuários de drogas há quanto tempo?

E4 - Vinte.

Pesquisadora - Vinte anos?! Aqui no PROAD todo esse tempo? E o que você faz aqui no PROAD?

E4 - Eu sou coordenadora da Área de Atendimento às Famílias. Sou psicoterapeuta. Então, eu atendo aos pacientes, faço um grupo de não-química e faço um grupo de químicas e faço os atendimentos de família. Dou supervisão para os especializandos de Psicologia tanto aqui do PROAD quanto do Departamento de Psiquiatria.

Pesquisadora - Pela sua vastíssima experiência, se você pudesse... E aí você não deve, pode me falar, mas existem alguns fatores que os usuários trazem como recorrentes para busca pelo tratamento? Que citaram na triagem, que fizeram com que eles chegassem até aqui?

E4 - O que normalmente acontece é que a coisa ficou preta na vida deles. Essa é uma coisa recorrente. A busca do tratamento tem a ver com a piora da qualidade de vida.

Pesquisadora - E aí relacionado mais com o relacionamento pessoal com outras pessoas? Com saúde?

E4 - Não. Com saúde, relacionamento, trabalho, normalmente precisa estar tudo muito ruim para eles irem.

Pesquisadora - É normal que eles tragam algum relato de problema com a polícia? Do Judiciário?

E4-É normal.

Pesquisadora - É normal?

E4 - É normal. Tem uma... A probabilidade é grande de eles estarem envolvidos com esse tipo de coisa. 
Pesquisadora - Mas é isso que faz com que eles busquem ou vem junto com o pacote?

E4 - Às vezes vem junto com o pacote. É mais junto com o pacote do que sozinho, porque tem pacientes que vêm só com essa demanda. Você tem demanda judicial. Normalmente é um paciente que não adere. É um paciente que vem mandado pelo juiz e acaba não aderindo. E é bem mais difícil de lidar.

Pesquisadora - Por que você acha que o paciente enviado pelo juiz tem essa dificuldade de adesão?

E4 - Porque normalmente ele não quer. Ele vem porque é uma imposição judicial, uma imposição judicial que ele tem que cumprir.

Pesquisadora - E aí o fato de ter sido imposto não incita uma reflexão que o faça permanecer.

E4 - Não. Não.

Pesquisadora - Não chega a ser um envolvimento natural?

E4 - É. É o que normalmente a gente vê.

Pesquisadora - Você acha que os usuários se sentem, no geral, diferentes das outras pessoas?

E4 - Se sentem.

Pesquisadora - Em que sentido?

E4 - Em todos. Eles se acham sempre menos do que a maioria das pessoas. São pessoas com uma autoestima muito rebaixada, se acham marginais, se acham pouco dignos da maioria dos privilégios que se possa ter na vida, são pessoas que sempre se acham menos do que qualquer outra pessoa.

Pesquisadora - E você acha que esse sentimento deles é uma decorrência do preconceito dos outros em relação a eles ou uma visão deles em relação...

E4 - Dos dois. Dos dois. E tem uma visão deles muito... Eles têm uma visão muito, um preconceito também em relação a essa condição de serem dependentes de substâncias.

Pesquisadora - E aí, dentro dos dependentes, você acha que existe um preconceito entre os usuários de drogas ilícitas em relação aos usuários de drogas lícitas?

E4 - Sim. Tem preconceito sim. É muito comum, já tivemos aqui momentos bem tensos de alcoolistas com usuários de outras drogas. Então, o alcoolista achar que é muito melhor ou ele é muito mais digno do que o colega que está no mesmo grupo, mas porque o outro faz uso de drogas ilegais. Então, ele, enfim, ele não é um drogado. Drogado é aquele que usa 
cocaína, crack, maconha, etc. E a bebida não. É menos. É menos grave. A pessoa não fica tão dilacerada, o que é um erro, um equívoco enorme.

Pesquisadora - E aí dentro dos usuários das ilícitas existiria também um preconceito em relação ao crack?

E4 - Não tanto. Não tanto, porque eu acho que uma boa parte dos dependentes já experimentou crack ou usa crack, entendeu? Crack hoje não é mais uma droga diferente. Todo mundo tem acesso a ela e, de alguma forma, muitos já experimentaram.

Pesquisadora - Entendi. E aí, então, voltar um pouco àquela relação de preconceito entre os usuários das lícitas e das ilícitas, o fato de uma droga, de uma substância ser ilícita não traria um reforço dessa sensação de inferioridade? Que seria prejudicial para o tratamento ou não?

E4 - Não.

Pesquisadora - Não. Você acha que isso não muda nada?

E4 - Acho que não muda nada, porque o fato de ser ilícita tem um significado muito importante. Um significado para aquela problemática psicológica daquele indivíduo. $\mathrm{O}$ indivíduo dependente, a ilegalidade é um dos fatores muito significativos nessa dinâmica.

Pesquisadora - Significativo de que forma?

E4 - De ser libertador, entendeu? De ser libertador, de ser, como posso dizer? Essa coisa de gravar me deixa procurando as palavras. De se contrapor às coisas vigentes, sabe? Tem uma coisa de se contrapor ao que está aí vigente e usar uma droga ilícita é bem essa... Dá bem esse significado para a situação.

Pesquisadora - Entendi.

E4 - Ela abarca essa necessidade de fazer coisas contrárias ao que é posto. Sabe?

Pesquisadora - Legal. Mas aí, então, eu posso concluir que talvez o fato de ser contra a norma, em alguns casos até incentiva o uso?

E4 - Incentiva.

Pesquisadora - Então não afasta o usuário do uso. Na verdade, em algumas situações pode até abrir espaço.

E4 - Em muitas, eu acho. Não é só em algumas. Acho que em muitas é um chamativo. Sabe? Por que alguém para enfrentar um problema não vai usar outros recursos e sim vai buscar o uso de substâncias ilegais? Porque tem um significado a substancia ilegal. É uma forma da pessoa se contrapor ao que é vigente. Entendeu?

Pesquisadora - Entendi. 
E4 - Apesar de ela se dar mal depois e ser paradoxal porque a dependência é algo que não é nada libertadora, mas no começo pode dar essa sensação de "liberdade", de "faço o que eu quero". Ninguém me segura.

Pesquisadora - E agora pensando numa abordagem, vou te pedir para pensar nos usuários de crack, porque são os que eu estou estudando, mas numa primeira abordagem do usuário de crack, pensando no fato de que o porte para uso é criminalizado, você acha que uma primeira abordagem repressiva podia afastar esse indivíduo do tratamento?

E4 - O que você chama de repressiva? O que...

Pesquisadora - Uma abordagem repressiva é uma abordagem pela polícia, ser levado para a delegacia, é o que a norma penal, na verdade, como você tem a criminalização do porte para uso, é uma ação criminosa. Apesar de ter medidas diferentes da prisão, a abordam, no geral, é feita pela polícia, o encaminhamento é para a delegacia e o trâmite todo vai correr junto à Justiça Criminal. Então, essa abordagem pode ser ou pela polícia, de uma forma repressiva, ou pela assistência em qualquer outra situação em que demande.

E4 - Eu acho que a repressiva tem menos chance de dar certo. Acho que afasta sim a possibilidade de coisas interessantes, entendeu? De tratar, de... Sei lá. Eu acho que uma abordagem mais acolhedora, uma coisa mais compreensiva da situação daquele indivíduo que não está usando crack porque simplesmente quer usar crack. Isso é uma incontingência da vida, um recurso que ele teve que usar para poder dar conta de uma série de coisas. Eu acho que uma repressão só faz fortalecer e incentivar mais o uso porque se deparar com situações muito difíceis que eles não sabem como lidar e lidam usando drogas.

Pesquisadora - Então formaria mais ou menos um círculo vicioso.

E4 - Vicioso. Quanto mais repressão, quanto mais violência, mais uso vai ter. Quanto mais pobreza, mais uso vai ter. Quanto menos possibilidades de uma vida razoável, mais uso de drogas vai ter.

Pesquisadora - Então, talvez o fato do uso das drogas ser criminalizada, aliado ao fato de que o porte para uso é repreendido também com essa força, poderia até gerar um aumento na procura pela droga já que a gente pensou em ir contra valores.

E4 - Eu acho. Eu acho. Eu acho que tem que ter essa coisa criminal, eu acho que essas penas tem que ter para traficante e não para usuário, para quem é dependente da droga. $O$ dependente da droga precisa de tratamento e não de polícia.

Pesquisadora - É isso. Obrigada.

E4 - Passou? Agora que eu estava animada. 
Pesquisadora - Quer falar mais? Te garanto que respondeu às minhas perguntas. 


\section{ENTREVISTADO: E5}

Arquivo de Áudio:130807_003

Tempo: 00:26:57

Pesquisadora - Comecei. Fala para mim, por favor, seu nome completo.

E5 - (...)

Pesquisadora - Qual a sua especialidade?

E5 - De formação, eu sou assistente social e tenho especialização em dependência química e sou mestre em saúde coletiva pela USP.

Pesquisadora - Que legal. Eu tinha um colega que é mestre em Saúde Pública, pode ser?

E5 - É um pouco diferente, mas tem a Faculdade de Saúde Pública.

Pesquisadora - Aquela na Zona Leste.

E5 - Não. Aqui na Doutor Arnaldo.

Pesquisadora - Não. Então estou confundindo.

E5 - A Faculdade de Saúde Pública é na Dr. Arnaldo, vizinha à de Medicina. Eu fiz Medicina Preventiva.

Pesquisadora - Eu fiz algumas matérias na Psiquiatria. Durante o mestrado eu fiz algumas matérias lá, apesar do meu mestrado ser em Direito, eu cursei três disciplinas lá. Desde quando você trabalha com usuários de drogas? Quanto tempo?

E5 - Têm mais de 10 anos.

Pesquisadora - E tudo aqui no PROAD?

E5 - Não.As minhas experiências foram bem diversificadas.

Pesquisadora - Você pode me falar um pouquinho?

E5 - Então, eu trabalhei na UNIAD (Unidade de Pesquisa em Álcool e Drogas), quem coordena é o Dr. Ronaldo Laranjeira, não é? Por quatro anos. Depois eu saí de lá, fui trabalhar no CAPS AD, no extremo sul de São Paulo, que fiquei alguns meses. Depois fui fazer mestrado, tal. E depois ainda tive uma experiência numa unidade de internação no Instituto de Psiquiatria, no GREA.

Pesquisadora - Olha. Bem variado.

E5 - É. Bem diversificada minha experiência. Daí o ano passado, depois que eu terminei o mestrado, que eu tive algumas trocas aí com o Thiago, que ele acabou me convidando para fazer o trabalho de supervisão da residente em Serviço Social. 
Pesquisadora - Entendi. E você acha que tem diferença do público entre esses lugares que você trabalhou?

E5 - É um pouco diferente, mas tem muita similaridade.

Pesquisadora - Isso é muito legal. Muito rico, não é?

E5 - É um pouco diferente, mas tem algumas similaridades. É que eu também trabalhei na UNIAD, eu trabalhei com um grupo de adolescentes. Eu trabalhei com famílias, eu trabalhei mais num ambulatório que era para usuários de álcool. Eu tinha alguns contatos com usuários de cocaína e crack, mas não diretamente. Indiretamente. Claro que no CAPS AD tem bastante. E na Unidade de Internação, no GREA, também tinha alguns casos graves.

Pesquisadora - Então, como eu faço a pesquisa com usuários de crack, nas perguntas que eu te fizer, se você puder pensar nesse público, bacana. E, se você puder falar, eventualmente, de alguma diferença que tem entre os serviçosfantástico, assim, porque é uma das primeiras pessoas que têm essa diversidade de experiências. Quando os usuários buscam tratamento? Você consegue pensar em alguns fatores que eles trazem de forma recorrente como ensejadores da busca? Então, eu estou aqui por essa razão.

E5 - Geralmente, a busca, pelo usuário, é quando já teve muitas perdas significativas na vida. Então, assim, até então, enquanto o uso dessa droga é um uso bom, positivo, digamos assim, recreativo, positivo, que traz sensações de prazer, ele não vem buscar ajuda. Ele vem buscar quase quando está lá no final do poço. Então, eu percebo assim, principalmente com adultos.

Pesquisadora - E o que para eles é o fim do poço?

E5 - Ah, muitas perdas, assim, quando já está em situação quase de rua, quando teve muitos conflitos familiares, de brigas, de discussões, quando perdeu o trabalho, que daí a perda da autonomia ou quando tem algum quadro clínico grave, considerável. Por exemplo, nos usuários de álcool, quando já estão acometidos de cirrose hepática. Por exemplo, os usuários de crack, quando já estão tendo algum efeito, por exemplo, alguma doença associada ao uso, tipo tuberculose, problemas pulmonares, não é? E outros. Aí é quando eles buscam alguma ajuda, mas mesmo assim com muita resistência.

Pesquisadora - Está. É comum que eles... Sei que não que é mais comum, porque não foi o que você trouxe, mas eles trazem muito relato de problemas com a polícia ou com o Judiciário?

E5 - Também. Tem os relatos dos atos ilegais, de criminalidade, de sempre ter cometido algum roubo, algum furto. Não digo a maioria, mas, sei lá, pelo menos metade já se envolveu 
com tráfico de drogas. Até para, às vezes, manter o próprio consumo. Ou não. Como também um negócio. Então, eu já cheguei a atender adolescente que era traficante de drogas sintéticas. É forte um pouco, mas, enfim, ele mantinha aquilo para o consumo dele e depois virou um grande negócio.

Pesquisadora - Entendi. Mas situações relacionadas à abordagem da polícia pelo uso puro e simplesmente ou aquelas medidas de encaminhamento ao tratamento é menos comum?

E5 - É menos comum.

Pesquisadora - Tá.

E5 - Eu não tive muito contato que o usuário chegou no serviço pelo encaminhamento de um policial. Não cheguei a ter esse... Eu sei que há alguns casos isolados, mas não cheguei a atender.

Pesquisadora - Tá. Você acha que existem fatores recorrentes para interrupção de tratamento?

E5 - Ah, eu acho que tem muito a ver com aquilo que a gente estuda em dependência química que é a motivação para o tratamento, venho dessa escola, que eles falam tão bem do ciclo motivacional para aderência ao tratamento. Então, assim, às vezes, começa até supermotivado porque tem um quadro clínico considerado grave, mas depois eles vão vendo que vai melhorando, vai diminuindo os sintomas, até consegue ter um uso controlado, ou às vezes, consegue ter um abstinência razoável. Aí quando eles veem que estão conseguindo se sentir melhor, aí eles começam a ter... Já não aderem tanto ao tratamento. Daí se a gente pensar nos estágios de motivação de mudança, está prevista a recaída, dentro da dependência química, embora a gente tenha um pouco de resistência a entender esse processo, mas está previsto. Então, ela pode acontecer em qualquer momento desse tratamento.

Pesquisadora - Entendi. Você acha que existem fatores que afastam o indivíduo do tratamento, alguma coisa que impede ele de buscar ajuda?

E5 - Olha, depende do serviço aí, do tipo como que o serviço vê essa questão do tratamento, mas às vezes, dependendo do serviço, do horário, dos dias que atende, pode ser um fator que bloqueie. Por exemplo, se uma pessoa ainda está fazendo tratamento, daí está trabalhando e o horário é só horário comercial, o serviço não dá uma opção de um horário noturno, por exemplo, pode ser um fator de dificuldade para ele acessar o tratamento. Mas eu acho que é muito mais... Assim, eu acho que os profissionais, todas as equipes, eu trabalho em várias equipes, os profissionais sempre se mantiveram dispostos a ajudar. Sempre numa postura de acolher, de ajudar, mesmo que o serviço não tivesse um horário tão estendido assim, mas 
sempre facilitava o processo. Não vejo muito da parte do serviço, talvez essa questão do horário da equipe. Mas é mais do usuário mesmo.

Pesquisadora - Entendi.

E5 - É ele que cria, muitas vezes, os próprios bloqueios, entendeu? E, às vezes, ele mesmo sabota o tratamento.

Pesquisadora - E essa postura de equipe? Uma postura acolhedora do profissional funciona melhor do que uma postura impositiva?

E5 - Funciona muito melhor e o fato, assim, existem artigos científicos que falam, assim, o simples fato de, por exemplo, o usuário não veio ao tratamento naquele dia e o profissional de referência fazer uma ligação para saber o que aconteceu. Se importar já faz grande diferença no tratamento. Às vezes, uma simples indagação, um simples contato pode melhorar a aderência dele ao tratamento. Então, essa postura acolhedora, de sempre estar ativamente ajudando, proporcionando uma escuta sempre acolhedora, de respeito, tentando compreender o lado dele é o que aumenta os fatores de proteção, que faz ter uma abertura. Mas eu penso que essa abertura vai até um ponto porque o usuário de substâncias, de uma forma geral, sempre está batendo de frente com as regras e com os limites. Então, assim, eu penso que o serviço precisa ser um pouco flexível e ter um tratamento adequado para cada caso, mas ele também precisa ter regras para esses usuários. Precisam ser colocados alguns limites, por exemplo, vir, frequentar um grupo sabendo que aquele dia, sei lá, há poucas horas, ele usou, sei lá, cocaína, crack ou tal. Como é que fica isso diante dos demais participantes do grupo? Eu penso ser complicado. Eu acho, assim, de repente o usuário chega aqui mal e tal, eu acho que o profissional até dá uma acolhida, mas sinaliza para ele que naquele dia fica difícil ele participar de um grupo, mesmo porque ele não está com seu raciocínio preservado. Ele está alterado. Se ele quiser alguma ajuda, passar no prontosocorro para ser medicado pelos efeitos do uso da substância, fornecer essa ajuda, encaminhar, enfim, mas acho que no processo de tratamento, vir alterado, até para os outros usuários que participam, por exemplo, de um grupo é complicado, porque parece assim: “Ah, então eu posso vir alcoolizado, eu posso vir aqui, usar não sei quantas pedras de crack e tudo bem. Posso vir aqui participar”, sabendo que a pessoa não está em sã consciência.

Pesquisadora - Entendi. E aí para seguir nesse mesmo raciocínio, você pensa que uma primeira abordagem do usuário, e tentando pensar no usuário de crack, ela funciona melhor sendo repressiva ou acolhedora? 
E5 - Ah, seguindo essa linha que eu estou falando, dentro do serviço. Eu acredito mais na postura acolhedora. Porque a questão repressiva que aconteceu aqui em São Paulo, não é? Acho que já vai para quase 2 anos que aconteceu aquilo, é comprovado que não deu certo. Tanto que, recentemente, eu li uma reportagem na Folha de São Paulo que aquela casa que fica lá no centro, que eles faziam uso, já tem novamente os usuários de crack lá. Então, aquela forma repressiva que a prefeitura, enfim, a Secretaria Municipal de Saúde, Estadual usaram, foi comprovado que não funciona. Pelo contrário. Espalhou um monte de usuários para tudo quanto é bando da cidade. Até eles ofereceram, acho que a Secretaria Municipal de Saúde tentou oferecer algum tipo de atenção com os consultórios de rua, mas efetivamente não aconteceu. Então, assim, acho que parte a gente lida com motivação do usuário no tratamento. Por isso que é tão desafiante. A gente oferece acolhida. Eu acho que a política, por exemplo, aqui no PROAD, que tem essa linha da redução de danos. De repente, aquele usuário não quer o tratamento, mas você pode tentar reduzir os danos desse uso. Oferecendo, por exemplo, para quem usa cocaína injetável seringas. Mesmo para os usuários de crack, quando a gente sabe que eles têm comportamento de risco sexual, oferecer preservativo, trabalhar essas questões com eles. A própria... O objeto que eles utilizam lá para fumar as pedras, de repente, um objeto mais limpo. Oferecer condições para que eles não venham a desenvolver pneumonia, tuberculose, hepatite, outras doenças graves. Então, eu acho que em alguns casos, a redução de danos vai auxiliar bastante, mas de uma forma acolhedora.

Pesquisadora - Tá. Você acha que os usuários de drogas, em geral, se sentem deferentes das outras pessoas?

E5 - Acho que eles se sentem excluídos. Porque eu lembro, assim, no CAPS AD que eu trabalhava com uma população mais de classe média baixa, classe baixa, muitos deles tinham vergonha de estar no grupo, de participar do grupo, de se expor. E daí eles falavam muito da coisa do preconceito no trabalho, que eles tinham que, muitas vezes, não tinham uma abertura, sei lá, com a assistente social, com a psicóloga da empresa para falar muito sobre a questão, que a empresa não via isso com bons olhos. Embora, hoje existam empresas que ofereçam programas de recuperação, investem até no funcionário, mas ainda tem muito preconceito. Preconceito não só no mercado de trabalho, mas, assim, de uma forma geral, pela população em geral. Nem todos veem... Eu tenho alunos, eu sou professora, dou aula para o Curso de Serviço Social, e eu vejo os alunos na graduação, embora eu trabalhe essa questão da saúde mental, essa questão da dependência química com eles, que é uma das áreas de atuação do assistente social, mas eu vejo muita resistência. Eu vejo muita resistência. Ah 
não. Vai muita para a coisa moral. Muito assim: "Não, o cara é vagabundo mesmo. Ele não está afim. Ele não quer se tratar. Ele quer ficar nessa vida aí usando”. Eu estou falando mesmo linguagem popular. Ele quer ficar usando mesmo. Não quer ter compromisso com a família. Não quer ter compromisso com o trabalho. É isso aí. Não assume nada. E, às vezes, não é isso. É falta de oportunidade. É falta de oferecer. É falta de acolher. De incluir em programas sociais, de pensar na efetivação dos direitos dessa pessoa, enquanto cidadão. Que ele tem seus direitos básicos. Precisa ser preservado. Direito à saúde, direito à boas condições de moradia, direitos básicos que são previstos na Constituição Federal. Então, eu tento trabalhar nessa questão da efetivação dos direitos que esse cidadão, independente da condição dele de usuário precisa ter.

Pesquisadora - E você acha que existe uma diferença de tratamento entre os usuários de drogas e lícitas e das ilícitas?

E5 - Diferença de tratamento?

Pesquisadora - Não. De tratamento das pessoas em relação a eles. Esse mesmo preconceito. E5 - Ah sim. Tem. Porque, assim, as drogas lícitas, teoricamente são aceitáveis pela população. Você fumar, você usar um cigarro de nicotina, você beber, tem gente que acha... Quem bebe, nossa. Fica mais sociável, uma pessoa mais alegre. Então, é um meio de socialização nos grupos, de uma maneira geral, até de ser aceito, não é? E a droga ilícita não. Ela já tem toda aquela estigmatização. Por exemplo, você pega um usuário de crack. Você pergunta para qualquer pessoa na rua, o que ele vai pensar: "Deus me livre. Está quase em condição de uma pessoa excluída socialmente, a maior parte fica em situação de rua, fica naquelas casas abandonadas. Vem aquela imagem meio que parece caracterizada como mendigo. Se arrastando pela rua. Então, é muito diferente. É muito diferente. Inclusive, tem um livro que fala dos vencedores viciados, que inclusive eu tenho esse livro antigo já, mas é de um rabino, que ele estudou e tal. E na Comunidade Judaica, que tem vários vencedores viciados. E daí ele fala dos grandes executivos, inclusive médicos, grandes profissionais e que fazem uso de substâncias. Ali na pesquisa fala muito do uso do álcool, enfim, mas tem as drogas ilícitas também. Do quanto que essas pessoas são para a sociedade vencedores, que conquistaram grandes coisas. Muitos têm grandes títulos, muita coisa importante, mas, por trás, são pessoas numa condição de viciados, mas que criaram uma máscara para a sociedade, mas por trás, para manter todo aquele padrão, muitos fazem uso de substância. Existem estudos sobre isso. 
Pesquisadora - Entendi. Quero desenvolver um pouco mais isso. Estou pensando na pergunta para não ser tendenciosa, mas esse estigma que a substância ilícita carrega, você acha que ela pode ser um "dificultador" na procura pelo tratamento?

E5 - Pode. Pode porque... Oi, tudo bom, Bart? Esse é o outro assistente social.

Pesquisadora - Ele é belga, não é?

E5 - Ele é belga. Você poderia entrevistar ele.

Pesquisadora - Então, ele não é da equipe fixa?

E5 - É. Ele não é.

Pesquisadora - A minha mostra é só da equipe fixa.

E5 - Ah que pena, porque daí ele traria a visão da Inglaterra e da Bélgica. Não, mas assim, como agregar valor, não é?

Pesquisadora - Eu participei do grupo de segunda-feira. Ele frequentou algumas coisas.

E5 - É. Então, você falava da estigmatização para...

Pesquisadora - O estigma que a condição de ilícito traz. Se isso pode ser um dificultador no tratamento.

E5 - Eu acredito que sim porque os próprios usuários, eles mesmos, se autodiscriminam, entendeu? porque, assim, aqui no PROAD a gente vê pessoas, usuários, que estão em situação de rua. Então, pensa bem. Uma pessoa que está fazendo uso de crack, que já está nessa situação de rua, excluído totalmente dos seus direitos, para ele chegar a um serviço de tratamento, imagine. Se não é por um profissional de saúde, ou quem sabe até um policial, digamos, que tem uma visão mais acolhedora, para chegar, nossa, vai levar quantos meses? Então, assim, o próprio usuário, às vezes, não tem forças para chegar a esse tratamento. Por isso que eu acredito que aquela abordagem de rua, dos consultórios de rua, desde que seja feito de uma forma acolhedora, respeitando a questão dos direitos dessa pessoa, acredito que ela funcione. E ir à rua onde eles estão e fazer essa abordagem e oferecer um acolhimento. Alguns até aceitam o tratamento. Não é assim: “Ah não". Alguns aceitam o tratamento porque eu conheço uma ONG que trabalha no centro da cidade. Tem uma ONG. Você já foi lá entrevistar?

Pesquisadora - Não. Eu conheço. É só aqui, na verdade, minhas entrevistas.

E5 - Ah, é aqui. Então, tem uma ONG que oferece. Várias ONGs, mas eu conheço uma delas que oferece essa ajuda. Então, muitos vão lá, tomam seu banho, tem a sua alimentação $\mathrm{e}$, às vezes, numa dessas abordagens, conseguem oferecem oferecer o tratamento e eles 
aceitam. Alguns não. E eu acho que a gente tem que respeitar o momento do usuário. Nem todos estão disponíveis naquele momento porque o estágio de motivação é oscilante.

Pesquisadora - Entendi. E aí você falou do policial eventualmente com uma postura acolhedora. Existem relatos dos pacientes sobre os policiais? Geralmente eles relatam...

E5 - Olha, os poucos casos, os casos que eu atendi, dificilmente eu ouvi alguma postura de um policial acolhedor.

Pesquisadora - Como é a postura de um policial?

E5 - Geralmente repressão. De repressão, de fazer aquela abordagem que eles fazem, de fazer... Que nem eu vi ontem lá dois rapazes sendo checados, porque eu acho que eles deveriam ter cometido furto. De ver se cometeu algum furto, alguma coisa, ver se está portando alguma droga, qualquer quantidade dessa droga, porque pela Política Nacional de Drogas, tem uma quantidade mínima que o usuário pode portar.

Pesquisadora - Na verdade, não. Não é a quantidade que diferencia. Você tem vários fatores para diferenciação do uso para o tráfico. Além da quantidade, as circunstâncias em que foi surpreendido. Não existe uma diferença quantitativa, mas qualitativa.

E5 - Mais quali... Então, mas poucas vezes eu vi algum relato... Não. Acho que nenhuma das vezes eu vi um relato de policial acolhedor. Mas eu sei que na polícia há policiais diferentes. Não é todo mundo que é dessa forma.

Pesquisadora - Claro. Eu estou perguntando o que você já ouviu deles.

E5 - Mas a maior parte é repressão.

Pesquisadora - Está. Aí a última pergunta, uma pergunta de opinião, que se você não se sentir confortável não precisa falar. O que você acha dessa política que mantém a criminalização o usuário, criminalizando o porte para uso pessoal? É uma estratégia que você acha que se harmoniza com a ideia de tratamento e reinserção social do usuário ou que pode contradizer um pouco a ideia, na medida em que coloca a abordagem com relação a ele como eminentemente repressiva, num primeiro momento, pelo menos?

E5 - Olha, eu acho que aqui na equipe aqui do PROAD começou a ter uma discussão sobre isso há umas duas semanas atrás. Eu acredito que essa política precisa ser revista, porque os profissionais de saúde trabalham do ponto de vista de saúde pública, de promoção da saúde. A equipe, de forma geral, de promoção, de acolhimento. E a política vai contra essa postura mais acolhedora, de promoção de saúde. Então, assim, às vezes, é um usuário que está portando só para o uso próprio dele. Por que eu vou ver isso como um ato infracional? Eu acho complicado. E a política de drogas no país não está clara. Nesse sentido não está clara. 
Ela dá margens... E é muito voltada para repressão mesmo. Então, eu acredito que precisa ser revisto junto com os profissionais de saúde, junto com os profissionais da área do Direito, da Justiça, com os policiais. Eu acho que precisa ser feita uma grande conferência, como foi feito quando foi implantado o SUS, não é? Que eu dou aula de Política Pública de Saúde. Então, foi feita uma grande conferência nacional, na década de 80, em 86, onde reuniu vários trabalhadores da área da saúde, enfim, para que pudesse ter um Sistema Único de Saúde universal, descentralizado. Enfim... E foi a partir daí que nasceu o SUS, que tem mais de 20 anos. Então, acredito que do ponto de vista de política, acho que precisa ser feita uma grande conferência, um grande debate com vários segmentos da sociedade.

Pesquisadora - Porque ainda falta conversa entre os profissionais e falta clareza nos objetivos?

E5 - Falta. E, assim, dentro da dependência química, a gente tem vários grupos. Uns são mais para a área de proibição, proibição e repressão. Daí tem os grupos que se voltam mais para essa questão da promoção da saúde, da redução dos danos, que o PROAD trabalha mais nessa linha. Tem outros que veem mais do ponto de vista biológico, médico. E não vê tanto a questão multidisciplinar. Então, assim, mesmo dentro dos profissionais da área de saúde mental, de dependência química, há diferentes posturas, diferentes visões. Só que do ponto de vista de política pública, a gente tem que tentar unir essas visões e o que é bom para o usuário. Então, não sei, é um grande desafio.

Pesquisadora - Obriga.

E5 - De nada. 


\section{ENTREVISTADO: E6}

Arquivo de Áudio:130807_003

Tempo: 00:10:28

Pesquisadora - Fala primeiro para mim seu nome completo, por favor.

E6 - (...)

Pesquisadora - Qual sua especialidade?

E6 - Sou psicóloga.

Pesquisadora - Você trabalha com usuários de drogas há quanto tempo?

E6 - Vai completar dois anos.

Pesquisadora - E todo esse trabalho que você desenvolveu com esse público foi aqui no PROAD?

E6 - Então, eu trabalho aqui no PROAD e faço mestrado com usuários de crack.

Pesquisadora - Ah que legal!

E6 - Então, assim, minha experiência começou pelo mestrado e eu vim buscar aqui no PROAD para poder complementar.

Pesquisadora - Entendi. O que você estuda?

E6 - Eu estudo o consumo de crack entre mulheres em situação de vulnerabilidade lá em Santos.

Pesquisadora - Ah que bacana. Então acho que essa entrevista vai ser bem boa. Essa é uma coisa que eu não te falei. Minha pesquisa é limitada aos usuários de crack para redução de amostra também. Então eu só falei com eles. Disse só do ... Mas a gente... Pela sua experiência de atuação e aí pensando nos usuários de crack. Não precisa, necessariamente, ser só mulher, mas pensando neles. Existe algum fator que você considere recorrente que enseje a busca pelo tratamento?

E6 - Geralmente quando eles buscam tratamento já estão, assim, naquela situação de não aguentar mais a vulnerabilidade pelo que eles estão passando, às vezes, procuram o tratamento por questões judiciais, por praticarem atividades ilícitas, aí acreditam que vão limpar a barra se estiverem em tratamento, por falta de moradia. Eu sinto que é muito competido o motivo. Porque às vezes, pode ser porque quer realmente abstinência ou controle do uso, às vezes é por questões legais e sociais. Não tem onde morar, não tem emprego, a família abandonou. Não sei se respondi. 
Pesquisadora - Respondeu. Quando eles procuram, você mencionou as questões legais. Quando eles procuram por motivos relacionados a esses problemas com a Justiça, geralmente é por um problema ligado à droga diretamente ou alguma coisa em decorrência, então, digo, ligado à droga é uma questão relacionada ao uso? Eu fui surpreendida pela polícia, é uma medida judicial por ser usuário de drogas ou furtei, roubei ou me envolvi com o tráfico? É um segundo...

E6 - É o segundo. Em decorrência. Geralmente por ter furtado, roubado, entre outras coisas para conseguir dinheiro para droga ou mesmo em favor, assim, fazer isso pelo traficante para conseguir a droga depois.

Pesquisadora - E você acha que existe, ainda nos fatores recorrentes, você acha que existe algum motivo recorrente para que eles interrompam o tratamento nos casos de interrupção? Ou é diversificado?

E6 - Acho que é diversificado. Eu acredito que pela impaciência de aguardar o efeito esperado. Em geral é isso. Geralmente tem muitas coisas competindo com o tratamento, principalmente o uso. $\mathrm{O}$ uso dá um efeito imediato. $\mathrm{O}$ tratamento vai demorar muito para conseguir, principalmente, abstinência, se é o que eles estão desejando. Para quem usa muito, conseguir parar tudo vai ser muito difícil. Então, a tolerância ao tratamento também acho que é algo que fica em desvantagem em relação ao estilo de vida. Não só ao uso, não é?

Pesquisadora - Você acha que os usuários, no geral, se sentem diferentes das demais pessoas por serem usuários de drogas?

E6 - Ah sim. Parece que a identidade deles fica restrita a ser dependente químico. A gente observa, assim, pelos grupos. Pede para apresentar: "Eu sou fulano, tenho tantos anos e sou dependente de álcool, crack, sei lá o que". Então, assim, o que mais? Você também é dependente, mas fica muito restrito, fica muito diretamente relacionado. Meu nome é isso e também sou dependente químico. De também estar aqui. Você percebe que quando você fala o nome 'droga', qualquer questão que você vai fazer, eles já se identificam totalmente. E parece que todo o resto da vida não é tão importante quanto.

Pesquisadora - Está. E você acha que dentre os usuários, existe ainda uma diferença entre os usuários de drogas lícitas e os usuários de drogas ilícitas?

E6 - Ah sim, com certeza. A gente também, pelo exemplo de grupo, os usuários de álcool, eles geralmente falam: "Não. Meu problema é só com álcool. Eu não uso outras drogas". Sabe que o álcool é uma droga, mas por ser lícita, então, assim, a gente sente que o tom da voz é: “Ah, tudo bem. É álcool. É lícito”. Cigarro eles nem comentam. A maioria usa cigarro 
e nem comenta, como sendo uma droga. Geralmente é de álcool para cima. Então, acho que tem uma escalada. Álcool, maconha, cocaína e crack que é o vim da linha.

Pesquisadora - Essa era a outra pergunta que eu ia te fazer. Você acha que existe um preconceito em relação, dentro dos usuários de drogas ilícitas em relação aos usuários de crack?

E6 - Há sim. É curioso, porque às vezes eles falam assim: "Nossa, aquele cara usa crack e nem parece". Então, o crack tem uma identidade, uma figura já formada. A pessoa que usa crack vai ser daquele jeito. Quem usa álcool, cigarro vai ser daquele jeito. Eles montam um estereótipo para cada tipo de droga.

Pesquisadora - E aí você acha que essas propagandas do governo, do jeito que a gente tem visto, de que o crack como um problema específico podem reforçar essa ideia do estigma? E6 - Com certeza, porque geralmente é ficar atrelado a situações extremas que cria medo, assim, a vontade de tentar eliminar essas pessoas. Acho que não reforça a necessidade de tratamento, mas reforça a necessidade por tirar essas pessoas do caminho. O lixo público. Ficou essa sensação.

Pesquisadora - E aí, eventualmente, como psicóloga, você pensa que um usuário, carregando todo esse estigma de ser o lixo público, ele pode ter uma dificuldade maior em procurar ajuda?

E6 - Com certeza, porque não necessariamente todos, mas eles já carregam junto ao estigma de usuário, pior ainda, ser usuário de crack e estar atrelado à criminalidade, à marginalidade, a ser um monte de outras coisas ruins, não é? Então eu acho que isso dificulta muito.

Pesquisadora - Você já teve algum relato de usuário sobre relação com polícia ou com Justiça?

E6 - Já.

Pesquisadora - E geralmente os relatos vêm de que forma? De uma ação acolhedora? De cuidado? De uma forma mais agressiva ou até violenta?

E6 - Repressiva. Geralmente, assim, os que a gente tem mais acesso é quando é extremo, não é? Quando é um furto, um roubo, eles não ficam mencionando muito, mas quando foi preso, que aí vai contar a história de vida, aí eles contam do período em que eles estiveram reclusos. Então, aí a gente já imagina como foi. Uma experiência muito punitiva. Eles não conseguem falar nada de positivo daquilo. 
Pesquisadora - E você acha que no tratamento para o usuário, pensando numa primeira abordagem, você acredita que para viabilizar esse tratamento, a primeira abordagem deveria ser acolhedora ou repressiva?

E6 - Acolhedora.

Pesquisadora - E aí, por quê?

E6 - Já é difícil chegar neles. Se chegar com intuito de repressão não vai se conseguir oferecer o cuidado porque já ficam muito arredios. Eu acho que tem que tentar abordar por questões que talvez não sejam diretamente ligadas às drogas, mas que consiga criar um vínculo. Então, acho que o acolhimento é a melhor delas. Acho que a proposta do consultório de rua, de chegar até eles de alguma forma para, dali, abrir o espaço para cuidado.

Pesquisadora - Você sente que algum usuário de crack, algum deles já te relatou isso, que, de repente, pensou em interromper o uso por ter medo da polícia? Eles conseguem ter essa consciência?

E6 - Eu acho que às vezes, não diretamente a polícia, mas é o fundo do poço que chegou, de levar uma vida que sabe que risco o tempo todo. Acho que de forma geral. Sei lá: "Olha aqui. Estou toda marcada. Já fui esfaqueada" relata vivências de muita violência. E aí envolve policial e eu acho que vem num todo. Não me lembro de falar: "Ah porque eu fui presa, eu quero sair dessa vida por causa disso". Mas eu acho que é um conjunto mesmo. Vem tudo junto.

Pesquisadora - Está. Então, pensando no usuário como profissional da área da Saúde, você acha que uma política criminal que mantém o usuário na condição de criminoso, pode afastar os indivíduos da atuação da saúde?

E6 - Ah, com certeza. Porque... Até, assim, dar um exemplo da minha pesquisa. Eles ficam com medo de responder à pesquisa achando que você vai entregar eles para a polícia e a verdade é que a gente não está fazendo um tratamento, mas a gente quer conhecer melhor a realidade deles para poder oferecer o tratamento. Então, você vê como já fica no imaginário deles. Qualquer intervenção voltada para eles já tem... Parece que tem um viés repressivo. Eles acham que vão ser prejudicados. Então, eu acho que, assim...

Pesquisadora - Tá. Obrigada.

E6 - Só isso? 


\section{ENTREVISTADO: E7}

Arquivo de Áudio:130807_003

Tempo: 00:27:27

Pesquisadora - Fala para mim seu nome completo, por favor.

E7 - (...)

Pesquisadora - Qual sua especialidade?

E7 - Sou psicóloga clínica.

Pesquisadora - Você trabalha com usuários de drogas há quanto tempo?

E7 - Desde 2007, ainda como estagiária membro da liga. Não é? Depois que eu me formei... Desde 2007, na verdade, não; desde 2006. Quando eu me formei, em 2007, eu fui convidada para fazer um grupo de acolhimento para familiares para a liga. Só que esse grupo não deu certo e aí eu fiquei fazendo acolhimento normal da liga com usuários.

Pesquisadora - Tá. Aqui no PROAD você desenvolve quais atividades? Faz atendimento no grupo ou faz individual também?

E7 - Atualmente só grupo. Num primeiro momento, quando estagiária ainda, eu fazia também individual.

Pesquisadora - Tá. Pela sua experiência, você acha que tem alguns fatores que podem ser considerados relevantes para que o usuário busque algum tratamento? Eles trazem algum fato comum?

E7 - Na verdade é o desespero, não é? Que os trazem para o tratamento e não é bem um tratamento porque eles não têm muita certeza se querem parar de usar porque aquilo é a única coisa que eles têm. Não é saudável, mas que dá vida, inclusive, para eles. Sem a droga, eles não são ninguém. Eles não conseguem se perceber. Eles não conseguem ser sem a droga. Então, a droga acaba dando a vida para eles, no sentido... Até o fato de eles irem buscar droga, de eles se drogarem, de eles, mesmo com todo o mal estar, tudo isso, é isso que os fazem estar vivos. Eles chegam num determinado momento em que a vida deles não tem sentido nenhum e a droga ainda mantém esse sentido,digamos assim.

Pesquisadora - Tá. E aí eles buscam, nessa situação de desespero não sei o que fazer, porque quero, não quero, existe uma dualidade? Existe um... 
E7 - Sempre existe uma dualidade, porque a droga é boa. Ela me dá prazer. Só que chega um momento que eu não acredito que não tenha mais prazer. Esse prazer vai sendo diminuído porque eles vão se dando conta dos prejuízos, das perdas.

Pesquisadora - E quais perdas eles citam com mais frequência?

E7 - Ah eu acho que a mais transborda, inclusive, na fala deles, o sofrimento é essa perda da família, do contato. É a perda de si mesmos, porque eles próprios não se reconhecem. Então, fica muito difícil porque ele mesmo não sente nada nem ninguém e, com o olhar dos outros, que só corrobora isso, eles ficam piores ainda. Na maioria das vezes, eles vêm, nessa busca do tratamento para poder resgatar essa família, resgatar alguém. De repente dar conta dessa solidão que vai se ampliando cada vez mais, porque eles vão ficando cada vez mais em função da droga, só que ao mesmo tempo em que ela dá prazer o que ela é companheira, a gente costuma até brincar com os casados, que é amante, não é? Existe uma solidão porque é só ela e ela não conversa, ela não transa, não faz carinho, ela não troca nada. Aquela prazer instantâneo da brisa e só. Depois não tem mais ninguém. Nada. Então, essa solidão também. É a busca disso. Tentar resgatar as pessoas. Passar na rua sem ser apontado. É o nóia, no caso dos olhos das outras substâncias. O alcoólatra, que ainda é esse termo que se usa no senso comum. E aí alcoólatra já vem carregado de vagabundo, incapaz, tudo isso.

Pesquisadora - Você acha, então, que os usuários se sentem menosprezados? Eles sentem o preconceito das outras pessoas? Se sentem diminuídos?

E7 - Sentem. Se sentem muito diminuídos. Isso me parece que é uma coisa que dói muito. E eles não se dão conta que isso é trocado. Eles também, por conta do uso das substâncias, eles também abandonam as outras pessoas. Não é que as pessoas abandonam por isso. Mas eles também vão se isolando cada vez mais por conta do uso, em busca da substância. Então, eles não se dão conta que eles também. Eu costumo dizer que às vezes, acho que eles abandonam primeiro e depois que eles começam a sentir a falta do outro, de fato. Quando eles estão sozinhos mesmo. Se sentem mais sozinhos.

Pesquisadora - E você acha que existe também uma diferença entre os usuários das drogas lícitas e das drogas ilícitas em relação ao preconceito?

E7 - Bom, hoje, por conta desse debate todo que existe sobre o crack, o preconceito é muito maior. Independente de ser crack porque as pessoas não sabem dividir. No senso comum, é tudo... Menos o álcool. O álcool não é droga, pelo senso comum, porque se bebe em casa, toda confraternização. Tudo tem álcool. É uma droga legal, logo não é droga. No senso comum. Então, um simples cigarro de maconha, que seja, experimentou a primeira vez já é 
um grande monstro. Inclusive, a gente ouve muitos relatos de que a maconha é que a causadora de todas as tragédias. No fundo, tem uma lógica, porque com o uso da maconha você pode propiciar o aparecimento de uma esquizofrenia, dar uma psicotizada bem bacana, uma coisa que pode não acontecer ao longo da vida, mas que com o uso da maconha você tem uma probabilidade maior de desenvolver, não é? Então, acho que as histórias dos relatos estão sempre em torno disso. Foram pessoas que tiveram suas experiências a partir do uso da maconha, desencadeiam uma esquizofrenia e daí a maconha é a grande "vilã". E aí eu fico sempre com aquela interrogação: "Não sei se é a maconha". A pessoa poderia surtar a qualquer momento. Só que com o uso da maconha apareceu e a maconha virou a mostra, ela que enlouquece e tudo isso. Mas alcoolista também não tem psicose induzida? Não tem demência? Não tem delirium tremens? Não vê bicho na parede? O que é isso? Principalmente para o senso comum que se o cara disser que está vendo bichos na parede ou andando nele, a pessoa, pronto, enlouqueceu. Fica bem ali.

Pesquisadora - E aí, de repente, essa propaganda política agora de o crack como o mal da sociedade moderna, você acha que, de alguma forma, pode aumentar esse peso? Esse estigma sobre os usuários?

E7 - Com certeza.

Pesquisadora - E você acha que isso tem reflexos na adesão ao tratamento?

E7 - Olha, não acho que tem reflexo na adesão porque o buraco é mais fundo. Para aderir ao tratamento, o cara precisa... É quase como querer renascer novamente. Ele tem que virar de alguma forma. Se virar do avesso, como eu digo, para que? Porque ele vai lembrar sempre daquelas substâncias de fuga, tudo isso, mas ele vai ter que tentar aprender a dar conta da vida como ela é, sem a fuga com as drogas, com a brisa temporária, sabe? Sem a fantasia. Ele vai ter que pôr os pés no chão e ir. E isso é muito difícil porque eu sempre digo pra eles o seguinte. Quando eles iniciam o tratamento, eles estão iniciando uma guerra deles contra eles mesmos. Ele não está guerreando contra um outro. É contra ele mesmo. Então, isso é muito delicado. Eles sofrem muito, por isso a dificuldade da adesão, por isso das recaídas. Ao mesmo tempo em que ele consegue ficar um tempão limpo e que está se segurando, tentando dar conta, às vezes um evento muito... Para a gente, na verdade, muito simples, muito corriqueiro, desencadeia uma recaída. Ele não dá conta. Quando a gente casa e tem filhos, por exemplo, a gente está fazendo essa opção, essa escolha. E aí chega um momento que não dá conta desses filhos e não dá conta porque é um outro, é um filho de 12 ou 13 anos que questiona, que cobra, que quer. Uma dificuldade muito grande de eles dizerem não 
porque, como eles se sentem à margem, eles acham que tem que sair realizando todos os desejos dos outros. Eles se põe como "super heróis em todos os sentidos. Tanto o alcoolista quanto os usuários das outras drogas nas relações familiares, tudo isso. Eles querem sempre tentar realizar o desejo do outro, a fantasia do outro. Se eles não dão conta de se realizarem. Então, é muito difícil.

Pesquisadora - Entendi. Seria, acho que, então, os fatores que aproximam, que afastam dessa possibilidade de se tratar seriam mais internos, até, do que externos. Seriam questões mais...

E7 - Eu acho que sim. Muito mais internos do que externos. E aí quando a gente vê todo esse boom do crack, toda essa chamada para o tratamento, toda essa disponibilidade de dinheiro, não sei o que, eles também têm uma coisa muito delicada, porque eles tratam como se fosse um todo. Eles não tratam a individualidade. Eles não vão pegar cidadão usuário de crack e conversar com cada, levantar a história de cada um, a necessidade de cada um. É uma coisa que é geral. Não se leva em conta a individualidade de cada um, as feridas, as dores, as perdas, tudo o que tem por trás daquele uso, daquela fuga da sociedade, para ir para a margem, para a sarjeta. Tem muitos rapazes, adolescentes que têm família, têm tudo, mas por não dar conta de viver naquele ambiente por "n" questões, prefere ficar na rua. Se drogando, no mundo da fantasia, teoricamente, sempre, não é? Porque daí é direto, porque é um atrás do outro, porque "não dou conta. Nem que eu tenha família. Nem que eu tenho nada, porque também que família é essa?" O pouco tempo que você ficou conosco aqui, não sei se você chegou a passar pelo grupo de família, mas os familiares não vêm. Eles não tem problema. O problema é o usuário. É o nóia. É o alcoolista. O resto da família não tem nada a ver com isso. E muitos lares, inclusive, Gabi, tem gente que faz uso de maconha sem nunca ter tido nenhum problema para demandar a busca por um tratamento. Como é que uma pessoa que está tentando se tratar, vamos dizer assim, diminuir o uso, parar de usar, como que ela vai dar conta numa casa em que todo mundo bebe e tudo bem. Tem gente que, inclusive, não só a maconha, mas inclusive que cheira esporadicamente, faz uso de cocaína esporadicamente. Poxa, mas meu sobrinho consegue. Nós já tivemos casos aqui que pai, todo mundo, a família inteira usava. Aí tinha um coitado aqui, para se tratar. O pai tinha já sessenta e poucos anos. Fumou a vida inteira. Todos os outros filhos, mas um coitado foi o eleito. Esse era problemático. Tinha que vir se tratar. Mas e os outros? Então, muito delicado. Pesquisadora - Depende de como indivíduo se enxerga mesmo.

E7 - Sim. Sim. 
Pesquisadora - E quando você falou inicialmente dos usuários de crack você disse dessa coisa da individualidade, de entender qual a situação que a pessoa vivencia, eu percebo no seu discurso uma característica muito mais de cuidado do que de repressão. E aí vou te perguntar. Qual você acredita que seja a abordagem mais adequada para esse primeiro contato com o indivíduo usuário de crack? Uma abordagem de acolhimento ou uma abordagem repressora.

E7 - De acolhimento, com certeza.

Pesquisadora - Por quê?

E7 - Porque primeiro, assim, pela minha experiência, as pessoas que chegam aqui, só o fato de eles estarem num espaço e eu estou falando de um espaço, de um micro, de nada, diante do que é hoje a população que usa crack na rua, inclusive. Ter alguém para ouvi-las, sabe? É muito importante para eles. Estar num espaço que todo mundo está ouvindo, então, tem os que não são de crack, são de outras, mas está todo mundo ouvindo a história dele. Todo mundo se sentindo solidário com ele no sentido de acolher: "Vem, fica aqui com a gente. Vem para cá. A gente também tem problema". Não uso isso, eles costumam dizer: "Eu não uso essas coisas". Mas eu sei o que é porque tem as outras questões que é falta totalmente de sentido de viver, é a solidão, é a angustia, a depressão.

Pesquisadora - E aí eles conseguem se identificar?

E7 - Eles acabam se identificando. Eu acho que porque lá no mundo do uso, Gabi, eles são todos "loucões", como eles dizem. Então, não tem isso. é tudo nada. Não existe olhar, não existe toque, não existe nada. Tudo que acontecer lá, na maioria das vezes vai trazer danos, porque não tem sentido. É tudo muito louco. É o ficar louco, como eles também gostam de dizer. Aqui é diferente. Um falando, contando a história dele com álcool, outro contando que perdeu isso, que perdeu aquilo, então, aí sim, ele começa a se sentir de novo uma pessoa: “Opa, tem outras coisas também. Não é só aquela fantasia, aquela loucura da droga. Aquilo está ali no canto, mas aquilo não é tudo. Tem outras coisas. Existem pessoas que são capazes de conversar com a gente, de pegar na mão da gente, porque eles têm essa coisa. Eles viraram literalmente 'lixos'. Ninguém chega perto. Passa perto, puxa a bolsa como se todos fossem roubar. Não é assim que funciona. Eu vejo muito essa dificuldade do contato, num primeiro momento até de falar, porque eles chegam com muito medo. Então: "O que eu vou falar? Eu posso falar tudo? Eu não posso?" Então, um lugar em que eles consigam se sentir à vontade, que eles possam falar de verdade, do que eles estão sentindo de fato, inclusive do prazer, 
porque também, às vezes, fica muito na coisa: "É ruim, é mau”. Eles sabem melhor do que a gente que os malefícios daquele uso, porque eles sentem na pele.

Pesquisadora - Mas eles sabem que é bom também.

E7 - Mas também bom por conta da fuga. Da fuga no momento que não dou conta disso, o que é isso que está acontecendo na minha frente, então vou lá. Fico lá. Entro numa brisa. Só vou pensar naquilo um tempo depois de novo, quando eu sair daquele baque todo. Então, é muito importante acolhê-los como pessoas. Não só como coisa. Reprimir, eu, de verdade, não conheço, não sei, não acredito nessa coisa de reprimir, sabe? Para nada. Não é só em questão de uso, porque a proibição, para mim é uma questão. Eu não sei onde que é proibido. Eu não faço uso de nada, mas sou obrigada a estar andando na rua e estar inalando fumaça de maconha. E é proibido. Aonde? Então fica uns debates, umas discussões, umas coisas sem pé nem cabeça que não leva a lugar nenhum. Não resolve problema nenhum. As pessoas estão se drogando cada vez mais.

Pesquisadora - E por que você acha que a proibição não adianta para nada? Para nenhuma questão?

E7 - Porque o ser humano tem essa coisa da 'curiosidade' de experimentar. Nós somos movidos por isso. Então, não adianta... E ainda tem aquela coisa dos ditados antigos, não é? Quanto mais proibido, melhor a coisa. Se a gente pensar lá antigamente, na época da minha avó, era coisa do namorar escondido. Era muito bacana e as pessoas namoravam tempos e tempos escondidos, porque era proibido, não podia, não sei o que, e era tudo certo, tudo bonitinho. Porque é uma outra relação que eles criaram, inclusive, nessa coisa de se proteger, de se cuidar para não aparecer, para ninguém pegar. No caso de um namoro, não engravidar e aí vai ser descoberta. Mas tem uma relação outra de cumplicidade. Cria-se uma outra relação. E essa curiosidade do ser humano. Ele sempre vai estar querendo experimentar. A gente está vendo isso. Então, cada vez que aparece uma droga diferente, o povo está lá querendo. Os usuários estão... É engraçado que fica tão fora, como se uma não fizesse mais sentido. Mas não sei se aquela droga de escolha não está dando mais conta, mas a curiosidade do que é que eu vou encontrar na outra que está chegando, que está aparecendo.

Pesquisadora - Você falou um pouco também do medo de chegar aqui e falar, até onde eu posso falar, até onde eu posso chegar e aí me veio uma coisa na cabeça. Será que uma ação primeira que tenha repressão como mote não pode afastar esse indivíduo? Não pode dar mais medo e aí de repente eu demoro mais a conseguir me aproximar do tratamento?

E7 - Eu acho que sim. Porque o acontece? Se você pegar... 
Pesquisadora - Ou, eventualmente, aí vou fazer outro lado, mas eventualmente, poderia incitar uma reflexão no sentido de: "Não quero mais passar por isso e vou buscar". E7 - Eu não sei viu? Esse outro lado. Cada indivíduo é um. Tem gente que vai: "Não quero mais passar por isso, vou buscar”. Mas tem gente que não. Que aquilo ainda é muito abusivo. É muito agressivo. Ele se sente lesado no seu direito, então, ele vai continuar fazendo.

Pesquisadora - Você acha que os usuários se sentem lesados? Você já ouviu... Dos relatos que você já deve ter ouvido da relação deles com a polícia ou com a Justiça, os relatos são de uma relação cidadã ou de um abuso?

E7 - De abuso sempre. De abuso. E eles ficam muito indignados, porque no mundo deles, eles conhecem quem usa. Então, eles sabem que muitos daqueles policiais que estão ali abusando do poder, também estão sob o efeito de algum tipo de... Que seja álcool, o que for, de entorpecente, outra coisa. Então, eles se sentem muito mal com isso, com esse abuso. Quem é o cara? Sabe aquela história do espelho? Então, o pai quer fazer tudo bonitinho para o filho seguir o modelo. Só que daí ele faz umas coisinhas tortas por trás, tentando esconder do filho. Acaba dando esse choque. Eles se sentem abusados totalmente, até porque a gente sabe de relatos, inclusive, da pessoa não estar nem com nada. Não sei o que. É uma pena. Não são todos, mas a gente vive hoje num mundo muito corrupto. Então, o dinheiro vai falar sempre mais alto. Infelizmente, acho que por conta desse capitalismo, tudo isso, se vive em função disso, não é? “Ah, mas coitado. O policial ganha pouco". Ele escolheu aquela profissão. Existe uma diferença entre as pessoas que fazem por amor e as pessoas que fazem por outros motivos, sejam eles quais forem, inclusive, eu não sei, eu sempre olho para a polícia, eu vejo casos acontecendo que eu fico pensando: "Meu Deus. Que tipo de seleção que essa pessoa passou?" Porque um policial que joga álcool numa pessoa e ateia fogo e vai dizer que foi acidente, ele se machuca e mata uma pessoa queimada. Não sei. É isso que é Justiça? É isso que é lei?

Pesquisadora - E aí de repente, você acha que seria melhor uma política de drogas em que a gente mantivesse viabilizado esse primeiro contato polícia/usuário? Que o primeiro contato fosse por um profissional distinto?

E7 - Eu acho que um profissional distinto faria toda a diferença. Distinto e bem capacitado. Porque também não adianta você ser profissional da área da saúde, fazer um serviço e você estar impregnado de tudo, não poder olhar para esse outro como um ser humano. Não vai adiantar nada. Como um igual. Que bom se eu não tenho nenhum problema com isso, mas eu estou livre de ter com meus filhos ou com alguém muito próximo. Olhar como uma 
pessoa. Um igual. Pensar nessa fragilidade do ser humano, nesses altos e baixos da vida, tudo isso. O profissional tem que ter isso. Eu costumo dizer, Gabi, que quando a gente vai trabalhar com dependente químico, a gente tem que se despir. Sabe? Acho que muito mais saudável do que ficar me instrumentalizando, me enchendo de teoria. Não é isso que faz a diferença nesse contato com eles. Eu vejo pelos que chegam. Toda semana chega gente nova por conta da triagem que acontece às quartas. Você tem que se por ali junto com eles. Não adianta ficar ali no alto: “Ah, eu sou a psicóloga”. Não vai dar liga. Às vezes ele não fíca. Às vezes ele não volta nunca mais. Somos seres humanos. Estamos aqui para trocar. Esse espaço é para a gente estar trocando experiências. Eu estou aqui para mediar, para direcionar junto com vocês, mas não sou melhor do que ninguém. E costumo sempre dizer: "Não é porque eu não uso, gente, que eu sou melhor do que vocês”. Porque eu não uso álcool. Não uso outras drogas, mas sou um ser humano de carne e osso igual a vocês, tenho problemas tanto quantos e é isso. Não sou melhor do que ninguém por isso. Não falo isso para me gabar: "Ah nunca usei". Gosto até de contar para eles por que nunca virei tabagista na adolescente. Porque eu tinha dó de comprar o cigarro e tinha vergonha de pedir. Porque senão eu era uma tabagista hoje. Com 13 anos. Não teria parado nunca mais. E aí eles falam: "Nossa, mas que legal”. Eles pensam. Momentos muito difícil de dizer não. Que as coisas... A curiosidade que move o ser humano. Então, a relação tem que ser muito próxima. Tem que ser de gente para com gente. Não é de máquina, não é avental branco. Não é pose, Gabi. É gente. É gente que corre sangue na veia porque senão não adianta. Fica distanciado.

Pesquisadora - Eles precisam se sentir mais iguais.

E7 - Eles precisam.

Pesquisadora - E aí eu te pergunto. Você acredita nessa coerência dessa política que privilegia a reinserção social e tratamento, mas que mantém o usuário no rol dos criminosos? E7 - Não, não é? Porque inclusão. Está, tudo isso, mas o cara está ali carimbado, estigmatizado o tempo todo. Sempre visto como: “Ah, aquele é ex-drogado. Ele é exdrogado. Ele está por aqui porque...”. É tirando tudo isso, gente. É tratar como outro, como igual, como pessoa. Isso é que faz a diferença. A diferença é a gente olhar para o outro como ser humano, independente, porque se a gente vai parar para ver cada pessoa, quanto mais contato a gente faz com pessoa, mais a gente se enriquece de conhecimento. Muitas vezes a gente fala: "Nossa, eu achava que tinha problema. Olha a história dessa pessoa. Olha a história da outra. E eu aqui reclamando da vida". É o que eu disse. O buraco é muito mais embaixo, não é? 
Pesquisadora - Obrigada. Acabou?

E7 - Acabou. 


\section{ENTREVISTADO: E8}

Arquivo de Áudio:130807_003

Tempo: 00:27:32

Pesquisadora - Fala primeiro seu nome completo.

$\mathbf{E 8}-(\ldots)$

Pesquisadora - Qual sua especialidade?

E8 - Psicólogo.

Pesquisadora - E você trabalha com usuários de drogas há quanto tempo?

E8 - Tratamento há uns dois anos e nove meses.

Pesquisadora - $\mathrm{O}$ tempo todo aqui no PROAD ou você trabalha com usuários em outros lugares também?

E8 - Então, no PROAD, principalmente, eu trabalho com outros enfoques do uso de drogas. Prevenção, como pesquisador discutindo política, mas com tratamento dependentes é no consultório e no PROAD.

Pesquisadora - Até para eu te explicar um pouco, no começo, a mostra do meu trabalho é restrita a usuários de crack. Então, as perguntas, se você puder pensar... Obviamente, é interessante discutir o teu conhecimento no geral, em relação a todos os usuários, mas se a gente, de vez em quando, puder pensar especificamente a usuário de crack é interessante também.

E8 - Usuário de crack...

Pesquisadora - Então.

E8 - Em situação de rua?

Pesquisadora - Não necessariamente. Usuário de crack pode até ser um usuário que não tenha o crack como droga de eleição. Eu restringi a amostra aqui do PROAD para os usuários que relataram uso de crack nos 12 meses anteriores à triagem. Então tem muitas perguntas que pegam o uso de drogas como no geral, mas de vez em quando eu faço algumas mais específicas. Pela sua experiência de atuação, você acha que tem alguns fatores que podem ser considerados como relevantes para a busca pelo tratamento? Os usuários relatam situações semelhantes que ensejaram essa procura pelo tratamento? 
E8 - Ah, eu acho que eu não consigo ver razões muito claras e dadas a priori. Acho que se fosse para dar uma resposta geral, eu até fugiria um pouco da dependência do crack. Eu percebo que as pessoas que normalmente vão procurar tratamento, elas acabam sendo uma peça da sociedade que não funciona. Elas vazam do esperado socialmente. Aí está incluído um ajuste social nas relações interpessoais, está incluso também a própria funcionalidade de não conseguir trabalhar. De alguma maneira, me parece que as pessoas que são consideradas pessoas que têm problemas com drogas, são pessoas que em algum aspecto da vida não estão se adequando ao que a sociedade espera delas.

Pesquisadora - Mas em algum aspecto da vida, eu posso citar o uso da droga como causa direta ou é um fator decorrente. Por exemplo, eu uso a droga e aí tem problemas no trabalho. Então essa decorrência do uso que me faz sentir desajustado. Ou só por usar eu já me sinto desajustado?

\section{[Uma terceira pessoa interrompe a entrevista]}

Pesquisadora - Eu vou pegar a chave rapidinho. Desculpa.

E8 - Pode repetir só para eu ter...

Pesquisadora - Posso. O que você falou de alguma situação de eu me sentir desajustado em relação à sociedade. E aí, o que eu quero saber é: Se essa visão do desajuste decorre do uso da substância ou decorre de alguma situação relacionada com o uso. Entendeu?

E8 - Eu acho que é muito perigoso pensar que o uso de uma substância, por si só, significa alguma coisa. Acho que sempre que a gente pensa o uso de drogas no aspecto amplo, está inserido no contexto todo de vida. A gente pode até abstrair e tentar achar uma causalidade entre o uso e algum problema social, só que, com certeza, a gente não está enxergando o fenômeno como um todo, porque entre tantas escolhas que nós somos convocados no dia a dia, uma escolha possível é de usar droga ou não e de que modo usar droga. Quando a gente pensa simplesmente que a droga pode causar um desajuste, normalmente a gente está ignorando o resto todo da vida. Até porque, às vezes, dá para as pessoas tocarem a vida cheias de problemas e aí quando falam do uso de drogas, socialmente é entendido como 'o problema'. É um problema... Tipo, tenho um problema com meu relacionamento, tenho um problema com meu trabalho e para dar conta dessa vida assim, que talvez não me faça sentido, eu posso usar drogas do modo dependente, de um modo bem específico, um modo dependente. E aí, ao invés de ter um monte de problema. Ao invés de ter um monte de problemas, eu tenho um só. O uso de drogas. Então, quando eu penso em algo causal estrito do uso, penso que a gente pode estar vendo o fenômeno de um jeito muito simplista. 
Pesquisadora - E aí você disse essa história da sociedade ver o uso de drogas como um único problema, eu te pergunto: Você acha que o usuário de drogas se sente diferente do restante das pessoas por ser usuário?

E8 - Então, eu acho que tem... Uma questão que eu queria responder antes dessa. Antes de o usuário se sentir diferente, usualmente a gente pensa que o uso de drogas a gente está falando das drogas ilícitas e não das drogas lícitas.

Pesquisadora - Eu ia chegar...

E8 - É. E normalmente o uso é drogas ilícitas. E as drogas ilícitas são... Qualquer uso é patológico, qualquer uso é problemático. O uso das drogas lícitas, normalmente, às vezes, é menos perigoso, menos danoso. Só que há um mito aí porque o que são drogas? A partir do momento que a gente tem uma compreensão de que a gente está falando de drogas psicoativas, então, a gente está falando de substâncias que ao serem utilizadas vão alterar o funcionamento do sistema nervoso central. É engraçado que nessa conta, não aparece que café é droga. Não aparece que diversos tipos de medicamentos psiquiátricos são drogas. Não aparece que o álcool é a droga com maior número de dependentes. Oitenta por cento da população adulta brasileira vai ter usado álcool. Isso tudo é ignorado. Ou seja, pensa-se que quando tem uma divisão no critério entre licitude e ilicitude no uso de substâncias, a gente está pensando num panorama de saúde. Só que, minimamente, se a gente faz uma revisão histórica, a gente vê que a própria história da proibição, que começa com a tentativa americana de normatização de algumas drogas, ela não parte de pressupostos de saúde. Tem vários interesses, como o começo da política. Em 1909 foi feito o primeiro ato de regulação das drogas nos Estados Unidos. E aí, logo depois, eles tinham grande interesse internacionalmente de se aproximar da política chinesa. Porque eles tinham interesses comerciais com a China. Possíveis, não é? E eles tentaram proibir o ópio. Tentaram fortalecer a política de proibição do ópio, já que a China defendia uma política de proibição do ópio e tinha uma questão de perseguição de minorias de chineses no território americano que comandava os sindicatos americanos. Então, quando a gente pensa a questão, a gente não pode se enganar que licitude e ilicitude tem a ver com saúde. A gente tem que tentar enxergar de um modo amplo. Então, minimamente, uma revisão histórica do uso de drogas, a sociedade não mudou. Da sua existência. E uma revisão histórica do "proibicionismo" tem que ser vista para a gente poder pensar seriamente nesse assunto. Aí a pergunta era se...

Pesquisadora - Se os usuários se sentem diferentes do resto da população por serem usuários. 
E8 - Isso. Eu tenho obrigação de falar. Quando a gente pensa na política de drogas, a gente pensa que a política nacional brasileira atual é muito influenciada por uma lógica "proibicionista". Uma lógica "proibicionista" que veio dos acordos firmados na ONU desde 61 e que o Brasil é signatário e tem que cumprir. Simples assim. E quando eu penso nisso, eu penso também que toda vez, historicamente, que as drogas foram proibidas, a gente vê claramente na lei seca americana e na circunstância atual, para não dizer que estamos longe, a circunstância atual de drogas no Brasil. existem substâncias que sempre existiram na sociedade. Tudo bem que a gente hoje vive numa sociedade que o consumo tem um viés bem específico no modo de vida das pessoas. Tudo é consumo. Droga, que já teve um viés ritualístico em outras sociedades, na nossa sociedade tem um viés de consumo e quase num consumo de prazer. E a proibição do uso, o que sempre gerou? Nunca gerou diminuição do consumo. A proibição do uso sempre gerou uma rede marginal de consumo de drogas. Uma rede marginal de consumo de drogas que têm uma organização específica, que está à margem da lei gerindo isso, que tem o usuário que muitas vezes é tomado como um marginal, já que ele está cometendo um ato minimamente ilícito. E que aí a gente começa a conversar um pouco o que é o usuário de drogas na realidade brasileira.

Pesquisadora - É aí que eu ia te perguntar. Você acha que essa pecha de marginal que permanece, tendo em vista que o porte para uso pessoal permanece sendo conduta criminosa, como primeiro contato Estado/indivíduo, ela viabiliza o tratamento ou ela prejudica essa aproximação?

E8 - Está. Só queria responder a uma outra pergunta antes dessa, assim, porque eu acho que é importante falar sobre isso. Deixa lembrar o que eu estava falando.

Pesquisadora - Você estava falando do papel do usuário nessa rede paralela. Nesse mercado paralelo que é gerado pela proibição.

E8 - Isso. E a sua pergunta foi...

Pesquisadora - A minha pergunta é: Porque, na verdade, a gente tem uma situação de proibição que vai da proibição da substância em si, que aí inviabiliza o comércio da substância, a produção dessa substância, mas a gente permanece tendo uma previsão de proibição do porte para consumo pessoa. Então, eu usuário, desde que portando substância ainda sou criminoso. Apesar de eu ter a aplicação de medidas alternativas à prisão. Como tem a imposição de medidas alternativas à prisão,que são medidas em tese educativas, em tese de reinserção social, eu questiono um pouco a respeito desse rótulo. Por permanecer criminoso, por permanecer à margem da norma, marginal, esse estigma, e aí sua opinião 
como profissional de saúde, prejudicaria o tratamento, a reinserção do indivíduo à sociedade? E numa postura de atenção?

E8 - Com certeza sim. Com certeza, esse estigma prejudica. Eu sinto isso na clínica cotidianamente. Acho que antes eu tenho que dizer que o "proibicionismo" tem algumas peças chave. Então, voltando, primeiro aspecto. As drogas são drogas ilícitas. Lícitas não são drogas, claro. Todo uso de droga ilícita é patológico. O uso de drogas lícitas é menos danoso, mas todo uso de droga ilícita é patológico.

Terceiro. Devemos combater o uso de drogas ilícitas.

Quatro. Devemos chegar num mundo livre de drogas.

Quando a gente pensa que todo uso, qualquer tipo de uso de droga é patológica, de droga ilícita, não é? Já ignora-se, então, as drogas lícitas ainda que o maior número de dependentes é do álcool. Mas quando você pensa que qualquer uso é patológico, aí você não diferencia nada no meio do balaio. Tem muita coisa junta. $\mathrm{O}$ usuário, eles têm vários modos de uso, tipos de uso. Uma classificação possível seria: O usuário pode ter um uso experimental, primeiro contato com a droga, um uso ocasional, que ele já conhece a droga e usa vez sim, vez não, sem seguir uma frequência. Um uso habitual, que aí alguma frequência já é seguida. Depois a gente fala de um uso bem restrito que é a dependência de drogas, onde há necessidade de uso para satisfazer um desprazer gerado pela ausência da droga. E nem entra em dependência funcional ou não. Mas veja, dentro de casa uso desses, dá para a gente ter ou o uso controlado ou o uso sem controle, um uso sem medida, um uso abusivo. Então, dá para experimentar abusivo controlado, dá para experimentar o uso ocasional, abusivo controlado, dá para ter um uso habitual, abusivo ou controlado. Dá para ter um uso dependente abusivo ou controlado. Quando a gente simplesmente pensa: "Ah só porque as drogas são ilícitas". O usuário que faz uso dessas drogas é um criminoso, em alguma medida, acho que a gente está ignorando que usuário é esse. Aliás, quando nós tratamos um usuário de drogas com uma questão de Justiça e não uma questão de saúde, acho que já está colocando um lugar para esse usuário. Esse usuário é um cidadão à margem. É um cidadão que infringe as regas do jogo. Então, se eu tiver um uso controlado de maconha e eu nunca fiz um uso de risco que envolva maconha, eu sou um infrator. No consultório, a gente ouve... Discutindo casos, a gente houve relatos até de uso de crack controlado, que o paciente vai, usa no fim de semana, durante a semana ele trabalha. É simples? Não. A maior parte das pessoas que usarem crack vão conseguir fazer esse uso? Talvez não. Só que é possível, por uma questão de licitude e ilicitude, que tem a ver com a política internacional que não primou 
pela saúde, esse usuário é tido como um criminoso, sendo que ele pode fazer um uso que gere muito menos risco do que um indivíduo usa uma droga lícita como o álcool e dirige e mata alguém.

Pesquisadora - E os relatos dos pacientes sobre esse contato com polícia e Justiça são no sentido mais de compreensão e acolhimento ou no sentido mais de agressão e repressão? E8 - Então, atualmente não tem uma clareza de quantos por cento, se eu vejo mais de um lado ou mais do outro. É uma deficiência de compreensão minha. Só que eu vejo o trabalho de outras pessoas. Eu discuto drogas, eu tenho uns amigos que trabalham com o projeto Quixote. Eles falam como que essa população é uma população que, normalmente, está à margem. Acho que não precisa nem ir muito longe para ver isso. Outro dia, eu estava vendo Profissão Repórter e aí tinha um cara que tinha uma dependência de uma droga. E aí, o que acontecia? Foi uma equipe até a casa do cara e queriam convencer ele para ele ir se tratar. Ele não queria se tratar. Ele falou: "Olha, conheci uma menina lá. Eu vou dormir hoje com a menina". E não vou. Aí o que os profissionais fizeram? Eles falaram assim: "Está bom, mas calma aí. Vou dar um remédio por causa do joelho machucado". Chumbaram o cara e levaram ele internado. Meu, como que dá para falar se uma equipe de saúde negligencia totalmente os direitos de uma pessoa e não expõe claramente o que está acontecendo, passa por cima de toda sua possibilidade de decisão e interna o cara à força, acho que normalmente é dessa visão social que a gente está falando do dependente de crack.

Pesquisadora - Eles não têm querer.

E8 - Eles não precisam ter seus direitos respeitados. Outro dia, numa conversa, eu vi uma amiga comentando que leu um artigo de um cara que estava fazendo uma leitura que o dependente de drogas é o novo louco. É. O dependente de drogas é o novo louco. Se ainda hoje, em termos de saúde mental, a gente se depara com algumas discussões de alguns hospitais psiquiátricos que a partir da humanização dos serviços de saúde, não foi bem ouvida quando eles propuseram a [Ininteligível] o serviço, imagina com usuários de drogas, onde na esfera programática, o Governo Federal investe em comunidades terapêuticas. Comunidades terapêuticas que muitas vezes têm um viés religioso ligado à sua cultura, sendo que a gente está falando de financiamento público de saúde, que a rigor deveriam seguir as diretrizes do SUS num serviço humanizado e também não ligado à instituições religiosas. A partir do momento em que o Governo Federal implementa uma política desse porte, ignorando as próprias diretrizes do SUS e a assistência dada aos usuários, aí acho que o senso está claro. Que o usuário de drogas não é um indivíduo que mereça um... 
Pesquisadora - A atenção padrão.

E8 - É. Ele pode ser negligenciado, ele pode ter seus direitos totalmente ignorados. E acho que normalmente é uma população de extrema vulnerabilidade individual, social e programática, que a gente está falando, quando a gente está falando de dependentes de crack. É porque o cara da classe média que usa crack, normalmente ele tem um uso mais ajustado possível. Tem coisas a perder. Que está numa situação de extrema vulnerabilidade, talvez o uso seja uma solução de vida.

Pesquisadora - E você acha que essa política criminal que mantém o usuário na condição de criminoso reforça isso?

E8 - Sim. Sim. Acho que quando a gente fala de um quadro de dependência de drogas, a gente está falando que talvez seja difícil do próprio indivíduo se apropriar das escolhas que ele faz, inclusive o uso de drogas. Assim como sexualidade, autocuidado e uma dificuldade de conseguir se apropriar do que ele está passando e tomar uma decisão que visualiza um futuro que ele queira. Muitas vezes quando a gente pensa na compulsão do uso, a vida é meio repetida no uso. Nada é retomado, pensado e decidido num uso tão intenso quanto a gente vê em alguns casos de dependência de drogas, de crack nos grandes centros urbanos. Mas é isso. Tipo, ai meu Deus. Eu dormi pouco. Estou com problema de memória. Eu estava falando do que mesmo?

Pesquisadora - Você estava falando que no uso de drogas, geralmente as situações são repetidas...

E8 - Ah lembrei. Isso. E aí fica difícil de conseguir ajudar esse indivíduo a reaver a própria vida e suas decisões. Quando a gente pensa num cenário em que o lugar do indivíduo na sociedade não é preservado porque o tratamento funciona numa lógica que não prima por uma devolução de autonomia e sim por um ajuste social, retomando minha primeira fala, aí é bem difícil de lidar com o tratamento. Eu penso assim, que o mundo em que vivemos hoje é um mundo técnico. É um mundo do controle que a gente tenta garantir o conhecimento técnico para dar conta dos desdobramentos da vida. Dentro disso, dá para a gente discutir por que o uso de drogas ilícitas é algo patológico. Porque é “desviante”, não é? Num mundo onde tudo é passível de mensuração e controle, que é o mundo científico. Aquele que é desviante é uma ameaça. Nisso eu até penso. O próprio tratamento... Porque tem uma frase muito bonita do Dartiu na porta que é: "O contrário da dependência não é abstinência e, sim, a liberdade". Está. Mas se a gente trata dependência com liberdade não é isso que acontece quando a gente pensa em serviços, nesses últimos desdobramentos do tratamento de 
dependentes de crack. Por quê? Você pega e tenta desenvolver uma técnica para dar conta do tratamento. Então, a técnica atual é internação. Internação que tem como começo e fim, muitas vezes, a política inteira. Não como internação pontual que tem a ver com o período de desintoxicação para ser acompanhado no hospital/dia, com serviço ambulatorial e com psicoterapia, acompanhamento médico e qualquer outro profissional de saúde que seja necessário. Não. A gente pensa em comunidade terapêutica. É a terapia da enxada. A partir de uma noção de que o usuário de drogas é o indivíduo que não tem, não consegue preservar o valor das coisas, o autocuidado e, a partir do trabalho, normalmente braçal, tem que dar conta de reaver o valor do trabalho, o valor da vida e, assim, se livrar, não é?

Pesquisadora - Numa mentalidade até cristã, não é?

E8 - E tem uma moral por trás. Não é por pouco. Não vamos ignorar que o papel da igreja hoje na sociedade é: “Ah, mas pelo menos eles tratam drogados". É, mas tratam como o drogado? No mundo técnico, que funciona, a solução é: Você pega o indivíduo que faz uso de crack, aproveita para ele [ininteligível]. Você controla o uso de droga dele, ou seja, interna. Normalmente, essas instituições têm um viés religioso e o que você faz? Junto com o controle do uso de drogas dele, que você não permite que a droga chegue, você vai doutrinando ele com uma religião. Você tira o usuário, se tudo der certo, o que normalmente não dá, mas você tira o usuário de um uso descontrolado de drogas, controla primeiro o uso. Depois o que você faz? Você controla ele a partir da religião. Eu não estou negando que seja possível a pessoa se apropriar dar religião que ela tenha. Só estou dizendo que normalmente, o serviço é: “Ah, Deus não vai deixar eu usar”. Ou: "Vamos lá. Deus vai me ajudar”. São chavões prontos que vão ajudando a resolver a vida, mas que não necessariamente aproprie o indivíduo da vida que ele está realmente escolhendo. E aí depois você devolve ele na sociedade. Se tudo der certo - de novo, coisa que quase nunca acontece - o que vai acontecer no final? No final você vai ter um indivíduo que antes era desajustado, improdutivo. Você, na melhor das hipóteses, devolver um indivíduo possivelmente alienado, mas produtivo. Uma "peça", uma "engrenagem". Só que eu não acho que o modo que nós devemos lidar com as pessoas é o mesmo modo como a gente lida com qualquer outro item que a gente vai usar como instrumento na vida. Então, uma pessoa não é um ente que serve para tratar na sociedade, gerar riqueza. A gente está falando daquele que pode escolher como viver. Que a cada instante decide a vida que quer ter. Então, se não é por esse modo de entender a questão do uso de drogas, acho que, no fim das contas, a gente é só "mecânico de gente". E quando 
a gente está mal, a gente não vai no mecânico. Acho que tem algo mais a ser olhado e que é totalmente ignorado nas políticas do jeito que estão sendo implementadas.

Pesquisadora - É isso aí.

E8 - Boa. 


\section{ENTREVISTADO: E9}

Arquivo de Áudio:130807_003

Tempo: 00:09:17

Pesquisadora - Qual que é seu nome completo?

E9 - (...)

Pesquisadora - E a sua especialidade?

E9 - Eu sou psicóloga com especialidade em Neuropsicologia.

Pesquisadora - Você trabalha com usuários de drogas há quanto tempo?

E9 - Há dois anos e meio.

Pesquisadora - Aqui no PROAD?

E9 - Isso.

Pesquisadora - E você faz o que aqui no PROAD?

E9 - Aqui no PROAD eu faço grupos de dependência não química. Grupo de acolhimento de dependência não química. Faço atendimento psicológico individual, psicoterapia e também trabalho com avaliação neuropsicológica.

Pesquisadora - Está. Você acha, pela experiência, que você tem com usuários de drogas e aí eu peço para você pensar um pouco mais nos usuários de crack. Pode pensar no todo, mas como minha amostra se restringe a eles, é interessante que tenha um pensamento um pouquinho mais direcionado. Existem alguns fatores que você pode considerar como importantes para a busca pelo tratamento? Alguma situação que eles relatam com frequência? Eu vim procurar tratamento por isso.

E9 - Geralmente, do que eu vejo, o usuário busca tratamento quando ele tem uma perda quase que total. Ele tem uma perda social, ele tem uma perda física, no sentido de uma perda da saúde, tanto a saúde mental quanto as condições... Ele fica muito limitado. Então, quando na verdade o usuário busca ajuda, o que, na maioria das vezes não é ele quem busca, de alguma maneira eles buscam quando chegam numa situação limite. Limite de não tenho mais para onde correr. Então, o tratamento acaba sendo uma forma de tentar levantar aí nesse processo de uso de drogas.

Pesquisadora - E eles costumam trazer algum problema com a polícia, quando decidem iniciar o tratamento? Relatam essa situação? 
E9 - Bom, comigo, especificamente, na experiência que eu tenho no PROAD não. Nunca apareceu. Apareceu sim na dependência não química, pacientes que foram presos por pedofilia e que o tratamento faz parte, eles já vêm orientados de que o tratamento seria muito bom para eles. Mas da dependência química, especificamente, aqui no PROAD nunca atendi a nenhum paciente que falasse uma questão policial, assim.

Pesquisadora - Você acha que os pacientes, agora no geral, usuário de qualquer tipo de droga, se sentem diferentes do resto da população por serem usuários?

E9 - Diferente em qual sentido?

Pesquisadora - Eles carregam alguma vergonha?

E9 - Eles carregam o estigma. Sim. Esse estigma em relação à dependência química e, principalmente, em relação à dependência não química, que é muito mais... Não tem a química, não tem o objeto do desejo, mas eles carregam o estigma. O alcoolista vai ser sempre um alcoolista, um viciado em crack vai ser sempre um ex-viciado. Então, esse estigma da droga acompanha a dependência química e o usuário.

Pesquisadora - E você acha que tem uma diferença entre as drogas lícitas e as ilícitas? E9 - Sim. Existe. Existe uma diferença, enfim, uma diferença social mesmo. Até mesmo dentro dos grupos, às vezes, você vê essa diferenciação entre os pacientes. Nos grupos de acolhimento, às vezes, uma pessoa que é alcoolista, ela julga, ou quem é dependente de múltiplas drogas, julga: “Ah, mas teu problema é só o álcool”. Então, existe essa diferenciação sim.

Pesquisadora - E aí dentro dessa propaganda do governo no sentido do crack como o pior dos males pode reforçar essa situação do estigma dos usuários?

E9 - Sim. De alguma forma sim.

Pesquisadora - E você acha que esse reforço é positivo ou negativo para que eles procurem se tratar?

E9 - Para o tratamento...

Pesquisadora - Ou não tem nenhuma influência?

E9 - Não. Eu acredito que esses pacientes que o governo busca oferecer o tratamento, eles já não tem essa capacidade de volição, uma capacidade de querer e de entender a busca do tratamento. Uma coisa é quando você pensa num dependente de crack que vive numa situação de risco, uma situação precária e tudo mais, mas que ele ainda tem a consciência que se ele buscar um tratamento, pode existir uma saída. Outra coisa é o usuário que já vive naquela Cracolândia, já sabe onde ele consegue alimentação, onde ele consegue banho. O 
que ele vai ter que fazer para conseguir a droga. Então, assim, de alguma maneira, ele vive aquela situação. Então, sinceramente, essa oferta de tratamento do dependente do crack me deixa muito indecisa. Não sei até que ponto tem resultado. Assim no sentido...

Pesquisadora - E aí pensando num primeiro contato com esse usuário, você acha que um primeiro contato repressivo funciona ou um primeiro contato de acolhimento funcionaria melhor?

E9 - De acolhimento.

Pesquisadora - E aí por que não o repressivo? Por que não dar um susto?

E9 - Porque daí talvez eu entraria com questões psicológicas, não é?

Pesquisadora - Pode entrar.

E9 - Daí entraria em questões mesmo da conscientização, do quanto ele tem claro, do quanto ele já foi reprimido, ele já foi excluído. Uma pessoa que está numa condição de precariedade, morando nas ruas, fazendo uso do crack, que tem a diminuição da capacidade dele de volição, tem um efeito de uma droga química. Então ele tem uma questão química, tem essa dependência. Reprimir de uma condição de vida que talvez tenha levado ele a esse uso. Então, acho que reprimir não seria o caso. Tanto a gente sabe, que a internação compulsória não obteve um resultado, enfim, eficaz. Não foi uma intervenção eficaz. A intervenção compulsória.

Pesquisadora - E algum, não sei se você já teve algum paciente que tenha relatado alguma experiência com polícia para saber se eles relatam uma experiência de aconselhamento, mais de colaboração ou algo mais violento e agressivo?

E9 - Então, na verdade, dos poucos que eu ouvi falar, porque foram bem poucos aqui no PROAD, no grupo mesmo foi uma atitude um pouco mais ofensiva, mais punitiva, que gera certo receio. Gera um certo medo. Não posso confiar em polícia. Mais fácil confiar no traficante, do que... Mais fácil confiar no tráfico do que na polícia.

Pesquisadora - É. Então, e aí de repente esse medo e essa sensação de desconfiança em relação ao formal, ao Estado, você acha que pode ter um efeito perverso no sentido de julgar aquele indivíduo mais para a margem do que ele já está?

E9 - Sim. Acredito que sim, até porque talvez a gente volte um pouco nessa intervenção um pouco mais de repressão, não é? Eu vejo essa punição que nós temos no nosso sistema que não é por isso que ele deixa de roubar para usar droga, não é por isso que ele deixa de traficar para ter um dinheiro extra, o que for. Então, essa medida, por mais que seja repressora e não acolhedora, também não faz com que o usuário deixe de fazer as coisas... Enfim, ele tem 
como objetivo. Preciso do dinheiro. Então vou roubar. Preciso do dinheiro para droga. Preciso traficar. Mantém o comportamento. Então é ineficaz. No meu ponto é ineficaz.

Pesquisadora - Se você fosse estabelecer uma política, você estabeleceria uma política de contato mais de tratamento e menos policialesco?

E9 - Sim. Sim. Acho que sem tratamento você não recupera. Isso aí a gente fala de uma questão social, que envolve muito o uso de droga, se você não inserir esse usuário, esse dependente de uma maneira diferente, que não seja apenas punindo. Sim, podem existir penalidades, limitações de alguma maneira, que também eles precisam de regras. O usuário precisa, muitas vezes ele precisa de regras, ele precisa seguir, ter uma rotina, tudo mais, mas não de uma maneira punitiva que seja prender ou qualquer coisa do tipo, porque ele vai sair... na cadeia a gente sabe tudo o que acontece. Então, você não recupera o indivíduo.

Pesquisadora - O ideal seria reinserir mesmo na sociedade ou, finalmente, inserir. E9 - Sim. Exato.

Pesquisadora - Está. É isso. Acabou. 


\section{ENTREVISTADO: E10}

Arquivo de Áudio:130807_003

Tempo: 00:15:14

Pesquisadora - Fala para mim, por favor, seu nome completo.

$\mathbf{E 1 0}-(\ldots)$

Pesquisadora - Qual que é sua especialidade?

E10 - Terapia Ocupacional.

Pesquisadora - Você trabalha com usuários de drogas há quanto tempo?

E10 - Desde 2008, quando eu comecei a especialização em Saúde Mental aqui na Unifesp. Pesquisadora - E aí o tempo todo aqui no PROAD.

E10 - Eu comecei a fazer o estágio aqui no PROAD. Aí eu continuei a especialização, mas eu nunca parei aqui no PROAD. Eu comecei o voluntário aqui no PROAD. Então, eu fazia paralelo à especialização e aqui no PROAD eu vinha uma vez por semana.

Pesquisadora - Tá. Quais as atividades que você desenvolve aqui?

E10 - Eu sou agora responsável pelo Setor de Terapia Ocupacional. Então, na verdade, eu agora estou fazendo só um acolhimento e fico mais responsável pela supervisão dos alunos que passam na especialização e dos alunos da Liga.

Pesquisadora - Tá. Pela sua experiência com os usuários, você acha que tem algum fator que você possa estar como recorrente para que eles busquem o tratamento? Algum...

E10 - Olha, o que eu sinto, na verdade, é que a busca espontânea acontece menos do que a busca pura, assim. Na verdade, o que mais acontece é aquela busca em que o mundo está desmoronando e eu preciso vir. Então, a minha esposa vai me abandonar, meus filhos estão se afastando de mim, minha vida vai acabar e aí eu venho. Então, é quando a vida está realmente no fundo do poço, mas, na verdade, eles sempre descobrem que sempre tem um fundo do poço pior que aquele.

Pesquisadora - O poço é maior, não é?

E10 - O poço sempre dá para cavar mais. Então, eles acham que estão no fundo do poço, eles aparecem, mas no decorrer do tratamento eles descobrem que o fundo do poço está mais embaixo. 
Pesquisadora - E você acha que tem, do mesmo jeito que tem essa situação de se perceber no fundo do poço como ensejadora de uma reflexão que traz par o tratamento, tem alguma coisa que pode ser considerada recorrente para que eles abandonem ou para que eles...

E10 - Eu acho que a fissura é o grande passo para a recaída, que eles chamam de recaída, que às vezes, é um lapso, mas que eles chamam de recaída que é o grande fator que atrapalha o tratamento. Então, a grande vontade de usar, que eles chamam de fissura. E aí eles não aguentam. E aí eles recaem. E aí eles ficam com vergonha e não voltam para o tratamento. E aí eles abandonam. Eu entendo que é isso que faz eles não voltarem para o tratamento. E abandonar o tratamento. Então, eles têm essa vontade muito grande de usar, usam e não voltam para o tratamento.

Pesquisadora - E você falou dessa vergonha. Você acha que esse elemento vergonha está presente até por eles serem usuários? Eles se sentem diferentes ou diminuídos em relação às outras pessoas por serem usuários de drogas?

E10 - Para alguns sim. Não para todos. Mas para alguns sim. Esse discurso aparece em algumas falas.

Pesquisadora - E existe uma diferença entre os usuários de drogas ilícitas e os usuários de drogas lícitas?

E10 - Os usuários de drogas líticas, os alcoolistas, na fala deles muitas vezes vem essa fala de: “Ah, mas eu não sou como eles. Eu uso álcool”. Então, na fala do usuário de álcool vem essa coisa de "eu não sou como eles. Eu sou diferente". Na fala do usuário de drogas ilícitas, não vem. Eles entendem que estão no mesmo barco e aí quando você vai falando e conscientizando, muitas vezes essa fala muda e o usuário de álcool começa a perceber que até é mais difícil conseguir parar de usar álcool porque o acesso é muito maior. Então, eles conseguem se conscientizar de que é até mais difícil parar de usar álcool porque se você for parar para pensar, daqui do PROAD até o metrô, Santa Cruz, tem 15 bares. E quantas bocadas a gente não sabe porque é um pouco mais escondido, não é? Então, começa nessa coisa: “Ah não. Mas ele é drogado. Eu só uso álcool”. Como se fosse um pouco menos grave ser alcoólatra, mas depois eles vão percebendo que é mais difícil, até, parar. Está mais aí. Está mais próximo. Pode até ser menos grave, mas não é menos complicado.

Pesquisadora - E aí dentre os usuários de ilícitas, você acha que tem um preconceito em relação aos usuários de crack?

E10 - Às vezes. Às vezes como se o crack fosse o fundo do poço. Como se: “Ah, não cheguei até ali ainda". 
Pesquisadora - E aí você acha que essa propaganda governamental pode...

E10 - Influenciar nisso? Acho que sim. Eu acho que não só influencia entre eles, mas na população geral. Como se o crack fosse o grande câncer do mundo agora. Tipo, é o grande problema, a grande doença que a gente tem hoje é o crack. E é irreal, não é?

Pesquisadora - E você acha que a disseminação dessa ideia é um reforço positivo para a procura de tratamento, por exemplo?

E10 - Não sei. Eu acho que não. Mas...

Pesquisadora - Por que você acha que não?

E10 - Ah, não sei se também estou muito enviesada. Acho que ...

Pesquisadora - Mas pode ser. Na verdade, é a sua opinião.

E10 - Eu acho que não. Acho que é uma grande bobagem. Eu acho que, na verdade, tipo, quem vai procurar tratamento, vai procurar tratamento. Acho que a forma como o governo está fazendo está dando medo na gente. A gente está ficando cada vez com mais medo e o medo não é uma coisa positiva. Ter medo das coisas não faz a gente ficar mais atenta, mais alerta. A gente tem que estar conscientizado das coisas e não com medo das coisas. E a gente tem medo do crack e a gente não está conscientizado do crack, não é? E é isso. Eu não acho que as pessoas vão procurar mais tratamento. Eu acho que... E nem o melhor tratamento. As pessoas vão procurar internação. E internação não é o tratamento porque o que se está procurando é internação e internação não é tratamento. Então, está tudo meio errado.

Pesquisadora - É. E ainda dentro desse contexto, você acha que uma primeira aproximação pela polícia, por exemplo, com viés eminentemente repressivo piora ainda mais...

E10 - Claro. Você está misturando tudo. Tratamento não é... Tratamento é uma coisa da saúde. Não da polícia. A polícia não dá tratamento. Quem dá tratamento são os profissionais da saúde. Quem tinha que ter chegado na Cracolândia não eram os policiais. Eram os profissionais da saúde. Quando chegam lá os policiais, você está reprimindo. Você não está tratando. Então foi tudo muito errado. Foi tudo muito torto. Então, é isso. Foi higienista. O que vem na minha cabeça toda essa coisa é a palavra 'higienização'. Então, você quer tirar as pessoas dali porque ficou feio e é muito doido. Você olha os bares, um monte de bêbado caindo na rua e isso não é feio. Agora, a Cracolândia é feio. E qual a porcentagem de bêbados batendo na esposa e qual a porcentagem de craqueiro batendo na rua, assim. É infinitamente menor, mas a gente tem que se preocupar com eles e não com os alcoolistas. É tudo muito louco. 
Pesquisadora - Você não acha que essa política criminal que mantém o usuário na condição de criminoso conversa com a política pública de reinserção social e tratamento?

E10 - Não. Não. Porque você está criminalizando alguém, você está colocando no mesmo lugar um criminoso e um doente. Não dá. Ou você olha ele como um criminoso ou você olha ele como um doente. Não dá para olhar como as duas coisas e querer dizer que você está tratando ele. Não dá. Ou você trata ou você criminaliza.

Pesquisadora - E os seus pacientes, quando trazem algum relato, se já trouxeram de contato com polícia, é um contato que se desenvolve de que forma?

E10 - Agressiva.

Pesquisadora - Sempre agressiva.

E10 - Nunca é positiva. Nunca é como: "Ah, o policial veio e me ajudou a ir para o tratamento". É sempre: "Eu fui preso e aí levei muita porrada, e aí eu saí e aí usei mais por um tempo e agora estou melhorando. Aí vim procurar tratamento".

Pesquisadora - E não tem nenhum relato de: "Fui para o fórum e o juiz me encaminhou"? E10 - Não. Quando eu trabalhei num lugar de internação que foi lá em Diadema, aí lá tem uma juíza em Diadema que ela encaminhava muito adolescente em internação compulsória, que é quando o juiz manda. Lá tem muita internação compulsória de adolescente. E é bem complicado porque quando a internação é compulsória, quem desinterna é o juiz. Então, por muitas vezes a gente tem paciente que você já fez tudo o que você tinha que fazer por ele e a gente fica esperando para dar alta a autorização do juiz. Então, essa é uma situação complicada, porque o familiar não vem. Você não consegue fazer um tratamento com a ajuda do familiar porque o familiar não visita. Então, que tipo de tratamento você está dando para esse cara? Para esse adolescente, porque a gente acredita que um bom tratamento para o adolescente é um tratamento que a família está envolvida. Então, você está só tratando o adolescente, você não está tratando a família, você não está tratando nada. Então, é muito complicado essas internações compulsórias também. Então, por isso que é difícil também quando envolve esse tipo de coisa. Então, o tratamento vem pelo juiz, mas não vem com uma ajuda. Então, o juiz deveria também impor que a família participe. Se é para fazer desse jeito, então o juiz tem que impor que a família participe porque aí você consegue pelo menos fazer alguma coisa maior, mas não dá. Fica muito dividido. O que é saúde e o que é o juízo. O que é tudo. É complicado.

Pesquisadora - E quais posturas, ou quais políticas ou quais ideias você acha que seriam interessantes para que a gente tratasse esse problema do uso de drogas de uma forma 
propiciadora da busca pelo tratamento. Quais as atitudes que o Estado poderia tomar? Como que eu poderia me comportar? Você tem alguma ideia?

E10 - Tem tantas.

Pesquisadora - Pode falar.

E10 - Na verdade, primeiro você precisa fazer uma conscientização nas escolas. Eu acho que educação nas escolas, porque aí as crianças vão sair já sabendo o que é a droga. Porque não usar é irreal. Não tem como não beber. É irreal. Vai se experimentar, vai se usar. É utópico falar que não vai usar. E aí,a partir do momento que você sabe que vai usar, você sabe como pedir ajuda. Então, a partir daí, não tem que pensar no reprimir. Tem que pensar no "se usar, usar como". Como pedir ajuda? Como tratar? Quais são as possibilidades de tratamento? Então, educação. Acho que tem que começar na educação. A partir daí, que tipo de tratamento que tem? Quais são as possibilidades? Redução de danos. Abstinência. Internação. Ambulatório. Capas. O que a cidade oferece? E é isso. Tem que legalizar? Não tem que legalizar? Eu acho que isso é uma discussão muito maior. Eu acho que tem que começar antes disso, porque legalizar ou não legalizar vai depender... No Brasil vai depender de uma coisa muito maior do que a reestruturação política desse país, porque legalizar do jeito que a política está, não vai adiantar nada porque os impostos não vão para onde tem que ir. Então, não adianta você legalizar nesse momento político do Brasil. então, não acho que essa é a questão nesse momento. Seria o ideal? Seria, mas não vai funcionar nesse momento.

Pesquisadora - O ideal seria como viabilizar que essas pessoas pudessem ter acesso ao tratamento.

E10 - Exato. Seria como educar familiares e os próprios pacientes a entender como se chega ao tratamento. Como pedir ajuda. Como que o familiar pede ajuda. Como chegar no tratamento. Como entender quando que o paciente precisa de ajuda. E não como internar o paciente. Porque internar o paciente não é a solução. E o que a política hoje diz é: Internar o paciente é solução. Eu vou lá, bato na porta do juiz e falo assim: “Olha, juiz. Meu filho está fumando crack. Interna ele para mim?” Aí vai lá o juiz e interna. E pronto. Acabou. Mas não é isso. E aí eu não visito mais. E o que eu fiz pelo meu filho? Nada. Eu simplesmente afastei o problema. E aí meu filho, depois de dois anos internado na comunidade terapêutica, volta para a mesma situação familiar, para o mesmo ambiente, para o mesmo trabalho que ele tinha, para tudo. Nada mudou. Aí o que ele vai fazer? Voltar para o que ele fazia, porque a 
única coisa que ele fazia era fumar. Nada vai mudar. A única coisa que mudou foi o elemento tipo o sujeito, mas nada mais mudou. Ele vai voltar e vai fumar.

Pesquisadora - É isso.

E10 - Então tá bom. Obrigada. 


\section{ENTREVISTADO: E11}

Arquivo de Áudio:130807_003

Tempo: 00:16:16

Pesquisadora - Bonitinho, não é?

E11 - É.

Pesquisadora - Fala para mim seu nome, por favor?

E11 - (...)

Pesquisadora - Qual sua especialidade?

E11 - Eu sou psicóloga.

Pesquisadora - Você trabalha com usuário de drogas há quanto tempo?

E11 - Eu estou há cerca de uns 3 anos, quase 4 com usuários.

Pesquisadora - E todo esse tempo aqui no PROAD?

E11 - No PROAD, no consultório e também no Hospital Estadual de Diadema. Lá a gente tem um hospital geral, a gente tem uma enfermaria de Psiquiatria, que só atende casos de dependência química.

Pesquisadora - Ah, que legal.

E11 - Trabalho lá também tem uns dois anos mais ou menos.

Pesquisadora - Pela sua experiência, você acha que tem... Eu vou falar dos usuários no geral e de vez em quando vou pedir para a gente pensar um pouco mais nos de crack, porque são da minha amostra.

E11 - Então é do grupo, claro.

Pesquisadora - Quando os usuários procuram tratamento, eles trazem relatos de fatores comuns no discurso? Então: "Eu procurei tratamento por essa situação". Existe alguma situação que você pode citar como mais comum? Como ensejadora dessa busca?

E11 - Existe. Eu acho que para a classe média, diferente do que para a classe baixa, porque para a classe baixa, muitas vezes, eles já tiveram passagens pelo tráfico e pela polícia. E são essas perdas que envolvem a marginalidade, a criminalidade que, às vezes, faz o sujeito procurar o tratamento sim. O que é muito comum, às vezes, acontecer no hospital que eu trabalho é eles chegarem por uma via da legalidade mesmo. Assim, no sentido de que eles estão sendo procurados. Então, eles estão procurando um lugar para se esconder. E às vezes, nem é de fato olhar o hospital ou olhar o tratamento como lugar para se tratar, mas mais um 
lugar para se proteger. Isso é uma realidade lá que eu trabalho. No consultório aqui no Proad é um pouco diferente. Mas existem sim relatos comuns e os relatos são, na maioria, de perdas. Então, quando o sujeito ainda consegue ver só prazer no uso, ele não procura o tratamento. Quando ele percebe que aquele objeto de prazer se tornou um objeto de necessidade e que aquele objeto de necessidade faz com que ele consiga elencar algumas perdas, então, ele consegue vir para o tratamento. E aí as perdas são perdas familiares, quer dizer, separação, os filhos que deixam de falar com o pai ou com a mãe. Perda de trabalho. Perda das atividades profissionais. Eu acho que isso vai bem comum. É bem comum mesmo. Pesquisadora - Pensando naquele grupo do hospital, que é um grupo que tem um pouco mais de relação com a criminalidade, é uma criminalidade relacionada com o tráfico ou com o uso da substância? Com o simples fato de ser usuário e poder ser submetido a uma medida judicial?

E11 - Tem as duas coisas. Mas mais os envolvidos com o tráfico.

Pesquisadora - Está. E existe muito encaminhamento de juiz, alguns encaminhamentos de internação compulsória ou não?

E11 - A gente trabalha numa estrutura diferente. A nossa internação é uma internação com período curto. Ela é ligada, a enfermaria é razoavelmente ligada ao PROAD. Ela tem um jeito de funcionar meio parecido com o PROAD. Então, os pacientes todos ficam cerca de 15 dias a 1 mês lá com a gente. E, como é um período curto, que seria para desintoxicar esse paciente, para sensibilizá-lo a voltar para o serviço de origem, porque são todos pacientes referenciados. Então, todos eles vêm de CAPS e a gente sensibiliza esse cara a voltar para o CAPS, a voltar para o ambulatório, enfim, a voltar para o seu serviço de origem. Então, também, além disso, é uma internação voluntária. A gente passou por um período que começamos a receber algumas ordens judiciais. Aí o hospital tem que acatar. E agora, nesse ano, tem sim alguns casos, consigo pensar mais ou menos agora nuns 6 ou 7 de, principalmente, adolescentes que vêm por ordem judicial. A gente barra bastante porque a gente questiona. Se dá para encaminhar para outro lugar, a gente tenta colocar um pouco nossa forma de pensar, nossa filosofia, nosso jeito de conduzir o tratamento. Mas na impossibilidade disso, eles vêm e eu, inclusive, estou com um caso desses agora. Tem uma menina lá que está há 3 meses internada que está por ordem judicial.

Pesquisadora - Está. Mas é mais para adolescente. Adulto tem?

E11 - Já tivemos adulto, mas é mais frequente com adolescente. Pelo menos do tempo que eu estou lá. 
Pesquisadora - Você acha que os usuários - e aí pensando no geral - se sentem diferentes das outras pessoas? Carregam algum estigma por serem usuários de drogas pura e simplesmente?

E11 - Sem dúvida. Sem dúvida carregam. Eu acho que eles carregam um sofrimento diferenciado, porque eu acho que há um perfil de pessoa que lida com o sofrimento diferente do resto e é uma minoria. Não é uma maioria. Quer dizer, a gente tem um grupo grande de pessoas que usam, mas a maioria das pessoas não viciam. E as pessoas se viciam por motivos completamente singulares também. E acho que essas pessoa que se reconhecem, que sabem que são dependentes sim. Elas sofrem sim. Acho que são estigmatizadas sim e se sentem assim, diferenciadas do resto do grupo. Com certeza. Isso está muito no imaginário social. Inclusive delas.

Pesquisadora - Entendi. E em relação aos usuários de drogas ilícitas, em relação aos usuários de drogas lícitas. Você acha que tem um peso maior?

E11 - Acho que sim, também. Essa nomenclatura álcool e outras drogas, é uma nomenclatura superrecente, na verdade, porque até então, quando a gente falava ‘dependência química ou drogas' não passava pelo imaginário de ninguém que isso envolvia álcool, por ser uma droga lícita, por exemplo. E quando a gente muda essa nomenclatura é para também acolhe esse público. O alcoolista, por acessar a bebida fácil, ou por ser uma droga reconhecida e até permitida em algumas ocasiões, na maior parte do tempo, as pessoas também não se dão conta que se tornam dependentes daquela substância. Então, sim. Há diferença, tanto que os usuários de álcool, na minha opinião, muitas vezes são preconceituosos com os usuários de outras drogas: "Ah, o outro usa droga". Eu falo: "Mas você não usa também?” então, assim, até dentro do grupo dos dependentes há uma diferença entre os alcoolistas e os outros usuários, os usuários que fazem uso de outras substâncias.

Pesquisadora - E você pode perceber essa mesma diference entre usuários de ilícitas como um todo e os usuários de crack?

E11 - Menos. Menos. Eu acho que o crack é uma droga recente na nossa cultura. Ela data mais ou menos no final dos anos 80 , começo dos anos 90, senão me engano. Desculpa se estiver errada.

Pesquisadora - Não. Está certo.

E11 - E ela é um fenômeno... É a droga mesmo da marginalidade. É o resto da cocaína, que é a droga do capital. O cara cheira cocaína com todo um ritual. É cara e o cara cheira cocaína com a nota de um dólar e separa carreira com um cartão de crédito. E o crack é o subproduto 
disso e, por ser subproduto disso, é também utilizado pelos marginais. O que acontece muitas vezes, hoje em dia o que eu percebo, não sei se é uma leitura equivocada minha, mas a sensação que me dá é que mesmo pacientes que nunca fizeram uso do crack têm usado pelo acesso fácil. Pelo preço. Pelo custo da substância. Eles não só usam o crack. Muitas vezes eles fazem usos cruzados. Usam outras substâncias além do crack. Têm preferência pelos estimulantes. Por isso escolhem o crack. E acessam pelo custo e que, por essa questão, por esse conceito de ser uma droga marginal, alguns, eu diria aí que num grupo de 100, vamos pensar assim, uns 60 se sentem mal por usarem o crack, por ser uma droga dos marginalizados. Mas, na sua maioria, cada vez mais eu tenho visto as pessoas acessando, pessoas de classe média acessando, pelo custo mesmo, e acho que rola ali um preconceito até de quem usa. Um certo desconforto de quem está usando, mas eu não sei se fica tão clara essa divisão quanto fica para quem usa, por exemplo, álcool ou até para quem é fumante. E as outras substâncias.

Pesquisadora - Está. Eu te fiz essa pergunta porque vou te fazer uma pergunta de opinião agora. Essa propaganda toda do governo em relação ao crack como o maior problema, você acha que pode ser um fator incentivador para a busca pelo tratamento? Ou é um fator que aumenta o estigma e, de repente, afasta esse indivíduo da saúde?

E11 - Eu acho que ela está muito equivocada essa política, na realidade. Eu acho que é uma política que não tem como objetivo pensar o tratamento. Tem uma questão muito política nisso aí, na verdade.

Pesquisadora - Por quê?

E11 - Econômica, política. Não acho que esse governo é um governo preparado para pensar em formas de tratamento, pensando pelas intervenções que fizeram, não sei se foi no começo do ano, ano passado, acho que foi ano passado, senão me engano. As intervenções que fizeram na Cracolândia, por exemplo. Falando de São Paulo. São Paulo, por exemplo, eles entraram na Cracolândia de um jeito superostensivo, de um jeito que não convidava ninguém a se tratar, que não convidava ninguém a ser cuidado. Os agentes de saúde não faziam esse trabalho junto com a polícia. Ou seja, um órgão não fiscalizava outro. Então, a polícia fazia esse trabalho sozinha. Eu li, enfim, na Carta Capital, na época, que parte da droga apreendida era mais ou menos o que um usuário de crack da Cracolândia usa num mês, ou seja, muito pouca droga apreendida e dá um tom de que o usuário de crack é bandido. E não doente, ou alguém que sofre. Nesse sentido, eu acho que isso afasta as pessoas do tratamento. Eu não acho que aproxima. A intervenção foi feita sem que fosse aberto aquele posto, aquele espaço 
que seria um centro de vivência junto com centro de tratamento. Eu nem sei se esse centro hoje em dia já foi aberto. Mas, na época em que fizeram a apreensão e a dispersão das pessoas que, para mim foi uma política higienista total, eles fizeram essa intervenção sem que esse lugar estivesse aberto. Quer dizer, as pessoas foram expulsas daquele ambiente sem ter para onde ir, sem ter para onde recorrer. Isso você não trata. Se você não aproxima o cara com tratamento. Você afasta ele. Você cria medo. Você cria repulsa. Você cria medo. Você cria um monte de coisa. Um monte de coisa que faz ficar longe de você. Não fica perto. Então, nesse sentido, eu acho que essa política brasileira da guerra contra o crack, eu acho que ela é superequivocada e acho que ela tem como objetivo não tratamento, não objetivo de saúde. É um objetivo político, simplesmente.

Pesquisadora - Você não acredita, então, que um primeiro contato repressivo possa evoluir para uma situação de acolhimento?

E11 - Eu acho que o primeiro contato tem que ser um contato convidativo. Não repressor. Porque a repressão afasta. Ela não aproxima. Ela não é convidativa. Essas pessoas todas, o crack é sintoma. O uso do crack é um sintoma. Não é uma causa. Essas pessoas precisam de acolhimento. Precisam de cuidado. Quando você chega lá numa política repressora, essas pessoas não se sentem nem um pouco a estar juntas ali, a pensar na possibilidade de se aproximar de algum lugar de cuidado. Pelo contrário, elas ficam completamente ansiosas. A gente passa, então, a criar no imaginário do usuário de crack como alguém que é marginalizado e que também é bandido porque precisa da intervenção da polícia e da Justiça para acessar essa população. No Rio, por exemplo, foi interessante. Apesar de todos os problemas que o Rio tem, que eu acho que tem em termos de administração, eles fizeram essa intervenção nos locais aonde tinha um grupo grande usuários, como, sei lá, Cracolândia deles lá, que eu não sei como é que chama, essa intervenção foi feita junto com agentes comunitários. Então, um órgão físcalizava o outro. Então, a ação da polícia foi menos ostensiva, o que convidou parte desses usuários a pensar a frequentar algum lugar. Em outros países, como o Canadá, por exemplo, existem alguns espaços que são completamente diferentes, que são funcionais. Então, o usuário de heroína, por exemplo, é convidado a entrar numa clínica onde ele pode fazer o uso assistido. Aí ele usa lá dentro, na parte de baixo, seria um espaço que eles chamam de insight, que seria a parte onde ele vai lá. Eles dão agulha descartável por uma questão total de política pública, para não ter contaminação entre um usuário e outro, já que eles usam heroína que é droga injetável, quer dizer, feita de jeito injetável lá. E aí, eles usam, eles fazem um uso assistido. Usam agulha... Descartam a 
agulha lá. Se, de repente, tem uma overdose, tem gente que cuida ali. E aí eles começam a se aproximar desses usuários, esses usuários a se aproximar dessa equipe técnica que trabalha nesse lugar, para, então, depois, num segundo momento, quando eles estiverem sensibilizados, eles podem ir para o tratamento. Isso sim eu acho, no meu mundo perfeito, na minha ideia de tratamento, que é se aproximar do usuário. É acolher, escutar, é estar junto. Às vezes fazer intervenções desse tipo, que não seja, às vezes, discriminando o uso, mas sim entendendo que essa pessoa, porque dela fazer esse uso. Dar até um espaço, de repente, para ela estar perto. Isso sim eu acho que é uma forma viável de pensar em tratamento. Essa política brasileira não. Não acho que é viável.

Pesquisadora - E os relatos que você já ouviu de pacientes sobre qualquer tipo de aproximação, enfim, eu posso pensar por vários agentes públicos, mas um assistente social ou um policial. Os relatos das aproximações dão conta mais de uma aproximação de polícia ou de assistência?

E11 - Tem os dois relatos. Como eu trabalho em Diadema, existe um grupo tanto em São Bernardo, quanto Diadema, grande que faz um trabalho de rua que é chamado Consultório de Rua. Eles se aproximam dos pacientes in locu e aí eles convidam esses pacientes a frequentar o CAPS ou um centro de convivência para começar a tratar a questão da dependência. Isso eu acho muito legal. E aí tem alguns pacientes, principalmente moradores de rua que trazem relato positivo dessa aproximação. Tem também muitos pacientes que trazem relatos da polícia e o relato da polícia, relato de um contato sempre muito agressivo, principalmente da Rota, que é ofensivo, é humilhante, que eles têm ou não tem isso muito com adolescente, ou seja, quem está vulnerável. Mulheres, adolescente, crianças, é sempre um relato ruim. É sempre um relato negativo. É sempre muito... É um contato ruim e que não é convidativo. A polícia não chega e aí de repente acolhe essas pessoas iriam para algum lugar de tratamento. Não. É sempre no sentido de fiscalizar e de, de repente prender e de repente ofender ou assustar. É sempre nesse sentido.

Pesquisadora - Mesmo quando existe, por exemplo, a prisão ou a forma de conduzir não é respeitosa.

E11 - Nunca.

Pesquisadora - Está. É isso.

E11 - É isso? Não sei se eu consegui... 


\section{ENTREVISTADO: E12}

Arquivo de Áudio:131008_001

Tempo: 00:11:57

Pesquisadora - Me fale o seu nome completo, por favor.

E12 - É E12.

Pesquisadora - Só [nome]?

E12 - Só.

Pesquisadora - Que delícia nome curtinho, o meu é gigante. Qual é a sua especialidade?

E12 - Eu sou psiquiatra.

Pesquisadora - E você trabalha com usuários de drogas há quanto tempo?

E12 - Desde 90, fazem 23 anos.

Pesquisadora - Nossa, muito tempo. E todo esse tempo foi no PROAD ou você teve passagens por outros lugares?

E12 - Sempre no PROAD, hoje eu estou coordenando uma enfermaria de tratamento de álcool e droga no Hospital Geral em Diadema.

Pesquisadora - Legal, eu conversei com a (...).

$\mathbf{E 1 2}-\mathrm{A}(\ldots)$.

Pesquisadora - Que deve trabalhar com você. Já falei com ela.

Nesse tempo que você trabalha com usuário de droga, como a minha amostra... $\mathrm{Na}$ verdade eu não te falei isso antes, ou falei? A minha amostra é restrita ao usuário de crack, então eu pergunto dos usuários no geral porque eu acho que é bom ter uma visão global, têm algumas perguntas que, aliás, elas necessitam de uma visão geral, mas de vez em quando eu vou te pedir para focar nos usuário de crack ou para, pelo menos, fazer uma observação em relação a eles.

Nesse tempo todo, muito tempo que você já trabalha com o usuário de drogas, você acha que tem algum fator que eles tragam de forma comum como ensejador da busca pelo tratamento? Então é "Por que é que decidiu buscar me tratar?".

E12 - Normalmente a frase mais comum é: "Cheguei ao fundo do poço, não tenho mais nada. Preciso me tratar agora porque senão eu vou morrer, não tenho mais chance nenhuma.”. Essa é a motivação mais forte: "Perdi tudo". Essa é...

Pesquisadora - É sempre uma situação de limite? 
E12 - De limite.

Pesquisadora - E eu imagino que deva ter muitas pessoas que abandonem o tratamento.

E12 - Hum, hum.

Pesquisadora - Existe alguma razão para que eles abandonem que também seja comum?

E12 - Normalmente a recaída faz com que as pessoas tenham dificuldade de voltar, como se fosse algo que fosse: "Não mereço mais o tratamento", algo assim, "Eu recaí, então não adianta mais nada mesmo", é sempre um olhar meio derrotista, de total...

Pesquisadora - E você acha que essa derrota, que eles se sentem, enfim, como derrotados, ela é reforçada, ela surge com a recaída ou ela é reforçada com a ideia da recaída porque por serem usuários eles já se sentem como derrotados?

E12 - Eu sinto que ela é reforçada pela recaída, recaída é um sintoma de algo que já estava ali.

Pesquisadora - E os usuários, que no geral se sentem derrotados, você acha que existe uma diferença entre esse sentimento de derrota pessoal ou um preconceito entre os usuários que são de drogas ilícitas para os usuários de drogas lícitas?

E12 - Nesse aspecto não, acho que são muito parecidos. Se você pensar álcool e o crack é muito parecido nesse sentido, os dois abandonam o tratamento do mesmo jeito, há recaídas. Acho que...

Pesquisadora - E uma sensação de estigma num geral, assim, em uma primeira apresentação o usuário da droga ilícita, ele se sente diferente do da droga lícita ou também...? E12 - Muitas vezes sente. Sente sim, isso é outra coisa que você ouve muito: "Ah não, droga química não, meu lance é álcool e tal. Química não”. Então algumas vezes tem um certo preconceito, por exemplo, dos alcoolistas em relação aos usuários de outras drogas. E os usuários de outras drogas, inclusive o crack, olham o álcool como: “Ah, você não sabe o que é uma coisa pesada.", por exemplo.

Pesquisadora - E entre os usuários de ilícitas em relação aos usuários de crack, existe esse preconceito também?

E12 - De ilícitas?

Pesquisadora - É.

E12 - Não, bem menos. Talvez em relação à maconha, muitos usuários só de maconha não gostam nem de crack e nem cocaína, e muitos usuários de crack já abandonaram a maconha há muito tempo. Mas não na mesma coisa de preconceito ou algo assim. 
Pesquisadora - Os usuários que passaram por você, muitos relataram alguma relação com polícia ou com o Poder Judiciário?

E12 - Sim.

Pesquisadora - E como geralmente é esse relato? É um relato de uma situação que enseja uma reflexão, uma situação de acolhimento ou uma situação desagradável, agressiva?

E12 - Coisa ruim, na maioria das vezes falam: "Eu escapei dessa”, e quando não escapam é uma coisa, em geral, bastante traumática.

Pesquisadora - E como é que você entende essa abordagem traumática para esse indivíduo em relação a esse raciocínio pelo tratamento, assim, passar por uma situação traumática leva uma pessoa a procurar ajuda ou afasta essa pessoa da ajuda pelo trauma?

E12 - Nunca vi ninguém buscar ajuda a partir disso, a não ser quando tem uma ordem judicial que obriga o cara a ir ao tratamento, aí, em geral, ele vai lá porque ele precisa de uma assinatura. Não...

Pesquisadora - Ele continua depois?

E12 - Alguns sim, alguns você consegue motivar. Outros não, quer dizer, muitos não, eu nunca fiz uma pesquisa desse tipo, mas eu acho, pensando e lembrando de algumas coisas, a maioria não vai voltar.

Pesquisadora - Entendo.

E12 - Então, se você tivesse que escolher para uma política pública entre uma primeira abordagem ao usuário, pensando agora no usuário de crack, você pensa que é mais interessante uma abordagem de acolhimento ou uma abordagem de repressão?

Pesquisadora - Uma abordagem de acolhimento, sem dúvida.

E12 - E por quê?

Pesquisadora - Repressão não adianta nada, punição não adianta nada, não motiva ninguém a tratar. E o acolhimento, por outro lado, pode de alguma forma motivar essa pessoa a um determinado momento poder se tratar. Pode ser que não também, mas se tem alguma possibilidade maior é pelo acolhimento. Assim, já ouvi, isso é uma questão supercomplexa porque, assim, já ouvi relatos de jornal, coisa assim, que: “Ah, se não tivessem me levado à força naquela época eu estava no fundo do poço agora.”. Essa não é a minha abordagem nem da maioria das pessoas que eu trabalho, então eu não tenho essa amostra. Minha amostra é uma amostra que volta quando você acolhe. Então não posso pensar de outro jeito.

E12 - Só mais uma pergunta: você acha que, eventualmente, uma agressão pode aumentar essa sensação de inferioridade ou de derrota? Essa abordagem que reprime? 
Pesquisadora - Pode, pode aumentar a revolta, em algumas pessoas isso fica marcado para o resto da vida, mesmo que ele se trate por outro motivo, sei lá, mas fica marcado para o resto da vida.

E12 - E aí seria um dificultador nesse tratamento?

Pesquisadora - Sim.

E12 - Como é que isso dificulta?

Pesquisadora - Assim, é como se você reforçasse a defesa desse cara, como se você reforçasse que: "Está vendo? Desse jeito que me tratam, assim eu nunca vou me tratar mesmo, eu vou ficar no fundo do poço”, em geral tem uma posição ideológica, tem pessoas diferentes e isso acho que é uma coisa... São pacientes muito diferentes, ainda que usando a mesma droga. Digamos o crack: alguns são mais pacíficos e aceitam mais essa coisa de alguém poder guiá-los nessa história, ou sente a repressão como um guia para que ele saia daquela história, mas de alguma forma eu acho que das duas uma; ou ele fica absolutamente dependente sempre de que alguém o guie naquela coisa ou ele, de alguma forma, vai recair, vai se retrair ainda mais.

Das pessoas que conseguem durante o tratamento assumir um protagonismo em relação à sua própria droga: "Eu uso mesmo", quer dizer, assume: "Eu uso mesmo, eu estou ferrado, eu quero sair disso", na hora que recebe uma punição ou uma repressão maior, isso é extremamente contraproducente. É como se você enfraquecesse o indivíduo que está começando a criar uma possibilidade de trabalhar com a própria escolha. Isso revolta muito, é como se você tirasse a possibilidade de escolha desse indivíduo e ele estava, de alguma forma, começando a pensar nisso. Ou acreditava que podia. Ou se a gente não puder acreditar que esse cara tenha alguma possibilidade de escolha... Assim, você está tirando dele uma coisa que é vital, você vai transformar ele em um robô: "Olha, é assim, assim, assim e assim" e provavelmente não vai dar certo em menor ou maior tempo.

E12 - Você acha, então, que a política criminal, que mantém a criminalização do usuário, ela pode prejudicar a política de saúde ou elas podem caminhar de forma harmoniosa?

Pesquisadora - Eu acho que prejudica, eu acho que é um passo para trás. Eu acho mesmo que é um passo para trás na possibilidade que você tem de poder avaliar a questão da dependência de uma forma muito mais ampla, quer dizer, a dependência não é uma coisa só, não é porque o cara usa crack e o outro usa crack também que ele é igual, são diferentes, as abordagens têm que ser diferentes, não pode criminalizar toda essa história e colocar todo mundo no mesmo saco. Você não vai estar fazendo... Você vai estar dando um passo atrás e 
um passo atrás no sentido de você poder achar alternativas, que a gente ainda não tem, mas com certeza não é pela repressão que você vai achar alternativas. Você vai achar alternativas de outro jeito: acolhendo, vendo do que se trata, vendo quantos tipos têm. Você vai criminalizar se o cara fez algo, fez uma escolha que é criminalizável num certo sentido: se ele roubou, se ele matou, aí eu acho que ele tem que responder pelo que ele fez, mas não pelo seu uso. Ele tem que assumir a sua própria responsabilidade pelo uso, eu acho isso. E12 - Obrigada.

Pesquisadora - De nada. 


\section{ENTREVISTADO: E13}

Arquivo de Áudio:131015_001

Tempo: 00:24:56

Pesquisadora - Fale seu nome completo.

E13 - [nome].

Pesquisadora - Qual é a sua especialidade?

E13 - Eu sou psiquiatra.

Pesquisadora - Desde quando você trabalha com usuário de droga?

E13 - Clinicamente? Poxa, já é uma pergunta difícil já, já começou mal.

Pesquisadora - Por quê?

E13 - Eu trabalho, eu faço pesquisa com dependência química há 12 anos. E eu trabalho atendendo dependentes químicos há 9 anos. Nos 3 primeiros anos eu trabalhava sob supervisão, eu era aluno de medicina, eu não podia... Eu não respondia oficialmente pelo meu atendimento, mas eu atendia e discutia os casos com a minha supervisora. E há 6 anos eu trabalho... Eu continuo fazendo pesquisa, mas eu trabalho assistencialmente, respondendo pelos meus atos com os dependentes.

Pesquisadora - E você trabalha no PROAD e no consultório particular?

E13 - E no Pronto Socorro do Hospital São Paulo, que eu trabalho até o dia 02 de novembro, porque eu pedi demissão; e no Hospital A. C. Camargo. No Hospital A. C. Camargo, embora seja um hospital específico para tratamento de câncer, eu concentro os casos de dependência química.

Pesquisadora - E qual é a sua função no PROAD?

E13 - No PROAD eu coordeno o setor de adultos e o setor de adolescentes. Então eu coordeno a parte assistencial dos pacientes adultos e adultos incluem fundamentalmente homens, mas as mulheres que não entram no setor de mulheres por qualquer motivo, ou porque não tem vagas ou porque elas não gostam de estar só com mulheres, vão para o setor de adultos. E do setor de adolescentes, que é dos 13 aos 18 anos. E dentro do setor de adultos eu oriento os residentes de psiquiatria, de psicologia, de enfermagem.

Pesquisadora - Você acha, pela sua experiência trabalhando com usuário, que existem alguns fatores que podem ser considerados como mais importantes para a busca pelo tratamento? Eles relatam algumas motivações com frequência? 
$\mathbf{E 1 3}$ - Eu acho que tem algumas coisas que pesam para um paciente buscar tratamento. Eu acho que um dos motivos mais importantes é a pressão da família, eu acho que é uma das coisas que mais aparecem, tanto no PROAD quanto no consultório. Acho que o fato da família pressionar, não tanto obrigar porque eu acho que muito poucos, quando cedem à pressão da família já não é mais obrigado pela família, existe um desejo de ser tratado. Mas eu acho que a pressão da família, o fato de ter alguém o tempo todo falando sobre o uso, apontando os problemas do uso, acho que isso é um fator bem importante.

Eu acho que nos pacientes mais velhos um pouco pesa muito a ideia de "o que eu fiz com a minha vida". Então quando os pacientes param para refletir sobre que rumo eles deram para as suas vidas, quais as escolhas que eles foram fazendo e o que eles construíram nas suas vidas, acho que esse é um momento que muitas vezes ajuda na busca pelo tratamento. Porque eles se dão conta do quanto a droga dominou a vida deles e o quanto eles deixaram de construir coisas ou perderam coisas em função do uso de substância.

Isso pensando bastante nos dependentes mesmo. Eu acho que tem uma leva importante de pacientes, isso mais no consultório particular do que no PROAD, que procura ajuda às vezes antes da dependência se instalar, quando eles têm ainda um uso nocivo, um uso que começa a se tornar problemático, que procura ajuda porque começa a perceber os problemas que a droga está trazendo, ou porque tem alguém na família que já teve as consequências todas nocivas que a droga já trouxe, são pessoas que estão começando a ver o seu potencial ser desperdiçado. Então eu acho que pessoas mais jovens que estão começando nesse caminho da dependência ou estão começando a ter o uso disfuncional, elas vêm muito com esse discurso de que: “Ah, eu sou jovem, eu sei o quanto eu tenho potencial, o quanto eu estou vendo as pessoas da minha idade se desenvolverem e eu tenho medo de desperdiçar a minha vida nisso.”.

Acho que esses são os principais.

Pesquisadora - E você acha que tem algum fator importante para que o usuário abandone o tratamento?

E13 - Eu acho que sim, eu acho que é muito mais fácil abandonar o tratamento do que chegar ao tratamento. Acho que têm alguns fatores que pesam, que são fatores que pesam para abandono de tratamento na psiquiatria, não só na dependência química. Ao mesmo tempo que a pressão da família faz os pacientes procurarem, acho que a pressão dos pares faz os pacientes abandonarem. Então, é muito comum os pacientes depois que... E aí os pares podem ser outros usuários como pode ser a própria família. Então é muito comum os 
pacientes, principalmente de álcool, falarem que depois que param de beber a família começa a incentivar de novo o consumo: "Ah, mas não precisa ser tão radical, toma um copo, toma uma taça, agora você está exagerando também.”.

Acho que também as pessoas, e aí acho que tem um viés no meu discurso de ser psiquiatra e de passar medicação para a maior parte dos pacientes, de que as pessoas têm muito preconceito com medicação ainda, com medicação prescrita pelo psiquiatra, e as pessoas não querem tomar a medicação prescrita pelo psiquiatra, os próprios pacientes têm esse preconceito, as famílias têm esse preconceito, então o psiquiatra fala durante 20 minutos, meia hora, uma hora sobre os benefícios do remédio. A família está o dia inteiro, todo o dia, falando para o paciente: "Ah, isso é bobagem, você não devia estar tomando isso. Para com essa porcaria.”. Então, isso pesa muito para o paciente interromper a medicação que muitas vezes está ajudando no tratamento, e que a interrupção abrupta da medicação pode levar a uma recaída e a interrupção do tratamento. A interrupção da medicação pode fazer o paciente achar que a medicação é o todo do tratamento e abandonar o tratamento multiprofissional só porque parou o remédio. Então acho que esse também é um outro ponto importante.

No PROAD, principalmente, a gente vê também como fator para abandono do tratamento a falta de recursos financeiros. Então embora o tratamento ideal devesse ser regionalizado, especialmente o PROAD que é vinculado a uma Universidade, ele tem a função de ser um serviço escola. Pegar os casos mais complexos e pegar os casos ligados ao Hospital São Paulo, que não é regionalizado. Então a gente tem muitos pacientes da Grande São Paulo. Então o custo de frequentar um tratamento que não é um tratamento de uma vez por mês, é um tratamento semanal, duas vezes, três vezes na semana, pesa muito para os pacientes abandonarem também.

E a gente tem muitos pacientes que simplesmente desaparecem. Tem uma parcela de pacientes que simplesmente desaparecem, passa na primeira entrevista e nunca mais retorna para o tratamento. Esses pacientes, a gente tem muitos que são um grande mistério. $\mathrm{Na}$ verdade a maior parte deles é um grande mistério, a gente não sabe por que eles nunca retornam, então a gente sabe que a taxa de sucesso no tratamento da dependência química é de 35\%. Então, provavelmente, uma boa parcela desses pacientes não foi com a cara da nossa abordagem, não gostou do que ouviu, não gostou do médico, não gostou do lugar, enfim, acho que tem uns fatores subjetivos que a gente nunca vai conseguir acessar. Acho que tem uma parte da motivação também, o paciente dependente, ele é muito ambivalente, então ao 
mesmo tempo que ele tem um desejo de se tratar ele tem um desejo de continuar usando. Acho que o nosso grande desafio é fazer com que essa ambivalência pese mais para o nosso favor, pese mais para o lado dele parar de usar e se engajar num tratamento. Então acho que não necessariamente buscar um tratamento é desejar se manter no tratamento, às vezes é só sondar as possibilidades para, quem sabe, num futuro voltar e se engajar de verdade.

Pesquisadora - E você acha que têm alguns fatores que não impedem, mas que funcionam como uma espécie de bloqueio para a pessoa procurar o tratamento? Pensando na primeira vez que a pessoa vai procurar.

E13 - Acho. Eu acho que tem uma questão do estigma associado ao uso de drogas. Eu acho que isso é o mais importante para a pessoa não chegar ao tratamento, acho que a pessoa não reconhecer que é um problema ou ter vergonha de procurar ajuda por isso. Ter medo de como vai ser tratado, ter medo de como vai ser a receptividade dos profissionais. Bom, não sei se cabe, mas eu vou continuar falando, foi bem interessante hoje, eu atendi um paciente no A. C. Camargo que aconteceu uma coisa muito grave com ele, ele caiu no sábado, bateu a cabeça, e aí domingo ele acordou e começou a ter uma alteração de comportamento. É muito grave e foi muito agudo, ele bateu a cabeça sábado à noite e domingo de manhã ele estava bizarramente esquisito. E aí ele foi ao Pronto Socorro do hospital hoje e a plantonista falou: "Não, isso é porque ele bebe.”. Eu falei: “Não, isso não é porque ele bebe. Ele vai voltar lá agora, eu vou fazer uma carta, porque isso é muito grave. Ele pode estar com sangramento no cérebro, ele pode estar com um milhão de coisas acontecendo.”. E aí a esposa dele começou a chorar e falou: "Eu senti que houve um preconceito da médica quando eu falei que ele fazia tratamento para bebida.”. Então essa é a reação normal dos profissionais de saúde em geral. Então o paciente acha que é isso que ele vai encontrar num lugar específico para dependência. Ele não sabe que num lugar específico para dependência as pessoas vão estar treinadas para lidar com isso, acostumadas a lidar com isso, então é muito difícil vencer esse preconceito que eles esperam encontrar, é o preconceito com o qual eles têm que lidar no dia a dia deles.

Acho que tem uma questão de acesso ao serviço, acho que... A gente sabe que os pacientes mais graves de todas as doenças não chegam ao serviço de saúde. Os pacientes mais graves com tuberculose não chegam num serviço de saúde, os pacientes mais graves com diabetes não chegam num serviço de saúde, os pacientes mais graves dependentes não chegam no serviço de saúde. Então eu acho que isso também é um problema importante, os pacientes não conseguem acessar, os pacientes em condições mais precárias, que seriam os 
que mais precisam de ajuda, isso é muito sério. Acho que a gente tem uma oferta de serviços que ainda é deficitária, a gente tem... Eu não sei se a gente tem um número insuficiente de serviços - estrutura física. Mas eu não tenho dúvida de que a gente tem um número insuficiente de profissionais e profissionais mal treinados. Então têm muitos CAPS funcionando sem psiquiatra, têm muitos CAPS que contratam psicólogos, terapeuta ocupacional ou psiquiatra que não têm experiência em dependência química, e isso faz muita diferença, você ter um profissional que sabe lidar com isso. Então eu acho que a escassez de mão de obra, acho que um pouco a escassez de infraestrutura, mas muito mais a escassez de mão de obra, ela é um fator que dificulta o acesso ao tratamento. Porque o paciente às vezes pode até buscar o tratamento, mas não tem vaga, só tem vaga para a semana que vem, e a gente sabe que o dependente, quando ele procura ajuda ele precisa da ajuda imediatamente. Porque a droga vai resolver o problema dele imediatamente. Então o serviço de saúde precisa minimamente tentar resolver a angústia dele imediatamente para que ele não saia dali e: “Ah, não tem vaga eu vou cheirar", ou então: "Eu vou fumar".

Então acho que o acesso, o estigma, e a própria gravidade são fatores que barram a chegada no serviço.

Pesquisadora - Você falou do estigma, enfim, das pessoas no geral em relação aos dependentes químicos. Você acha que entre os dependentes existe um preconceito entre dependentes de drogas lícitas em relação aos dependentes de drogas ilícitas?

E13 - Sem dúvida, sem dúvida. A gente não consegue derrubar o hábito de falar "álcool e outras drogas". Então as pessoas que... Começa que cigarro não é droga, não é? Isso é universal, as pessoas não consideram o cigarro uma droga, um problema, e aí já começa errado. Aí você vai para o álcool e é “álcool e outras drogas”, então o álcool já está em um patamar diferente. E isso mesmo entre os profissionais, nos congressos, no nome dos serviços. Então, o nome do serviço de tratamento é CAPS-AD, CAPS Álcool e Drogas. Não, o álcool está no bolo das drogas. Então a gente não consegue enxergá-las na mesma categoria, embora sejam todas drogas, todas danosas. E os pacientes têm muito essa diferença. Inclusive, os pacientes têm uma gradação entre as drogas, acho que rola essa diferença entre quem usa droga também. Então: “Ah não, eu não uso crack, eu uso só maconha”, ou: “Eu não uso crack, eu uso só cocaína”. Então acho que só quem usa crack é que está ferrado e não tem para onde fugir. Mas sem dúvida tem o preconceito.

Pesquisadora - A próxima pergunta que eu ia te fazer é se dentre as ilícitas existe um preconceito em relação ao usuário de crack. 
E13 - Sem dúvida, o usuário de crack é o fundo do poço, é o noia. E os pacientes que não usam crack fazem muita questão de deixar muito claro que eles não se misturam. Existe muita marginalização mesmo com o dependente de crack.

Pesquisadora - Você já teve muitos pacientes que relataram algum contato com a polícia ou com o Poder Judiciário?

E13 - Mais no PROAD do que no consultório particular. Muito mais no PROAD que no consultório particular.

Pesquisadora - E, geralmente, vem como esse relato, no sentido de uma aproximação que ensejou uma reflexão, que teve algum efeito positivo, que reforçou algum tipo de vínculo, teve uma responsabilização positiva ou num sentido de agressão, ofensa, um ponto mais negativo, na verdade?

E13 - Olha, eu não sei se tem um viés da minha memória, porque os casos que me marcaram foram os casos em que houve um contato negativo. Então eu lembro muito de pacientes que foram presos por conta do uso ou por conta de crimes associados ao uso, roubou para usar, estuprou porque estava sob efeito, que é uma coisa questionável, mas enfim, sempre de forma muito negativa. E tem alguns pacientes que eu tenho essa imagem muito marcante, de terem passado pela polícia, de terem sido presos, e terem uma história de várias idas e vindas nesse contato com a polícia sempre de forma muito negativa.

Eu sei que para todos os pacientes no PROAD a gente pergunta se eles já tiveram algum tipo de contato com a polícia no momento que ele chega. Eu sei que muitos pacientes dizem que sim, mas me parece que fica numa... A gente não aprofunda em como é que foi esse contato nessa primeira entrevista. E pelo menos nessa primeira entrevista fica a impressão de ser uma coisa um pouco neutra.

Contato positivo eu nunca vi de verdade, eu nunca vi.

Pesquisadora - Você acha que a possibilidade de existir um primeiro contato Estadousuário de uma forma repressiva pode afastar esse usuário dos lugares de atenção, de tratamento? Você acredita numa primeira abordagem repressiva que pode motivar a buscar a melhora?

E13 - Não, eu não acho que motiva buscar a melhora, acho que não tem nenhum efeito, a repressão eu acho que não motiva ninguém a buscar tratamento, acho que ter passagem pela polícia, ter sido preso, ter tido contato com polícia, ter sido pego na blitz da Lei Seca, acho que nada disso motiva ninguém a buscar tratamento, pelo menos eu nunca vi ninguém que buscou tratamento por esses motivos. Mas eu não acho que dificulta o acesso ao tratamento, 
eu acho que os pacientes têm uma coisa muito separada de que, embora eu tenha uma experiência grande num serviço que é do Estado, que atende pelo SUS, acho que os pacientes conseguem dividir isso de que a polícia é um agente do Estado, a saúde é outro agente do Estado, e os médicos são legais e os policiais são do mal.

Existe, como eu falei, o estigma dos profissionais de saúde, acho que uma vez que eles conseguem vencer isso eles encontram um bom atendimento e acabam vendo que aquela imagem é errada. Mas eu não acho que porque o policial é do mal ele associe o médico que trabalha no SUS, que também é do Estado, não vai ser legal ou vai ser repressor ou vai espantá-lo do tratamento. Eu acho que a ação repressiva não influencia na busca pelo tratamento, mas tem um viés do fato de que o nosso tratamento, ele é voluntário, então talvez os pacientes que buscam tratamento, pelo contato repressivo eles acabem indo parar em lugares de tratamento involuntário, até porque aquilo não motivou, mas eles estão indo obrigados, a gente está localizado numa região de classe média alta de São Paulo, o PROAD e o meu consultório ficam em bairros de classe média alta de São Paulo, na Vila Mariana e no Paraíso. A gente não acessa os usuários mais graves, eu não faço nenhum trabalho na rua, então assim, as pessoas que chegam são as pessoas que já venceram uma série de barreiras, então talvez o cara que fique afastado do tratamento por conta da ação repressiva da polícia esteja lá na rua e eu não tenha contato com ele.

Pesquisadora - E, para finalizar, qual é a tua opinião sobre uma política que mantém a criminalização do usuário, você acredita que o usuário deva também ser encarado como um criminoso?

E13 - Não. Eu acho que a questão das drogas, para a gente poder avançar, ela precisa sair da esfera da segurança, da esfera criminal, e ela precisa ser encarada cada vez mais como um problema de saúde e de assistência social. Acho que as pessoas que já estão em uso, elas precisam de um tratamento, elas precisam de um tratamento bastante complexo, bastante amplo, e que precisa de uma equipe de profissionais e de uma estrutura física bastante complexa de ser montada, de ser azeitada, um treinamento que é muito longo, e eu acho que a gente só consegue fazer prevenção se a gente conseguir pensar numa reintegração dessas pessoas na sociedade. Isso acho que é o ponto final do tratamento, reintegrar essas pessoas na sociedade, e acho que a prevenção também caminha por aí, acho que a gente precisa, para evitar que novas pessoas entrem numa relação de dependência com a droga, a gente precisa oferecer alternativas para que a droga não seja a única alternativa na vida delas. E aí oferecer moradia, trabalho, enfim, condições de lazer, acho que a gente precisa dar para essas pessoas 
autonomia para que elas consigam levar suas vidas. E acho que hoje a gente sabe que o problema das drogas não está só nas classes sociais desfavorecidas, mas eu acho que essa questão da assistência social, ela é mais ampla, ela passa pela questão da autonomia na vida, de ter escolhas na vida. E que a minha única escolha de vida não seja ter o carro da moda, o celular da moda, e ser o melhor aluno da classe, mas que eu possa ter um trabalho amplo de ter escolhas, de poder fazer da minha vida o que eu quero com ela, que eu não tenha o destino pré-determinado que seja ele de ser o traficante ou de ser o futuro empresário da firma do meu pai, eu acho que é conseguir abrir os horizontes das pessoas.

Pesquisadora - Está bom, obrigada.

E13 - De nada. 


\section{ENTREVISTADO: E14}

Arquivo de Áudio:131017_001

Tempo: 00:10:16

Pesquisadora - Fala para mim, por favor, o seu nome completo.

E14 - [nome].

Pesquisadora - Qual é a sua profissão?

E14 - Enfermeira.

Pesquisadora - E você trabalha com dependente químico desde quando?

E14 - Desde outubro de 2010.

Pesquisadora - E todo esse tempo no PROAD?

E14 - Todo esse tempo no PROAD.

Pesquisadora - $\mathrm{O}$ que você faz aqui no PROAD?

E14 - Eu atendo em grupo de acolhimento, faço atendimentos individuais e faço triagem também.

Pesquisadora - Por essa sua experiência, acho que mais nos grupos e na triagem, na triagem é importante, você acha que existem fatores que você pode considerar comuns para que a pessoa busque o tratamento?

E14 - Então, geralmente, como o PROAD é um serviço que só recebe pacientes voluntariamente, geralmente é quando eles percebem prejuízos na vida, alguma perda, ou perda de emprego ou a perda de um relacionamento, com a família, quando eles começam a ver que estão tendo perdas eles geralmente procuram.

Pesquisadora - E você acha que quando eles interrompem o tratamento eles interrompem por quê?

E14 - Alguns interrompem por recaída, eles recaem e ficam com vergonha de voltar, eles acham que não têm jeito mesmo, que eles não vão conseguir parar. Outros param, abandonam, porque vieram por pressão de familiar e aí, apesar de terem chegado sozinhos e terem o discurso de que "Não, vim buscar porque eu quis" e tudo, a gente sabe que tem uma questão familiar que também interfere bastante e aí eles costumam abandonar o tratamento. Pesquisadora - Essa vergonha que você falou deles recaírem e sentir uma vergonha, você acha que o usuário sente vergonha por ser usuário? 
E14 - Não sentem vergonha por serem usuários, mas por voltar ao serviço para dizer que recaiu. A maioria dos serviços fala muito em abstinência total, e aí quando eles chegam aqui no PROAD a gente explica, principalmente no momento da triagem, que nós não vamos cobrar abstinência total agora, que a gente vai trabalhar o caso a caso, de acordo com o que cada um for trazendo de objetivo a gente vai trabalhar. Só que quando eles recaem, não são todos, mas quando eles recaem e somem eles quando voltam falam: “Ah, eu recaí e fiquei com vergonha de voltar e falar no grupo que eu tinha recaído porque fazia tanto tempo que eu estava sem usar", e isso acontece. Não é vergonha de ser usuário, é vergonha, às vezes, dos colegas que estão, das pessoas que estão no grupo, dos profissionais.

Pesquisadora - Você acha que existem alguns fatores que funcionam como uma espécie de bloqueio para a procura pelo tratamento?

E14 - Olha, não sei se é bloqueio para procurar tratamento, mas existe uma resistência principalmente quando vêm por obrigação, quando alguém está obrigando. Já recebemos aqui pacientes que vieram enganados, vieram trazidos por um familiar, o familiar não disse do que se tratava, chegou aqui e viu na porta, está escrito que é um programa para dependência química, e aí a pessoa começa a ficar incomodada e quando entra na sala para fazer a triagem a gente geralmente chama a pessoa sozinha e faz toda uma explicação do que é o serviço, quais os objetivos, a finalidade, e aí a pessoa ali fala que não, que não é para isso que ela veio aqui. Alguns dizem que veio porque a esposa trouxe para passar no psicólogo, ou a esposa trouxe para passar no médico por conta de uma agressividade em casa, de um relacionamento que não está muito legal, mas não fala que é por conta do uso da substância. E aí a pessoa chega aqui, a gente explica e ele se sente enganado. E isso é um fator que atrapalha bastante e alguns vão embora. Outros ficam, eles falam: "Não, já estou aqui mesmo então vamos fazer". Mas tem alguns que vão embora.

Pesquisadora - Entendi. Você acha que os usuários se sentem diferentes das outras pessoas por serem usuários, você acha que pesa sobre eles algum estigma?

E14 - Acho. Acho, ele próprios falam, eles dizem que o simples fato de estar na rua e de buscar a droga, eles estão se expondo. Às vezes eles falam que mesmo que eles não estejam usando, mas se estiverem acompanhados das pessoas ou estiverem num lugar mais ermo, que passe a polícia, eles falam bastante isso, que se sentem... Como é que fala? Se sentem pressionados de alguma forma, que a polícia aborda com um pouco mais de agressividade, que às vezes está só usando, porque tem diferença, eles falam que se estiver na rua com um 
papelote de droga a polícia vai parar e vai agir de forma diferente, vai ser mais agressiva. Eles falam isso.

Pesquisadora - Eu vou te perguntar mais sobre esses relatos, mas você acha que entre os usuários, os dependentes, e aí a relação com a polícia tem um pouco a ver com isso, existe o preconceito do dependente de droga lícita em relação ao dependente de droga ilícita?

E14 - Acho. O dependente de droga lícita não se expõe tanto a risco para conseguir a substância, ele pode ficar em lugares mais seguros, vamos dizer assim, e o dependente de droga ilícita não, ele é tido como criminoso. E quando ele é tido como criminoso é um outro olhar, é uma outra abordagem, eles relatam bastante isso.

Pesquisadora - E esse outro olhar, essa outra abordagem, você entende como positiva?

E14 - Não.

Pesquisadora - Por que não?

E14 - Porque quando a gente está falando que a pessoa faz uso de substâncias, se tornou um dependente e de alguma forma está buscando ajuda ou ele não está buscando ajuda, tudo vai de uma escolha que ele faz. Isso é do meu ponto de vista, se a polícia atua de forma agressiva ela não vai ajudar, ela só está piorando a situação. As pessoas que chegam aqui que contam que já passaram por sistema prisional, que já foram abordadas por polícia na rua, eles falam bastante dessa agressividade, falam que sentem uma raiva muito grande e que a vontade de revidar é muito importante, e que essa raiva que é gerada faz eles buscarem mais substância porque é uma coisa que de alguma forma faz eles esquecerem um pouco do que acontece.

Pesquisadora - Entendi. Então um abuso, uma situação desagradável, ao invés de ensejar uma reflexão para cessar...

E14 - Isso, piora. Faz ir buscar mais.

Pesquisadora - E aí, partindo disso, você acha que essa política que mantém o usuário na condição de criminoso, ela é positiva?

E14 - Não. Se a gente fala que existe uma doença que a gente trata, aqui no PROAD a gente trata a dependência química, como uma doença. Por que é que a gente tem que tratar a doença como um crime? São duas coisas que não caminham juntas, não tem condições de você dizer que uma pessoa que é doente ao mesmo tempo é um criminoso. Então, para mim, isso é contraditório. Ou você trata como doença e oferece o sistema de saúde para recuperar essas pessoas de forma adequada, ou você trata como criminoso. E aí está todo mundo dentro do mesmo saco de gatos. 
Pesquisadora - E entre os usuários das ilícitas você acha que existe um preconceito em relação ao usuário de crack?

E14 - Então, na verdade não apareceu para mim especificamente a questão do crack. Aparece para mim a diferenciação entre usuário de drogas lícitas e de drogas ilícitas, a gente, quando aborda nos grupos, quando aborda o paciente no atendimento individual ou qualquer que seja, a gente não foca nessa substância, entendeu? Então a gente fala bastante de quais as substâncias que ele está usando, se é lícita ou ilícita, e o que é que a gente vai fazer para ajudá-los ou a reduzir ou a parar, de acordo com o objetivo de cada um.

Pesquisadora - E pensando no usuário específico de crack, se você conseguiu lembrar de alguns, qual você acha que é uma abordagem interessante como um primeiro contato com o usuário de crack, uma abordagem de acolhimento ou uma abordagem mais incisiva?

E14 - Aqui no PROAD a gente sempre faz uma abordagem de acolhimento, sempre explicando que o tratamento é do paciente, que as decisões são dele, que nós estamos aqui para ajudá-lo de acordo com os objetivos dele, se ele vai querer parar, se ele vai querer diminuir, o que é que ele vai querer fazer, e dar para ele segurança, a gente também explica que a gente não emite relatório, a gente não fala do tratamento dele para ninguém, a menos que ele permita, que ele esteja presente. Isso tudo são coisas que além de acolher transmite segurança, porque essas pessoas vêm com bastante receio em relação a isso: "E se algum dia eu for preso e o juiz pedir relatório?”. A gente só emite um relatório dizendo se ele está ou não frequentando, mesmo para um juiz, é isso que o PROAD faz. Eu acho que isso ajuda na aderência ao tratamento.

Pesquisadora - Entendi. É isso, obrigada. 


\section{ENTREVISTADO: E15}

Arquivo de Áudio:131022_001

Tempo: 00:12:38

Pesquisadora - Fala pra mim seu nome completo.

E15 - [nome]

Pesquisadora - Qual é a sua especialidade?

E15 - Eu sou psiquiatra.

Pesquisadora - E você trabalha com usuário de drogas há quanto tempo?

E15 - Trabalho há 27 anos.

Pesquisadora - Sempre no PROAD ou em outros lugares?

E15 - Eu trabalhei antes do PROAD alguns meses num estágio que eu fiz na França. Não, faz mais do que isso porque antes eu trabalhava com dependente químico no Pronto Socorro, então faz uns 30 anos. Trabalhei um pouco no Pronto Socorro da Universidade Federal de São Paulo, depois fui fazer estágio na França e trabalhei lá também, daí eu vim e montei o PROAD há 26 anos atrás.

Pesquisadora - E o PROAD é um pouco inspirado nessa experiência francesa?

E15 - Totalmente.

Pesquisadora - Como chama o...

E15 - Centre Médical Marmottan.

Pesquisadora - Pela sua experiência você acha que tem algum fator que você possa dizer que é recorrente para que o usuário busque o tratamento? Alguma experiência que eles trazem de forma recorrente: "Ah, eu procurei ajuda por isso".

E15 - Você diz o usuário?

Pesquisadora - É.

E15 - Eu acho que o usuário pede ajuda quando ele percebe que ele está perdendo o controle da sua relação com o produto, com a droga.

Pesquisadora - E aí o perder o controle tem estágios de perda de controle? Porque eu imagino que nem todo mundo procure o tratamento na primeira vez que sente uma dificuldade na relação. 
E15 - Isso é muito variável, de pessoa para pessoa, tem gente que perde o controle e demora para perceber que perdeu o controle. Então a autopercepção nem sempre acompanha o andamento de um processo de dependência. Porque se a gente for ver a maioria dos usuários de drogas, sejam drogas lícitas ou ilícitas, estou incluindo o álcool como droga, a maioria dos usuários não se torna dependente. Isso é válido para cocaína e até para crack, para a maconha. E a minoria que se torna dependente justamente é essa minoria que perdeu o controle do seu uso, seja em termos de quantidade, de frequência, e acaba comprometendo a vida do indivíduo, ele acaba tendo dificuldades de trabalhar, de estudar, de manter relacionamentos interpessoais, seriam essas as características, essas consequências dessa perda de controle.

Não sei se eu te respondi ou fugi do tema.

Pesquisadora - Não, não, respondeu. Na verdade eu vou fazendo outras e daqui a pouco eu vou chegar nos meus pontos mais sensíveis.

Você acha que existe um preconceito... Primeiro, na verdade, você acha que os usuários se sentem diminuídos em relação às outras... Eu falo dos usuários dependentes, com uma situação mais problemática com a droga, se sentem diferentes das outras pessoas por serem usuários, eles sentem que existe um preconceito contra eles?

E15 - Sim, a maioria sente. Porque eu acho que a nossa sociedade vê isso, em grande parte, como um problema moral. Uma falta de autodeterminação ou de controle, na verdade é uma falta de controle, mas sem essa questão pejorativa porque eu entendo, enquanto médico, que a doença é justamente isso: a perda de controle. Então eu não vejo sob o ponto de vista moralista, o indivíduo que não foi forte o suficiente, que não resistiu. Eu acho que essa é uma visão muito, vamos dizer assim, "religiosa".

Pesquisadora - E você acha que dentre os usuários existe o preconceito entre os usuários de drogas lícitas em relação aos usuários de drogas ilícitas?

E15 - Muito claramente. O pessoal que é dependente de álcool acha que está muito melhor do que os dependentes de drogas ilícitas e, inclusive, eles olham de uma forma preconceituosa, como se aquilo fosse uma coisa horrível e o deles não, o deles é uma coisa mais aceitável pelo status de legalidade da droga.

Pesquisadora - E dentre os usuários de ilícitas você acha que existe ainda um preconceito em relação ao usuário de crack?

E15 - Existe. Eu já vi vários usuários, dependentes de cocaína, acharem que o pessoal que é dependente de crack é o fim da linha, uma conotação muito pejorativa mesmo. 
Pesquisadora - E por que você acha que isso acontece em relação ao usuário de crack? A propaganda em relação a essa forma de uso da cocaína pode contribuir para esse jeito como eles são vistos?

E15 - A propaganda do que?

Pesquisadora - A propaganda em relação ao crack, a propaganda do governo, a mídia como trata...

E15 - Ah, sim, eu acho que sim. Eu acho que existe, por exemplo, a mídia faz com que a população associe o crack à situação de vulnerabilidade social, às cracolândias, à situação de indigência, à miséria social mesmo. Então fica muito associado o crack a essa situação, quando a gente sabe que tem pessoas de outro nível também que são dependentes de crack, só atualmente tem 3 médicos aqui que são dependentes de crack, meus pacientes. E são pessoas que têm filhos, têm família, têm emprego. Não que eles estejam bem, eles não estão bem, mas não tem nada a ver com aquela situação da cracolândia. Então eu acho que é por conta de preconceito mesmo.

Pesquisadora - E essa forma como o crack é divulgado, você acha que pode ser um dificultador no acesso ao tratamento, que as pessoas podem, eventualmente, não procurar por terem vergonha?

E15 - Nunca parei para pensar nisso. Em tese talvez fosse possível que isso acontecesse. A gente vê isso muito em população feminina, as mulheres têm muito mais dificuldade de procurar ajuda, os homens assumem mais facilmente a dependência, as mulheres se sentem muito inferiorizadas por estarem dependentes de alguma coisa, é um fenômeno mais feminista ou machista aí, eu não sei. Mas talvez exista isso também da pessoa não querer ser identificada com aquela população excluída de cracolândia.

Pesquisadora - É comum que os pacientes, e aí eu te peço para pensar um pouco mais nos pacientes de crack só porque eu restringi o estudo a eles, é comum que eles tragam algum relato de contato com a polícia?

E15 - Frequente, muito frequente. Mas isso está mais relacionado com as populações mais desfavorecidas. Porque o pessoal de população mais favorecida, eles têm mecanismos de controle disso. E o pessoal que está nessa situação de cracolância, que é uma situação de muita visibilidade, muita vitrine, eles estão expostos, eles ficam mais vulneráveis a isso.

Pesquisadora - E os relatos de contato com a polícia geralmente são positivos ou negativos? E15 - Muito negativos, é de agressão, de violência. 
Pesquisadora - E você pensa... Esse contexto de violência, uma eventual primeira abordagem violenta, você pensa que pode afastar o usuário do sistema de saúde, pode de alguma forma agravar o uso por uma situação traumática?

E15 - Pode não, ele faz isso, a gente percebe. Toda vez que a gente vai fazer um trabalho em campo, eu já fui várias vezes fazer trabalho em campo, o agente, enquanto autoridades, eles não sabem bem quem essa pessoa que está chegando e ele sempre olha com muita desconfiança, achando que a gente vai de novo ser um agressor, um repressor, e até eles adquirirem uma confiança isso demora um tempo.

Pesquisadora - Então essa possibilidade de um primeiro contato feito pela polícia, que é essencialmente repressivo, de repente pode gerar uma desconfiança por parte do usuário em relação ao Estado, à figura do poder.

E15 - Seguramente, eles vêm o Estado como um elemento de punição, de agressão, de violência e não de cuidado.

Pesquisadora - Qual é a sua opinião sobre uma política que mantém criminalizado o usuário de drogas, só a criminalização do uso, que insere o usuário no sistema criminal?

E15 - Eu acho um absurdo, eu acho que é uma coisa medieval. Eu acho que a gente já está atrasado, mesmo, por exemplo, eu lembro quando eu morava na França há quase 30 anos atrás, e a França não é um país que é muito ousado em políticas na área de drogas, mas como é um país que é muito civilizado, eu lembro que, por exemplo, quando eu morava lá, se eu policial chegasse e encontrasse um garoto, um adolescente fumando maconha na rua, embora ele pudesse até prender ou autuar, ter alguma medida repressiva, não, a atitude do policial era ir lá e dar uma bronca, falar: "Ô, menino, para com isso. Você vai ficar doente, vai se matar.", ou seja, ele dava uma bronca como se fosse um pai dando uma bronca num filho, não num ato de violência. E isso num país que não tem nada de progressista em termos de política de drogas. E isso há 30 anos atrás. Então a gente vê que existe uma tendência do mundo de fazer isso mesmo informalmente, quando não existe uma política pública sustentando, por uma questão de bom senso. Mesmo Estados Unidos que é um país que tradicionalmente lançou a guerra às drogas, tinha uma visão muito maniqueísta, muito retrógrada, hoje em dia a gente tem dois Estados lá com a liberação da maconha, tem 19 Estados com liberação de maconha medicinal, então a gente vê essa... Canadá, Austrália, Espanha. Portugal tem a política portuguesa, ou seja, o mundo todo está caminhando no sentido de descriminalizar o usuário mesmo, o uso, descriminalizar o uso e despenalizar o usuário. Não sei se a terminologia jurídica é essa, mas... 
Então a gente está na contramão da História, a gente ainda confunde tudo.

Pesquisadora - Eu não posso direcionar, eu fico pensando as coisas...

E15 - Não pode mesmo, Tese não pode. Faça a pergunta neutra.

Pesquisadora - Estou tentando, mas é difícil. Deixa eu lembrar. Você pensa que, de alguma forma, um contato repressivo em relação ao uso pode viabilizar uma reflexão sobre a necessidade de procurar ajuda?

E15 - Não. Eu acho que isso não ocorre, mas eu vou abrir um parêntese aí: tem uma situação, que é quando o indivíduo perdeu a capacidade de autodeterminação. É onde a única situação onde se estaria justificada, por exemplo, uma internação involuntária. Mas isso é muito bem estabelecido na psiquiatria, são situações em que o indivíduo está psicótico, ou seja, fora da realidade, ou às vezes não está totalmente psicótico, mas ele tem um alto risco de suicídio. Então, são situações de exceção onde você está autorizado a usar de um método mais incisivo, mais agressivo, que seria uma internação involuntária, até o indivíduo recuperar essa capacidade de autodeterminação. Mas, atenção, essas internações involuntária, elas são, por definição, internações de curta duração, de 15 dias, um mês no máximo. Passando disso já não se justifica essa medida. É só para tirar o indivíduo do olho do furacão, na hora de uma crise em que o indivíduo perdeu essa capacidade de autodeterminação. Porque você não ter o controle do uso de drogas não é perda da capacidade de autodeterminação, é uma coisa muito específica direcionada ao consumo de um produto. Tanto que tem pessoas que usam droga, às vezes usam de maneira compulsiva, e conseguem manter trabalho, família e a vida normal.

Pesquisadora - É isso, obrigada.

E15 - Só isso?

Pesquisadora - Só.

E15 - Eu achei que era uma coisa imensa.

Pesquisadora - Não... 


\section{ENTREVISTADO: E16}

Arquivo de Áudio:131022_002

Tempo: 00:14:41

Pesquisadora - Me fala seu nome completo, por favor.

E16 - [nome]

Pesquisadora - Qual é a sua especialidade?

E16 -Psiquiatria.

Pesquisadora - Você trabalha com usuário de drogas há quanto tempo?

E16 - Contando com formação e residência médica quatro anos, mas como profissional mesmo, psiquiatra, especialista, um ano.

Pesquisadora - E sempre trabalhou aqui no PROAD?

E16 - Sempre.

Pesquisadora - Hoje em dia qual é a sua atividade aqui?

E16 - Como supervisor e médico, atendo pacientes.

Pesquisadora - Atendimentos individuais?

E16 - Atendimentos individuais.

Pesquisadora - Eu vou fazer perguntas e você pode pensar aos olhos de drogas em geral, mas de vez em quando eu vou te pedir para pensar um pouco no usuário de crack que é a amostra, então se der para enviesar o pensamento nesse sentido é bom.

Quando os usuários vêm procurar tratamento você pode me dizer que existe algum fator que aparece de forma recorrente como ensejador dessa busca? Então: "Eu estou aqui procurando um tratamento por isso", e aí tem uma similaridade entre muitos casos?

E16 - Geralmente os pacientes que procuram o PROAD ou outros serviços onde eu trabalho também com dependentes eles já buscam depois de um longo período já de uso, geralmente já muito intenso e abusivo, que acaba começando a trazer muitos prejuízos. O mais comum acho que é a parte social, a família, muitos já começam a ficar em situação de rua, ou então já um longo período desempregado, não conseguem pegar nenhum emprego mais, e aí começa a ter alguns casos, alguns comorbidades clínicas, fazem então com que eles realmente percebam que está na hora de parar e aí buscam tratamento.

Pesquisadora - E você acha que existe algum fator que seja recorrente para o abandono do tratamento? 
E16 - Acho que aí também vai a questão social. Primeiro porque muitos já estão em situação de rua, já fica o contato intenso com outros usuários. A maioria me fala que não consegue manter a abstinência de forma sustentável, principalmente por conta de não conseguir dizer não aos colegas que ficam oferecendo a substância, e muito também por conta de todas essas adversidades eles acabam usando a substância como uma forma de alívio, de fuga.

Pesquisadora - Eu vou continuar, pelo que você falou, para dois caminhos, primeiro para um e depois para outro. Quando você falou da dificuldade de dizer não, pelos amigos, que eles acabam tendo um círculo, você acha que o fato de que eles passam a conviver só com esse círculo da droga é um dificultador? Porque, de repente, eles não têm outros vínculos onde se agarrar?

E16 - Sim, com certeza. Existem vários dispositivos, que não somente de área da saúde, mas, inclusive albergues, essa parte de assistência social, onde eles podem buscar ajuda, mas muitos deles já procuraram ou nunca procuraram, mas se recusam a procurar esses tipos de serviços, acabam ficando só nesse pequeno círculo social, e com esse convívio tão próximo com a substância fica difícil se distanciar deles, porque é o último vínculo que tem. Tem até um colega meu que já trabalhou [ininteligível], mas já trabalhou com a população de rua de dependentes químicos na região do $\mathrm{ABC}$ e ele me falou como é contrastante, por exemplo, com o pessoal de São Cateano, que a população, as ruas, são bem mais bonitas, teve um investimento maciço nessa área. E aí a população de rua não consegue se identificar com o ambiente, com as pessoas, os prédios, as coisas mais bonitas, e acabam migrando para outras regiões que eles se identificam mais: pessoas, moradores também em situação de ruas, que as pessoas se identificam e acabam sempre ficando nesse círculo, não conseguem sair.

Pesquisadora - E você acha que o usuário, na esfera que você está falando, se sentem mesmo diferentes das outras pessoas?

E16 - Para mim, acho que eles se sentem. Na verdade, eu nunca perguntei isso para nenhum paciente meu, mas acredito que eles se sintam porque eles ficam privados de muitas coisas, coisas que para a gente é tão simples e habitual. Um simples banho, que para a gente é a coisa mais natural, para eles não é. Em algum lugar ou outro eles conseguem, depois de juntar dinheiro pedindo esmola ou catando latas de refrigerante, aí eles conseguem juntar esse dinheirinho e pagar por um banho, mas é uma coisa pontual. Então [ininteligível] bem diferentes.

Pesquisadora - E você consegue perceber a existência de algum tipo de preconceito entre os usuários de drogas lícitas para os usuários de drogas ilícitas? 
E16 - Eu acho que... Me faz pensar sim. Porque pacientes usuários de crack, muitos deles, já têm prejuízos mais graves, eles já estão mais marginalizados da sociedade. Enquanto que pacientes dependentes de substâncias lícitas não. Exceto pelos casos mais extremos, mais graves, de substâncias lícitas, principalmente o álcool, que aí sim geralmente estão tão marginalizados quanto os usuários de crack.

Pesquisadora - Você acha que essa estigmatização prejudica na adesãoao tratamento, a gente começou falando disso...

E16 - A questão de condução, mesmo a gente conseguindo para alguns pacientes isenção tarifária para ônibus muitos deles acabam vendendo, tem até nas ruas alguns lugares em que você vê placas falando "Compra-se passes de ônibus", eles acabam trocando isso por dinheiro para depois trocar por substâncias. Então a questão de transporte é já é uma coisa que pega bastante. Considerando São Paulo que é gigante fica mais complicado.

A questão de moradia fixa, muitos deles acabam transitando em várias regiões diferentes, então tendo o CAPS, por exemplo, o modo de atendimento que é o CAPS, que são mais regionalizados, então são pacientes que acabam não conseguindo acesso a um serviço, é aquele serviço, então até transportar para outro, nunca vai tendo um acompanhamento nesse serviço.

Pesquisadora - Entendi. E agora vou partir para a outra pergunta sobre o que você falou, você disse que às vezes eles passam por tantas privações e por tantas dificuldades que a substancia acaba sendo uma fuga. E aí você acha que o vivenciar experiências traumáticas, violentas, pode, de repente, propiciar um aumento nesse uso? Pela repetição de situações desagradáveis.

E16 - Sim, eu acredito que sim. Está muito comum, isso já tendendo para doenças psiquiátricas, é muito comum junto com a dependência de substâncias tanto lícitas quanto ilícitas a alta prevalência de outras doenças psiquiátricas, [ininteligível] psiquiátricas, o conjunto. E aí fica difícil dizer se foi a [ininteligível] psiquiátrica que induziu ao uso de substâncias ou se foi o inverso. Mas a verdade é que existe uma alta percentagem, uma alta prevalência dessa [ininteligível]. Varia muito na literatura, chega até, das mais [ininteligível] $80 \%$, mas eu acho que já é muito, mas acredito que por volta de $50 \%$ devem estar atrelados. Pesquisadora - E aí, pensando nisso também, em experiências traumáticas, como é que você enxerga a política de drogas brasileira que mantém em relação ao usuário uma postura também repressiva? 
E16 - Eu acho isso muito complicado, porque você está trabalhando só uma parte muito pontual e específica do dependente. Isso porque a gente já está falando da pessoa como “dependente”, mas a pessoa em si, são várias coisas, eles são, representam e fazem várias coisas. As drogas podem, nesse caso, estreitar, ter esse estreitamento em função da droga, ficar só voltado à droga, mas a ideia é que sejam trabalhadas várias coisas que às vezes não vai ser possível alcançar só com a parte médica, a parte psicológica, a parte terapêutica ocupacional, mas muitos vão precisar de uma assistência social, uma assistência jurídica, muitos deles têm questões legais, e coisas que para nós pode ser simples de lidar, de resolver o problema, para eles, eles não conseguem dar o pontapé inicial. E aí, se tivessem investimentos em outras áreas, inclusive de moradia, profissional, já seriam facilitadores para adesão e sucesso no tratamento.

Pesquisadora - Eu ia fazer uma pergunta e perdi aqui... Sabe quando você está pensando? Ah, lembrei. Você falou que muitos deles têm problemas legais, eu queria saber: quando eles trazem, se eles já tiverem trazido, algum relato de contato com polícia, com fórum, o relato é positivo ou é negativo?

E16 - Como assim, positivo ou negativo?

Pesquisadora - Quando o paciente conta alguma história, no geral, é um relato positivo ou um relato negativo? É um relato de "Fui bem tratado, conversei e me deram uma opção" ou foi um relato no sentido de "Fui ofendido, fui humilhado, me senti pior e a situação não foi agradável'?

E16 - Geralmente é negativo, mas muitas vezes eles preferem não entrar em tantos detalhes nesse sentido, mas explicar o que foi, o que aconteceu exatamente, qual foi o problema, mas não entrar em detalhes sobre como eles foram cuidados ou não porque eles já... Eu nunca entrei em detalhes com esse sentido, se foram acuados ou não bem tratados, acho que realmente nunca perguntei isso também, é uma boa pergunta. Eu acho que eles, pelo menos, na consulta médica, eles já imaginam o foco em outra parte. Mesmo porque, geralmente, essa questão legal quem pergunta sou eu, não parte tão naturalmente deles.

Pesquisadora - E você acha que uma política de sucesso deveria prescrever como primeiro contato entre Estado-instituição-usuário um contato repressivo ou um contato acolhedor?

E16 - Acolhedor, com certeza. Acho que não tem nem como justificar, é uma questão óbvia essa. A parte repressiva muitas vezes afastava o usuário do serviço. Tive uma outra experiência, de tratamento fechado, de internação para dependentes químicos, tivemos um problema, a polícia quis entrar à força para reconhecer um paciente e a gente dizer que não 
poderia e mesmo assim entrou e ficou um clima bem difícil, mesmo depois de tudo, do pessoal ter ido embora, deu para perceber que os pacientes ficaram um pouco mais com o pé atrás com toda a equipe.

Pesquisadora - Entendi. A entrada de uma equipe de polícia, na realidade, deixou eles todos ressabiados com toda a equipe médica?

E16 - Exatamente. Toda a equipe...

Pesquisadora - É multidisciplinar?

E16 - Médicos, enfermagem...

Pesquisadora - Curioso isso. Está bom, obrigada. É isso. 


\section{Anexo 1 - Parecer Consubstanciado do CeP}

EM PESQUISA-SMS
SAÚDE DE SÃO PAULO -
SMS/SP

\section{PARECER CONSUBSTANCIADO DO CEP}

\section{DADOS DO PROJETO DE PESQUISA}

Título da Pesquisa: A INFLUÊNCIA DA REPRESSÃO PENAL SOBRE O USUÁRIO DE CRACK NA BUSCA PELO TRATAMENTO

Pesquisador: Gabriela Prioli Della Vedova

Área Temática:

Versão: 2

CAAE: 11637112.0 .0000 .0086

Instituição Proponente:UNIVERSIDADE DE SAO PAULO

Patrocinador Principal: Financiamento Próprio

\section{DADOS DO PARECER}

Número do Parecer: 235.634

Data da Relatoria: 04/04/2013

\section{Apresentação do Projeto:}

Considerando a natureza das medidas impostas aos usuários de drogas, bem como os efeitos tidos como justificadores da aplicação destas medidas, busca-se uma explicação de até que ponto a ameaça de sanção penal e o exercício da repressão penal por meio das ações policiais e do poder judiciário atuam subjetivamente no usuário no que diz respeito à busca por tratamento e sua consequente reintegração social.

Objetivo da Pesquisa:

Por meio de pesquisa qualitativa o objetivo é compreender o que foi construído no contato desses sujeitos com a realidade, nas diferentes interações humanas e sociais.

\section{Avaliação dos Riscos e Benefícios:}

A autora afirma que não há risco ou benefícios diretos ao participante, mas em caso de necessidade os mesmos serão encaminhados ao Programa de Orientação e Atendimento a Dependentes (PROAD), vinculado ao Departamento de Psiquiatria da Escola Paulista de Medicina da Universidade Federal de São Paulo

\section{Comentários e Considerações sobre a Pesquisa:}

O projeto apresenta relevância ao investigar a questão do uso do crack na interface entre o direito e a saúde, em busca dos significados que os participantes atribuem à sua experiência, o que pode

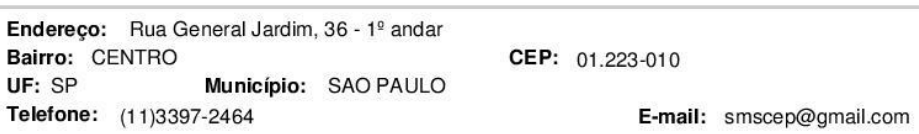




\section{$\underset{\text { EM PESQUUSA-SMS }}{0} \begin{gathered}\text { SECRETARIA MUNICIPAL DA } \\ \text { SAÚDE DE SÃO PAULO - } \\ \text { SMS/SP }\end{gathered}$}

oferecer outras possibilidades de atuação aos profissionais da área do direito, assim como da saúde para lidar com o problema.

Considerações sobre os Termos de apresentação obrigatória:

Os termos de apresentação obrigatória foram complementados.

Recomendações:

Enviar um adendo ao CEP da instituição proponente a fim de que sejam informadas as alterações feitas ao projeto ora aprovado.

Conclusões ou Pendências e Lista de Inadequações:

Havendo a pesquisadora atendido às recomendações do CEP da SMS SP, considero o projeto aprovado

\section{Situação do Parecer:}

Aprovado

\section{Necessita Apreciação da CONEP:}

Não

Considerações Finais a critério do CEP:

Para início da coleta dos dados, o pesquisador deverá se apresentar na mesma instância que autorizou a realização do estudo (Coordenadoria, Supervisão, SMS/Gab, etc).

O sujeito de pesquisa (ou seu representante) e o pesquisador responsável deverão rubricar todas as folhas do Termo de Consentimento Livre e Esclarecido ¿ TCLE apondo sua assinatura na última página do referido Termo, conforme Carta Circular no 003/2011 da CONEP/CNS.

Salientamos que o pesquisador deve desenvolver a pesquisa conforme delineada no protocolo aprovado. Eventuais modificações ou emendas ao protocolo devem ser apresentadas ao CEP de forma clara e sucinta, identificando a parte do protocolo a ser modificada e suas justificativas. Lembramos que esta modificação necessitará de aprovação ética do CEP antes de ser implementada.

Ao pesquisador cabe manter em arquivo, sob sua guarda, por 5 anos, os dados da pesquisa, contendo fichas individuais e todos os demais documentos recomendados pelo CEP (Res. CNS 196/96 item IX. 2. e). De acordo com a Res. CNS 196, IX.2.c, o pesquisador deve apresentar a este CEP/SMS os relatórios semestrais. O relatório final deverá ser enviado através da Plataforma Brasil, ícone Notificação. Uma cópia digital (CD/DVD) do projeto finalizado deverá ser enviada à instância que autorizou a realização do estudo, via correio ou entregue pessoalmente, logo que o mesmo estiver concluído.

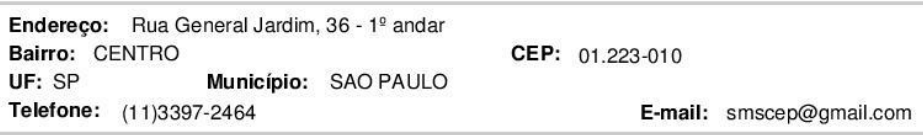




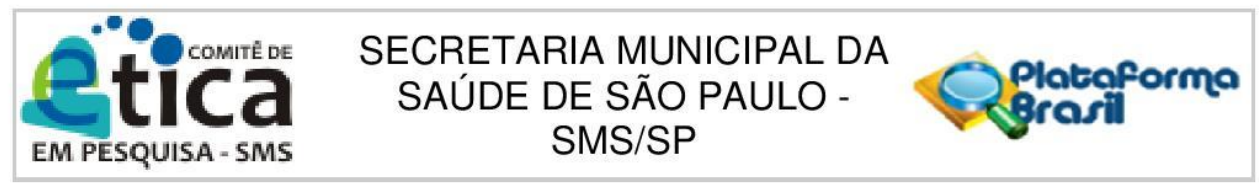

SAO PAULO, 03 de Abril de 2013

Assinador por:

SIMONE MONGELLI DE FANTINI

(Coordenador)

Endereço: Rua General Jardim, $36-1^{\circ}$ andar

Bairro: CENTRO

CEP: $\quad 01.223-010$

UF: SP Município: SAOPAULO

Telefone: (11)3397-2464 